Prepared in cooperation with the Arizona Department of Water Resources

\title{
Hydrology of the Middle San Pedro Watershed, Southeastern Arizona
}
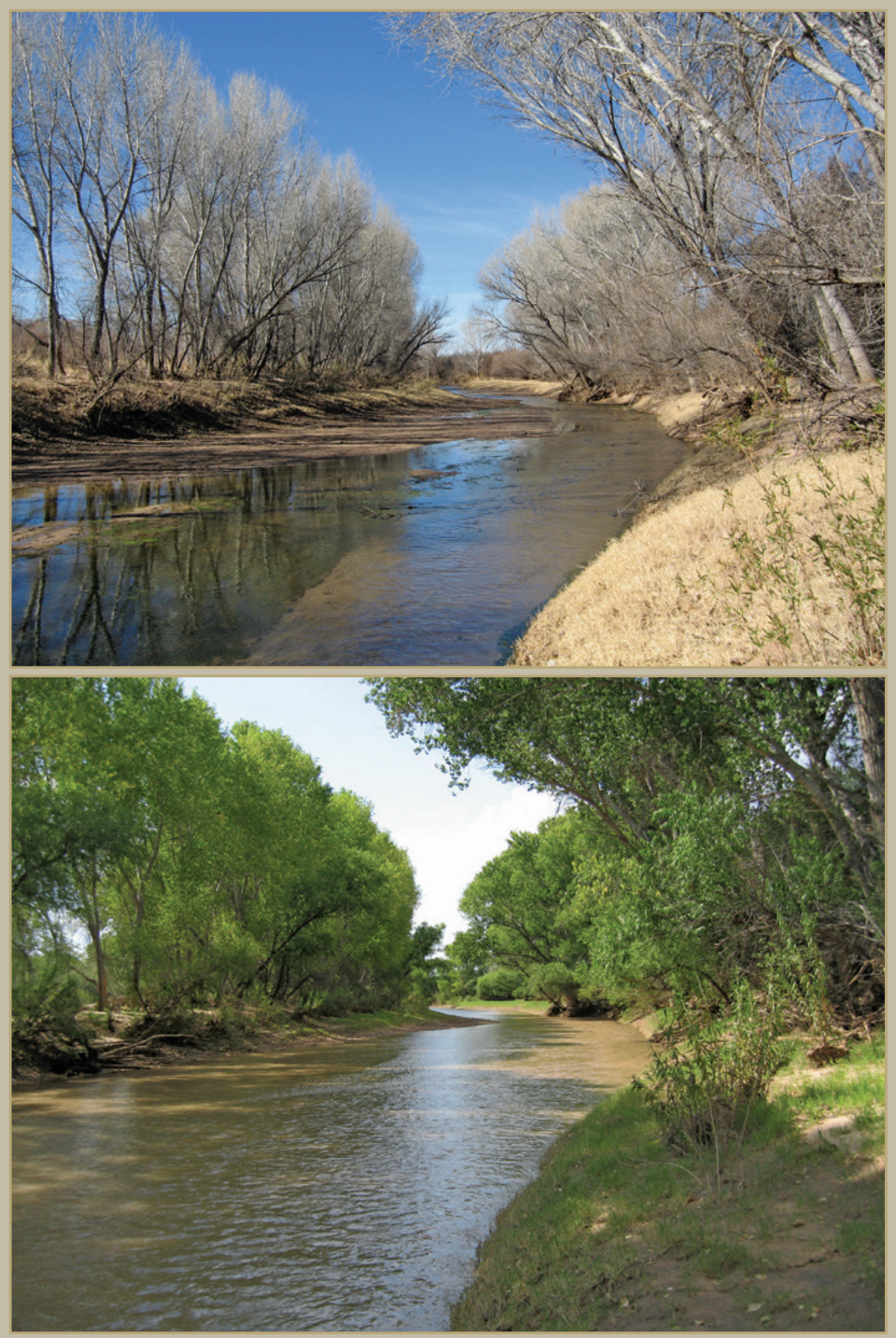

Scientific Investigations Report 2013-5040 
COVER

A reach of the San Pedro River near St. David, Arizona, shown in January 2009 (top) and in August 2008 (bottom). Both photographs by Candice B. Hopkins, U.S. Geological Survey. 


\section{Hydrology of the Middle San Pedro Watershed, Southeastern Arizona}

By Jeffrey T. Cordova, Jesse E. Dickinson, Kimberly R. Beisner, Candice B.

Hopkins, Jeffrey R. Kennedy, D.R. Pool, Edward P. Glenn, Pamela L. Nagler, and Blakemore E. Thomas

Prepared in cooperation with the Arizona Department of Water Resources

Scientific Investigations Report 2013-5040 


\section{U.S. Department of the Interior SALLY JEWELL, Secretary}

\section{U.S. Geological Survey Suzette M. Kimball, Acting Director}

\section{U.S. Geological Survey, Reston, Virginia: 2015}

For product and ordering information:

World Wide Web: http://www.usgs.gov/pubprod

Telephone: 1-888-ASK-USGS

For more information on the USGS—-the Federal source for science about the Earth, its natural and living resources, natural hazards, and the environment:

World Wide Web: http://www.usgs.gov

Telephone: 1-888-ASK-USGS

Any use of trade, product, or firm names is for descriptive purposes only and does not imply endorsement by the U.S. Government.

Although this report is in the public domain, permission must be secured from the individual copyright owners to reproduce any copyrighted material contained within this report.

Suggested citation:

Cordova, J.T., Dickinson, J.E., Beisner, K.R., Hopkins, C.B., Kennedy, J.R., Pool, D.R., Glenn, E.P., Nagler, P.L., and Thomas, B.E., 2015, Hydrology of the middle San Pedro Watershed, southeastern Arizona: U.S. Geological Survey Scientific Investigations Report 2013-5040, 77 p., http://dx.doi.org/10.3133/sir20135040. 


\section{Conversion Factors and Datum}

\begin{tabular}{|c|c|c|}
\hline Multiply & By & To obtain \\
\hline \multicolumn{3}{|c|}{ Length } \\
\hline centimeter $(\mathrm{cm})$ & 0.3937 & inch (in.) \\
\hline millimeter (mm) & 0.03937 & inch (in.) \\
\hline meter $(\mathrm{m})$ & 3.281 & foot $(\mathrm{ft})$ \\
\hline kilometer $(\mathrm{km})$ & 0.6214 & mile (mi) \\
\hline \multicolumn{3}{|c|}{ Area } \\
\hline square meter $\left(\mathrm{m}^{2}\right)$ & 0.0002471 & acre \\
\hline square hectometer $\left(\mathrm{hm}^{2}\right)$ & 2.471 & acre \\
\hline \multicolumn{3}{|c|}{ Volume } \\
\hline cubic meter $\left(\mathrm{m}^{3}\right)$ & 0.0008107 & acre-foot (acre-ft) \\
\hline cubic hectometer $\left(\mathrm{hm}^{3}\right)$ & 810.7 & acre-foot (acre-ft) \\
\hline \multicolumn{3}{|c|}{ Flow rate } \\
\hline cubic meter per year $\left(\mathrm{m}^{3} / \mathrm{yr}\right)$ & 0.0008107 & acre-foot per year (acre-ft/yr) \\
\hline cubic hectometer per year $\left(\mathrm{hm}^{3} / \mathrm{yr}\right)$ & 810.7 & acre-foot per year (acre-ft/yr) \\
\hline cubic meter per day $\left(\mathrm{m}^{3} / \mathrm{d}\right)$ & 35.31 & cubic foot per day $\left(\mathrm{ft}^{3} / \mathrm{d}\right)$ \\
\hline meter per year (m/yr) & 3.281 & foot per year ft/yr) \\
\hline millimeter per year (mm/yr) & 0.03937 & inch per year (in/yr) \\
\hline \multicolumn{3}{|c|}{ Radioactivity } \\
\hline picocurie per liter $(\mathrm{pCi} / \mathrm{L})$ & 0.037 & becquerel per liter $(\mathrm{Bq} / \mathrm{L})$ \\
\hline \multicolumn{3}{|c|}{ Acceleration } \\
\hline microGal $(\mu \mathrm{Gal})$ & 10 & nanometer/second ${ }^{2}\left(\mathrm{~nm} / \mathrm{s}^{2}\right)$ \\
\hline microGal $(\mu \mathrm{Gal})$ & $0.328 \times 10^{-9}$ & feet $/$ second $^{2}\left(\mathrm{ft} / \mathrm{s}^{2}\right)$ \\
\hline
\end{tabular}

Temperature in degrees Celsius $\left({ }^{\circ} \mathrm{C}\right)$ may be converted to degrees Fahrenheit $\left({ }^{\circ} \mathrm{F}\right)$ as follows: ${ }^{\circ} \mathrm{F}=\left(1.8 \times{ }^{\circ} \mathrm{C}\right)+32$

Vertical coordinate information is referenced to the National Geodetic Vertical Datum of 1988 (NGVD 88).

Horizontal coordinate information is referenced to the North American Datum of 1983 (NAD 83).

Elevation, as used in this report, refers to distance above the vertical datum.

Concentrations of chemical constituents in water are given either in milligrams per liter $(\mathrm{mg} / \mathrm{L})$ or micrograms per liter $(\mu \mathrm{g} / \mathrm{L})$. 


\section{Contents}

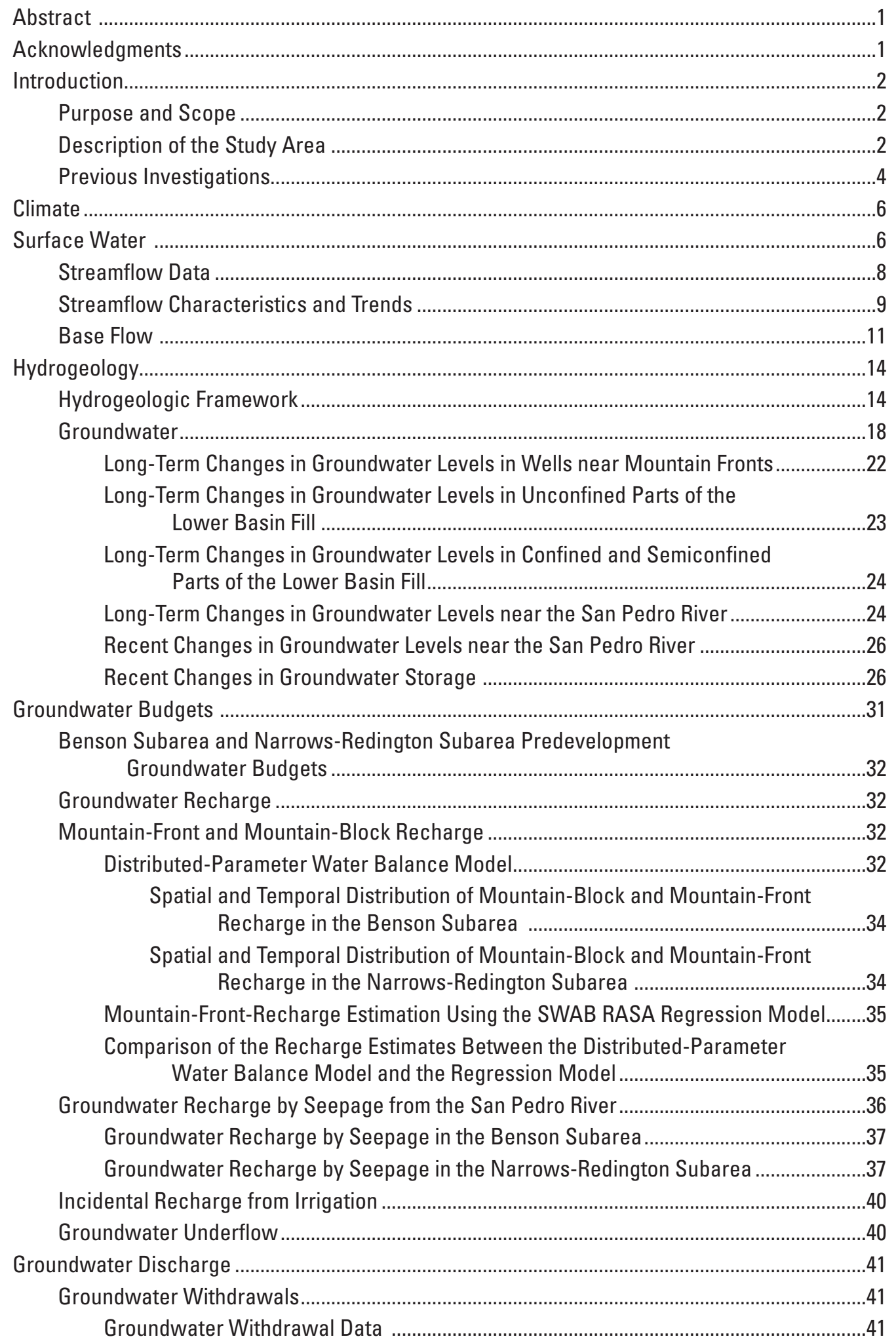




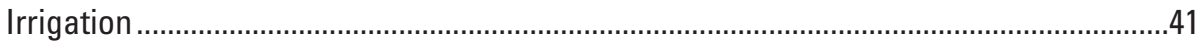

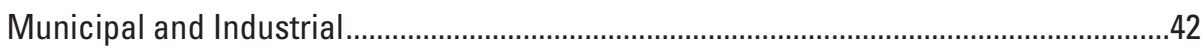

Self-Supplied Domestic Groundwater Withdrawals ...................................................43

Evapotranspiration of Groundwater in Riparian Areas .........................................................4

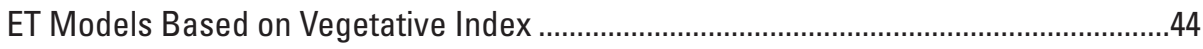

Application of the EVI* ET Model...................................................................................48

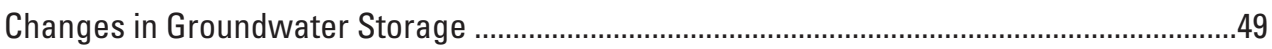

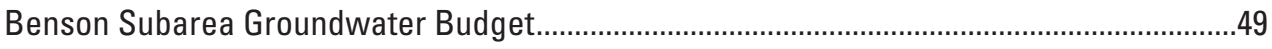

Narrows-Redington Subarea Groundwater Budget...........................................................50

Hydrochemistry and Water Quality......................................................................................5

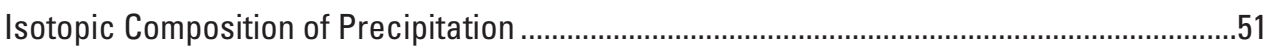

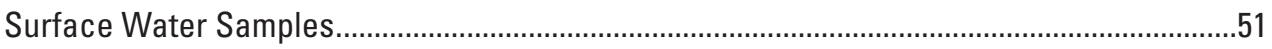

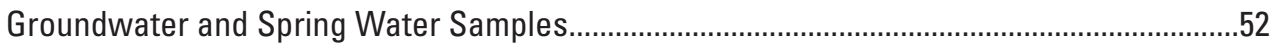

Spatial Variability of Groundwater Chemistry ..................................................................52

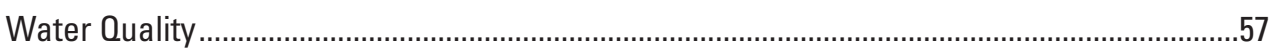

Study Limitations and Considerations for Future Data Collection and Analysis .............................57

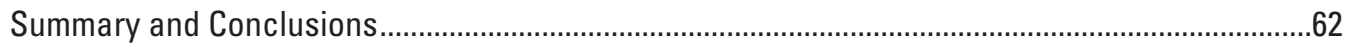

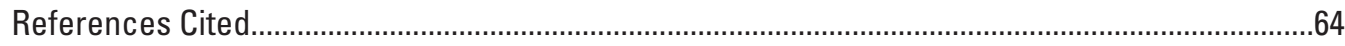

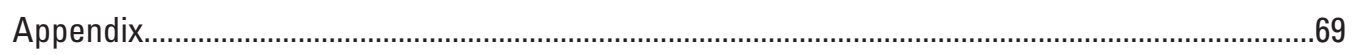

\section{Figures}

1. Map showing the middle San Pedro Watershed in southeastern Arizona ...............................

2. Bar graph showing average monthly precipitation at Tombstone, Arizona, 1913-2009..........6

3. Scatter plots showing annual and seasonal precipitation at Tombstone, Arizona,

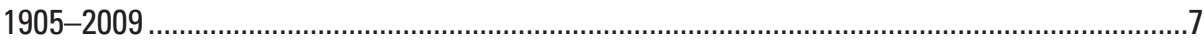

4. Bar graph of annual precipitation at Tombstone, Arizona.......................................................8

5. Scatter plot of annual streamflow of the San Pedro River at Charleston, Arizona .............. 10

6. Bar graph showing annual streamflow ............................................................................11

7. Plot of average daily streamflow throughout the year at gaging stations on the San Pedro River in the middle San Pedro Watershed......................................................12

8. Bar chart of annual peak flows at the Redington and Charleston gaging stations ................13

9. Bar chart of annual base flow at the San Pedro River near Tombstone, Arizona...................14

10. Bar chart of estimated median base flow at the Tombstone, Arizona ..................................15

11. Map showing distribution of surficial hydrogeologic units in the middle San Pedro Watershed.

12. Hydrogeologic cross sections showing distribution of coarse-grained, interbedded, and fine-grained hydrogeologic units in the middle San Pedro Watershed, Arizona ............16

13. Map showing wells in the middle San Pedro Watershed for which lithologic logs

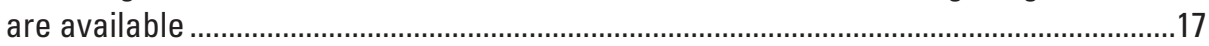

14. Map showing predevelopment water-level contours in $1940 \ldots \ldots \ldots \ldots \ldots \ldots \ldots \ldots \ldots \ldots \ldots \ldots \ldots \ldots \ldots . . .19$

15. Map showing wells in which water levels were measured at daily and irregular intervals, and absolute gravity monitoring sites.............................................................20

16. Map showing water-level contours for the period October-November $2006 \ldots \ldots \ldots \ldots \ldots \ldots \ldots \ldots . . .21$

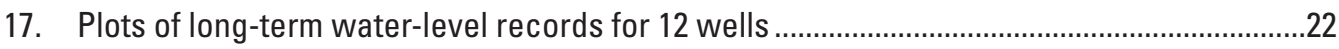


18. Plots of long-term water-level records in wells perforated in the coarse lower basin fill under confined or semiconfined conditions

19. Long-term water-level records in 10 wells near the San Pedro River, all measuring less than $60 \mathrm{~m}$ in depth, and perforated in the Holocene alluvium.

20. Plots of daily water levels in wells near the San Pedro River and streamflow at the gaging station San Pedro River near Tombstone, Arizona

21. Plots of daily water levels in wells near the San Pedro River and streamflow at the gaging stations San Pedro River near Tombstone, Arizona

22. Plots of daily water levels in wells near the San Pedro River and streamflow at the streamgaing stations San Pedro River near Benson, Arizona

23. Plots of cumulative aquifer storage change and rainfall in the Benson subarea for 2008 through 2010

24. Conceptual illustration of groundwater recharge and discharge in the middle San Pedro Watershed..

25. Plot showing decadal average annual groundwater recharge calculated from the distributed-parameter water balance model.

26. Plot showing decadal average annual recharge in the middle San Pedro Watershed calculated from the Southwest Alluvial Basins-Regional Aquifer System Analysis.......35

27. Plots of annual and seasonal streamflow seepage in the Benson and NarrowsRedington subareas of the middle San Pedro River Watershed, Arizona

28. Plot showing annual groundwater withdrawals for irrigation, municipal, self-supplied domestic, and industrial uses in the Benson subarea for 1936-2009.

29. Plot showing annual groundwater withdrawals for irrigation and self-supplied domestic uses in the Narrows-Redington subarea for 1936-2009.

30. Maps showing seasonal distribution of the groundwater component of evapotranspiration

31. Plot showing seasonal evapotranspiration (ET) and groundwater component of evapotranspiration in the Benson subarea for the years 2001-2009...

32. Plot showing seasonal evapotranspiration (ET) and groundwater component of evapotranspiration in the Narrows-Redington subarea for years 2001-2009.

33. Plot showing oxygen and hydrogen isotope composition in samples of precipitation in the middle San Pedro Watershed....

34. Plot showing $\delta^{18} 0$ compositions for precipitation relative to altitude of sample collection...51

35. Plots showing $\delta^{18} \mathrm{O}$ and $\delta^{2} \mathrm{H}$ values from surface-water samples plotted on the local meteoric water line.

36. Plots showing fluoride and sulfate in groundwater and surface water samples in the middle San Pedro Watershed.

37. Piper diagram showing relative ionic composition of surface water and groundwater in the middle San Pedro Watershed.

38. Plot showing $\delta^{18} \mathrm{O}$ and $\delta^{2} \mathrm{H}$ values from the San Pedro River collected in August 2008 .........53

39. Map showing locations of groundwater and surface water sampling sites ..........................54

40. Plot showing tritium values in groundwater samples from the middle San Pedro Watershed, plotted against $\delta^{18} 0$

41. Plot showing calcium and strontium ratios plotted against ${ }^{14} \mathrm{C}$ in groundwater samples from the middle San Pedro Watershed.

42. Plot showing sulfur isotope ratios $\left(\delta^{34} S\right)$ in groundwater and surface water.

43. Map of wells in the middle San Pedro Watershed

44. Box plots of fluoride concentration in groundwater for each aquifer type in the middle San Pedro Watershed. 


\section{Tables}

1. Streamflow-gaging stations on the San Pedro River in and near the middle San Pedro Watershed, Arizona.

2. Average annual streamflow and selected annual exceedance-level streamflows at gaging stations on the San Pedro River for specified periods of records...................10

3. Base flow discharge estimates at the Tombstone streamflow-gaging station ......................13

4. Predevelopment groundwater budgets for the Benson and Narrows-Redington subare

5. Distributed-parameter water-balance model calculated average annual runoff and recharge for 1940-2009 in the middle San Pedro Watershed and subareas.

6. Modified average annual natural recharge for the Benson subarea, NarrowsRedington subarea, and the Middle San Pedro Watershed for 1940-2009

7. Description of methods for estimating monthly seepage in reaches of the San Pedro River, middle San Pedro Watershed, Arizona.

8. Gains and losses in monthly measured streamflow between gaging stations

9. Average daily discharge and seepage values used to develop equation for estimating seepage between Tombstone and Benson

10. Regression equations for estimating monthly seepage along the San Pedro River...............40

11. Monthly changes in seepage along the San Pedro River between Charleston and Tombstone.

12. Average estimated annual rates of evapotranspiration and the groundwater component of evapotranspiration for 2001-2009 ...............................................................4

13. Groundwater budget for the Benson subarea for water years 2001-2009...........................49

14. Groundwater budget for the Narrows-Redington subarea for water years $2001-2009$.........50

15. Differences in physical and mineral characteristics and in constituent

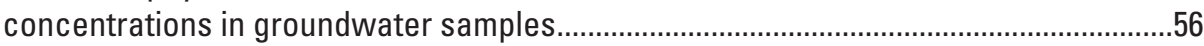

16. U.S. Environmental Protection Agency drinking-water-quality standards..............................57

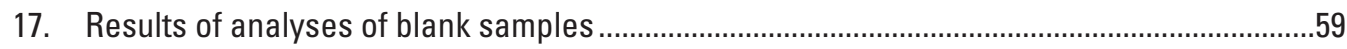

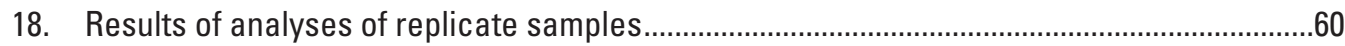

19. Differences in constituent concentrations between samples analyzed at the U.S. Geological Survey National Water Quality Laboratory and at the University of Arizona Department of Hydrology and Water Resources Laboratories.

A1. Water-quality data for precipitation, surface water, and groundwater in the middle San Pedro watershed collected from 2007 to February 2009.

A2. Water-quality data for groundwater in middle San Pedro Watershed collected in August and December 2009... 
This page left intentionally blank. 


\title{
Hydrology of the Middle San Pedro Watershed, Southeastern Arizona
}

\author{
By Jeffrey T. Cordova, Jesse E. Dickinson, Kimberly R. Beisner, Candice B. Hopkins, Jeffrey R. Kennedy, D.R.
} Pool, Edward P. Glenn, Pamela L. Nagler, and Blakemore E. Thomas

\section{Abstract}

In the middle San Pedro Watershed in southeastern Arizona, groundwater is the primary source of water supply for municipal, domestic, industrial, and agricultural use. The watershed comprises two smaller subareas, the Benson subarea and the Narrows-Redington subarea. Early 21 st century projections for heavy population growth in the watershed have not yet become a reality, but increased groundwater withdrawals could have undesired consequences - such as decreased base flow to the San Pedro River, and groundwaterlevel declines - that would lead to the need to deepen existing wells. This report describes the hydrology, hydrochemistry, water quality, and development of a groundwater budget for the middle San Pedro Watershed, focusing primarily on the elements of groundwater movement that could be most useful for the development of a groundwater model.

Precipitation data from Tombstone, Arizona, and base flow at the stream-gaging station on the San Pedro River at Charleston both show relatively dry periods during the 1960 s through the mid-1980s and in the mid-1990s to 2009, and wetter periods from the mid-1980s through the mid-1990s. Water levels in four out of five wells near the mountain fronts show cyclical patterns of recharge, with rates of recharge greatest in the early 1980s through the mid-1990s. Three wells near the San Pedro River recorded their lowest levels during the 1950s to the mid-1960s. The water-level record from one well, completed in the confined part of the coarse-grained lower basin fill, showed a decline of approximately 21 meters.

Annual flow of the San Pedro River, measured at the Charleston and Redington gages, has decreased since the 1940s. The median annual streamflow and base flow at the gaging station on the river near Tombstone has decreased by 50 percent between the periods 1968-1986 and 1997-2009. Estimates of streamflow infiltration along the San Pedro River during 1914-2009 have decreased 44 percent, with the largest decreases in the months June-October in the Benson subarea. In the Narrows-Redington subarea, streamflow infiltration has decreased about 65 percent during 1914-2009.

The average annual outflow $\left(27.6 \mathrm{hm}^{3} / y e a r\right.$ [cubic hectometers per year]) from the Benson subarea aquifer for water years 2001 through 2009 exceeded the inflows $\left(20.0 \mathrm{hm}^{3} / \mathrm{yr}\right)$ by $7.60 \mathrm{hm}^{3} / \mathrm{yr}$. In the Narrows-Redington subarea for the same period, the average annual outflow $\left(15.7 \mathrm{hm}^{3} / \mathrm{yr}\right)$ from the aquifer system exceeded the inflows $\left(13.8 \mathrm{hm}^{3} / \mathrm{yr}\right)$ by nearly $2 \mathrm{hm}^{3} / \mathrm{yr}$. The largest withdrawals of groundwater in both subareas are for irrigation; these withdrawals peaked in 1973 and have been steadily decreasing since then. Recharge from streamflow infiltration exceeded recharge from the mountain-front and from ephemeral channels in the Benson subarea. In the Narrows-Redington subarea, however, recharge from mountain-front and ephemeral channel recharge exceeded recharge from streamflow infiltration. Evapotranspiration by phreatophytes accounts for the largest outflow of groundwater for both subareas - 78 percent of the outflow in the NarrowsRedington subarea and 62 percent of the outflow in the Benson subarea.

Precipitation, surface-water, and groundwater chemistry and isotope data indicated the relative age and residence time of groundwater, the amount of interaction between geologic sources and groundwater, and how recharge elevation and season were related to the presence of modern water. The bedrock aquifer receives modern recharge $(<50$ years old $)$ that is a mix of both summer and winter precipitation; water in the fractured system has very little time to interact with the surrounding rock matrix. The unconfined basin-fill aquifer shows evidence of some modern recharge from multiple recharge seasons and altitudes; water has a long residence time with potential for increased water-rock interaction. The confined basin-fill aquifer does not receive a significant amount of modern recharge, and water has a long residence time with potential for increased water-rock interaction. The alluvial aquifer primarily receives modern recharge during the summer monsoon season by floodwater in the river.

\section{Acknowledgments}

The authors are grateful to Leslie Graser, Bill Remick, Tom Whitmer, Linda Stitzer, and John Fortune of the Arizona Department of Water Resources for their technical guidance throughout the study. The authors also wish to thank the many landowners in the San Pedro Basin that permitted land access and installation of hydrologic monitoring equipment. This study would lack much of the data essential to its success without their help and support. Mary McCool of the Community Watershed Alliance provided a forum for discussing technical aspects of the study. Apache Nitrogen Products 
shared data collected near St. David, Ariz. Barbara Clark and David Harris of The Nature Conservancy helped obtain land access for installation of monitoring equipment. Kathleen McHugh and Leo Leonhart of Hargis and Associates in Tucson, Ariz., provided well inventories and water levels for the St. David area. Mark McGowan, Daniel Weber, and Mark Cross of Errol L. Montgomery and Associates provided aquifer-test and geophysical data and helped to obtain land access. David Croft and Nathan Dieterich of the U.S. Bureau of Land Management helped collect water level data in the San Pedro Riparian National Conservation Area (SPRNCA). Christopher Eastoe and Jennifer McIntosh of the University of Arizona provided guidance in developing the geochemical model. Brandon Forbes and Jade Dickens of the U.S. Geological Survey assisted with the collection and compilation of water use data.

\section{Introduction}

Groundwater is the primary source of water for municipal, domestic, industrial, and agricultural use in the middle San Pedro Watershed (fig. 1), and demand for water resources in the watershed is projected to increase to meet the water needs of the growing population in the region (Barrios, 2005). To be effective and acceptable to all interested parties, planning and management of the groundwater supply needs to be guided by an objective and comprehensive scientific understanding of the groundwater system.

Benson, which had a population of 5,042 in 2009 (Arizona Department of Administration Office of Employment and Population Statistics, 2011), is the largest city in the middle San Pedro Watershed. The population of the area has grown moderately during the past 20 years (U.S. Census Bureau, 2006). In 2007, more than 20,000 housing units were planned for the Benson area, but because of the national economic recession, only 1,700 housing units were still planned for the area as of 2009 (Cochise College Center for Economic Research, 2007, 2009).

A wide range of interested parties is concerned about the future availability and sustainability of the water supply. Increased groundwater pumping could have several undesirable consequences, including loss of available groundwater storage, increased cost of pumping, the need to deepen existing wells and add new wells, impaired quality of drinking water, land subsidence, and damage to the riparian habitat of the San Pedro River. An improved understanding of the hydrologic system and of groundwater-surface-water interactions in the region will improve the capability of resource managers to optimally use this important resource and to minimize or mitigate the effects of development. This project is part of the Rural Watershed Initiative (RWI), a program established by the State of Arizona and managed by the Arizona Department of Water Resources (ADWR). In 2005, the U.S. Geological Survey (USGS) began this investigation of the hydrogeology of the middle San Pedro Watershed in cooperation with ADWR.

\section{Purpose and Scope}

This is the second of three planned USGS reports that describe the various aspects of the hydrology of the middle San Pedro Watershed. The first report described the hydrogeologic framework (Dickinson and others, 2010a). The purpose of the current report is to describe the occurrence and movement of surface water and groundwater, to analyze the hydrochemistry and water quality of surface water and groundwater, and to estimate a water budget for the subwatersheds and aquifer systems in the middle San Pedro Watershed.

This report includes the review of an extensive search of published and unpublished hydrologic information related to the middle San Pedro Watershed, including climate, streamflow, groundwater levels, and water-use data that were used to develop initial conceptual models and identify data needs. Climate records were analyzed to determine whether trends in precipitation correlate with trends in base flow and recharge. Streamflow records from several USGS gaging stations were analyzed to determine seasonal trends in streamflow. Water-level data from wells with more than 50 years of record were analyzed to provide information on the responses of the aquifer to changes in climate and groundwater withdrawals. Water-use data were compiled and analyzed to quantify groundwater withdrawals for domestic self-supply, and municipal, industrial, and irrigation uses. A distributedparameter, water-balance model was used to calculate available water for recharge. Remote-sensing data also were used to calculate groundwater outflow through evapotranspiration by riparian vegetation along the San Pedro River.

New groundwater-level data, particularly along the San Pedro River, were used to delineate groundwater flow patterns in shallow and deep aquifer units and to document the groundwater-level response to streamflow events in the San Pedro River. Additional water-level data from 325 wells were collected by the ADWR in 2006 to identify changes in the groundwater elevations. Groundwater and surface-water samples were collected and analyzed to describe the water quality in the basin and identify areas of groundwater recharge.

\section{Description of the Study Area}

The middle San Pedro Watershed (fig. 1) is within the Basin and Range Province (Fenneman, 1931) and lies in a north-trending structural trough that extends from south of the United States-Mexico border to several kilometers beyond the confluence of the Gila River. Although referred to herein as a watershed, the middle San Pedro Watershed does not technically conform to a watershed boundary and is more of a management area. The middle San Pedro Watershed comprises the northern portion of the Upper San Pedro Basin of Cochise County and the southern portion of the Lower San Pedro Basin of Cochise, Pima, and Graham Counties in southeastern Arizona. The Upper and Lower San Pedro Basins are groundwater management areas designated by the state of Arizona. 
The middle San Pedro Watershed covers an area of about $3,500 \mathrm{~km}^{2}$, is about $110 \mathrm{~km}$ from south to north, and 30 to $50 \mathrm{~km}$ wide. The western and eastern boundaries of the watershed coincide with the surface-water drainage of the San Pedro River. The Whetstone, Rincon, and Santa Catalina Mountains form the western boundary of the watershed. The eastern boundary is formed by the Dragoon, Little Dragoon, and Galiuro Mountains. The highest point in the watershed is 2,400 meters in the Rincon Mountains and the lowest point is 860 meters at the San Pedro River outflow at the Redington gaging station (hereafter "gaging station" or simply "station."
The San Pedro River flows from south to north and bisects the middle San Pedro Watershed. It begins near the USGS gaging station 09471550, San Pedro River near Tombstone (herein referred to as the Tombstone gaging station), and ends near the Redington Bridge, the location of USGS gaging station 094472050, San Pedro at Redington Bridge (herein referred to as the Redington Bridge gaging station). The southern boundary of the middle San Pedro Watershed coincides with the northern boundary of the Sierra Vista Subwatershed (fig. 1).The Upper and Lower San Pedro Basins are separated by a geologic constriction north
Figure 1. Map showing the middle San Pedro Watershed in southeastern Arizona. The boundary between the Benson and Narrows-Redington subareas, which passes through the Narrows, coincides with the boundary between the Upper and Lower San Pedro Basins.

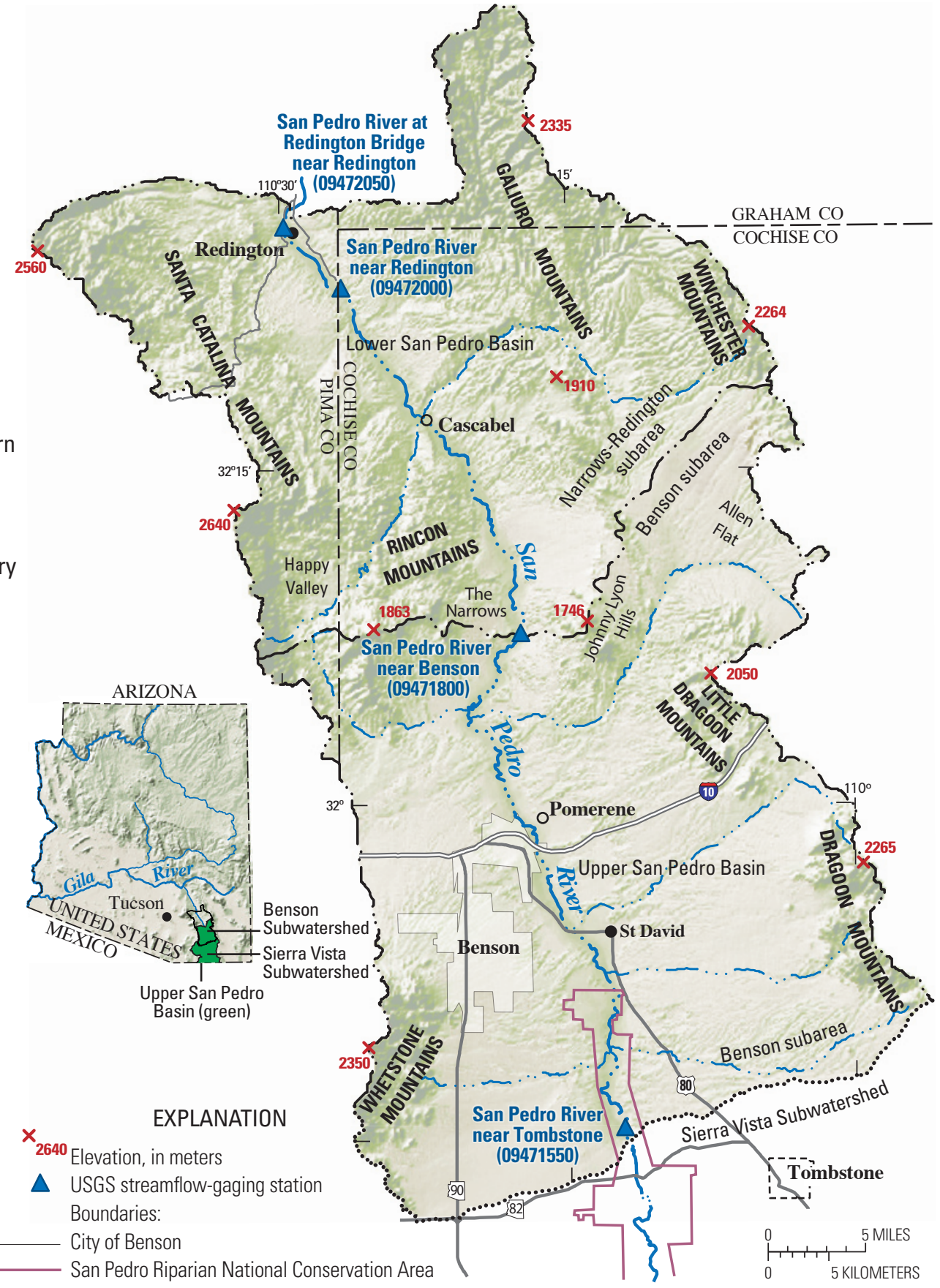

- - - - between the Benson and the Narrows-Redington subareas between the Benson subarea and the Sierra Vista Subwatershed
Base from U.S. Geological Survey digital data, 1:100,000, 1982 Universal Transverse Mercator projection, Zone 12 
of Benson, Arizona (fig. 1), near gaging station 09471800, San Pedro River near Benson (herein referred to as the Benson gaging station). This constriction is informally called the Narrows. Gaging station 09471000, San Pedro River at Charleston (herein referred to as the Charleston gaging station), is located about $14 \mathrm{~km}$ south of the southern boundary of the watershed.

The middle San Pedro Watershed is further divided into two smaller subareas. The part of the watershed within the Upper San Pedro Basin is referred to as the Benson subarea and the part within the Lower San Pedro Basin is referred to as the Narrows-Redington subarea (fig.1). The Upper and Lower San Pedro Basins combined have been referred to as the San Pedro River Valley (Roeske and Werrell, 1973).

The San Pedro River flows from its origins in Mexico north to the Gila River north of the middle San Pedro Watershed. The river is intermittent from the southern boundary of the middle San Pedro Watershed to St. David $(21 \mathrm{~km})$ and is mostly ephemeral from St. David to the northern boundary at Redington $(84 \mathrm{~km}$ ) (Dickinson and others, 2010a). All the tributaries to the river are ephemeral, incised less than $10 \mathrm{~m}$, and generally flow at right angles to the river. The Arizona-Idaho Conservation Act of 1988 designated $60 \mathrm{~km}$ of the San Pedro River from the international boundary north to near St. David as the San Pedro Riparian National Conservation Area (SPRNCA). The purpose of the designation is to protect and enhance this desert riparian ecosystem. The northernmost $14 \mathrm{~km}$ of the SPRNCA are within the Benson subarea of the middle San Pedro Watershed.

In 2009, the population in the Benson Census County Division (CCD) was 12,449 (Arizona Department of Commerce, 2010). The Benson CCD is a subdivision of a county designated by the U.S. Census Bureau and coincides with portions of the middle San Pedro Watershed in Cochise County. The Benson CCD includes the City of Benson (population 5,042 in 2009), the unincorporated area of St. David, and surrounding unincorporated areas.

\section{Previous Investigations}

The geology and hydrology of the San Pedro River Valley have been studied since the early 20th century. The hydrology of the valley has been investigated mainly to locate and quantify water resources, to describe the quality of water available for human use, and to improve understanding of how the hydrologic system responds to climatic and anthropogenic stresses. The geology has been investigated to improve the understanding of the geologic history and geologic structure as well as for mineral exploration. In the 1990s and 2000s, comprehensive studies by the USGS, in cooperation with ADWR, the Upper San Pedro Partnership, and university researchers, led to much of the current understanding of the hydrogeology of the Upper San Pedro Basin, including groundwater-surface-water connections and of the health of the riparian areas in the SPRNCA.
Geologic investigations generally mapped and described the geologic structure of the San Pedro River Valley and proposed a geologic history for some of the major features. The scales of previous geologic investigations range from small, individual basin studies to regional studies across the state of Arizona (Shafiqullah and others, 1980; Scarborough and Peirce, 1978; Drewes, 1981; Dickinson, 1991). The entrenchment and widening of the San Pedro River as well as the extent of the Holocene channel and floodplain alluvium have been investigated by Hereford (1993), who described the preentrenchment evolution of the San Pedro River channel from the international boundary to near St. David. Cook and others (2009) mapped the Holocene River Alluvium along the San Pedro River.

The earliest hydrologic investigations in the San Pedro Valley were conducted by Lee (1905) and by Bryan and others (1934). Lee (1905) described the early groundwater development near the Benson area. Bryan and others (1934) focused on describing hydrologic conditions for the purpose of obtaining water for irrigation along the San Pedro River near St. David and Pomerene. They identified confined groundwater conditions and artesian wells in areas near those communities. The hydrologic conditions of the San Pedro Valley were also summarized by Roeske and Werrell (1973), who from 1966 to 1968 inventoried wells, measured water levels, and mapped irrigated fields in 1966. They also collected samples of groundwater for analysis of water quality in the San Pedro Valley.

Descriptions of hydrogeologic units have focused primarily on the Sierra Vista Subwatershed and are provided by Brown and others (1966), Freethey (1982), Jahnke (1994), Corell and others (1996), Maddock III and Vionnet (1998), Pool and Coes (1999), Goode and Maddock (2000), Leenhouts and others (2006), and Coes and Pool (2007). The hydrogeologic units discussed by these authors also extend into or are similar to the units within the middle San Pedro Watershed (Dickinson and others, 2010a). Interpretations of the hydrogeologic framework of the previous studies were mainly based on data from geologic maps, descriptions of the aquifer lithology from driller's logs, and rarely, aquifer tests.

The collection of geophysical data in the San Pedro River Valley has led to improvements and refinements to the hydrogeologic framework. Results of detailed airborne geophysical surveys of the Sierra Vista Subwatershed in the late 1990s (Wynn, 2006) and application of the geophysical survey to improve a groundwater flow model (Pool and Dickinson, 2007) convinced ADWR to further utilize airborne electromagnetic methods to explore the aquifer system in the middle San Pedro Watershed as well as in a number of other basins across Arizona. The results of the airborne electromagnetic surveys were used to further refine the hydrogeologic framework of the middle San Pedro Watershed (Dickinson and others, 2010a; 2010b).

Investigations have been performed to improve the understanding of the groundwater flow system in the Upper San Pedro Basin. Pool and Coes (1999) analyzed precipitation, streamflow, geophysical, hydrochemical, and water-level data to refine the hydrogeologic framework and increase 
understanding of stream-aquifer interactions and rates and locations of base flow depletion owing to groundwater withdrawals. Coes and Pool (2007) collected and analyzed water chemistry data and geophysical profiles from bore holes in ephemeral stream channels and on the basin floor to estimate infiltration and recharge in the Sierra Vista Subwatershed.

Most groundwater modeling efforts in the San Pedro Valley have been focused on the Sierra Vista Subwatershed in the Upper San Pedro Basin (Freethey, 1982; Anderson and others, 1992; Putman and others, 1988; Vionett and Maddock, 1992; Corell and others, 1996; Pool and Dickinson, 2007). Models were developed to simulate groundwater conditions for the entire San Pedro River Valley as well as for various subareas outside of the Sierra Vista Subwatershed. Anderson and Freethey (1995) modeled the groundwater conditions around the Benson subarea and the area from the Narrows to the confluence of the San Pedro River and the Gila River. Rovey (1989) modeled groundwater conditions of the entire San Pedro River Valley from the international boundary to Winkleman, Arizona. Rovey (1989) used seepage rates along the San Pedro River to estimate the impact of groundwater on surface flows. Jahnke (1994) simulated the groundwater conditions from Fairbank to Redington. Goode and Maddock (2000) simulated the groundwater conditions of the entire San Pedro River Valley, including the portion in Mexico for the time period 1940-1997. Whittier and Maddock (2004) simulated groundwater conditions from the Narrows to the confluence of the San Pedro and Gila Rivers for the period 1940-2000.

Trends in annual streamflow in the San Pedro River have been investigated to improve water budget estimates in the Upper San Pedro Basin. The streamflow record from the Charleston gage has been used in numerous investigations to infer hydrologic change in the Upper San Pedro Basin (Freethey, 1982; Putman and others, 1988; Vionnet and Maddock, 1992; Hereford, 1993; Corell and others, 1996; Sharma and others, 1997; Rojo and others, 1999; Pool and Coes, 1999; Thomas and Pool, 2006). The streamflow record at the Tombstone gage has been analyzed to determine the base flow component of the groundwater budget in the Upper San Pedro Basin (U.S. Department of the Interior, 2011). Kennedy and Gungle (2010) conducted a detailed analysis of base flow at the Tombstone gage in which they analyzed precipitation records, isotope samples, groundwater levels, vertical gradients, and the streamflow record to estimate the volumes and sources of annual base flow at the Tombstone gage. Kennedy and Gungle (2010) also discussed the decreasing trend in base flow at the Tombstone gage.

Prior to 2000, most estimates of the groundwater withdrawals from riparian evapotranspiration (ET) were estimated using groundwater-flow models. The first detailed estimates of ET by riparian vegetation in the Upper San Pedro Basin were made using remote sensing data and field measurements (Goodrich and others, 2000). Those estimates of riparian groundwater withdrawals were later updated by Scott and others (2006) using eddy-covariance techniques for various riparian vegetation types. Nagler and others (2005a) combined in-place measurements with remote sensing to estimate riparian ET in the Upper San Pedro Basin for years 2000-2004. Scott and others (2008) used ET rates from eddy covariance methods to develop an empirical relation between ET and remote sensing data and land surface temperature to scale up ET rates in the Upper San Pedro Basin.

The results of studies of water quality in the middle San Pedro Watershed have been included in sections of other reports, but have not been as prominent as the findings of studies of quantitative aspects of water resources. Water-quality studies have attempted to determine groundwater quality as a function of well location in the basin, well depth, aquifer type, geology, and land use. Roeske and Werrell (1973) found the chemical quality of the groundwater in the San Pedro River Valley to be suitable for most uses but described high levels of fluoride in the St. David-Benson and Mammoth areas. Coes and others (1999) collected water samples from wells between the international boundary with Mexico and the Benson Narrows and analyzed the samples for general mineral, nutrient, and trace constituents. Towne (2002) sampled groundwater at 63 sites in the Lower San Pedro Basin for analyses of inorganic constituents and volatile organic compounds and radiochemistry. Samples were collected from selected wells for analysis of radon and pesticides.

Results of analyses of groundwater samples from the San Pedro River Valley have been used to infer the movement and ages of groundwater. Coes and Pool (2007) collected and analyzed water chemistry data and geophysical profiles from bore holes in ephemeral-stream channels and the basin floor to estimate infiltration and recharge rates in the Sierra Vista Subwatershed. They found that as much as 19 percent of basin recharge occurs in washes where infiltration rates were about two orders of magnitude greater than those on the basin floor. Hopkins (2014, see also Adkins, 2009) collected water solute and isotope geochemistry samples from wells, the San Pedro River, and precipitation in the middle San Pedro Watershed to describe movement of groundwater and residence times. Hopkins (2014) found evidence for focused recharge in fracture systems along the mountain blocks flanking the basin and that winter precipitation contributes to recharge in the fracture system and the unconfined aquifer whereas summer precipitation recharges the alluvial aquifer.

All of the previously mentioned investigations have greatly improved the understanding of the geology and hydrology of the San Pedro River Valley and have led to the development of a groundwater budget for the Sierra Vista Subwatershed. Although similarities can be drawn between the conditions in the Sierra Vista Subwatershed and the middle San Pedro Watershed, significant differences might exist between the two areas. The presence of a confining unit in the St. David area may limit groundwater flow through the middle San Pedro Watershed and affect groundwater quality. Riparian groundwater use has not been quantified in the middle San Pedro Watershed. Seasonal rates of available water for mountain front and mountain block recharge in the middle San Pedro Watershed have not been determined. This study aims to fill these knowledge gaps and develop a water budget for the middle San Pedro Watershed. 


\section{Climate}

The climate in the middle San Pedro Watershed is arid or semiarid, and precipitation falls mainly during winter and summer months (fig. 2; Pool and Coes, 1999; Pool, 2005; Thomas and Pool, 2006). Temperature and precipitation generally vary with altitude, although some variations are attributed to local rain-shadow effects. Mean annual precipitation along the basin floor at Tombstone from 1913 to 2009 is $351 \mathrm{~mm}$ (National Weather Service Cooperative Network, http://www.nws.noaa.gov/om/coop/, accessed January 21, 2010; Agricultural Research Service Southwest Watershed Research Center, http://www.tucson.ars.ag.gov/dap/, accessed January 22, 2010). The mean annual precipitation in the Rincon and Catalina Mountains is greater than $750 \mathrm{~mm}$ [based on PRISM (Parameter-elevation Regressions on Independent Slopes Models) data sets (PRISM, 2010)]. Mean monthly maximum temperatures in June and July on the basin floor are about $34^{\circ} \mathrm{C}$ at Tombstone, $37^{\circ} \mathrm{C}$ at Cascabel, and $25^{\circ} \mathrm{C}$ at Mount Lemmon in the Santa Catalina Mountains, which is west of the study area but has a climate similar to that in the Rincon Mountains. Mean monthly minimum temperatures during December and January are about $2{ }^{\circ} \mathrm{C}$ at Tombstone, $-1{ }^{\circ} \mathrm{C}$ at Cascabel, and -4 to $-5{ }^{\circ} \mathrm{C}$ at Mount Lemmon (Western Region Climate Center, http://www.wrcc. dri.edu/summary/Climsmaz.html, accessed August 16, 2010).

Seasonal differences in precipitation (fig. 2) result from several sources of moisture and different types of storms that transport moisture and deliver the precipitation. Winter season (November to February) cumulative precipitation (average of $79 \mathrm{~mm}$ at Tombstone) is delivered by mid-latitude low pressure systems from the Pacific Ocean. Individual precipitation events are generally widespread, long in duration, and of low intensity. Dry season (March to May) cumulative precipitation averages $26 \mathrm{~mm}$ at Tombstone, and is less common because frontal systems remain to the north of the study area. Wet season (June to October) cumulative precipitation (average of $246 \mathrm{~mm}$ at

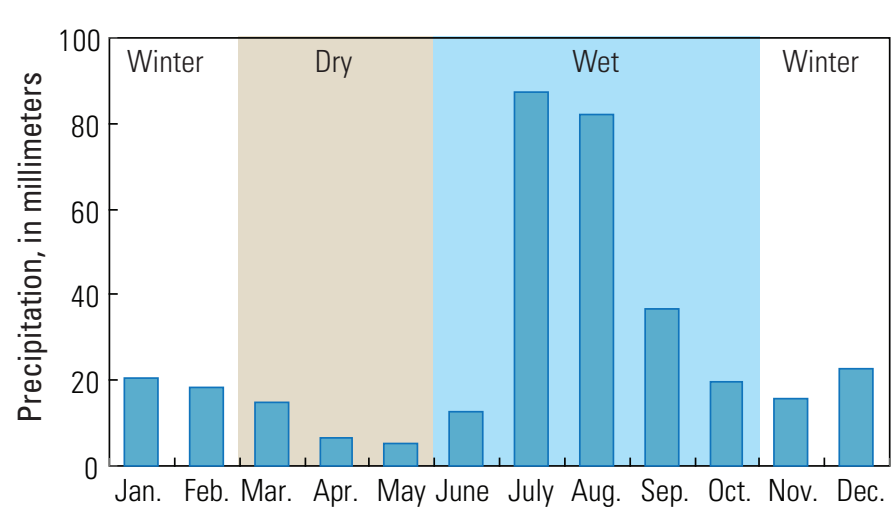

Figure 2. Bar graph showing average monthly precipitation at Tombstone, Arizona, 1913-2009.
Tombstone) is delivered by local convective thunderstorms of short duration and high intensity, which are fed by moisture from the Gulf of Mexico, Gulf of California, and Pacific Ocean. Precipitation during the latter part of the wet season can originate from convective thunderstorms, frontal systems, and dissipating tropical cyclones. Most precipitation occurs during the summer months (fig. 3). Residual moisture from tropical cyclones, in combination with monsoonal flow or with cutoff low-pressure systems from the Pacific Ocean, has contributed to the largest and most widespread floods in Arizona (Webb and others, 2004).

Long-term variations in climate in the southwestern United States (Cayan and Webb, 1992; Webb and Betancourt, 1992; McCabe and Dettinger, 1999; Dettinger, 2005; Pool, 2005; Hidalgo and others, 2009) can have immediate or long-term effects on water resources, including rates of groundwater recharge, streamflow, runoff in ephemeral channels, water use by plants in riparian areas, and human water use. Climate variability in southeastern Arizona and the frequency and magnitude of runoff-producing precipitation has been attributed to large-scale atmospheric patterns. The cumulative departure of precipitation from long-term averages, which represents periods of successive years of either greater or lower-than-average precipitation, is used to separate interannual and interdecadal variations into wet and dry climatic periods (fig. 4). Wet climatic periods are indicated by the rising limb and dry climatic periods by the falling limb of the cumulative departure curve. Some of the largest floods in Arizona occurred during wet periods in the beginning (1905 and 1916) and end of the 20th century (1983 and 1993). A multidecadal drought occurred in the middle of the 20th century, and another appears to be ongoing in the early 21 st century. The wet and dry periods also correspond well to the cumulative departure from the long term average of base flow in the San Pedro River at the Charleston gaging station (09471000), suggesting that variations in groundwater discharge as base flow in the San Pedro River also occurs at interannual and interdecadal time scales.

\section{Surface Water}

Surface-water features in the middle San Pedro Watershed include the San Pedro River and ephemeral channels that originate in the surrounding mountains and drain into the San Pedro River. The length of the San Pedro River within the study area is about $105 \mathrm{~km}$ from the southern to northern boundary. The elevation of the river along that length drops from $1,150 \mathrm{~m}$ to $860 \mathrm{~m}$ and has an average gradient of $2.8 \mathrm{~m} / \mathrm{km}$. In the Benson subarea, the river is $58 \mathrm{~km}$ long and has an average gradient of $2.5 \mathrm{~m} / \mathrm{km}$. In the NarrowsRedington subarea, the river is slightly steeper with a length of $47 \mathrm{~km}$ and an average gradient of $3.2 \mathrm{~m} / \mathrm{km}$. The active channel of the river varies in width from several meters to tens of meters, and the channel is incised into the floodplain 


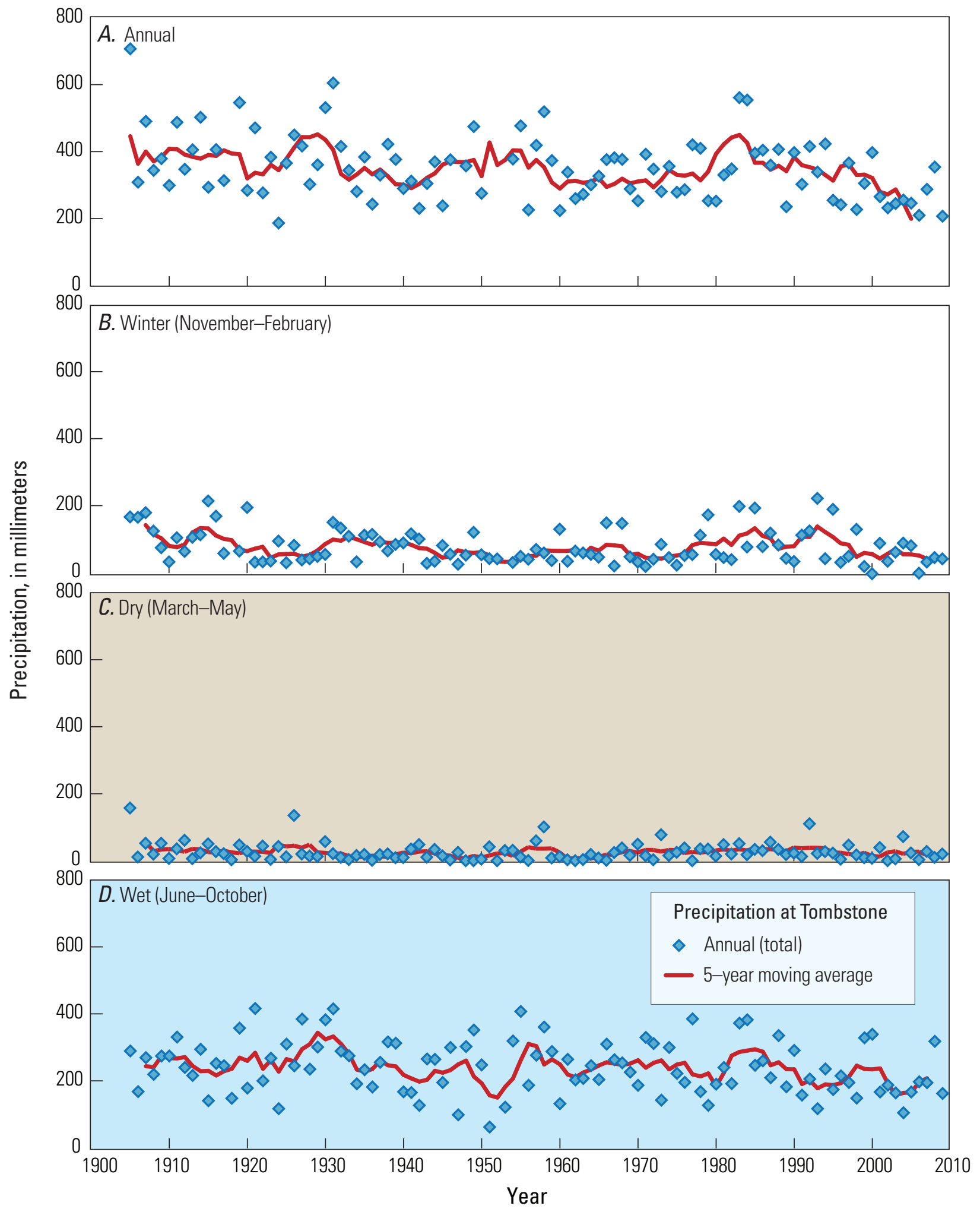

Figure 3. Scatter plots showing annual and seasonal precipitation at Tombstone, Arizona, 1905-2009. A, Annual. B, Winter (November-February). C, Dry season (March-May). D, Wet season (June-October). The solid line is the 5 -year moving average of the annual values. 
from 1 to $10 \mathrm{~m}$. In the Benson subarea, the river valley is about $40-50 \mathrm{~km}$ wide, the basin slopes moderately upward to mountain elevations of about $2,000 \mathrm{~m}$ on the west and 2,100 $\mathrm{m}$ on the east, and tributaries are incised. In the NarrowsRedington subarea, the river valley is about $30-40 \mathrm{~km}$ wide, the basin slopes steeply upward to mountain elevations of about 2,600 $\mathrm{m}$ on the west and 2,300 $\mathrm{m}$ on the east, and tributaries are steep and deeply incised. All tributaries to the river are ephemeral and ungaged and generally flow at right angles to the main channel of the San Pedro River.

Flow in the San Pedro River is intermittent for approximately $21 \mathrm{~km}$ from the southern boundary near Tombstone to St. David. The San Pedro River is ephemeral between St. David and the Narrows, as well as between the Narrows and the northern boundary of the study area at Redington, except for intermittent, perennial reaches approximately $3.5 \mathrm{~km}$ north of the Narrows.

\section{Streamflow Data}

The Charleston gaging station, approximately $18 \mathrm{~km}$ upstream (south) of the southern boundary of the middle San Pedro Watershed (fig. 1), has the longest streamflow record in the Upper San Pedro Basin (table 1). The Charleston gaging station was established in 1904 but was moved several times prior to 1936. For this study, the streamflow record at the gaging station is analyzed over water years 1936-2009.

The Tombstone gaging station is just north of the southern boundary of the watershed and measures the surface water entering the watershed. The streamflow records for water years 1968-1986 and 1997-2009 were analyzed separately, as the station was discontinued from 1987-1996. Accordingly, separate flow statistics are presented for the two periods during which the station was operational (table 1). The Benson gaging station near the Narrows records flow in the San Pedro

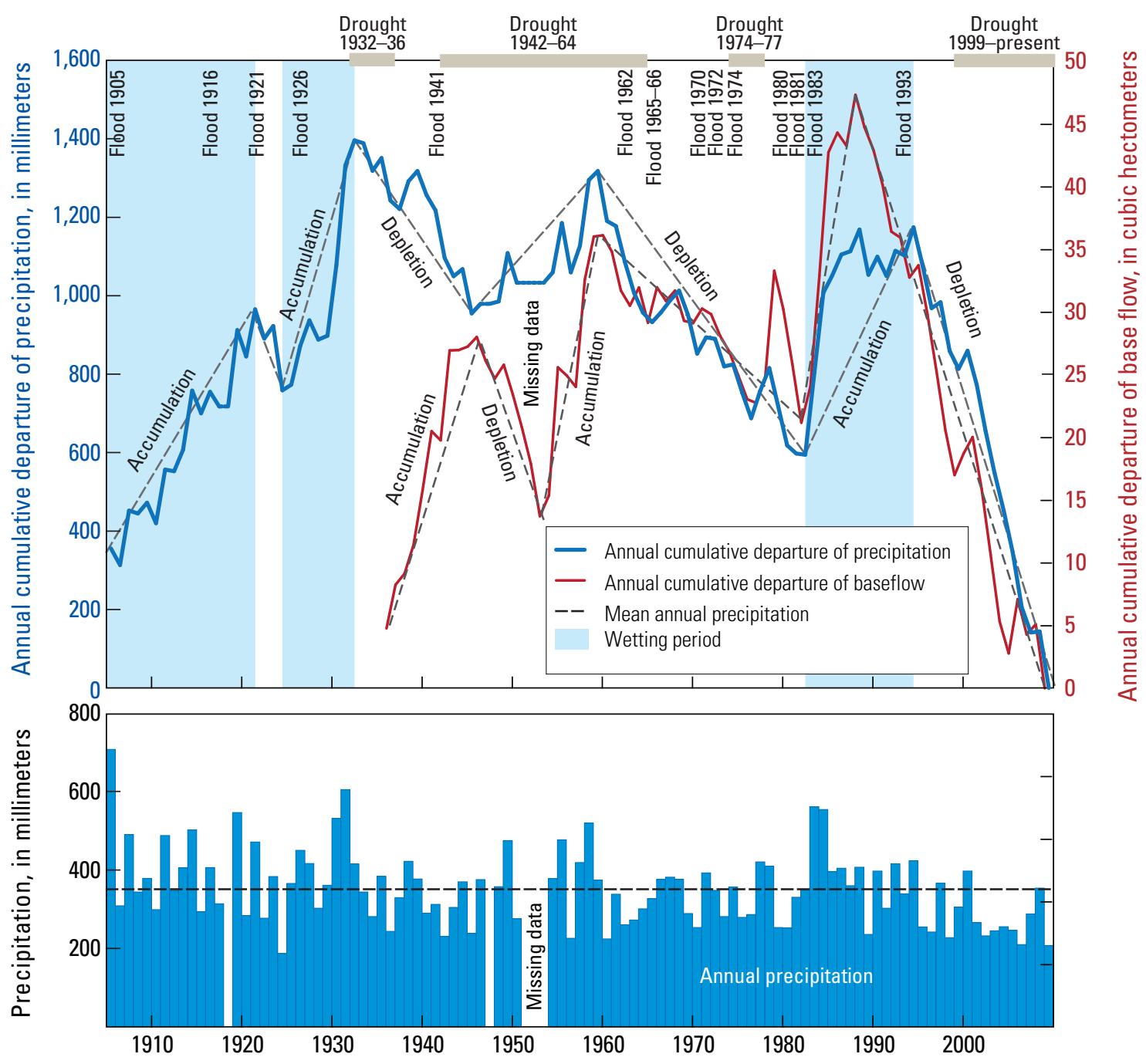

Figure 4. Bar graph of annual precipitation at Tombstone, Arizona (bottom), and plots of annual cumulative departures from the long-term average for precipitation (blue line) and base flow (red line) in the San Pedro River (top). The jagged dashed gray lines are schematic, illustrating inferred periods of aquifer accumulation and depletion, based upon the trends in the departure curves. The black dashed line is the mean annual precipitation. 
Table 1. Streamflow-gaging stations on the San Pedro River in and near the middle San Pedro Watershed, Arizona.

\begin{tabular}{cllccc}
\hline $\begin{array}{l}\text { U.S. Geological Survey } \\
\text { gaging-station number }\end{array}$ & \multicolumn{1}{c}{ Location } & Period of record & $\begin{array}{c}\text { Drainage } \\
\text { area (square } \\
\text { kilometers) }\end{array}$ & $\begin{array}{c}\text { Gage datum } \\
\text { (meters above } \\
\text { sea level) }\end{array}$ \\
\hline 09471000 & at Charleston & $1913-2009$ & 3,196 & 1,205 \\
09471550 & near Tombstone & $1968-1986 ; 1997-2009$ & 4,507 & 1,152 \\
09471800 & near Benson & $1967-1976 ; 2006-2009$ & 6,449 & 1,009 \\
09472000 & near Redington & $1944-1997$ & 7,581 & 896 \\
09472050 & at Redington Bridge near Redington & $1998-2009$ & 8,019 & 860 \\
\hline
\end{tabular}

River out of the Benson subarea into the Narrows-Redington subarea. The streamflow record at the Benson gage started in March 1966 and ended in March 1976 and starts again in October 2005 and ends in 2009.

The San Pedro River near Redington (09472000) gaging station (herein referred to as the Redington gage and distinct from the currently operating Redington Bridge gage, $6 \mathrm{~km}$ to the north) measured streamflow about $8 \mathrm{~km}$ upstream of the northern boundary of the watershed from 1944 to 1997 but is missing data for the years 1948 and 1949. The streamflow measurements at the gage were affected by an upstream diversion for irrigation and to fill a stock pond. The first mention of upstream diversions is in January of 1972. Field notes from the Redington gage between 1972 and 1998 were used to identify months when water was being diverted out of the San Pedro River. The notes describe water in the San Pedro River being diverted by a "sand berm." The diversions occurred year round but were most frequent during the months of April and May. When water was diverted, usually the entire flow was diverted out of the San Pedro River and the Redington gage would record zero discharge. The streamflow during the monsoon season was probably not affected by the streamflow diversions because the flow would likely wash away the sand barrier in the stream channel that was used to divert the flow.

In July 1998, the Redington gaging station was deactivated, and a new station was constructed at the Redington Bridge, approximately $6 \mathrm{~km}$ downstream from the original station. The drainage area to the new station is six percent greater than that for the original station. The flow data from both gages are assumed to have similar characteristics and trends, and were combined into a single record for the period 1944-2009 for this study and report. The combined records of the Redington and Redington Bridge gages are referred to as the combined Redington gage record. The record at the new location is still affected by the upstream diversion.

\section{Streamflow Characteristics and Trends}

Streamflow characteristics for the San Pedro River were calculated through analysis of data from five streamflow-gaging stations (table 2). The active stations from south to north are those at Charleston, near Tombstone, near Benson, and at Redington Bridge (fig. 1). The record for the discontinued station near Redington was also analyzed for this study.

Annual streamflow statistics - average annual flow values, and the 10-, 50-, and 90-percent exceedance values - presented in this report are calculated from the period of record ending on September 30, 2009. The term "exceedance" refers to the streamflow value that is met or exceeded for a given percentage of the specified period of record. For example, the 50 percent exceedance probability (also called the median), is one of the most commonly used or cited percentiles; it represents the streamflow that is equaled or exceeded 50 percent of the time. The 10-percent exceedance probability characterizes streamflow that is equaled or exceeded 10-percent of the specified time period. Streamflow volumes for Tombstone were described for wet, dry, and winter periods. Long-term annual trends were determined from the Charleston and Redington streamflow gages. The record from the Charleston gage, which is just outside (south of) the middle San Pedro Watershed, was used for the analysis because of its long record, starting in 1936. Base flow to the San Pedro River was estimated on the basis of the monthly 3-day minimum flows during the winter at the Charleston and Tombstone gages; this method was also used by Thomas and Pool (2006).

Long-term streamflow records from the Charleston and combined Redington gages show a decreasing trend in average annual streamflow (fig. 5). Average annual flow at the Charleston gage was about $60 \mathrm{hm}^{3} / \mathrm{yr}$ for the period 1936-1940, and $32 \mathrm{hm}^{3} / \mathrm{yr}$ for the period 2000-2009.

Average annual streamflow at the combined Redington gage was $46 \mathrm{hm}^{3} / \mathrm{yr}$ for the period 1944-1957 and $25 \mathrm{hm}^{3} / \mathrm{yr}$ for the periods 2000-2009. The record at the Tombstone gage also shows a decrease in the average annual streamflow (fig. 6). The median values have decreased by 50 percent, from $0.34 \mathrm{~m}^{3} / \mathrm{s}$ to $0.17 \mathrm{~m}^{3} / \mathrm{s}$, for the periods $1968-1986$ and 1997-2009, respectively (table 2).

For the period of record 1936-2009, the average annual streamflow at the Charleston gage was $1.29 \mathrm{~m}^{3} / \mathrm{s}$ $\left(40.54 \mathrm{hm}^{3} / \mathrm{yr}\right.$; table 2$)$. The average annual streamflow at the Tombstone gage was $1.57 \mathrm{~m}^{3} / \mathrm{s}\left(84.17 \mathrm{hm}^{3} / \mathrm{yr}\right)$ for the early period of record, 1968-1986, and the average annual streamflow for the later period of record, 1997-2009, was $0.99 \mathrm{~m}^{3} / \mathrm{s}\left(57.52 \mathrm{hm}^{3} / \mathrm{yr}\right.$; table 2$)$. The average annual 
Table. 2 Average annual streamflow and selected annual exceedance-level streamflows at gaging stations on the San Pedro River for specified periods of records.

[Abbreviations: $\mathrm{m}^{3} / \mathrm{s}$, cubic meters per second; $\mathrm{hm}^{3} / \mathrm{yr}$, cubic hectometers per year]

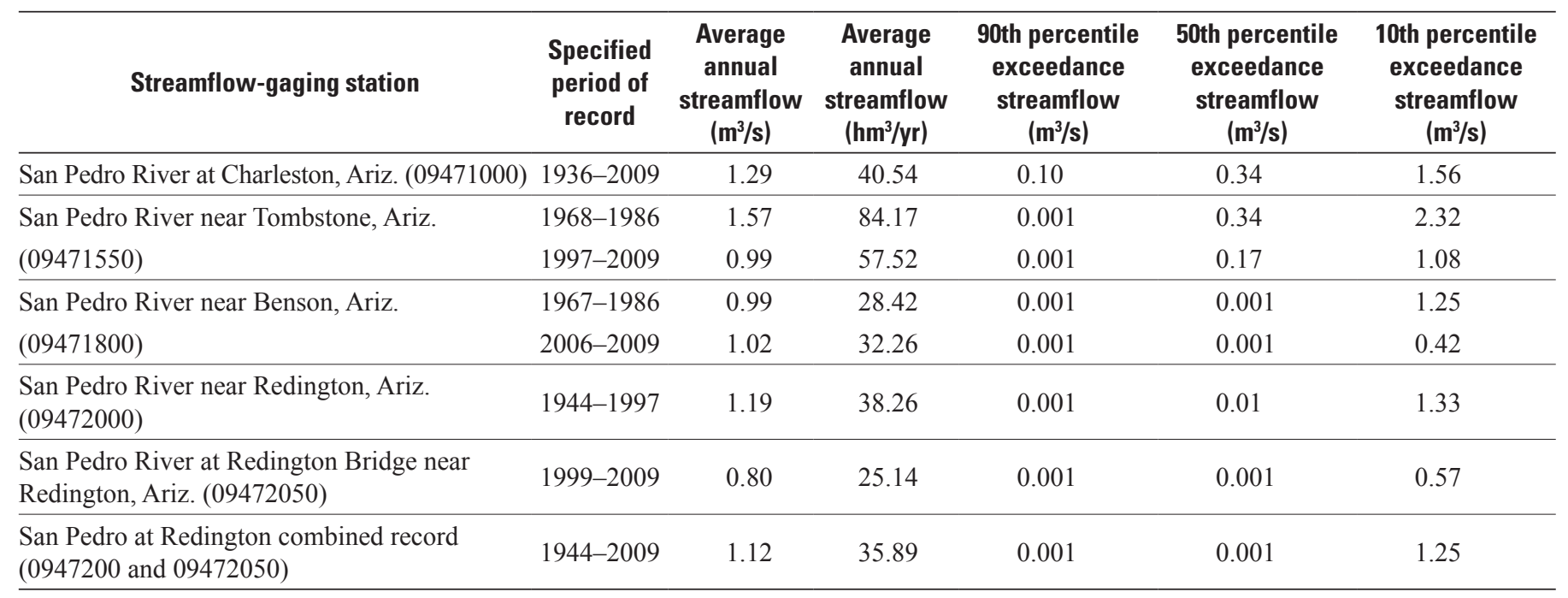

${ }^{1}$ Ephemeral streamflow; streamflow is present at least 90 percent of the specified time period

${ }^{2}$ Ephemeral streamflow; streamflow is present at least 50 percent of the specified time period

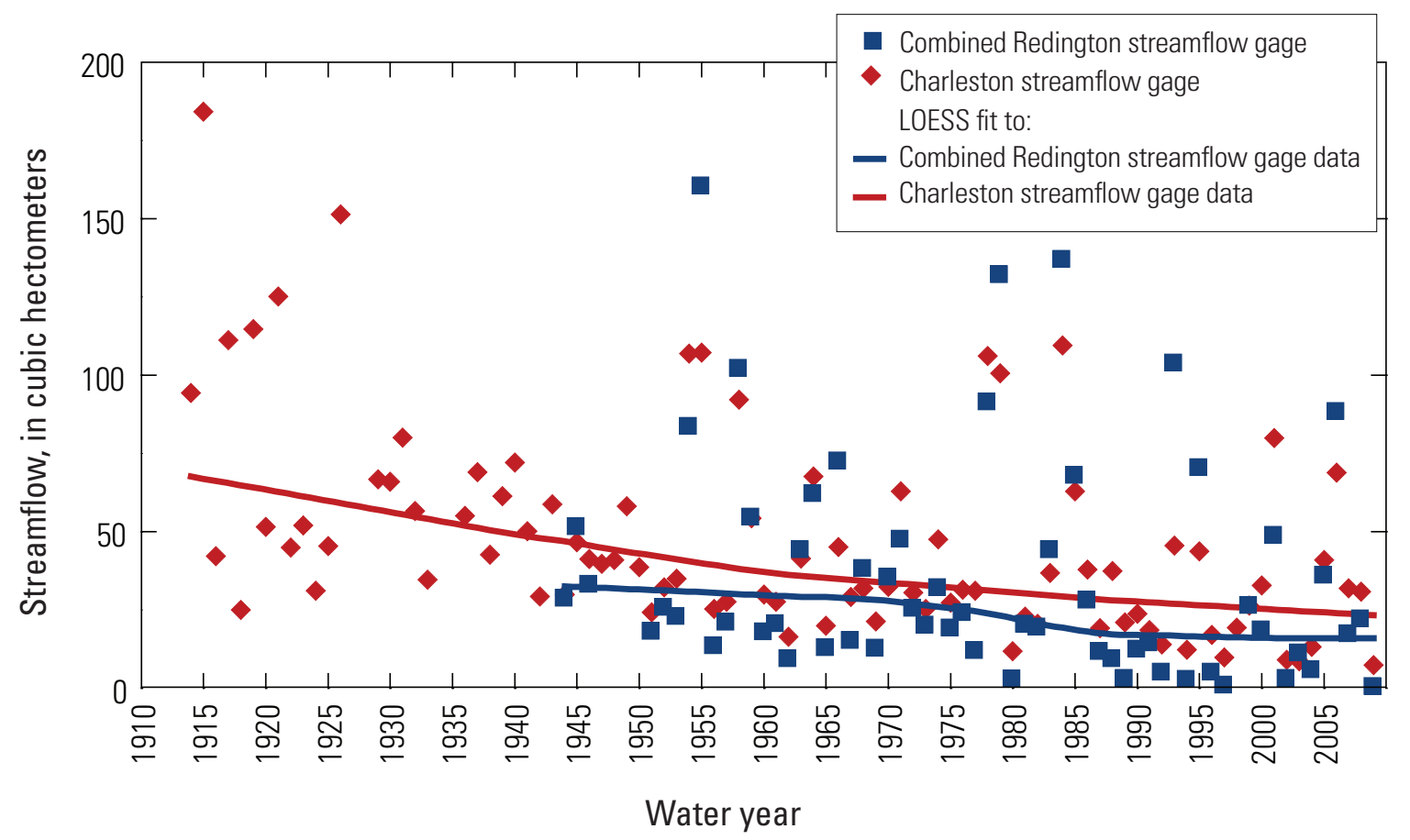

Figure 5. Scatter plot of annual streamflow of the San Pedro River at Charleston, Arizona (09471000) and combined record from the gaging stations San Pedro River near Redington, Arizona (09472000) and San Pedro River at Redington Bridge near Redington, Arizona (09472050). The solid red and blue lines are LOWESS fit to the respective streamflow record (locally weighted scatterplot smoothing [Cleveland, 1979]). 
streamflow at the Benson gage was $0.99 \mathrm{~m}^{3} / \mathrm{s}\left(28.42 \mathrm{hm}^{3} / \mathrm{yr}\right)$ for the 1967-1976 period and the average annual streamflow for the time period $2006-2009$ was $1.02 \mathrm{~m}^{3} / \mathrm{s}\left(32.26 \mathrm{hm}^{3} / \mathrm{yr}\right.$; table 2). For the combined period of records from 1944-2009 the average annual streamflow of the combined Redington gage was $1.12 \mathrm{~m}^{3} / \mathrm{s}\left(35.89 \mathrm{hm}^{3} / \mathrm{yr}\right.$; table 2$)$.

The 90-percent, 50-percent, and 10-percent streamflow exceedance values were calculated for the five gages for their periods of record (table 2). At the Charleston gage, all of the exceedance percentiles were greater than zero, which is indicative of perennial streamflow. Ten- and 50-percent exceedance values equal to $0 \mathrm{~m}^{3} / \mathrm{s}$ are indicative of ephemeral channels. The 10-percent exceedance values for all gages were all greater than zero. In general, the exceedance streamflow values show that streamflow is nearly always present at the Charleston gage and decreases downstream as the water is lost to infiltration and evapotranspiration (ET) by phreatophytes. Streamflow also is lost to evaporation, and, at times, diversions.

The average daily discharge values show the variability in streamflow at the Tombstone, Benson, and Redington Bridge gages for their periods of record (fig. 7). All three gages show streamflow beginning to increase in July and peaking in early August, then decreasing to zero discharge in October. At the Benson station, there is virtually no flow from October through July. The Tombstone and Redington Bridge gages show flashy streamflow events in October and November but these flows are smaller and of shorter duration than summer streamflow events. The Redington Bridge gage shows streamflow events occurring during mid-January through March.

Peak discharges on the San Pedro River occur most often in the wet months as a result of monsoon storms. The peaks of record at the Charleston and combined Redington gages-2,775 $\mathrm{m}^{3} / \mathrm{s}$ and $2,549 \mathrm{~m}^{3} / \mathrm{s}$, respectively-occurred on Sept. 28, 1926 (fig. 8). The annual peaks at the Tombstone and Benson gages all occurred in the wet months. The peak discharge has occurred during the winter months at the combined Redington gages for water years 1968, 1979, $1985,1993,1995$, and 2008. In 1995, peak discharge at the Charleston gage occurred during the winter months. The peak discharge has only once occurred during the dry months, in 1991, at both the Redington and Charleston streamflow gages.

\section{Base Flow}

The flow of the San Pedro River at the Tombstone gaging station includes both runoff and base flow. Runoff originates from precipitation in the surrounding mountains and basin and reaches the San Pedro River by overland flow and in tributaries. Base flow is the discharge of groundwater from the regional aquifer and from the shallow stream alluvium. The definition of base flow differs depending on the author and focus of the study. In this study, base flow at Tombstone

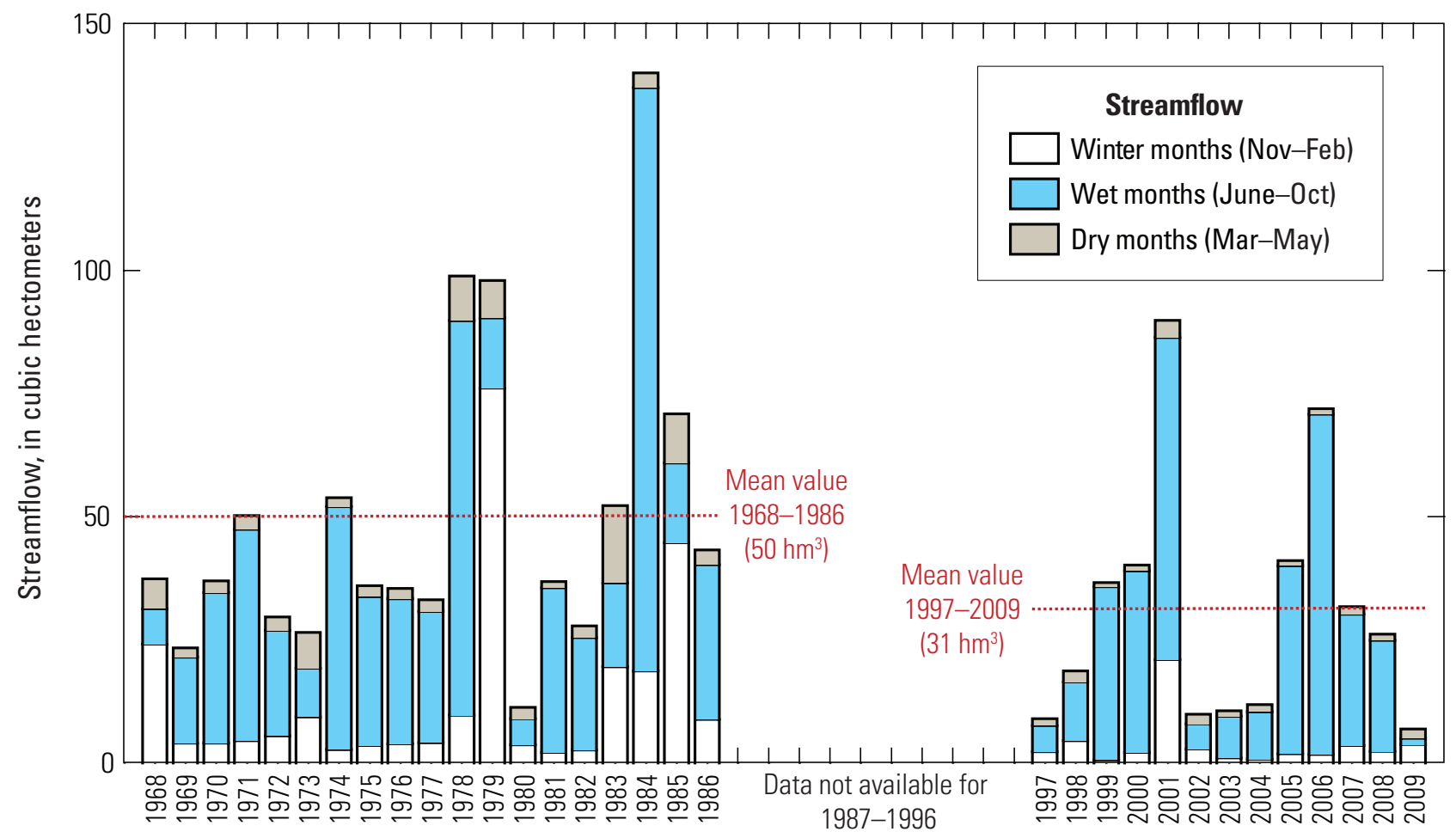

Water year

Figure 6. Bar graph showing annual streamflow, color-coded by season, as recorded at the gaging station San Pedro River near Tombstone, Arizona (09471550), for 1968-2009. 
is considered the quantity of groundwater that sustains streamflow during periods of no precipitation.

The rate of base flow is a function of recharge in the regional groundwater aquifer, rates of recharge in the stream alluvium aquifer (bank storage), the head gradients between the aquifer and stream, and the rates of groundwater withdrawals through both pumping from wells along the river and riparian ET. In reaches of the San Pedro River with intermittent streamflow, groundwater outflow through riparian ET affects the groundwater available for discharge as base flow. If the rate of riparian ET exceeds the rate of groundwater discharge as base flow, then base flow ceases.

Base flow can be separated from runoff by using various automated base-flow separation computer codes. Each of these methods has limitations when applied to streams that go to zero discharge (Kennedy and Gungle, 2010). Several methods have been used to estimate base flow for the San Pedro River within the Upper San Pedro Basin, and a comprehensive review and compilation of those estimates for the Tombstone gage is presented by Kennedy and Gungle (2010; table 3).

Base flow at the Tombstone gage was approximated from the 3-day low flow, which is calculated by averaging the three lowest consecutive daily streamflow values over the period of interest. Thomas and Pool (2006) used the 3-day low flow as an approximation of base flow at the Charleston gage because the 3-day low flow is repeatable and unbiased and is not dependent on any assumptions.

Base flow at the Tombstone gage was analyzed for the period 1968-1986 (early) and 1997-2009 (late). The Tombstone gaging station was not in operation for the intervening period. For each month, the 3-day low flow was calculated and converted to a monthly streamflow volume (in cubic hectometers). The annual base-flow volume was calculated by summing all of the monthly base-flow volumes from October through May. The summer months (June, July, August, and September) were excluded from the analysis because riparian ET uses all available groundwater in the vicinity of the Tombstone gage during this period. Streamflow during these months consists entirely of storm runoff.

Annual base flow of the San Pedro River at the Tombstone gage has declined over the period of record (fig. 9). The median base flow for the early period was $5.31 \mathrm{hm}^{3} / \mathrm{yr}$ and $2.74 \mathrm{hm}^{3} / \mathrm{yr}$ for the late period. The base flow during the winter months (November-February) showed the largest declines. The median winter and spring base flows each decreased by approximately 50 percent from the early to later period. Annual base flow during the early period ranged from $2.70 \mathrm{hm}^{3}$ in 1981 to $23 \mathrm{hm}^{3}$ in 1985. For the late period, annual base flow ranged from
Figure 7. Plot of average daily streamflow throughout the year at gaging stations on the San Pedro River in the middle San Pedro Watershed for the specified period of record.

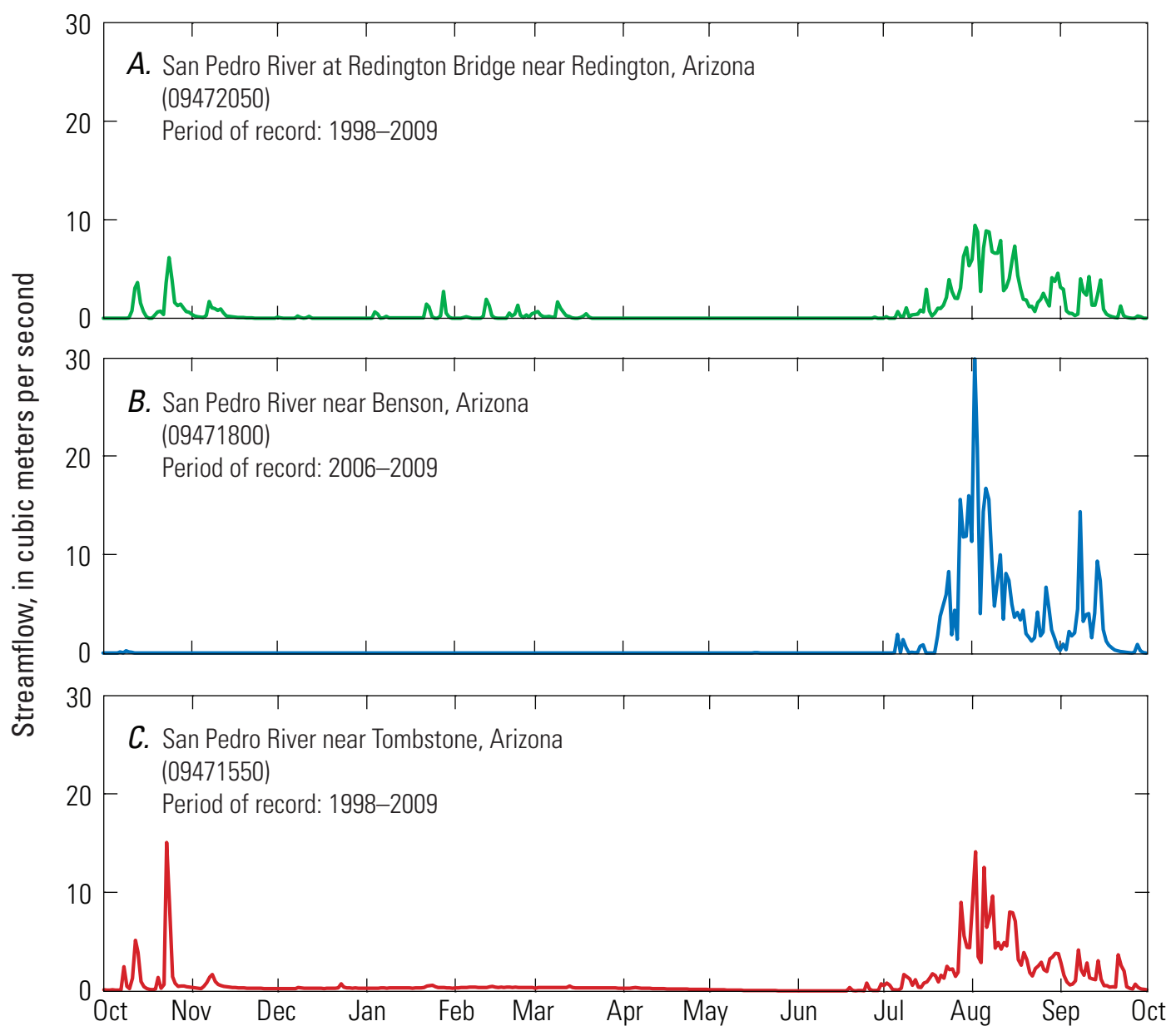


Table 3. Base flow discharge estimates at the Tombstone streamflow-gaging station. Values are in cubic hectometers per year.

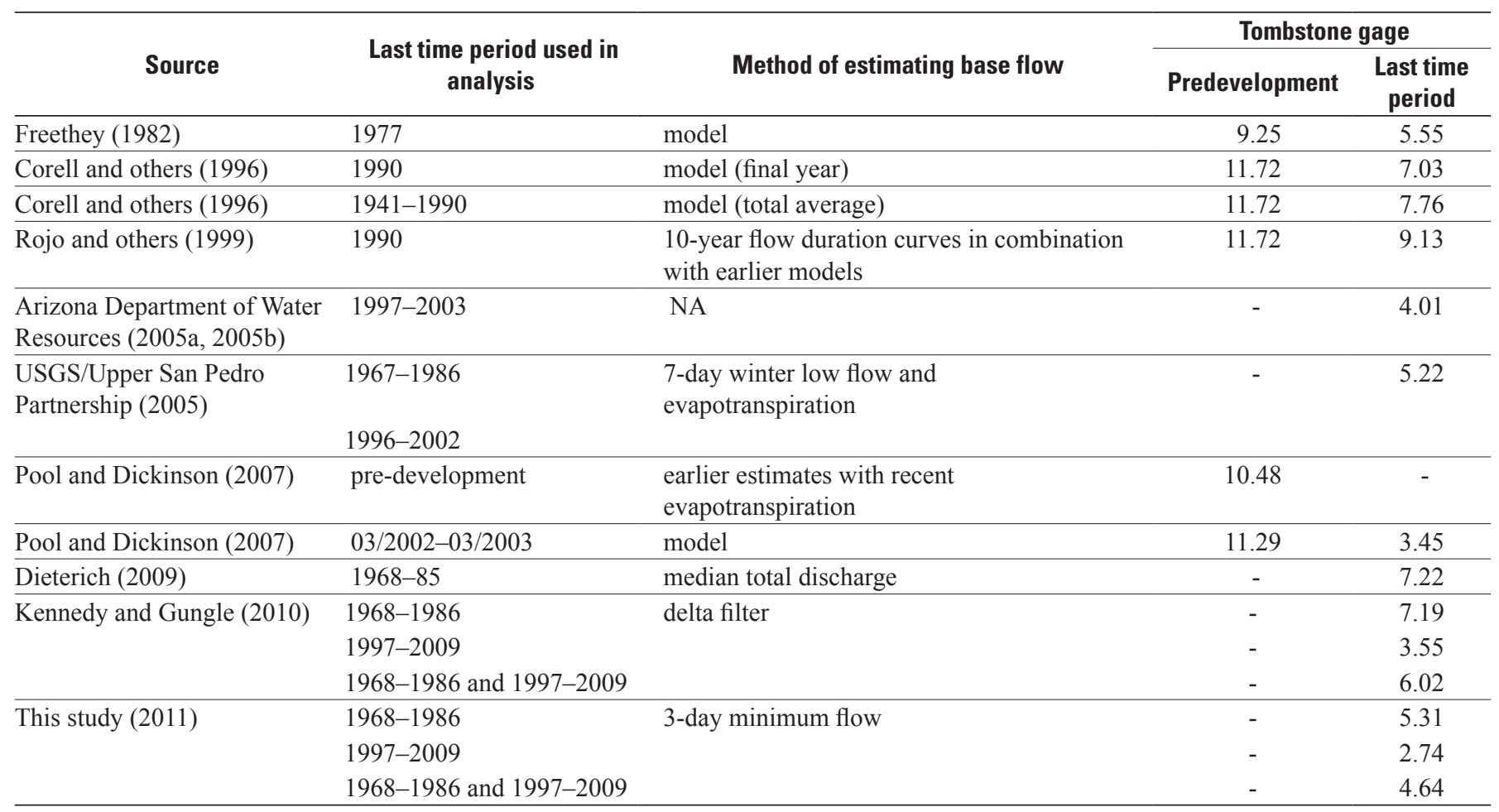

Table modified from Kennedy and Gungle (2010).

Figure 8. Bar chart of annual peak flows at the Redington and Charleston gaging stations, colored by the season during which greatest streamflow occurred.

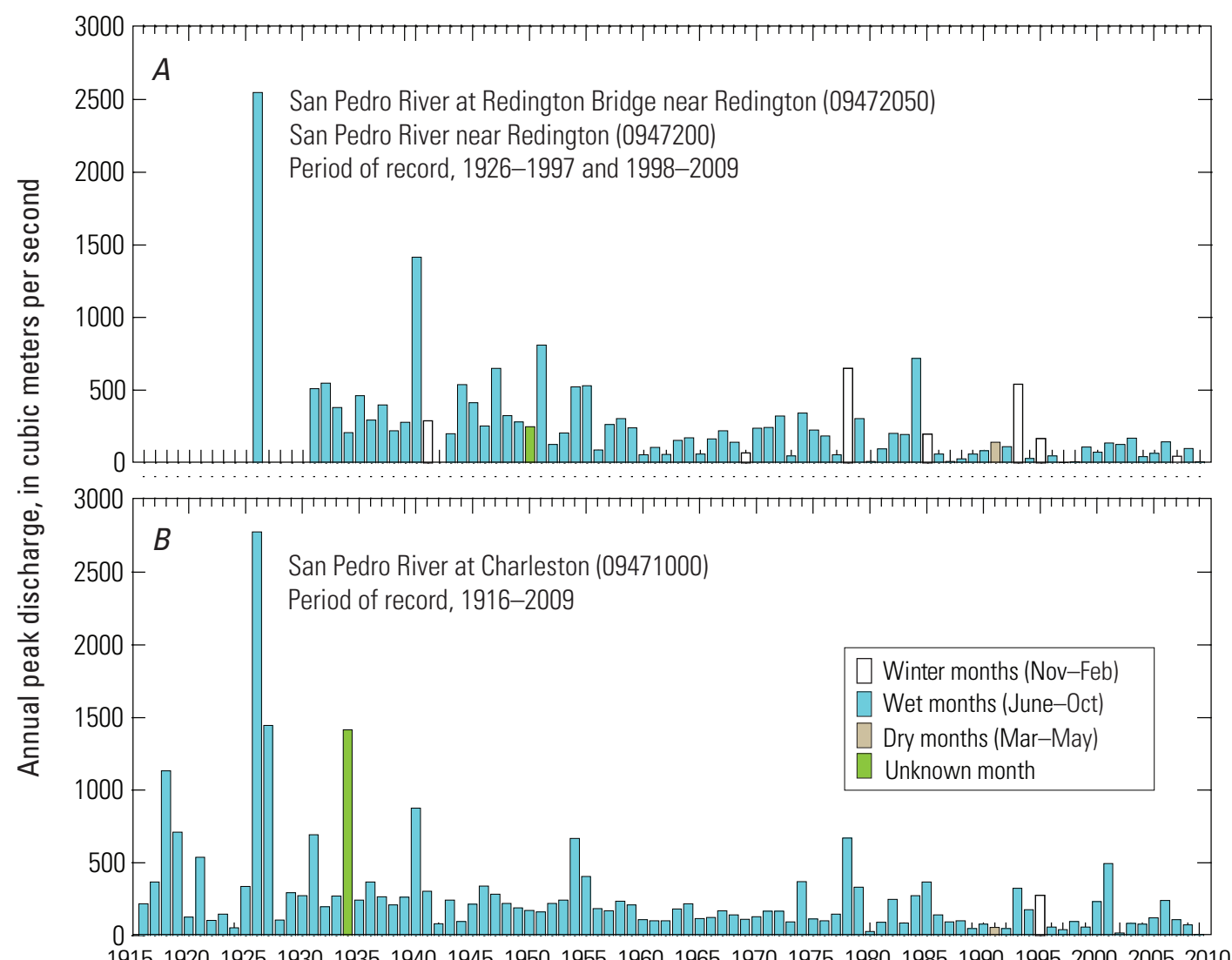

Water year 
$0.99 \mathrm{hm}^{3}$ in 1999 to $13 \mathrm{hm}^{3}$ in 2001 . The estimated monthly median base flow for the late periods show that for the months of October, November, and May, the median base flow has decreased to zero (fig. 10). The month of the largest base flow has also changed from January for the early period to February in the late period.

\section{Hydrogeology}

\section{Hydrogeologic Framework}

The primary aquifer of the middle San Pedro Watershed comprises permeable deposits of alluvium that overlie relatively impermeable crystalline rocks of pre-Cambrian and Tertiary age, Paleozoic limestone, Mesozoic sandstone and mudstone, and Tertiary prebasin sediments (Pool and Coes, 1999; Dickinson and others, 2010a). The distribution of the surficial permeable deposits is shown in figure 11. The alluvial aquifer is a sequence of unconsolidated to moderately well consolidated alluvial sediments of Late Tertiary and Quaternary age that is greater than $400 \mathrm{~m}$ thick in the center of the basin (fig. 12; Dickinson and others, 2010a). Rocks of the underlying bedrock are not important aquifers with the exception of the Paleozoic limestone, which recharges water locally. Stratigraphic units in the alluvial aquifer that are significant for groundwater flow (in ascending stratigraphic order) are the Miocene-Pliocene lower basin fill, Pliocene-Pleistocene upper basin fill, and Holocene alluvium along the San Pedro River. The basin fill is divided into lower and upper parts on the basis of geologic logs, drill logs, and sonic velocity logs (Pool and Coes, 1999). Lower basin fill forms the primary aquifer through which most groundwater flows. The upper basin fill is unsaturated across most of the basin, but is important because water infiltrates through the unit and recharges the water table during periods of runoff in ephemeral channels. The Holocene alluvium is a narrow stringer of highly permeable stream alluvium that is incised into the basin fill along the major stream channels (Hereford, 1993; Pool and Coes, 1999; Cook and others, 2009). The stream alluvium is an important local aquifer that drains the basin fill aquifer, receives streamflow infiltration, and stores water that supports riparian vegetation during periods lacking runoff (Pool and Coes, 1999).

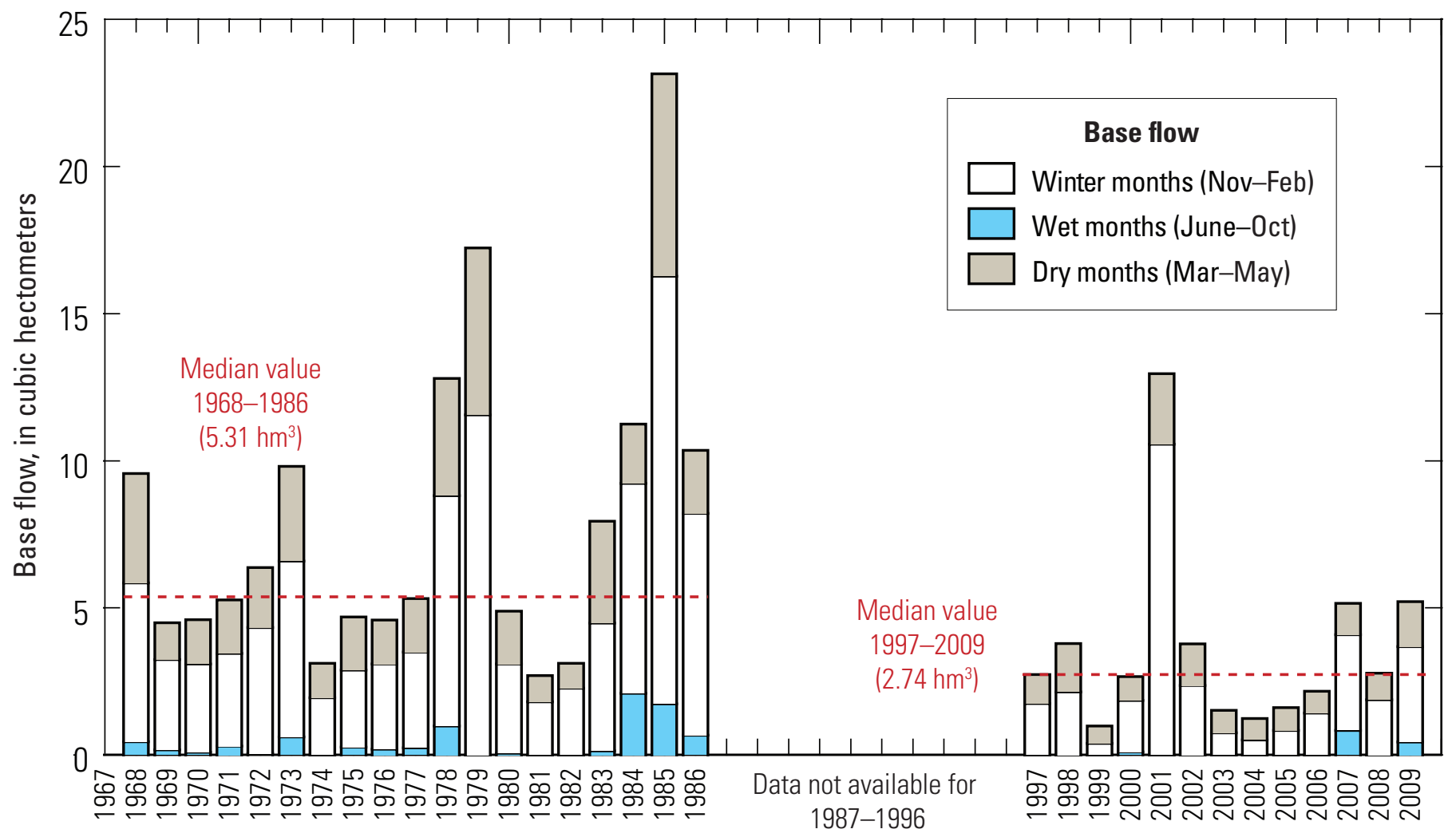

Water year

Figure 9. Bar chart of annual base flow at the San Pedro River near Tombstone, Arizona, streamflow gaging station (09471550), color coded by season. Base flow was not calculated for the months June through September. 
Figure 10. Bar chart of estimated median base flow at the Tombstone, Arizona, streamflow-gaging station for the early (1968-1986) and late (1997-2009) periods of record.
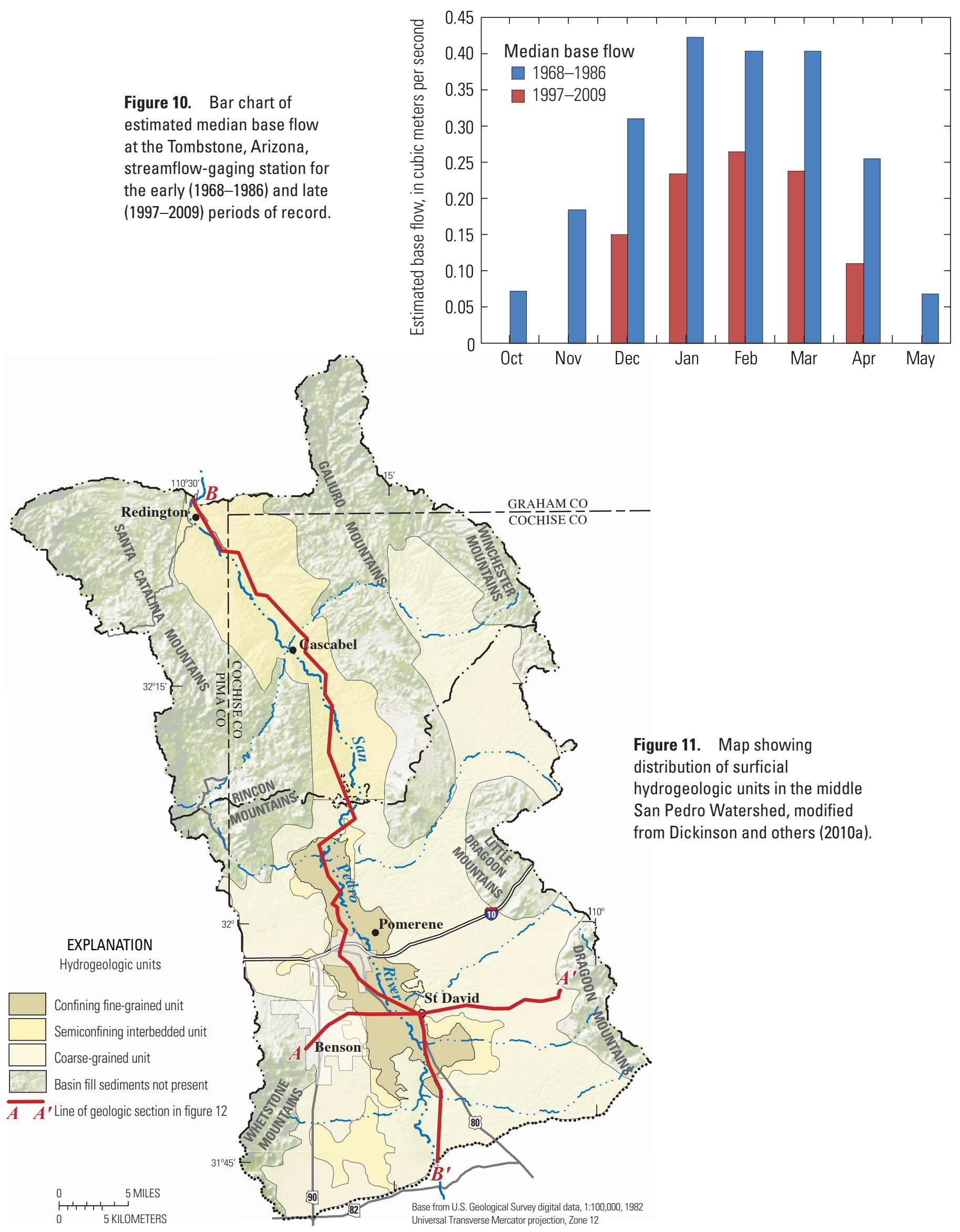

Figure 11. Map showing hydrogeologic units in the middle San Pedro Watershed, modified from Dickinson and others (2010a). 
The lower basin fill is divided into coarse- and fine-grained hydrogeologic units on the basis of lithology and electrical geophysical surveys (fig. 12; Dickinson and others, 2010a; 2010b). The coarse-grained unit of lower basin fill overlies bedrock, is the stratigraphically lowest water-bearing unit, and is present throughout most of the study area. It is commonly described in drill logs as conglomerate, decomposed granite, or sand and gravel with few silt and clay interbeds. A unit of fine-grained sediments within sand and gravel, interbedded between the fine-grained and coarse-grained units of the lower basin fill, is present along the outer margins of the fine-grained unit. The interbedded unit underlies the San Pedro River near St. David and extends southward towards areas of high bedrock. The fine-grained unit of lower basin fill includes small amounts of gypsum in a matrix of either silt and clay or mudstone, and few sand and gravel interbeds. At the basin center, a thick finegrained unit predominately consisting of silt and clay overlies the coarse-grained unit.
The aquifer system is unconfined along the basin margins and is confined or semi-confined in the basin center owing to the occurrence of the thick fine-grained unit of the lower basin fill (Dickinson and others, 2010a; 2010b). In the unconfined portion, the amount of water that can be extracted by pumping is controlled by the hydraulic connection between perforated well intervals and sediments that yield water by a lowered water table and drainage of pore spaces. Groundwater occurs under confined conditions beneath thick sequences of the fine-grained unit of the lower basin fill where lowering of the water level in wells results in little to no drainage of pore spaces within the thick fine-grained unit. Wells having artesian pressures are mostly near the San Pedro River between areas south of St. David to north of Pomerene (fig. 13), further indicating confined conditions. Near St. David and Pomerene, boreholes for deep wells commonly penetrated dry intervals of clay and silt up to $300 \mathrm{~m}$ thick before reaching saturated materials. Semi-confined conditions occur where sufficiently
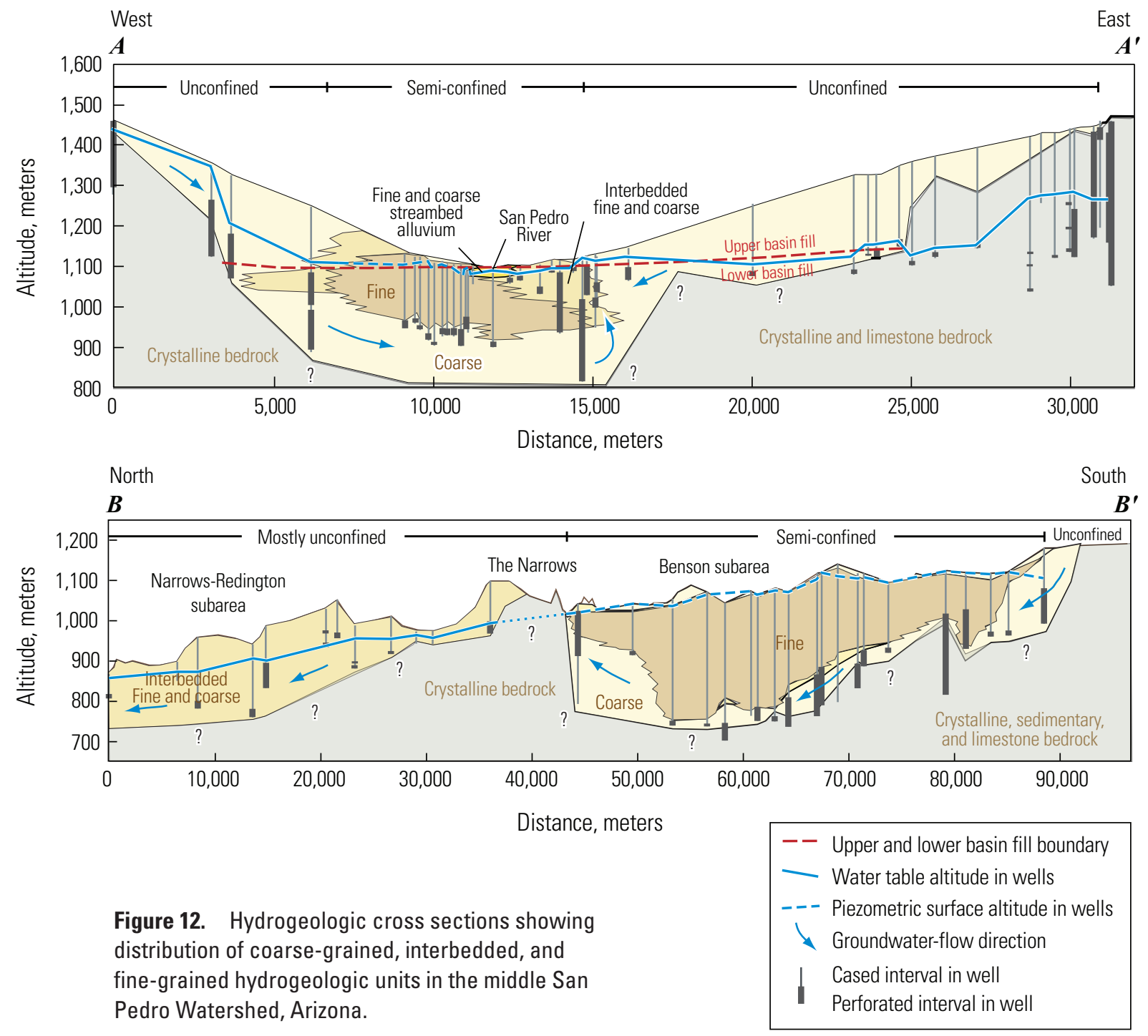


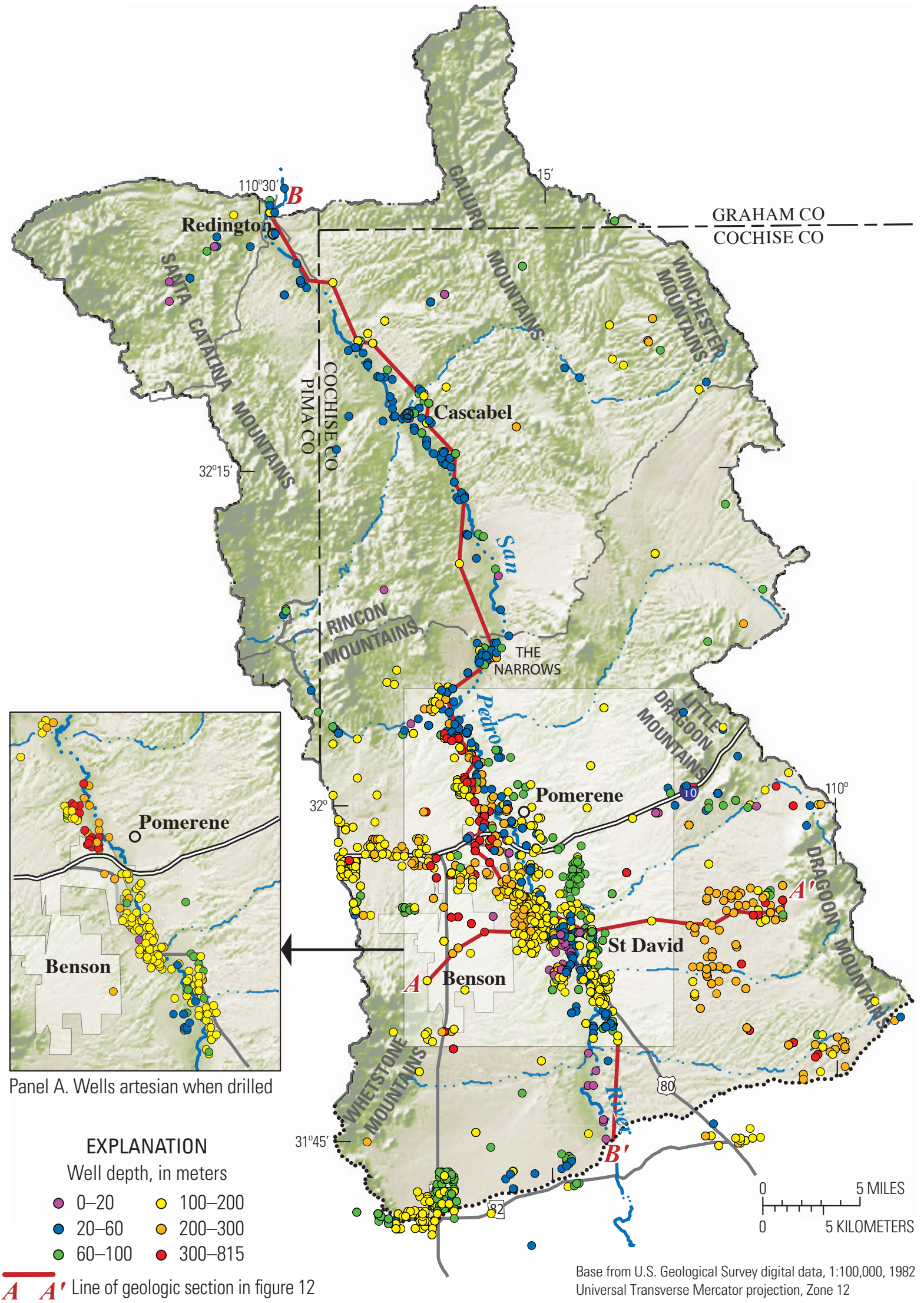

Figure 13. Map showing wells in the middle San Pedro Watershed for which lithologic logs are available, and (inset) wells having artesian conditions when drilled. 
thick fine-grained intervals result in delayed drainage of water from pore spaces in response to lowering of the water table. Semi-confined conditions occur at the margins of the intersection of the water table with the fine-grained unit of the lower basin fill.

\section{Groundwater}

Groundwater generally flows through the regional aquifer from recharge areas near the mountains toward the San Pedro River, where it either discharges to perennial reaches of the stream as base flow, is captured by pumping from wells, or is transpired by phreatophytes(Pool and Coes, 1999). Groundwater also enters the aquifer as underflow from the Sierra Vista Subwatershed, and leaves as underflow to the north of Redington into the Lower San Pedro Basin. Recharge near the mountains occurs by infiltration of precipitation through permeable rocks and fractures, and by infiltration of runoff in ephemeral channels. Water in the San Pedro River that enters from the Sierra Vista Subwatershed, as well as discharges to the stream as base flow in several reaches, and infiltrates back into the stream alluvium farther downstream along intermittent and ephemeral reaches. Some groundwater flowing toward the San Pedro River is intercepted upgradient from the river by wells and phreatophytes in areas of shallow groundwater along ephemeral streams.

Most groundwater flows through permeable sequences of sand and gravel in the coarse-grained unit of the lower basin fill and through the stream alluvium near the San Pedro River. In the Benson subarea, some flow occurs in saturated sequences of sand, gravel, and silt and clay interbeds in the upper basin fill. In the Narrows-Redington subarea, flow is generally through the lower basin fill because most of the upper basin fill has been removed by erosion (Dickinson, 2003). Groundwater flow through the Narrows between the subareas mostly occurs in saturated lower basin fill and stream alluvium that is continuous between the two subareas. In the Benson subarea, groundwater flows in the deep, coarsegrained unit under the thick sequences of silt and clay of the fine-grained unit at the basin center. Groundwater also flows through a shallow system of layers of sand and gravel in the Holocene stream alluvium. The fine-grained unit generally restricts vertical flow between the deep and shallow systems, but vertical flow does occur through discontinuous silt and clay layers in the interbedded unit along the margin of the finegrained unit. Groundwater from the deep system flows through the interbedded unit to the shallow system before discharging in areas near the San Pedro River. An area of vertical flow between the deep and shallow systems might be present along the San Pedro River near St. David, where the interbedded unit underlies the river and stream alluvium (fig.12).

Contours of water levels in 1940 (fig. 14; Freethey and Anderson, 1986) indicate horizontal variations in water levels and flow patterns in the groundwater flow system prior to development. The contours indicate a general pattern of groundwater flow from recharge areas near the mountains to discharge areas along the San Pedro River, some flow from the Upper San Pedro Basin to the Lower San Pedro Basin through the Narrows, and an overall northward component of flow. Along an east-west direction, groundwater levels are highest near mountain fronts, and lowest near the center of the basin. In the north-south direction, water levels are generally highest in the southern part of the Benson subarea and lowest in the northern part of the Narrows-Redington subarea. In the Benson subarea, groundwater flow from the Sierra Vista Subwatershed and upland areas converges toward the center of the basin. In the Narrows-Redington subarea, the groundwaterlevel altitude is uncertain near the mountain fronts because the water table is defined by fewer wells.

Groundwater levels and flow patterns have changed since predevelopment conditions mainly because of interception of groundwater by wells that would have discharged as base flow and because of long-term increases in ET by phreatophytes along the San Pedro River. Other changes are related to variation in the rates and distribution of recharge in areas of ephemeral channels near mountain fronts, changes in the timing and magnitude of seasonal flows in the San Pedro River, and entrenchment of the San Pedro River channel. Long-term water-level records for frequently measured wells indicate that there have been historical changes in storage, recharge, and discharge. In areas where groundwater has been developed, the records indicate changes in storage due to lowering of the water table in unconfined parts of the aquifer, and reductions in pressure and artesian levels in parts of the aquifer having confined and semiconfined conditions. Groundwater withdrawals have resulted in the reduction or cessation of artesian flow in many wells near St. David and Pomerene. In areas where groundwater withdrawals are negligible, interannual and interdecadal water-level changes are generally related to long-term temporal variations in natural recharge and discharge. These temporal changes in recharge and discharge are related to climate variability, variable ET rates (Thomas and Pool, 2006), and lowering of stream stages because of incision of stream channels (Hereford, 1993).

Changes in groundwater conditions were inferred from long-term water-level hydrographs selected to represent most of the study area (fig. 15), continuous hydrographs of recent water-level measurements near the San Pedro River, and changes in groundwater storage inferred by analyses of repeat absolute gravity measurements between St. David and the Whetstone Mountains. Long-term changes in water levels are evaluated by examining hydrographs from selected wells distributed throughout the watershed. Selection of wells for hydrograph analysis was based on the location of the well within the watershed, the availability of a well description, and the period of water-level record. Long-term water level and well construction data were obtained from the USGS National Water Information System (NWIS) database and the ADWR Groundwater Site Inventory and WELLS-55 databases (fig. 16). Recent changes in groundwater levels, 


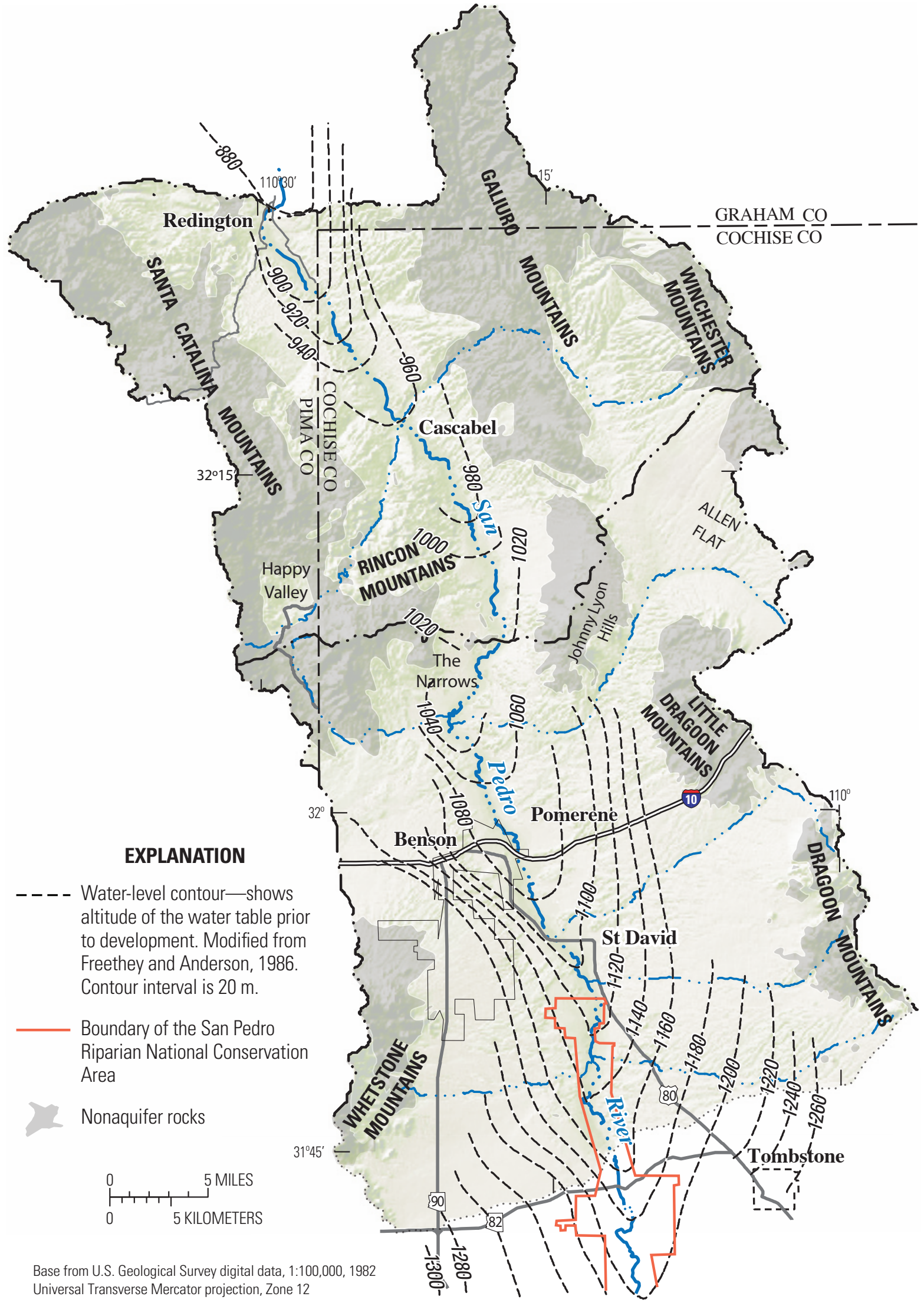

Figure 14. Map showing predevelopment water-level contours in 1940, modified from Freethey and Anderson (1986). 


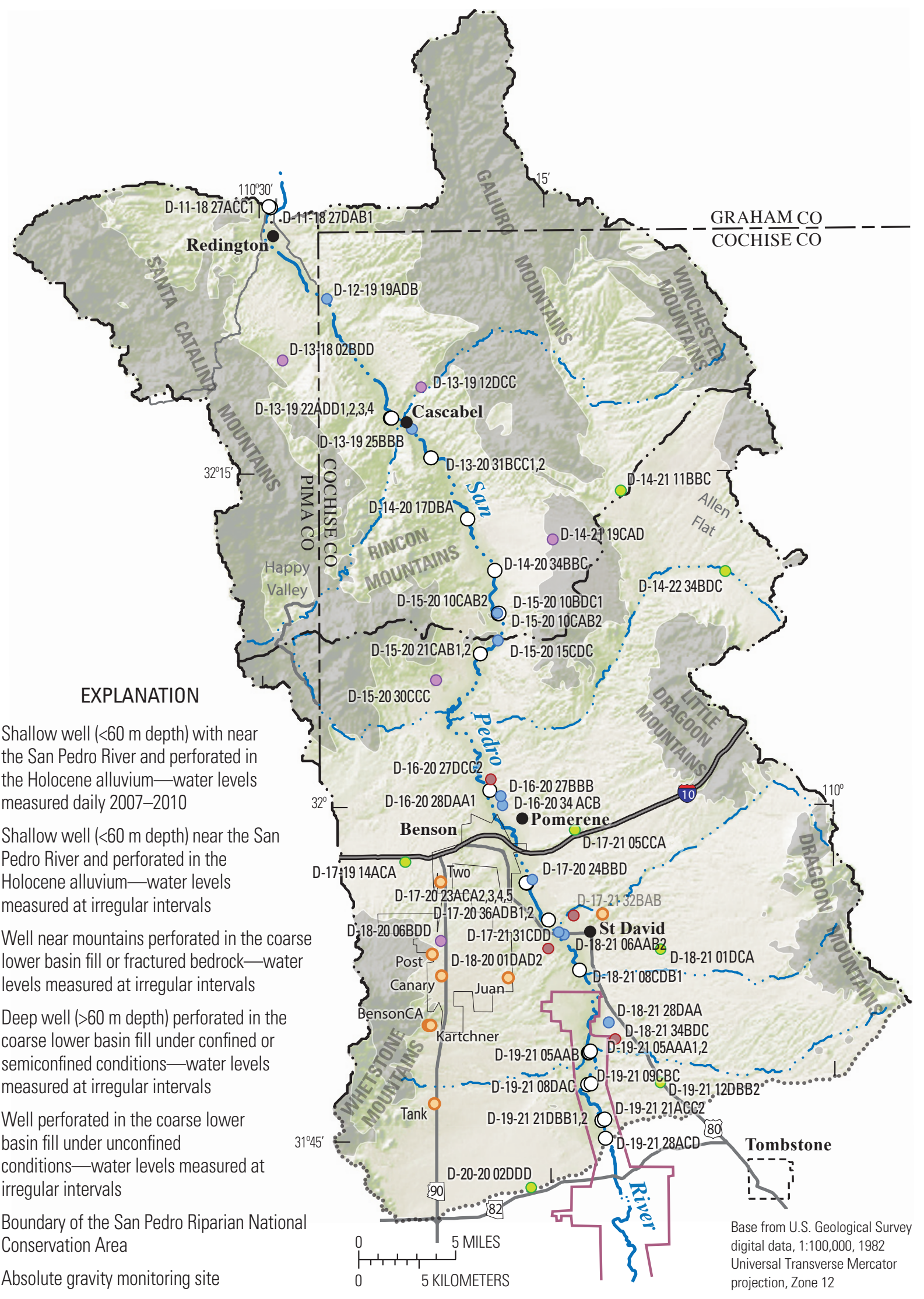
Tank

- Absolute gravity monitoring site

Figure 15. Map showing wells in which water levels were measured at daily and irregular intervals, and absolute gravity monitoring sites. 


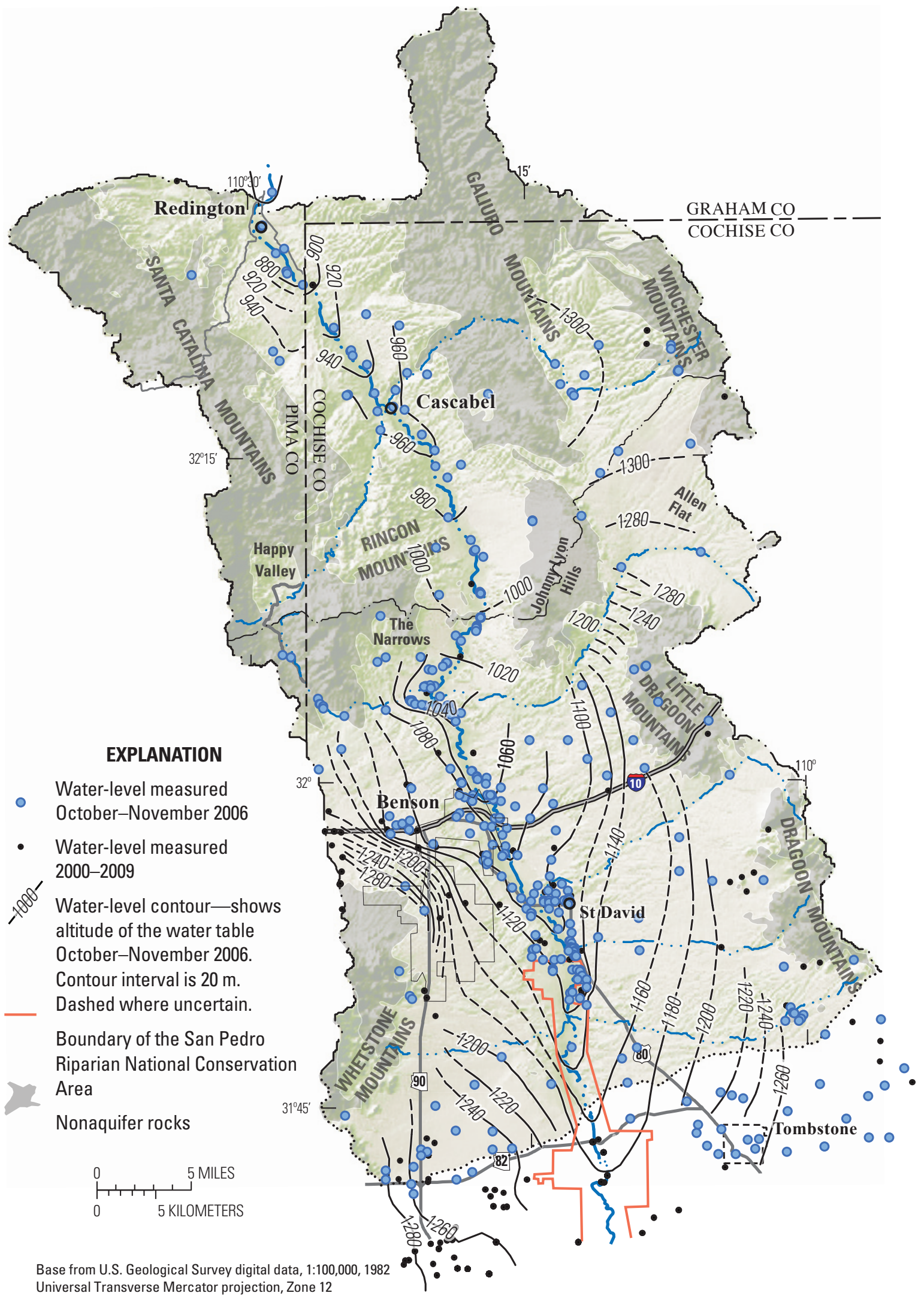

Figure 16. Map showing water-level contours for the period October-November 2006. Contours are constrained by additional water levels measured from 2000 to 2009. 
from January 2007 to September 2010, were inferred from water levels indicated by pressure transducers installed in 32 wells near the San Pedro River. The wells are all within $350 \mathrm{~m}$ of the river, range in depth from $3 \mathrm{~m}$ to $75 \mathrm{~m}$, and are perforated in Holocene stream alluvium. Daily water levels represent the average water level obtained at 30-minute intervals over a 24-hour period. Changes in groundwater storage were inferred from absolute gravity measurements at 7 sites between the Whetstone Mountains and St. David.

\section{Long-Term Changes in Groundwater Levels in Wells near Mountain Fronts}

Groundwater levels near the mountain fronts typically fluctuate in response to time-varying rates of recharge. These fluctuations are generally of greater magnitude than the natural changes in wells further from the mountains that are completed in the regional aquifer. Large water-level changes occur near areas of focused recharge in ephemeral channels and in areas near the mountain front with thin saturated sediments. The changes become smaller with greater distance from the mountain front and recharge areas, and with increasing transmissivity of the aquifer owing to thickening saturated sediments toward the center of the basin (Pool and Coes, 1999; Dickinson and others, 2004).

Long-term water level records (from 1950 to 2000) for five wells near the mountain fronts show considerable variation and within cyclical patterns. The largest changes occur in wells that are close to major drainages. The cyclical pattern appears as a repeating decline in water levels that rapidly returns to a higher level, which suggests that the water levels increase quickly during periods of increased recharge and decline gradually as
Figure 17. Plots of long-term waterlevel records for 12 wells that are either near mountain fronts or perforated in the coarse lower basin fill under unconfined conditions (continued on next page). Water level is defined as the altitude above sea level (in meters) using the National Geodetic Vertical Datum of 1929 (NGVD 29).

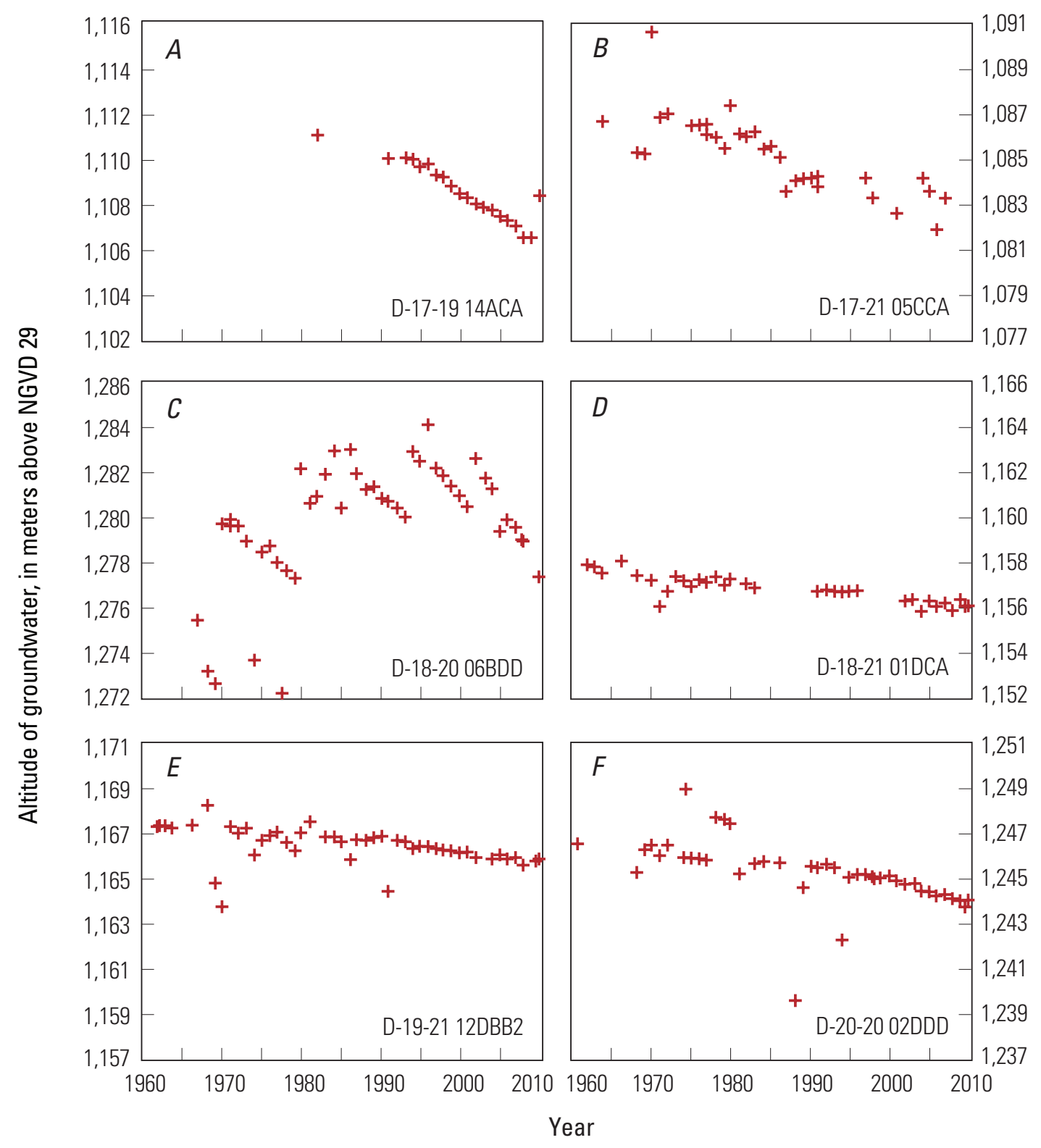


the water drains to the regional aquifer. The records of these mountain-front wells indicate that the cycle of the rising and falling pattern on these hydrographs lasts approximately 10 years and that recharge was greatest in the early 1980s and mid1990s. The magnitudes of the declines between the periods of recharge range from about $5 \mathrm{~m}$ in well D-13-18 02BDD to $3 \mathrm{~m}$ in well D-18-20 06BDD (fig. 17). Levels in well D-14-21 19CAD display an opposite pattern of gradual increases, separated by low levels between the years 1990-1996 (fig. 17). In this case, the low levels may reflect local groundwater withdrawals, but the large increases likely indicate a natural response of the water levels to periods of recharge. Water levels in well D-13-19 12DCC do not appear to vary within cyclical patterns despite the proximity of the well to an ephemeral channel (fig. 17). Levels in well D-15-20 $30 \mathrm{CCC}$ decline gradually, suggesting that the water levels are not influenced by nearby variations in recharge (fig. 17).

\section{Long-Term Changes in Groundwater Levels in Unconfined Parts of the Lower Basin Fill}

In general, long-term water-level records for wells that are perforated in the lower basin fill in unconfined conditions indicate declining or constant levels from 1960 to 2010 (fig. 17). In Allen Flat, well D-14-21 11BBC indicates little change in the water level, while well D-14-22 34BDC has an overall decline of approximately $7 \mathrm{~m}$ despite low water use in the area (Arizona Department of Water Resources, 2005). Declines of approximately $5 \mathrm{~m}$ between the years 1980 and 2008 in well D-17-19 14ACA may be related to groundwater withdrawals for municipal use by communities near Benson. The hydrographs for wells D-14-22 34BDC and D-17-21 05CCA indicate constant water levels or brief recoveries during the late 1980s and 1990s, which might be
Figure 17. Plots of long-term waterlevel records for 12 wells that are either near mountain fronts or perforated in the coarse lower basin fill under unconfined conditions. Water level is defined as the altitude above sea level (in meters) using the National Geodetic Vertical Datum of 1929 (NGVD 29).-Continued

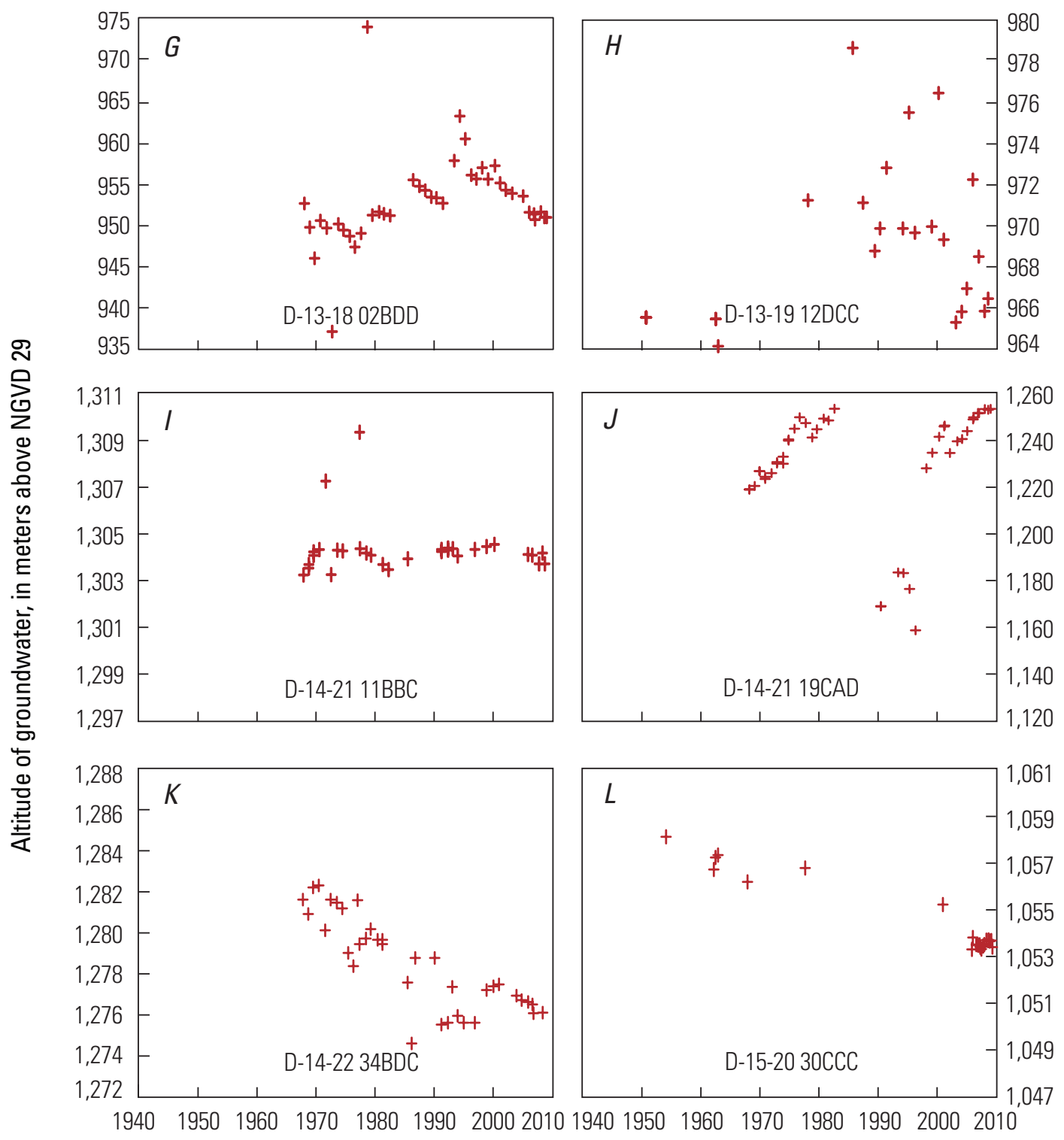


related to increased precipitation (fig. 5) and recharge during the early 1980 s and 1990 s that is indicated by several water level records for wells near the mountain fronts (fig. 17). The delay in these recoveries may be related to the time required for water from recharge events near the mountain fronts to reach the regional aquifer.

\section{Long-Term Changes in Groundwater Levels in Confined and Semiconfined Parts of the Lower Basin Fill}

Water level records in four wells completed in the confined part of the coarse lower basin fill generally declined from 1944 to 2010 (fig. 18). Declines in these wells likely are related to reduced pressures in the confined and semiconfined aquifer because of groundwater withdrawals for agriculture and municipal use. Near St. David, levels in well D-17-21 32BAB declined about $13 \mathrm{~m}$ from 1944 to 2010. In wells D-18-20

01DAD2 and D-18-21 34BDC, also near St. David, the levels decreased approximately $5 \mathrm{~m}$ and $7 \mathrm{~m}$, respectively, from 1945 to the mid- to late 1970s. The record for well D-18-20 01DAD2 indicates a brief recovery of approximately $3 \mathrm{~m}$ from 1980 to 1990, after which the record ends. The decline in well D-16-20 27BBB, north of Pomerene, is approximately $21 \mathrm{~m}$.

\section{Long-Term Changes in Groundwater Levels near the San Pedro River}

Long-term water levels in shallow wells near the San Pedro River have fluctuated interannually in response to periods of streamflow (fig. 19). Water levels from 1940 to 2010 recovered in response to increased streamflow, and declined when streamflow was less frequent. Entrenchment of the streambed since the early 1900s likely resulted in some water level declines of several meters near the river, similar to the amount of downcutting by the river, but data are not available to characterize this effect on the groundwater system. In wells D-12-19 19ADB, D-16-20 27DCC2, D-17-21

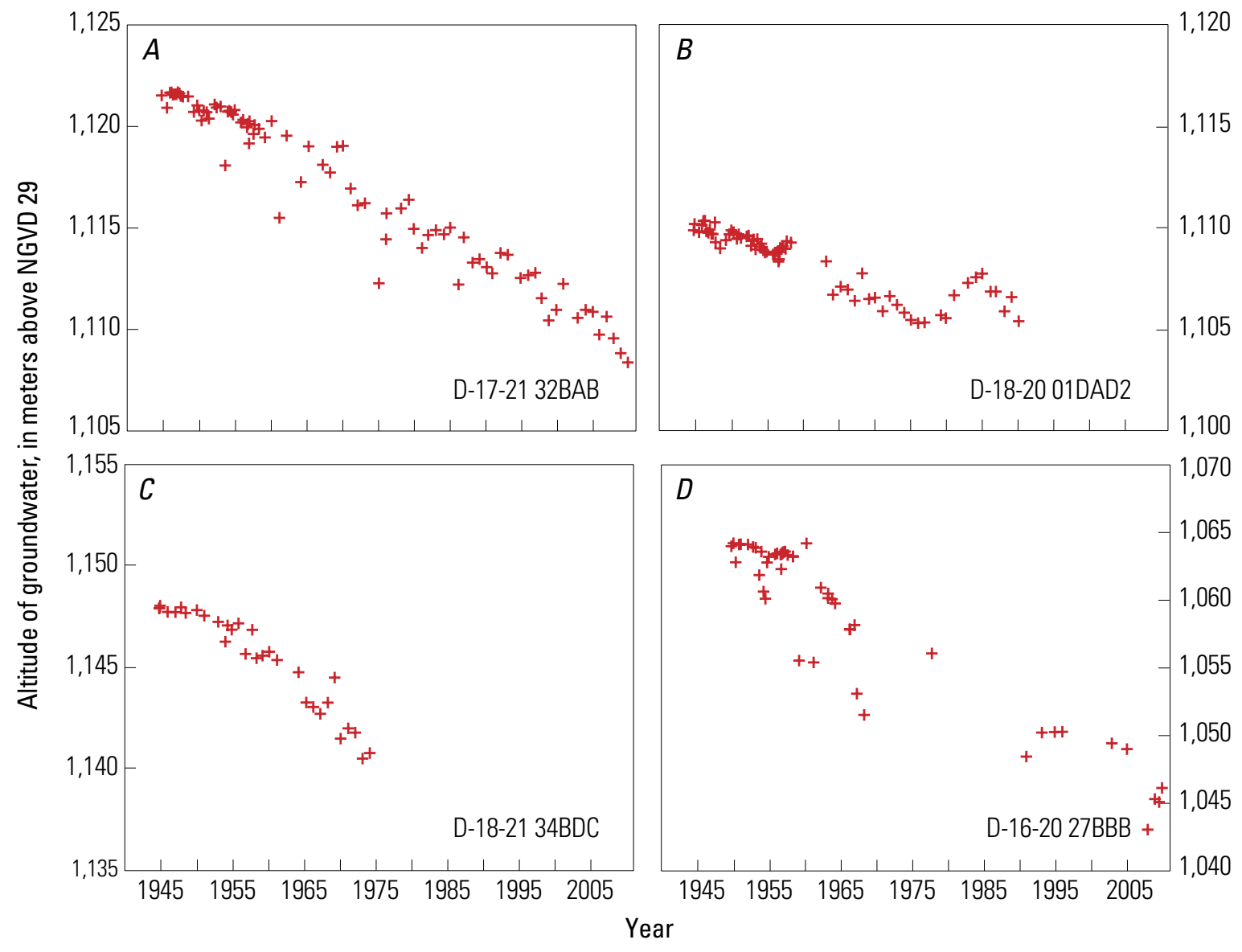

Figure 18. Plots of long-term water-level records in wells perforated in the coarse lower basin fill under confined or semiconfined conditions. Water level is defined as the altitude above sea level (in meters) using the National Geodetic Vertical Datum of 1929 (NGVD 29). 

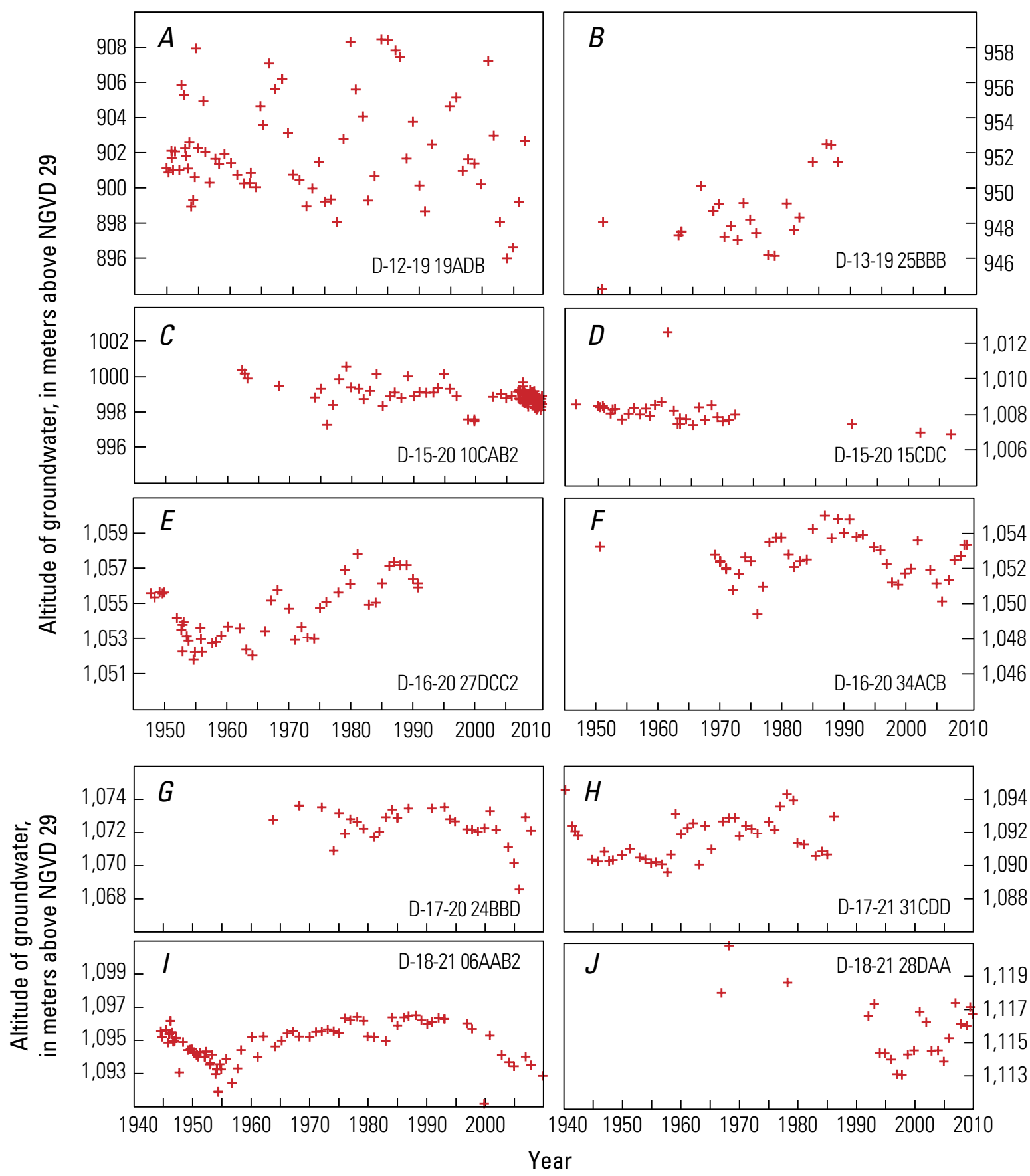

Figure 19. Long-term water-level records in 10 wells near the San Pedro River, all measuring less than $60 \mathrm{~m}$ in depth, and perforated in the Holocene alluvium. Water level is defined as the altitude above sea level (in meters) using the National Geodetic Vertical Datum of 1929 (NGVD 29). 
31CDD, and D-18-21 06AAB2, levels were lowest during periods of lower precipitation and base flow in the San Pedro River in the 1950s to mid-1960s (fig. 5). In these same wells, the mean water levels are generally several meters higher than other wells near the San Pedro River and the interannual fluctuations are larger after the mid-1960s. In well D-12-19 19ADB, between Cascabel and Redington, the fluctuations are as much as $10 \mathrm{~m}$ from the mid-1970s to the late 1980s. Higher water levels in wells D-13-19 25BBB, D-16-20 27DCC2, and D-16-20 34ACB in the 1980s may be related to periods of increased precipitation (fig. 5), base flow, and recharge as indicated by wells near the mountain fronts (fig. 17).

\section{Recent Changes in Groundwater Levels near the San Pedro River}

Changes in groundwater levels near the San Pedro River from 2007 to 2010 indicate seasonal variations in the rates of recharge and discharge to the river and in ET by phreatophytes and possibly some effects of withdrawals from wells (figs. 20-22). Previous evaluation of water-level variations in wells along the San Pedro River in the Upper San Pedro Basin by Leenhouts and others (2006) identified an annual pattern of two periods of high levels and two periods of low levels. The low levels occur during the warm and dry periods in the summer during June through July and in the dry periods in the fall from October to November. Low levels are related to high phreatophyte ET rates from March to November. High water levels occur during the warm and wet months in the summer (July through September) and the cool and wet months in the winter (January through April). High water levels in the summer result from infiltration of monsoon-event streamflow into the alluvium, and high levels in the winter are related to the lack of ET by phreatophytes as well as infiltration of runoffproducing winter precipitation. In some wells in the southern part of the study area, water levels reach a maximum early in the summer and do not respond to additional streamflow events, which suggest that any additional potential recharge cannot be stored in the aquifer.

The patterns in water-level fluctuations in wells near the San Pedro River in the San Pedro Riparian National Conservation Area (SPRNCA) generally appear in the hydrographs from wells in the middle San Pedro Watershed, but are less pronounced in downstream sites and differ in magnitude with time (figs. 20-21; Leenhouts and others, 2006). The hydrographs for wells in the southern part of the study area, near the SPRNCA, generally show a substantial decline in water levels of two or more meters from June to July, whereas levels in wells north of the Narrows declined two meters or less in this period. A large increase in water levels in all wells coincided with periods of relatively high flow in the San Pedro River from July to September, except for the summer months of 2009, when streamflow rates were low.

The direction of groundwater flow is determined by hydraulic gradient, measured by comparing water levels at two different horizontal or vertical locations. The downward movement of groundwater is indicated by a negative vertical gradient; the reverse is indicated by a positive vertical gradient. Vertical water-level gradients measured at several sites at which collocated wells were completed at different depths indicate that groundwater flow is generally downward and the San Pedro River is generally losing water to the subsurface (fig. 22). At the sites of wells D-13-20 31BCC1, -2 and D-13-19 22ADD1, -2, -3, and -4, the vertical gradient and groundwater recharge rates are largest during periods of summer streamflow; the gradient decreases and vertical flow diminishes to the lowest value in early summer, before the onset of summer streamflow events.

\section{Recent Changes in Groundwater Storage}

Changes in groundwater storage can be measured by using the temporal-gravity method, which is described in Kennedy and Winester (2011). Gravity data provide a direct measurement of subsurface mass, as explained by Newton's law of gravitation. If repeat gravity measurements are made, then changes in the force of gravity can reflect changes in subsurface mass, such as aquifer storage change (other processes that can cause subsurface mass change, such as active volcanism, are not present in the study area). If gravity measurements are made concurrently with water-level measurements at a well, an estimate of specific yield can be made.

A Micro-g Lacoste, Inc. A-10 absolute gravimeter was used to collect gravity data at seven monitoring sites in the middle San Pedro Basin between 2008 and 2010 (fig. 15; Kennedy and Winester, 2011). Five of the monitoring sites are near the base of the Whetstone Mountains (Two, Post, Canary, Benson CA, Tank), one monitoring site is midway between the Whetstone Mountains and the San Pedro River (Juan), and another is just north of the town of St. David (St. David) (fig. 15). Five measurements were made at most monitoring sites. Initial measurements were made in spring 2008, followed by quarterly measurements during 2010 . Gravity change was converted to aquifer storage change using a horizontal infinite slab approximation, by which $42 \mu \mathrm{gal}$ is equivalent to about $1 \mathrm{~m}$ of water (Telford and others, 1990).

At four of the seven monitoring sites (Tank, Juan, Benson CA, Post), gravity measurements (fig. 23) show little or no aquifer storage change between 2008 and 2010 when measurement uncertainty is considered (about $\pm 6 \mu \mathrm{Gal}$, or $145 \mathrm{~mm}$ water - for details see Kennedy and Winester, 2011). Post shows a small seasonal signal, typical of stations in semiarid environments where soil moisture varies. At the Canary monitoring site, a sizeable increase in aquifer storage between March 2008 and December 2009 is indicated by the gravity data, likely associated with recharge or storage in the unsaturated zone of winter rainfall during this period. Similar or larger amounts of rainfall during the summer in 2008, 2009, and 2010, however, did not result in an increase in aquifer storage at this or other monitoring sites. A similar but smaller 

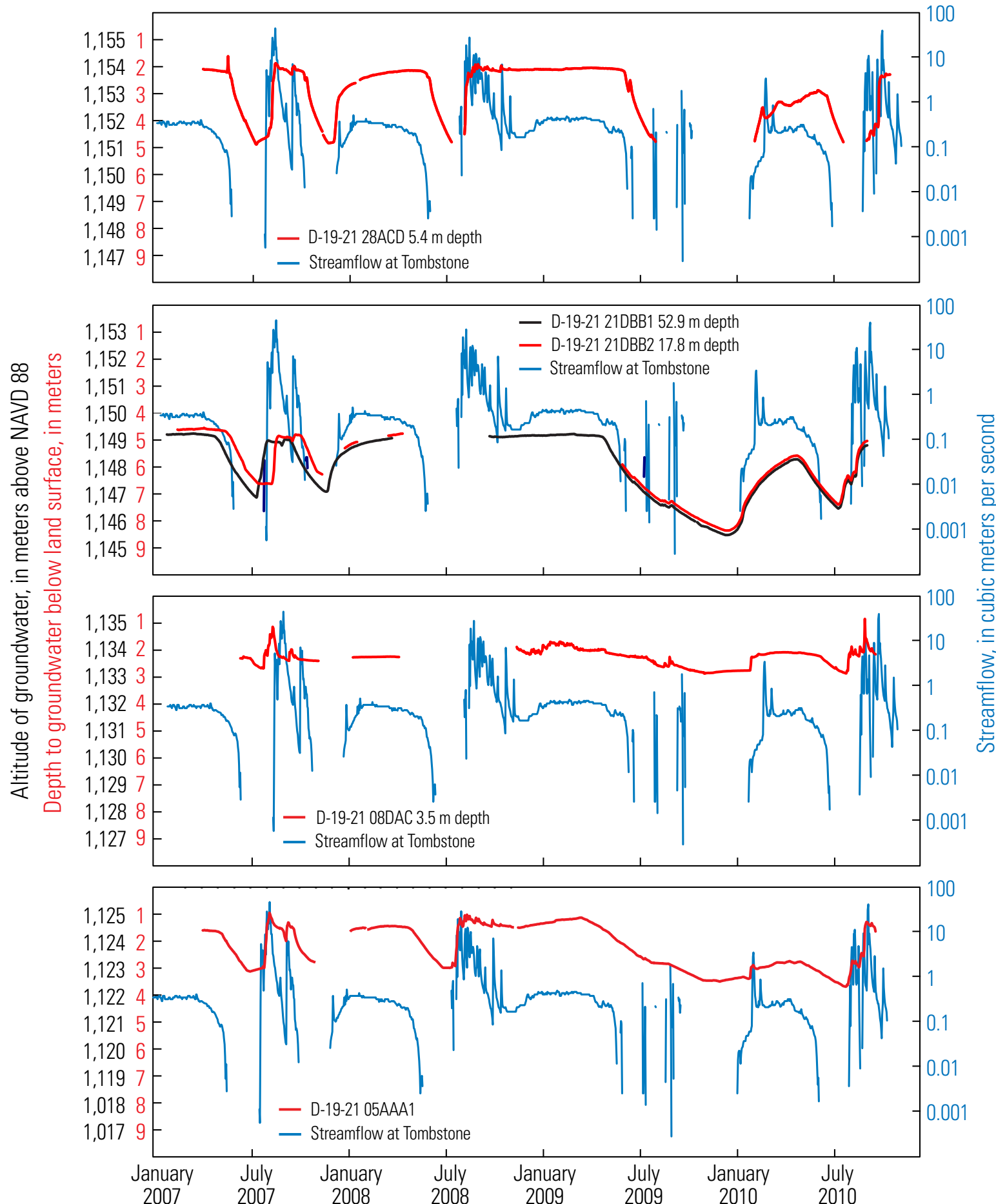

Figure 20. Plots of daily water levels in wells near the San Pedro River and streamflow at the gaging station San Pedro River near Tombstone, Arizona (09471550) from January 2007 to September 2010. Water level is defined as the altitude above sea level (in meters) using the North American Vertical Datum of 1988 (NAVD 88). 


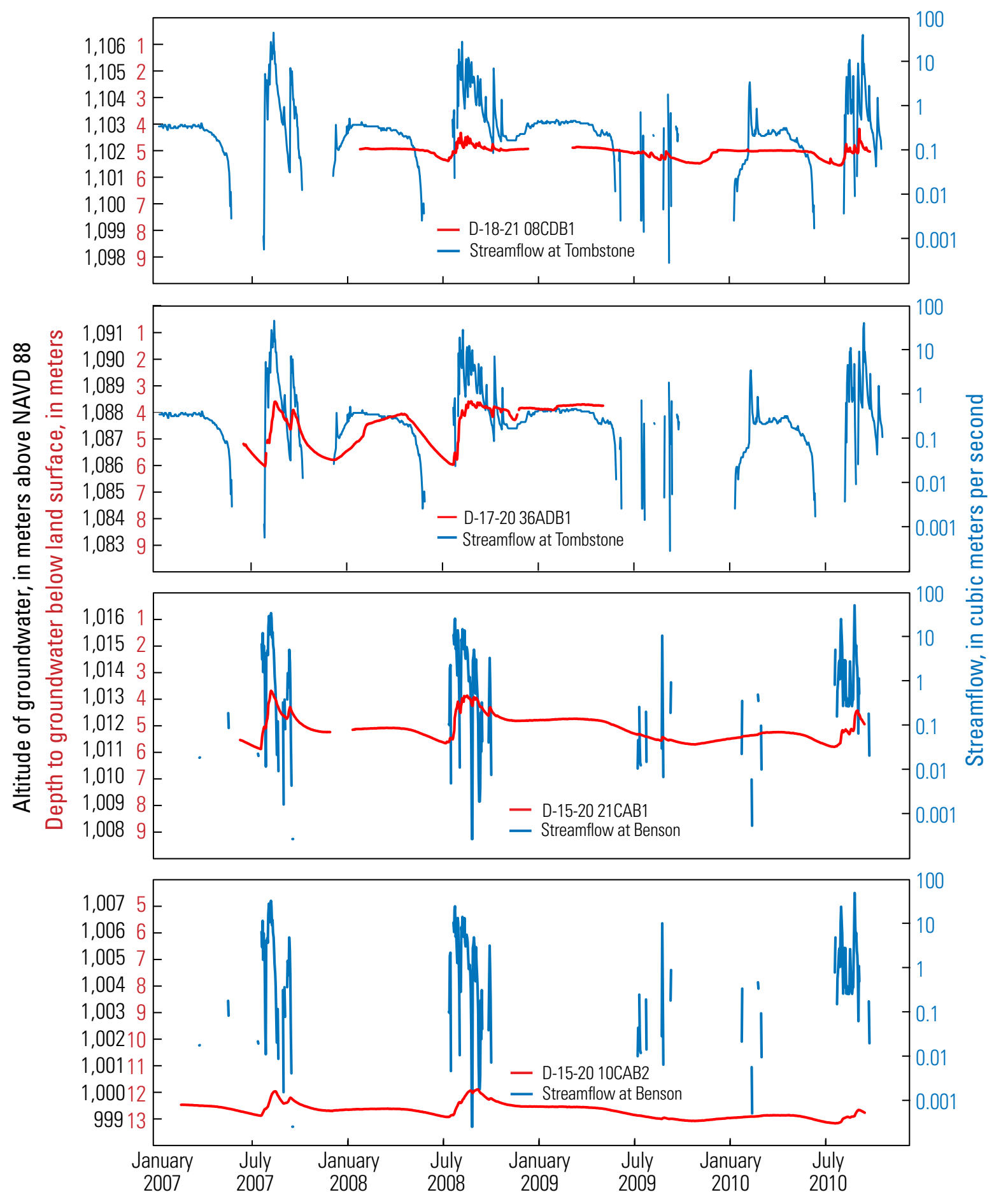

Figure 21. Plots of daily water levels in wells near the San Pedro River and streamflow at the gaging stations San Pedro River near Tombstone, Arizona (09471550) and San Pedro River near Benson, Arizona (09471800) from January 2007 to September 2010. Water level is defined as the altitude above sea level (in meters) using the North American Vertical Datum of 1988 (NAVD 88). 

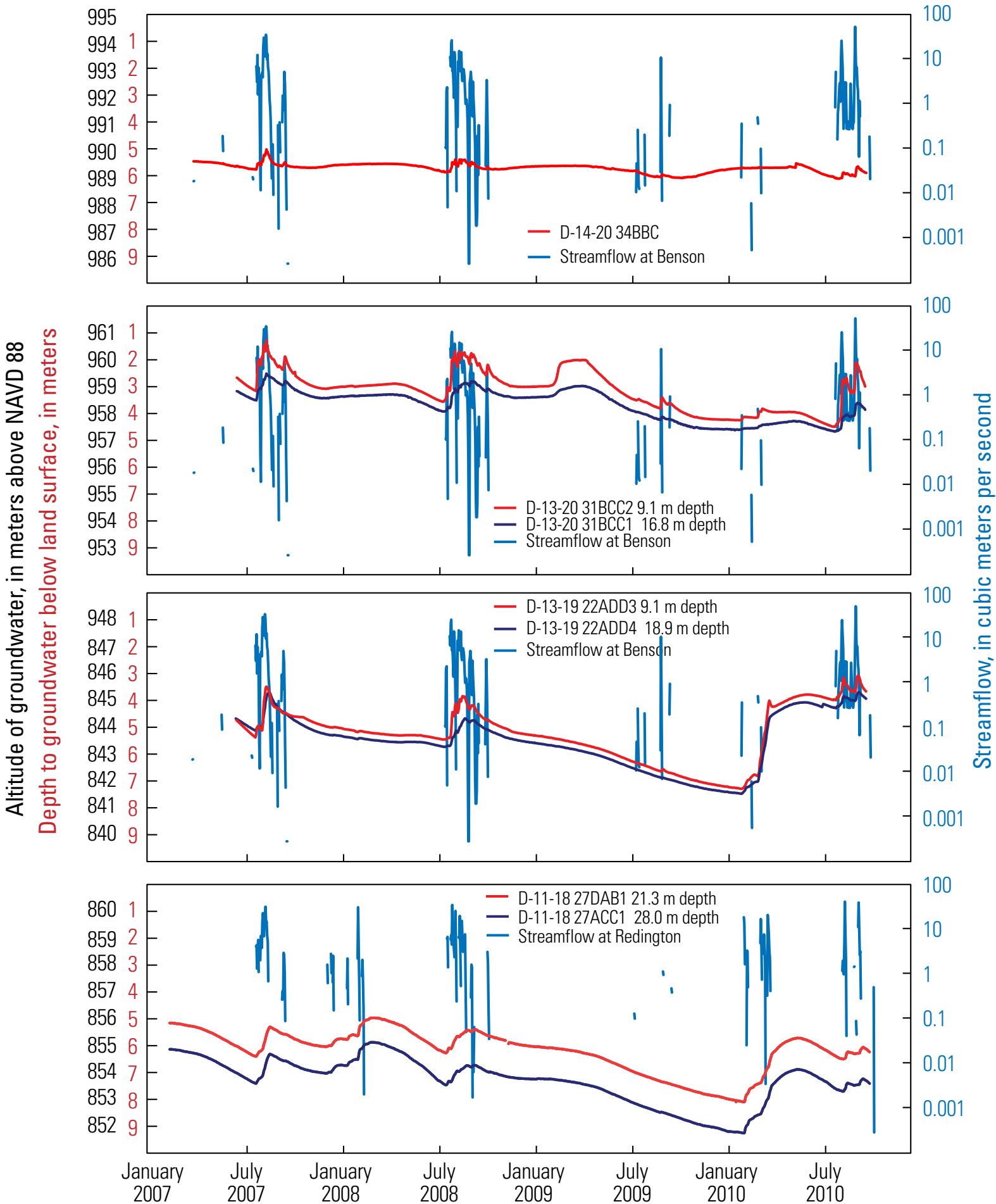

Figure 22. Plots of daily water levels in wells near the San Pedro River and streamflow at the streamgaing stations San Pedro River near Benson, Arizona (09471800) and San Pedro River at Redington Bridge near Redington, Arizona (09472050) from January 2007 to September 2010. Water level is defined as the altitude above sea level (in meters) using the North American Vertical Datum of 1988 (NAVD 88). 


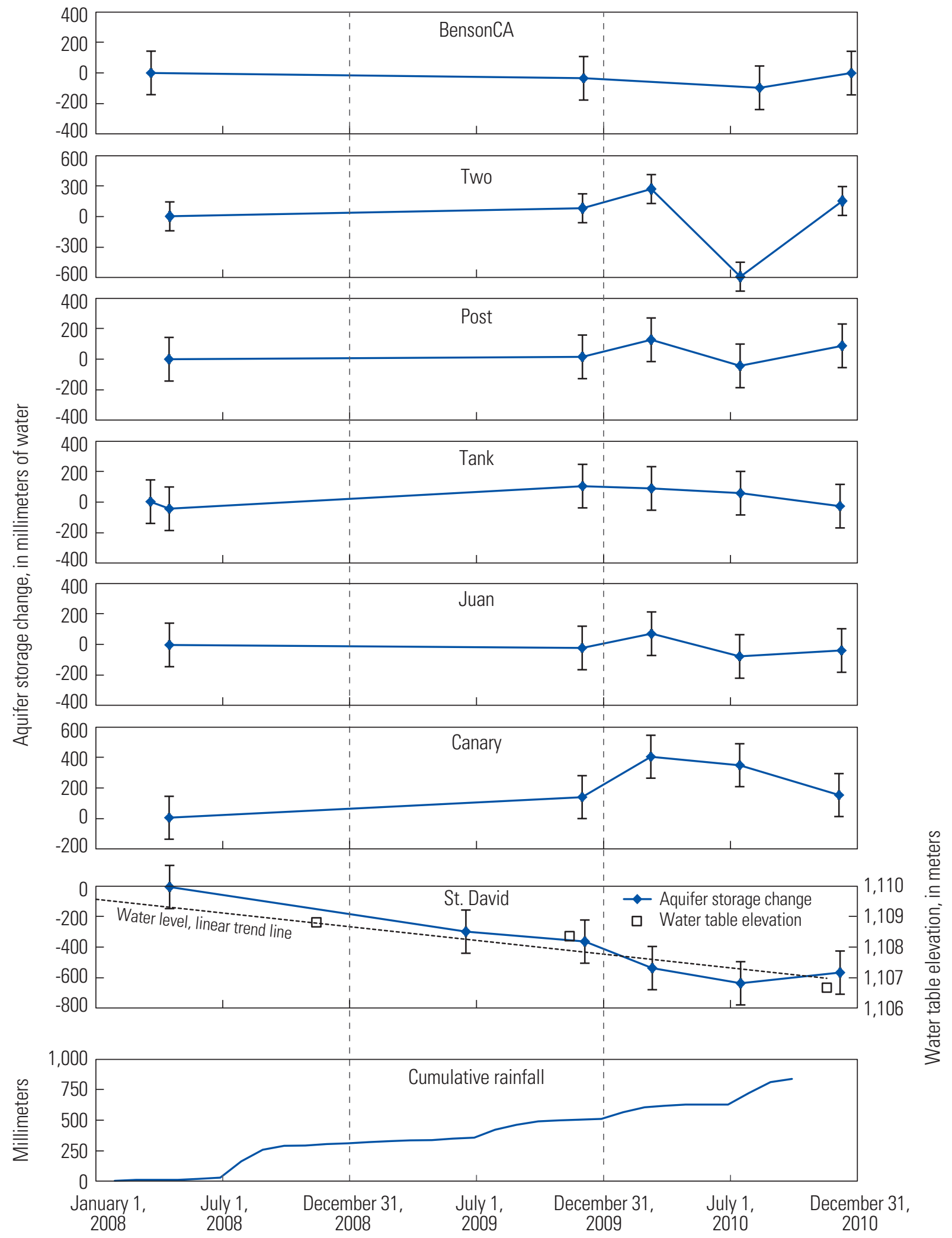

Figure 23. Plots of cumulative aquifer storage change and rainfall in the Benson subarea for 2008 through 2010. The graph for gravity monitoring site St. David also shows depth-to-water at a nearby well (D-17-21 32BAB) and a linear trend line fit to the depth-to-water data, which are used to calculate specific yield. 
increase in gravity values, and thus in aquifer storage, occurred at monitoring sites Juan, Two, and Post during this same period. Gravity measurements at the St. David monitoring site show a steady decline in aquifer storage of about $-240 \mathrm{~mm} /$ year when a linear trend is assumed (fig. 23). Water-level measurements at a nearby well, D-17-21 32BAB, about $700 \mathrm{~m}$ south-southeast of the gravity monitoring site, show a similar steady decline of about $-0.9 \mathrm{~m} /$ year. Dividing the linear trend of the change in water storage by the change in water level gives a specific yield equal to 0.27 , an average-to-high value for unconfined aquifers. This close correlation between gravity measurements and water-level change, and a relatively large gravity change, indicates unconfined conditions in the aquifer. St. David lies on the northeastern edge of fine-grained deposits in the center of the basin (Dickinson and others, 2010a), but on the basis of the present data these deposits do not appear to extend to the vicinity of the well and gravity monitoring site.

Gravity measurements at monitoring site Two indicate relatively little storage change with the exception of one low measurement in July 2010 (fig. 23). A likely explanation for the low measurement is depressed water level caused by pumping from one or more production wells located just north of the gravity station. A subsequent measurement, in December 2010, was nearly equal to the two measurements prior to the one in July, indicating that any storage change associated with nearby pumping was not a long-term change.

\section{Groundwater Budgets}

A groundwater budget is based on the principle that the rate of change in the volume of water stored in an accounting unit such as an aquifer is equal to the rate at which water flows into the aquifer minus the rate at which water flows out of the aquifer (Healy and others, 2007). Water budgets provide a basis for assessing this rate of change, and in particular, how a natural or human-induced change in one part of the hydrologic cycle may affect other aspects of the cycle (Healy and others, 2007). A groundwater budget is an accounting of the inflow to, outflow from, and storage change in an aquifer for a select time period (Hollett and others, 1991). In a groundwater budget, if the inflows and outflows are equal, the groundwater system is said to be in equilibrium. If the inflows and outflows in an aquifer are not equal then the aquifer is in a transient condition, and the change in the volume of groundwater storage is manifested in changing water levels. Calculation of a groundwater budget can indicate whether aquifer storage is declining, gaining, or stable and can provide a better understanding of the movement of groundwater; this information is needed to make informed water-management decisions.

Groundwater budgets were developed for the Benson and Narrows-Redington subareas for predevelopment conditions (prior to 1940) and recent conditions (2001-2009). Groundwater inflows into the middle San Pedro Watershed consist of underflow from the Sierra Vista Subwatershed, recharge from infiltration along ephemeral channels, recharge from infiltration through permeable rocks and sediments within and near the mountain fronts as well as through sediments along the San Pedro River, and incidental recharge from irrigation. The quantity of groundwater underflow from the Sierra Vista Subwatershed was estimated in simulations made with the existing groundwater-flow model (Pool and Dickinson, 2007). Infiltration along the San Pedro River was calculated as the difference in the streamflow volumes at upstream and downstream gaging stations. Groundwater recharge was estimated by simulations made with a distributed-parameter water balance model (BasinCharacterization Model, BCM; Flint and Flint, 2007) and a regression equation between recharge and precipitation for alluvial basins in southern Arizona (Anderson and others, 1992). The BCM was developed as part of a larger study of the processes, properties, and climate factors affecting groundwater recharge and runoff variability in the arid and semiarid southwestern United States (Flint and Flint, 2007). Incidental recharge was estimated from groundwater withdrawals for irrigation and irrigation system efficiencies.

Groundwater outflows from the middle San Pedro Watershed include withdrawals at wells, loss through ET by phreatophytes, discharge to the channel of the San Pedro River, and underflow to the Lower San Pedro Basin north of Redington. Data on historical and recent groundwater withdrawals were compiled from previous reports and from municipal water company and industry records. Surface-water diversions at the St. David ditch and Pomerene canal were compiled from Putman and others (1988). Agricultural water use from 2006-2009 was estimated by field verification of crop type, area of irrigated acreages, irrigation efficiency, and the modified Blainey-Criddle formula as described by the Bureau of Reclamation (1992, appendix A). Evapotranspiration by phreatophytes was calculated for the period 2000 to 2009 using remote sensing data and estimates from Freethey and Anderson (1986) for predevelopment conditions. Underflow to the Lower San Pedro Basin was determined by calculating the residual in the water budget of the Narrows-Redington subarea. The changes in groundwater storage in both subareas were calculated as the residual after subtracting the inflows from the outflows of the groundwater budget.

Groundwater budgets for water years 2001-2009 for the Benson and Narrows-Redington subareas are presented at the end of this section. This period was selected because all of the major components of the water budget were available for these years. All groundwater budget components are summed by water year with the exception of the water-use components, which are compiled by calendar year because the U.S. Census data on which they are based are compiled by calendar year.

The following sections describe the methods used to estimate natural recharge, withdrawals from wells, and through ET by phreatophytes, and streamflow seepage components of the groundwater budget. The average (1940-2009) annual natural recharge component was used in calculating the groundwater budget to reduce anomalies caused by short-term variability in climate. 
Table 4. Predevelopment groundwater budgets for the Benson and Narrows-Redington subareas modified from Anderson and Freethey (1995).

[Abbreviation: $\mathrm{hm}^{3} / \mathrm{yr}$, cubic hectometers per year]

\begin{tabular}{|c|c|c|c|c|}
\hline \multirow{2}{*}{ Water-budget component } & \multicolumn{2}{|c|}{$\begin{array}{l}\text { Benson } \\
\text { subarea }\end{array}$} & \multicolumn{2}{|c|}{$\begin{array}{c}\text { Narrows-Redington } \\
\text { subarea }\end{array}$} \\
\hline & $\begin{array}{l}\text { Inflow } \\
\left(\mathrm{hm}^{3} / \mathrm{yr}\right)\end{array}$ & $\begin{array}{l}\text { Outflow } \\
\left(\mathrm{hm}^{3} / \mathrm{yr}\right)\end{array}$ & $\begin{array}{l}\text { Inflow } \\
\left(\mathrm{hm}^{3} / \mathrm{yr}\right)\end{array}$ & $\begin{array}{l}\text { Outflow } \\
\left(\mathrm{hm}^{3} / \mathrm{yr}\right)\end{array}$ \\
\hline $\begin{array}{l}\text { Mountain-front and } \\
\text { ephemeral channel recharge }\end{array}$ & 20.5 & 0.0 & 13.3 & 0.0 \\
\hline $\begin{array}{l}\text { Stream baseflow leaving } \\
\text { subarea }\end{array}$ & 0.0 & 6.7 & 0.0 & 7.2 \\
\hline $\begin{array}{l}\text { Evapotranspiration by } \\
\text { phreatophytes }\end{array}$ & 0.0 & 12.3 & 0.0 & 6.9 \\
\hline Groundwater underflow $^{1}$ & 0.0 & 1.5 & 1.5 & 0.7 \\
\hline Groundwater storage & 0.0 & 0.0 & 0.0 & 0.0 \\
\hline Total & 20.5 & 20.5 & 14.8 & 14.8 \\
\hline
\end{tabular}

${ }^{1}$ Value from this study.

\section{Benson Subarea and Narrows-Redington Subarea Predevelopment Groundwater Budgets}

The predevelopment groundwater budgets for the Benson and Narrows-Redington subareas are based on previous work by Anderson and Freethey (1995), who compiled predevelopment groundwater budgets for several alluvial basins in Arizona. The boundaries of the Benson subarea are similar to their "Benson Basin" and are used for this report. The total annual predevelopment discharge from the Benson subarea is approximately $20.5 \mathrm{hm}^{3} / \mathrm{yr}$ (table 4). The groundwater budget developed by Anderson and Freethey (1995) for the Lower San Pedro Basin extends from the Narrows to the confluence of the San Pedro and Gila Rivers. Their groundwater budget was modified for the boundaries of the Narrows-Redington subarea as we have defined it. The total annual predevelopment discharge from the Narrows-Redington subarea is approximately $14.8 \mathrm{hm}^{3} / \mathrm{yr}$ (table 4) and it is assumed that the quantity of recharge as defined by Anderson and Freethey (1995) as "Stream Base flow Leaving (the Benson) Subarea" into the Narrows-Redington subarea is included in the "MountainFront and Ephemeral Channel Recharge."

\section{Groundwater Recharge}

In the middle San Pedro Watershed, groundwater is recharged by infiltration and percolation of precipitation and snowmelt in bedrock mountains (mountain-block recharge or MBR), seepage of runoff within stream channels that emerge from the mountains and flow onto the unconsolidated basin fill (mountain-front recharge or MFR), infiltration of streamflow from the San Pedro River, northward lateral groundwater flow from the Sierra Vista Subwatershed to the south, and incidental recharge from irrigation. The contribution of recharge to the aquifer from infiltration and percolation of precipitation on the basin fill is considered minimal (Coes and Pool, 2007) and was not included in the groundwater budget.

\section{Mountain-Front and Mountain-Block Recharge}

Groundwater in the middle San Pedro Watershed moves from recharge areas near the mountains and flows through the basin-fill aquifer, where it may be discharged to perennial reaches on the San Pedro River or is withdrawn by riparian ET (fig. 24). Quantifying the rates and locations of MFR and MBR is difficult because the water available for MFR and MBR is controlled by precipitation, evaporation rates, streamflow and runoff, and the permeability of exposed rocks in mountains and materials in the unsaturated zone.

The first basin-scale estimates of natural recharge in the San Pedro Valley were developed as part of the Southwest Alluvial Basins Regional-Aquifer System Analysis (SWAB RASA) study in the mid-1990s. As part of that study, groundwater budgets were developed on the basis of available data, and where information was lacking, a regression equation between the annual recharge and precipitation was developed (Anderson and others, 1992). These estimates of recharge were later incorporated into numerical groundwaterflow models (Anderson and Freethey, 1995).

Investigations of MFR and MBR in the San Pedro Valley have been focused on areas in the Upper San Pedro Basin to the south. In the middle San Pedro Watershed, estimates of MFR and MBR have not been the primary focus in previous investigations. As part of a larger project to better understand the hydrology of the Sierra Vista Subwatershed, Coes and Pool (2005) estimated infiltration along ephemeral stream channels using chloride, tritium, and stable-isotope data. The contribution of recharge to the aquifer from infiltration and percolation of precipitation on the basin fill is considered minimal (Coes and Pool, 2005) and was not included in the groundwater budget.

The timing and areas of recharge were investigated by Hopkins (2014), who collected water samples from wells, the San Pedro River, and precipitation in the middle San Pedro Watershed to describe movement of groundwater and residence times using solute and isotope geochemistry. Hopkins found evidence that winter precipitation contributes to recharge in the fracture system and the unconfined aquifer, whereas summer precipitation recharges the alluvial aquifer.

\section{Distributed-Parameter Water Balance Model}

The temporal and spatial distributions of potential recharge from MFR and MBR were estimated for the middle San Pedro Watershed using a distributed-parameter waterbalance model (Basin-Characterization Model, BCM; Flint and Flint, 2007). The BCM has been used in other recent studies to estimate the spatial and temporal distribution of 
recharge in alluvial basins in Arizona as part of groundwater budget and groundwater model development (Tillman and others, 2011; Pool and others, 2011; Garner and Truini, 2011). Data inputs to the BCM include precipitation, temperature, and geologic properties to estimate the spatial and temporal distribution of water available to become MFR and MBR.

The BCM calculates the monthly spatial distribution of available water for in-place recharge and potential runoff (in millimeters per month per 270-by-270-meter grid cell) using spatially distributed properties of soils and geologic units and spatial and temporal distributions of climate parameters. In-place recharge is water that infiltrates into the subsurface where precipitation occurs and represents MBR. In the middle San Pedro River Watershed, recharge in the mountains composed of nonaquifer rocks (fig. 14) is minimal, with the exception of the fracture zones described by Hopkins (2014). Recharge can occur in the mountain areas composed of the permeable limestone, where water from precipitation and snow melt can infiltrate, percolate, and flow to the basin-fill aquifer (fig. 24). Potential runoff originates as precipitation that does not infiltrate areas of nonaquifer rock and is assumed to move as surface water in channels in the mountain front and may infiltrate in ephemeral channels before reaching the San Pedro River. Potential runoff that enters the regional aquifer in this manner is considered MFR. Together, the sum of in-place recharge and potential runoff constitutes the potential recharge calculated from the BCM.

In previous applications of the $\mathrm{BCM}, 15$ percent of the potential runoff was assumed to become recharge (Flint and Flint, 2007; Tillman and others 2011), where investigators considered recharge to be equal to the sum of the in-place recharge and 15 percent of the potential runoff. The 15-percent value is similar to the percent of ephemeral

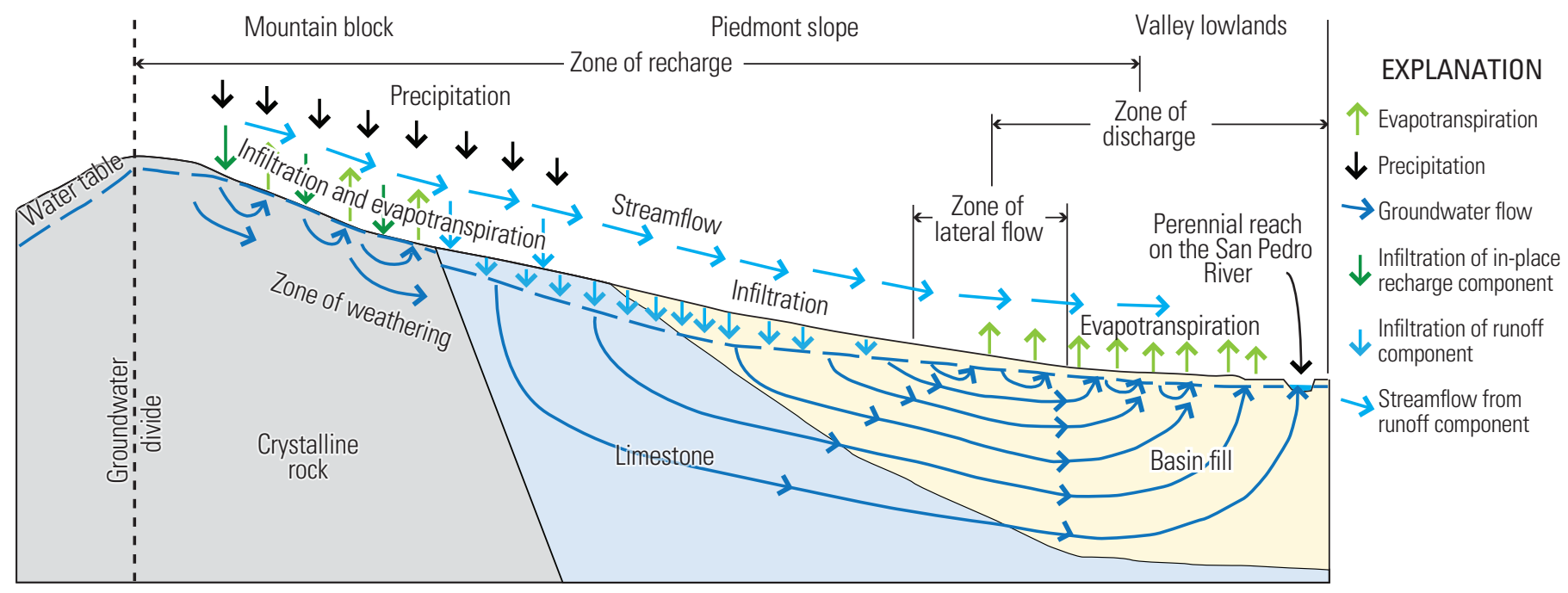

Figure 24. Conceptual illustration of groundwater recharge and discharge in the middle San Pedro Watershed.

Figure 25. Plot showing decadal average annual groundwater recharge calculated from the distributed-parameter water balance model. Groundwater recharge is equal to the sum of the in-place recharge and 15 percent of the potential runoff. The dashed line represents the modified groundwater recharge value in the Benson subarea.

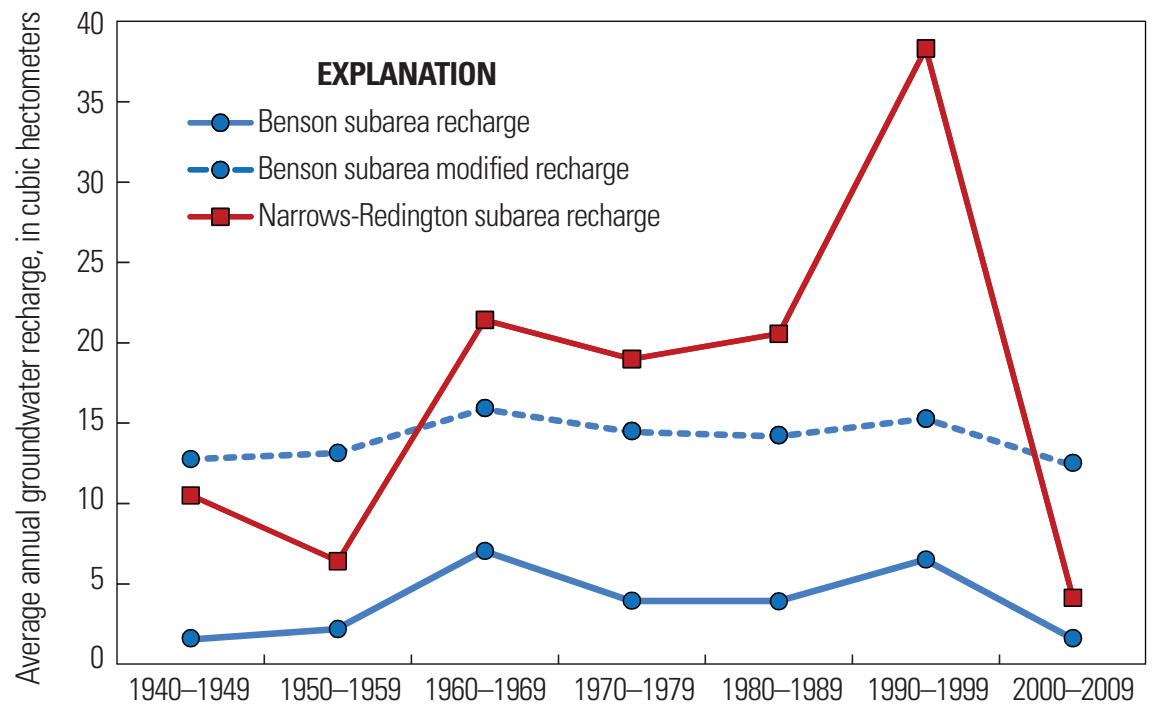


Table 5. Distributed-parameter water-balance model calculated average annual runoff and recharge for 1940-2009 in the middle San Pedro Watershed and subareas. The potential recharge calculated using 100 percent of the potential runoff assumes that all potential runoff infiltrates ephemeral channels and becomes recharge.

[Total recharge equals in-place recharge plus runoff recharge; $\mathrm{hm}^{3}$, cubic hectometer]

\begin{tabular}{|c|c|c|c|c|c|}
\hline \multirow{3}{*}{ Area } & \multicolumn{5}{|c|}{ Wet } \\
\hline & \multicolumn{2}{|c|}{$\begin{array}{l}\text { Percent potential } \\
\text { runoff }\left(\mathrm{hm}^{3}\right)\end{array}$} & \multirow{2}{*}{$\begin{array}{l}\text { In-place } \\
\text { recharge }\end{array}$} & \multicolumn{2}{|c|}{$\begin{array}{c}\text { Percent } \\
\text { potential runoff } \\
\text { recharge }\left(\mathrm{hm}^{3}\right)\end{array}$} \\
\hline & 100 & 15 & & 100 & 15 \\
\hline Benson subarea & 0.56 & 0.08 & 0.94 & 1.50 & 1.02 \\
\hline $\begin{array}{l}\text { Narrows-Redington } \\
\text { subarea }\end{array}$ & 1.63 & 0.24 & 1.47 & 3.10 & 1.71 \\
\hline $\begin{array}{l}\text { Middle San Pedro } \\
\text { Watershed (Total) }\end{array}$ & 2.19 & 0.33 & 2.41 & 4.60 & 2.74 \\
\hline \multirow{3}{*}{ Area } & \multicolumn{5}{|c|}{ Dry } \\
\hline & \multicolumn{2}{|c|}{$\begin{array}{l}\text { Percent potential } \\
\text { runoff }\left(\mathrm{hm}^{3}\right)\end{array}$} & \multirow{2}{*}{$\begin{array}{l}\text { In-place } \\
\text { recharge }\end{array}$} & \multicolumn{2}{|c|}{$\begin{array}{c}\text { Percent } \\
\text { potential runoff } \\
\text { recharge }\left(\mathrm{hm}^{3}\right)\end{array}$} \\
\hline & 100 & 15 & & 100 & 15 \\
\hline Benson subarea & 0.00 & 0.00 & 0.01 & 0.01 & 0.01 \\
\hline $\begin{array}{l}\text { Narrows-Redington } \\
\text { subarea }\end{array}$ & 0.48 & 0.07 & 0.59 & 1.07 & 0.66 \\
\hline $\begin{array}{l}\text { Middle San Pedro } \\
\text { Watershed (Total) }\end{array}$ & 0.48 & 0.07 & 0.61 & 1.09 & 0.68 \\
\hline \multirow{3}{*}{ Area } & \multicolumn{5}{|c|}{ Winter } \\
\hline & \multicolumn{2}{|c|}{$\begin{array}{l}\text { Percent potential } \\
\quad \text { runoff }\left(\mathrm{hm}^{3}\right)\end{array}$} & \multirow{2}{*}{$\begin{array}{l}\text { In-place } \\
\text { recharge }\end{array}$} & \multicolumn{2}{|c|}{$\begin{array}{c}\text { Percent } \\
\text { potential runoff } \\
\text { recharge }\left(\mathrm{hm}^{3}\right)\end{array}$} \\
\hline & 100 & 15 & & 100 & 15 \\
\hline Benson subarea & 1.00 & 0.15 & 1.32 & 2.32 & 1.47 \\
\hline $\begin{array}{l}\text { Narrows-Redington } \\
\text { subarea }\end{array}$ & 6.76 & 1.01 & 6.27 & 13.03 & 7.28 \\
\hline $\begin{array}{l}\text { Middle San Pedro } \\
\text { Watershed (Total) }\end{array}$ & 7.76 & 1.16 & 7.58 & 15.34 & 8.74 \\
\hline \multirow[t]{2}{*}{ Area } & \multicolumn{2}{|c|}{$\begin{array}{c}\text { Percent annual total } \\
\text { recharge }\left(\mathrm{hm}^{3}\right)\end{array}$} & & & \\
\hline & 100 & 15 & & & \\
\hline Benson subarea & 3.83 & 2.50 & & & \\
\hline $\begin{array}{l}\text { Narrows-Redington } \\
\text { subarea }\end{array}$ & 17.20 & 9.65 & & & \\
\hline $\begin{array}{l}\text { Middle San Pedro } \\
\text { Watershed (Total) }\end{array}$ & 21.03 & 12.16 & & & \\
\hline
\end{tabular}

Table 6. Modified average annual natural recharge for the Benson subarea, Narrows-Redington subarea, and the Middle San Pedro Watershed for 1940-2009.

[Runoff recharge equals 15 percent of estimated total runoff. Total recharge equals in-place recharge plus runoff recharge; $\mathrm{hm}^{3}$, cubic hectometer]

\begin{tabular}{lc}
\hline \multicolumn{1}{c}{ Area } & $\begin{array}{c}\text { Annual recharge } \\
\left(\mathbf{h m}^{\mathbf{3}} \mathbf{)}\right.\end{array}$ \\
\hline Benson subarea & 7.08 \\
Narrows-Redington subarea & 9.62 \\
Middle San Pedro Watershed (Total) & 16.7 \\
\hline
\end{tabular}

channel infiltration in the Sierra Vista Subwatershed estimated by Coes and Pool (2007). Their results suggested that ephemeral channel recharge accounts for about 12 to 19 percent of the estimated average annual recharge. For this study, potential recharge is calculated in two ways, on the basis of 15- and 100-percent of potential runoff. The potential recharge calculated using 100 percent potential runoff assumes that all potential runoff infiltrates ephemeral channels and becomes recharge. The potential runoff is not routed through ephemeral channels to the San Pedro River in the BCM.

Spatial and Temporal Distribution of Mountain-Block and Mountain-Front Recharge in the Benson Subarea

In the Benson subarea, most potential recharge occurs in the Whetstone and Dragoon Mountains during the wet months, with lesser recharge in the winter months and least in the dry months. The rates of potential recharge were greatest for 1960-1969 and 1990-1999 (fig. 25). The periods with the lowest available water for potential recharge were 1940-1949 and 2000-2009. The average annual potential recharge for the Benson subarea calculated using 100-percent and 15-percent runoff for 1940-2009, was $3.83 \mathrm{hm}^{3} / \mathrm{yr}$ and $2.50 \mathrm{hm}^{3} / \mathrm{yr}$ respectively (table 5). These potential recharge values are underestimates of potential recharge on the basis of previous recharge estimates for the Benson subarea and in comparison to the other components of the groundwater budget. ADWR (2005) estimated that annual recharge in the Benson subarea was $13.1 \mathrm{hm}^{3} / \mathrm{yr}$. An additional recharge constant of $4.58 \mathrm{hm}^{3} / \mathrm{yr}$ was added to the average annual potential recharge $\left(2.50 \mathrm{hm}^{3} / \mathrm{yr}\right)$ calculated from the distributed-parameter water balance model. This recharge constant was estimated by balancing the groundwater budget without pumping or incidental recharge for 2001-2009. The modified distributed-parameter water-balance model-calculated long-term recharge value was $7.08 \mathrm{hm}^{3} / \mathrm{yr}$, the value used in the Benson subarea groundwater budget (table 6).

Spatial and Temporal Distribution of Mountain-Block and Mountain-Front Recharge in the Narrows-Redington Subarea

In the Narrows-Redington subarea, the rates of potential recharge are greatest in the winter months with lesser recharge in the wet months and the least in the dry months. The rates 
of potential recharge are greatest in the Santa Catalina Mountains. The largest rate of potential recharge over a ten-year period was that during 1990-1999, and the driest decadal period was 2000-2009 (fig. 25). The average annual potential recharge using 100-percent and 15-percent runoff for the time period 1940-2009 was $17.2 \mathrm{hm}^{3} / \mathrm{yr}$ and $9.65 \mathrm{hm}^{3} / \mathrm{yr}$, respectively (table 5). The potential recharge calculated from 15-percent runoff was used in the Narrows-Redington groundwater budget. The higher values of potential recharge in the Narrows-Redington subarea compared to the Benson subarea are consistent with the findings of Pool and others (2011), who found that BCM results are heavily dependent on altitude because of the higher precipitation rates, lower temperatures, and the lower rates of ET at higher altitudes than at lower altitudes. In general, the results of BCM simulations for the middle San Pedro Watershed are consistent with results of Tillman and others (2011) in that recharge rates are much greater in the Narrows-Redington subarea (Lower San Pedro Basin) than in the Benson subarea (Upper San Pedro Basin).

\section{Mountain-Front-Recharge Estimation Using the SWAB RASA Regression Model}

Groundwater recharge from MFR in the middle San Pedro Watershed was also calculated using a regression model developed by Freethey and Anderson (1986). The SWAB RASA Regression model may not be appropriate for the smaller subareas, however, and was therefore applied over the entire middle San Pedro Watershed.

Annual MFR estimates made using the SWAB RASA regression model ranged from $13.62 \mathrm{hm}^{3} / \mathrm{yr}$ to $26.44 \mathrm{hm}^{3} / \mathrm{yr}$ in the middle San Pedro Watershed for the period 1940-2009. Annual recharge estimates from the model for the entire middle San Pedro Watershed averaged $19.57 \mathrm{hm}^{3} / \mathrm{yr}$ for the time period 1940-2009. The estimated MFR on a decadal scale showed an increase during the period 1950-1999 and a decrease from 1980 through 2009 (fig. 26).

\section{Comparison of the Recharge Estimates Between the Distributed-Parameter Water Balance Model and the Regression Model}

Annual recharge estimates from the BCM and SWAB RASA regression model are compared for water years 1940-2009. The BCM values used for the comparison include the sum of the in-place recharge and 15-percent of potential runoff. The average decadal potential recharge estimates from the $\mathrm{BCM}$ ranged from $3.49 \mathrm{hm}^{3} / \mathrm{yr}$, to $23.9 \mathrm{hm}^{3} / \mathrm{yr}$, whereas the average decadal values of the MFR estimated from the SWAB RASA regression model were higher, ranging from $13.6 \mathrm{hm}^{3} / \mathrm{yr}$, to $26.4 \mathrm{hm}^{3} / \mathrm{yr}$. The average annual BCMand SWAB RASA-estimated recharge was $12.2 \mathrm{hm}^{3} / \mathrm{yr}$ and $19.6 \mathrm{hm}^{3} / \mathrm{yr}$, respectively. The BCM decadal values show two distinct decades of higher recharge, in 1960-1969 and in 1990-1999. The SWAB RASA decadal values show an increase in MFR starting in 1950-1959 and extending through 1980-1989. A difference between the BCM and the SWAB RASA regression model is that the SWAB RASA model does not account for the effects of the geology and a basin topography, whereas the $\mathrm{BCM}$ does; this could be reason for the differences in the recharge estimates from the two models.
Figure 26. Plot showing decadal average annual recharge in the middle San Pedro Watershed calculated from the Southwest Alluvial Basins-Regional Aquifer System Analysis (SWABRASA) regression equation and from the distributed-parameter water balance model.

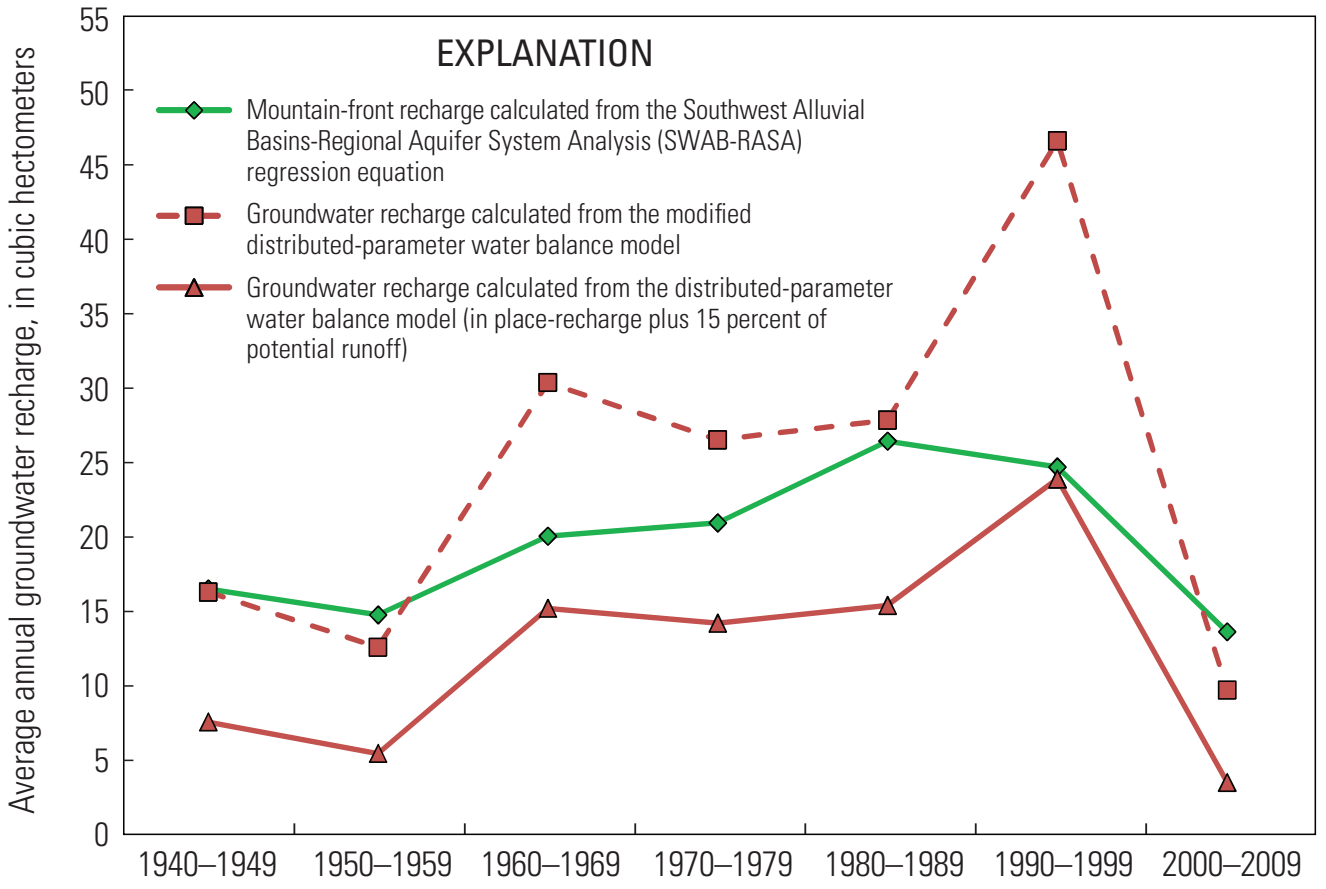


Table 7. Description of methods for estimating monthly seepage in reaches of the San Pedro River, middle San Pedro Watershed, Arizona. [NA, not applicable]

\begin{tabular}{|c|c|c|c|c|c|c|}
\hline \multicolumn{7}{|c|}{ Method for estimating monthly seepage for indicated reach } \\
\hline $\begin{array}{l}\text { Charleston to } \\
\text { Redington }\end{array}$ & SCR & $\begin{array}{l}\text { (1) Regression } \\
\text { equation }\end{array}$ & $\begin{array}{l}\text { Measured loss in } \\
\text { runoff from Charleston } \\
\text { to Redington }\end{array}$ & $\begin{array}{l}\text { Measured runoff at } \\
\text { Charleston }\end{array}$ & CQ & $\mathrm{SCR}=\mathrm{a}(\mathrm{CQ}) \mathrm{b}$ \\
\hline $\begin{array}{l}\text { Charleston to } \\
\text { Tombstone }\end{array}$ & SCT & $\begin{array}{l}\text { (2) Change in } \\
\text { median } \\
\text { low flows }\end{array}$ & NA & $\begin{array}{l}{ }^{2} \text { Median measured low } \\
\text { flow at Charleston }(\mathrm{BC}) \\
\text { and Tombstone }(\mathrm{BT})\end{array}$ & $\mathrm{BC}, \mathrm{BT}$ & $\mathrm{SCT}=\mathrm{BT}-\mathrm{BC}$ \\
\hline $\begin{array}{l}\text { Tombstone to } \\
\text { Benson }\end{array}$ & STB & $\begin{array}{l}\text { (3) Regression } \\
\text { equation }\end{array}$ & $\begin{array}{l}\text { Measured loss in } \\
\text { runoff from Tombstone } \\
\text { to Benson }\end{array}$ & $\begin{array}{l}\text { Estimated streamflow } \\
\text { infiltration from Tombstone } \\
\text { to Redington }\end{array}$ & STR & $\mathrm{STB}=\mathrm{a}(\mathrm{STR}) \mathrm{b}$ \\
\hline $\begin{array}{l}\text { Benson to } \\
\text { Redington }\end{array}$ & SBR & $\begin{array}{l}\text { (5) Difference } \\
\text { in estimated } \\
\text { streamflow } \\
\text { infiltration }\end{array}$ & NA & NA & NA & $\mathrm{SBR}=\mathrm{STR}-\mathrm{STB}$ \\
\hline
\end{tabular}

${ }^{1}$ Regression equations for SCR and STB are explained in table 10.

${ }^{2}$ Median monthly low flows for Charleston and Tombstone were calculated for the concurrent records of 1968-1986 and $1997-2007$.

\section{Groundwater Recharge by Seepage from the San Pedro River}

Groundwater recharge by seepage is streamflow that infiltrates into the stream-channel sediments and then percolates to the water table. In stream reaches where the aquifer water table is higher than the stream-water surface, groundwater discharges to the stream and the stream gains water. In reaches where the water table is below the stream-water surface, the stream loses water and the aquifer is recharged by seepage. The amount and distribution of stream-aquifer exchanges are a function of magnitude and duration of streamflow, stream-channel morphology (width and depth), orientation of stream channel to down-valley subsurface groundwater flow, hydraulic properties of the streambed and underlying floodplain aquifer, transpiration from riparian vegetation, and depth to the water table.

Currently, the water table of the floodplain aquifer is below the channel of the San Pedro River throughout nearly the entire study area for most of the year, thus all stream-aquifer exchange is seepage from the river to the aquifer. Seepage of streamflow in the San Pedro River is from base flow to the river during the winter from Tombstone to near St. David, and from runoff to the river during the entire year, especially from thunderstorm runoff during the summer. The amount of groundwater recharge through seepage from the river channel varies considerably from year to year as a function of the amount of runoff in the main stem of the river and the amount and location of runoff in tributary streams. During times of large and sustained runoff, the river will flow continuously from Tombstone to Redington. At other times, the river will lose water and eventually stop flowing upstream of Redington.

Groundwater seepage from the San Pedro River for the period 1914-2007 (table 1) was estimated from monthly streamflow records at five gages. The methods used to make these estimates are described in table 7. The differences in monthly flows between gages were assumed to be the infiltration of water (seepage) from the river channel to the underlying sediments. The Tombstone-to-Benson reach encompasses the Benson subarea and the Benson-to-Redington reach encompasses the Narrows-Redington subarea. Due to differences in the periods of records of each gage, two regression equations were developed to estimate monthly seepage in two reaches. Seepage was estimated for the concurrent periods of record (1968-2007) at the gaged sites (table 8) to form the basis for the regression equations to estimate seepage in the Tombstone-to-Benson and the Charleston-to-Redington reaches. Separate seepage estimates were calculated for total flow, low flow, and runoff for the concurrent periods of record. 
Table 8. Gains and losses in monthly measured streamflow between gaging stations with concurrent periods of records on the San Pedro River, middle San Pedro Watershed, Arizona.

$\left[\mathrm{m}^{3} / \mathrm{s}\right.$, cubic meters per second]

\begin{tabular}{|c|c|c|c|c|c|c|c|c|c|c|}
\hline \multirow{2}{*}{$\begin{array}{l}\text { Gaging-station pairs } \\
\text { and river reaches }{ }^{1}\end{array}$} & \multirow{2}{*}{$\begin{array}{l}\text { Period of } \\
\text { concurrent } \\
\text { record }\end{array}$} & \multicolumn{9}{|c|}{ Gain (+) or loss (-) in monthly measured streamflow between gaging stations ${ }^{2}$} \\
\hline & & $\begin{array}{l}\text { Number } \\
\text { of flows }\end{array}$ & $\begin{array}{l}\text { Median } \\
\text { change } \\
\left(\mathrm{m}^{3} / \mathrm{s}\right)\end{array}$ & $\begin{array}{l}\text { Percent } \\
\text { of losses }\end{array}$ & $\begin{array}{l}\text { Number } \\
\text { of flows }\end{array}$ & $\begin{array}{c}\text { Median } \\
\text { change } \\
\left(\mathrm{m}^{3} / \mathrm{s}\right)\end{array}$ & $\begin{array}{l}\text { Percent } \\
\text { of losses }\end{array}$ & $\begin{array}{l}\text { Number } \\
\text { of flows }\end{array}$ & $\begin{array}{l}\text { Median } \\
\text { change } \\
\left(\mathrm{m}^{3} / \mathrm{s}\right)\end{array}$ & $\begin{array}{l}\text { Percent } \\
\text { of losses }\end{array}$ \\
\hline Charleston to Tombstone & $\begin{array}{l}1968-1986, \\
1997-2007\end{array}$ & 369 & -0.03 & 57 & 244 & -0.05 & 75 & 125 & 0.19 & 28 \\
\hline Charleston to Redington & 1944-2007 & 739 & -0.24 & 83 & 520 & -0.24 & 93 & 219 & -0.33 & 59 \\
\hline Tombstone to Redington & $\begin{array}{l}1968-1986 \\
1997-2007\end{array}$ & 369 & -0.21 & 83 & 244 & -0.17 & 89 & 125 & -0.44 & 71 \\
\hline Tombstone to Benson & $\begin{array}{l}1967-1976 \\
2006-2007\end{array}$ & 141 & -0.27 & 89 & 103 & -0.26 & 98 & 38 & -0.37 & 66 \\
\hline
\end{tabular}

${ }^{1}$ The gains or losses in measured streamflow for gaging-station pairs including Redington were determined by combining flows from the two gages near Redington (09472000, 1968-1997; 09472050, 1998-2007).

${ }^{2}$ All months of the year were used to calculate statistics for gains and losses in flow between gaging stations.

\section{Groundwater Recharge by Seepage in the Benson Subarea}

Average annual seepage for 1914-2007 in the Benson subarea, calculated by using a regression equation, ranged from $5.36 \mathrm{hm}^{3} / \mathrm{yr}$ to $29.29 \mathrm{hm}^{3} / \mathrm{yr}$ with an average of 13.82 $\mathrm{hm}^{3} / \mathrm{yr}$ (fig. 27). The regression equation is based on 36 pairs of calculated seepage between Tombstone and Benson as the response variable and the calculated seepage between Tombstone and Redington as the explanatory variable (table 9). The regression equation has an $\mathrm{R}^{2}$ of 0.86 and an average standard error of 32 percent (table 10). The longterm annual seepage in the Benson subarea appears to have decreased at a rapid and variable rate during the last 30 years. Average seepage during the wet months for the periods 19141930 and 1997-2009 has decreased by 50 percent. Most of the seepage still occurs during the wet season, with progressively lesser amounts during the winter and dry seasons.

\section{Groundwater Recharge by Seepage in the Narrows-Redington Subarea}

Groundwater recharge by seepage in the NarrowsRedington subarea was estimated by subtracting the seepage from the Tombstone-Benson reach from the seepage from the Tombstone to Redington reach. The seepage from the Tombstone-Benson reach was estimated from a regression equation based on 121 pairs of calculated seepage from the
Tombstone-Redington reach as the explanatory variable and calculated seepage from the Tombstone-Benson reach as the response variable. The seepage from the Tombstone-toRedington reach was estimated by subtracting the calculated seepage from the Charleston-Redington reach from the calculated seepage from the Charleston-Tombstone reach. The regression equation developed to calculate the monthly seepage between Charleston and Redington has an $\mathrm{R}^{2}$ of 0.51 and an average standard error of 52 percent (table 10). A spline ratio was necessary to make a smooth transition between base-flow seepage and the lower regression estimates of seepage. All Charleston flows less than $0.40 \mathrm{~m}^{3} / \mathrm{s}$ were assumed to infiltrate into the aquifer. For streamflow at Charleston greater than $0.85 \mathrm{~m}^{3} / \mathrm{s}$, infiltration was computed using the regression equation. For streamflows at Charleston between $0.40 \mathrm{~m}^{3} / \mathrm{s}$ and $0.85 \mathrm{~m}^{3} / \mathrm{s}$, infiltration was estimated using a spline ratio. Groundwater seepage in the Charleston and Tombstone reach was estimated from the median change in low flows (table 11).

Average annual seepage for 1914-2007 in the NarrowsRedington subarea calculated from the difference between Tombstone-Benson seepage from the estimated TombstoneRedington seepage ranged from $0.00 \mathrm{~m}^{3} / \mathrm{yr}$ to $10.65 \mathrm{~m}^{3} / \mathrm{yr}$ (fig. 27). The average annual seepage for 1914-2007 was $2.84 \mathrm{~m}^{3} / \mathrm{yr}$. In the Narrows-Redington subarea annual seepage appears to have decreased at a slow rate or almost leveled out during the last 30 years. Seepage has declined by about 65 percent for wet, dry, and winter seasons. Most annual seepage still occurs during the wet season, with progressively lesser amounts during the winter and the dry seasons. 

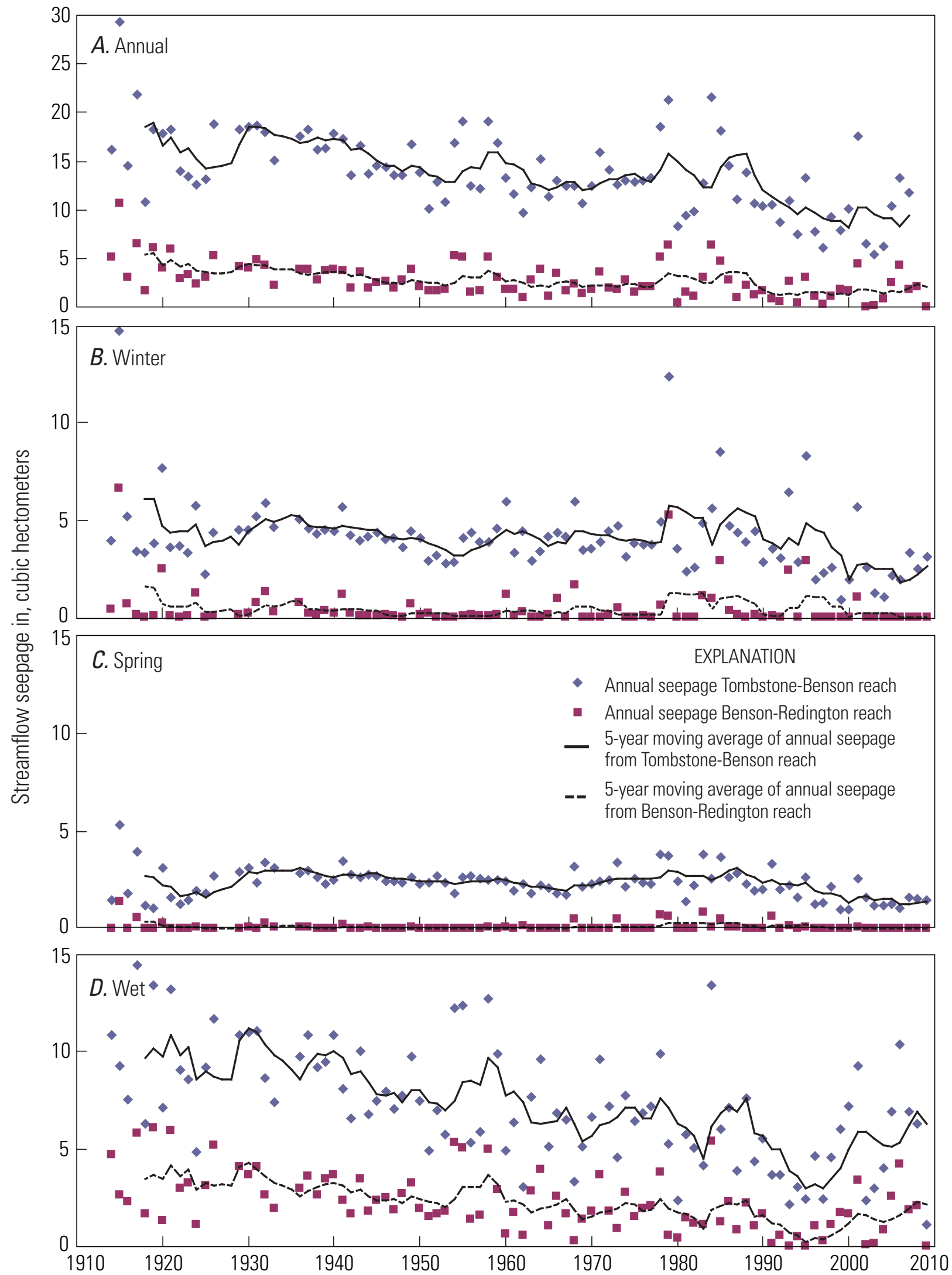

Figure 27. Plots of annual and seasonal streamflow seepage in the Benson and Narrows-Redington subareas of the middle San Pedro River Watershed, Arizona. 
Table 9. Average daily discharge and seepage values used to develop equation for estimating seepage between Tombstone and Benson.

\begin{tabular}{|c|c|c|c|c|c|c|c|c|}
\hline \multirow{2}{*}{ Month } & \multirow{2}{*}{ Year } & \multirow{2}{*}{$\begin{array}{l}\text { Number of daily } \\
\text { values used to } \\
\text { calculate average } \\
\text { discharge and } \\
\text { seepage }\end{array}$} & \multicolumn{3}{|c|}{$\begin{array}{l}\text { Average daily discharge, } \\
\text { in cubic meters per second }\end{array}$} & \multicolumn{3}{|c|}{$\begin{array}{l}\text { Average daily seepage, } \\
\text { in cubic meters per second }\end{array}$} \\
\hline & & & Tombstone & Benson & Redington & $\begin{array}{l}\text { Tombstone- } \\
\text { Redington }\end{array}$ & $\begin{array}{l}\text { Tombstone- } \\
\text { Benson }\end{array}$ & $\begin{array}{l}\text { Benson- } \\
\text { Redington }\end{array}$ \\
\hline July & 1966 & 4 & 8.11 & 6.70 & 4.81 & 3.31 & 1.42 & 1.89 \\
\hline July & 1966 & 2 & 20.27 & 15.98 & 6.33 & 13.95 & 4.29 & 9.66 \\
\hline July & 1967 & 12 & 8.53 & 6.18 & 2.62 & 5.90 & 2.34 & 3.56 \\
\hline August & 1967 & 5 & 2.46 & 1.74 & 0.33 & 2.13 & 0.72 & 1.41 \\
\hline August & 1968 & 2 & 2.35 & 1.13 & 0.08 & 2.27 & 1.22 & 1.05 \\
\hline July & 1969 & 4 & 9.44 & 4.76 & 0.45 & 8.98 & 4.68 & 4.30 \\
\hline July & 1971 & 6 & 20.99 & 10.20 & 5.57 & 15.41 & 10.78 & 4.63 \\
\hline August & 1971 & 3 & 16.97 & 1.71 & 1.35 & 15.62 & 15.26 & 0.36 \\
\hline September & 1971 & 3 & 3.23 & 0.59 & 0.02 & 3.21 & 2.64 & 0.57 \\
\hline September & 1971 & 6 & 5.30 & 0.97 & 0.58 & 4.72 & 4.33 & 0.40 \\
\hline July & 1972 & 4 & 8.73 & 3.23 & 1.67 & 7.06 & 5.50 & 1.56 \\
\hline August & 1972 & 3 & 4.21 & 3.12 & 1.79 & 2.42 & 1.09 & 1.33 \\
\hline September & 1972 & 2 & 4.93 & 2.36 & 1.78 & 3.14 & 2.56 & 0.58 \\
\hline September & 1972 & 4 & 5.48 & 3.10 & 1.47 & 4.01 & 2.38 & 1.63 \\
\hline August & 1975 & 3 & 2.78 & 1.23 & 0.59 & 2.18 & 1.55 & 0.64 \\
\hline September & 1975 & 3 & 22.80 & 17.33 & 15.49 & 7.31 & 5.47 & 1.84 \\
\hline January & 1976 & 4 & 1.30 & 0.00 & 0.00 & 1.30 & 1.30 & 0.00 \\
\hline July & 1976 & 5 & 13.11 & 8.05 & 4.38 & 8.73 & 5.06 & 3.67 \\
\hline August & 1976 & 4 & 5.23 & 1.07 & 0.23 & 5.00 & 4.16 & 0.84 \\
\hline September & 1976 & 3 & 4.68 & 1.43 & 1.04 & 3.64 & 3.25 & 0.40 \\
\hline August & 2006 & 3 & 10.13 & 6.61 & 5.03 & 5.10 & 3.52 & 1.58 \\
\hline September & 2006 & 9 & 6.22 & 2.27 & 0.63 & 5.59 & 3.95 & 1.64 \\
\hline October & 2006 & 3 & 1.26 & 0.52 & 0.04 & 1.22 & 0.75 & 0.48 \\
\hline July & 2007 & 4 & 6.15 & 1.41 & 1.22 & 4.93 & 4.74 & 0.19 \\
\hline August & 2007 & 8 & 11.22 & 8.34 & 4.73 & 6.49 & 2.89 & 3.60 \\
\hline September & 2007 & 5 & 2.96 & 0.74 & 0.18 & 2.78 & 2.23 & 0.55 \\
\hline
\end{tabular}


Table 10. Regression equations for estimating monthly seepage along the San Pedro River from Charleston to Redington and from Tombstone to Benson, middle San Pedro Watershed, Arizona.

[SCR, monthly seepage from Charleston to Redington, in cubic meters per second; CQ, monthly discharge at Charleston, in cubic meters per second; STB, monthly seepage from Tombstone to Benson, in cubic meters per second; STR, monthly seepage from Tombstone to Redington, in cubic meters per second; (STR equals estimated seepage from Charleston to Redington minus seepage from Charleston to Tombstone; see table 2)]

\begin{tabular}{|c|c|c|c|c|c|c|c|c|}
\hline \multirow{3}{*}{ Seepage reach } & \multirow{3}{*}{$\begin{array}{c}\text { Number } \\
\text { of flow } \\
\text { pairs }^{1}\end{array}$} & \multicolumn{7}{|c|}{ Regression equation for estimating monthly seepage, in cubic meters per second } \\
\hline & & \multirow{2}{*}{ Equation } & \multirow{2}{*}{$\begin{array}{l}\text { Intercept } \\
\text { (a) }\end{array}$} & \multirow{2}{*}{$\begin{array}{c}\text { Coefficient } \\
\text { (b) }\end{array}$} & \multirow{2}{*}{ R-squared } & \multicolumn{3}{|c|}{ Standard error } \\
\hline & & & & & & Positive & Negative & Average \\
\hline Charleston to Redington & 121 & $\mathrm{SCR}=\mathrm{a}(\mathrm{CQ}) \mathrm{b}$ & 0.579 & 0.560 & 0.51 & 65 & -39 & 52 \\
\hline Tombstone to Benson & 36 & $\mathrm{STB}=\mathrm{a}(\mathrm{STR}) \mathrm{b}$ & 0.751 & 0.897 & 0.86 & 37 & -27 & 32 \\
\hline
\end{tabular}

${ }^{1}$ Flow pairs are measured monthly flows at Charleston and Redington and at Tombstone and Benson. Seepage values for the regression analysis were estimated by subtracting flows at the two gaging stations in the reach.

Table 11. Monthly changes in seepage along the San Pedro River between Charleston and Tombstone.

\begin{tabular}{lcc}
\hline Month & $\begin{array}{c}\text { Median change in low flow (seepage) } \\
\text { between Charleston and Tombstone, in } \\
\text { cubic meters per second }\end{array}$ \\
\cline { 2 - 3 } & $\mathbf{1 9 1 4 - 1 9 8 6}$ & $\mathbf{1 9 8 7 - 2 0 0 7}$ \\
\hline January & 0.028 & 0.000 \\
February & 0.000 & -0.028 \\
March & 0.000 & 0.000 \\
April & 0.000 & -0.028 \\
May & -0.028 & -0.057 \\
June & -0.057 & -0.057 \\
July & -0.028 & -0.028 \\
August & -0.028 & -0.028 \\
September & -0.028 & -0.028 \\
October & -0.085 & -0.085 \\
November & -0.057 & -0.085 \\
December & -0.028 & -0.057 \\
Annual & -0.026 & -0.040 \\
\hline
\end{tabular}

${ }^{1}$ Positive value is gain and negative value is loss of seepage.

\section{Incidental Recharge from Irrigation}

Another component of the groundwater budget is incidental recharge from irrigation. It is assumed for this study that water applied to a crop in excess of the crop's consumptive use becomes incidental groundwater recharge, and applied water lost to evaporation is negligible. Irrigation efficiency, defined as the percentage of the crop consumptive water requirement divided by the total quantity of water withdrawn for irrigation (Tadayon, 2005), was used to calculate the maximum potential recharge from irrigation water use. The incidental recharge value presented in this section is calculated from the total water applied to the crop, from either groundwater or surface-water sources. This volume of water is not measured directly.
The 2007-2009 incidental recharge values were estimated from data collected in field verification surveys each growing season as described in the upcoming section "Groundwater Withdrawals." The groundwater withdrawals and surface-water diversions were summed by each subarea and then multiplied by an inefficiency coefficient (1 minus the irrigation efficiency). This value represents the maximum quantity of water that is available for recharge from irrigation. An inefficiency coefficient of 0.25 was used in calculations for the period 1985 2009, and a value of 0.30 was used for years prior to 1985 .

As would be expected, the trends in incidental recharge from irrigation follow the trends in total irrigation withdrawals and diversions in each subarea. Volumes of recharge from incidental recharge from irrigation are generally greater in the Benson subarea. Incidental recharge from irrigation in this subarea was greatest in 1973, when total incidental recharge volumes were about $14.0 \mathrm{hm}^{3}$. In 2009 , the incidental recharge from irrigation in the Benson subarea and the NarrowsRedington subarea were $0.90 \mathrm{hm}^{3}$ and $1.36 \mathrm{hm}^{3}$, respectively.

\section{Groundwater Underflow}

The mountains flanking the alluvial basin are composed of nonaquifer rocks that generally restrict groundwater movement from adjacent basins to the east and west of the middle San Pedro Watershed. Groundwater enters the aquifer as underflow through the aquifer from the Sierra Vista Subwatershed and leaves as underflow to the north of Redington into the Lower San Pedro Basin. Groundwater also flows between the subareas through the Narrows; this mostly occurs within the saturated lower basin fill and stream alluvium that is continuous between the two basins. Groundwater underflow cannot be measured directly so alternative methods such as Darcy's Law calculations, groundwater model simulations, or a water-balance approach must be used to estimate this component of the groundwater budget.

The volume of groundwater underflow from the Sierra Vista Subwatershed was estimated on the basis of the findings of previous investigations. The most recent estimate of 
groundwater underflow from the Sierra Vista Subwatershed is from the groundwater flow model created by Pool and Dickinson (2007). Their simulated value of underflow was $1.48 \mathrm{hm}^{3} / \mathrm{yr}$ for the period March 2002 to March 2003. ADWR (2005) calculated $0.54 \mathrm{hm}^{3} / \mathrm{yr}$ of underflow based on model results from Corell and others (1996). Anderson and Freethey (1995) also estimated 0.49 $\mathrm{hm}^{3} / \mathrm{yr}$ based on a groundwater model. The value of $1.48 \mathrm{hm}^{3} /$ yr was used in the Benson subarea groundwater budget to be consistent with the Pool and Dickinson (2007) groundwater model and was assumed to be constant for the entire period 2001-2009. The volume of groundwater underflow out of the Benson subarea to the Narrows-Redington subarea also was estimated on the basis of previous investigations. A geologic map of the area by Drewes (1974) suggests the gap in the bedrock is 200-300 feet wide. Freethey and Anderson (1986) estimate about $0.37 \mathrm{hm}^{3} / \mathrm{yr}$ of groundwater underflow based on the simulation of groundwater flow in the Benson subarea. In the same study, they also simulated the groundwater flow into the entire Lower San Pedro Basin and estimated $2.10 \mathrm{hm}^{3} / \mathrm{yr}$ of groundwater underflow. ADWR (2005) estimated $0.25 \mathrm{hm}^{3} / \mathrm{yr}$ using a flow net analysis based on information from pumping tests near the Narrows. In this report, underflow between the two subareas for the groundwater budget is estimated to be $1.48 \mathrm{hm}^{3} / \mathrm{yr}$ based on the budget described by Anderson and Freethey (1995).

Groundwater underflow out of the watershed was calculated for this investigation on the basis of balancing the groundwater budget for the Narrows-Redington subarea. Previous investigations have developed water budgets for the Lower San Pedro Basin, which extends from the Narrows to the confluence of the Gila and San Pedro Rivers. The groundwater underflow out of the Narrows-Redington subarea was calculated on the basis of the groundwater budget developed for 2001-2009.

A preliminary groundwater budget for the NarrowsRedington subarea was developed without consideration of the groundwater withdrawals for irrigation and incidental recharge. This approach is based on the assumption that the inflows to the aquifer would approximate the outflows from the aquifer in the absence of groundwater withdrawals and incidental recharge. A single groundwater underflow term was then added to the groundwater budget to make the average groundwater budget residual equal to zero. Groundwater outflow from the NarrowsRedington subarea was calculated to be $4.54 \mathrm{hm}^{3} / \mathrm{yr}$ on the basis of balancing the groundwater budget. This value is based on the groundwater budget in the Narrows-Redington subarea for water years 2001-2009.

\section{Groundwater Discharge}

Discharge out of the middle San Pedro Watershed aquifer system occurs through groundwater withdrawals from wells for municipal, domestic, and industrial, and irrigation uses and from riparian ET along the San Pedro River. Groundwater also discharges as underflow near the northern boundary of the watershed as described in the previous section.

\section{Groundwater Withdrawals}

The demand for groundwater in the middle San Pedro Watershed includes withdrawals for municipal, domestic, industrial, and irrigation use in the Benson subarea and domestic and agricultural use in the Narrows-Redington subarea. Groundwater withdrawals in the middle San Pedro Watershed have been dominated by withdrawals for irrigation of fields along the San Pedro River. Groundwater withdrawals increased for all uses around 1940 with the widespread adoption of high-powered pumps (Pool and Dickinson, 2007).

\section{Groundwater Withdrawal Data}

Annual groundwater withdrawals were estimated from 1940 to 2009 on the basis of historical data from previous studies. Municipal withdrawals for the City of Benson for 1940, 1950, 1960, and 1970 were estimated on the basis of data from the U.S. Census. After 1980, municipal groundwater withdrawals were estimated from records of metered annual deliveries from 13 municipal water providers in the Benson subarea. Annual groundwater withdrawals for industrial use were obtained from annual metered reports of groundwater withdrawals beginning in 1966. Withdrawals for irrigation were based on irrigated acreages for 1936, 1941, 1953, 1966, 1969, and 1970, which were estimated from Roeske and Werrell (1973). The irrigated acreages for 1956, 1971, and 1978 were estimated from aerial photographs downloaded from the U.S. Geological Survey Seamless Data Warehouse (http://seamless. usgs.gov/, accessed September 10, 2010). The irrigated acreage for 1965 was estimated from the Cropland Atlas of Arizona by Mayes (1974). The irrigated acreages between 1985-2005 were estimated at 5-year intervals from data downloaded from the U.S. Geological Survey National Water-Use Program website (http://water.usgs.gov/watuse/, accessed September 15, 2010). The 2006 irrigated acreage was estimated from Google Earth Imagery. Irrigated acreages for 2007 through 2009 were estimated from field surveys in both the Benson and the Narrows-Redington subareas. The acreage irrigated from surface-water diversions from the San Pedro River were obtained from the ADWR (1994). The self-supplied domestic population from 1940 through 2000 was estimated from the U.S. Census data and from intercensal estimates by the Arizona Department of Administration Office of Employment and Population Statistics (2011) for 2001-2009.

\section{Irrigation}

Historically, surface water diverted from the San Pedro River was the primary source of water for irrigation in the middle San Pedro Watershed. Flow in the San Pedro River, however, did not always occur at convenient times or arrive in convenient quantities. For example, diversions and canals were often destroyed by high streamflow events and frequently this runoff water contained high sediment loads that filled canals and 
ditches (ADWR, 1994). Diversions from the San Pedro River for irrigation purposes worked best during low-flow or base-flow conditions. Thus, since the 1940s, groundwater has been the preferred source of irrigation water in the middle San Pedro Watershed.

Groundwater withdrawals and (or) surface-water diversions for irrigation are based on the estimated total irrigated acreage in the middle San Pedro Watershed. These estimates of irrigated acreage in the watershed were then multiplied by the consumptive water requirement of the particular crop. The consumptive water requirements for crops are based on, but not limited to, monthly precipitation and temperature, crop type, and crop harvest and plant dates. The consumptive water requirements for crops were calculated for 2007-2009 from field surveys of irrigated acreage in the middle San Pedro Watershed. The consumptive water requirement for the crop was calculated using the modified Blaney-Criddle method as described by the Bureau of Reclamation (1992, appendix A) and the irrigation efficiency was based on the type of irrigation system. Fields irrigated with a surface drip system were assigned an efficiency between 80 and 90 percent whereas flood irrigated fields were assigned an efficiency ranging from less than 50 percent to 75 percent (Saeid Tadayon, U.S. Geological Survey, oral commun., 2009).

The consumptive crop water requirements for the irrigated fields in the watershed for years 2007, 2008, and 2009 were $1.30 \mathrm{~m}, 1.25 \mathrm{~m}$, and $1.32 \mathrm{~m}$, respectively. For years 1985-2006, detailed information about irrigation systems in the middle San Pedro area was limited, and the average consumptive water requirement for the years 2007-2009 was used. For all years prior to 1985, a consumptive water requirement of $1.37 \mathrm{~m}$ was used, which assumes all crops were flood irrigated either by pumping from wells or diverting water from the San Pedro River.

Groundwater withdrawals for irrigation exceeded all other withdrawals for 1940-2009. Trends in annual groundwater withdrawals for irrigation in the Benson and the Narrows-Redington subareas are similar. In 2009, the withdrawals in the Benson and Narrows-Redington subareas were $2.59 \mathrm{hm}^{3}$ and $3.70 \mathrm{hm}^{3}$, respectively. Withdrawals for irrigation in the Benson subarea increased from $13.6 \mathrm{hm}^{3}$ in 1936 to $25.3 \mathrm{hm}^{3}$ in 1966 (fig. 28) and peaked at $27.8 \mathrm{hm}^{3}$ in 1973. Groundwater withdrawals for irrigation in the Benson subarea have decreased from $11.8 \mathrm{hm}^{3}$ in 1985 to $3.7 \mathrm{hm}^{3}$ in 2009 (fig. 28). Groundwater withdrawals for irrigation in the Narrows-Redington subarea increased from $4.56 \mathrm{hm}^{3}$ in 1936 to $13.9 \mathrm{hm}^{3}$ in 1966 (fig. 29) and peaked at $15.4 \mathrm{hm}^{3}$ in 1973 and also decreased from 1985 to 2009.

\section{Municipal and Industrial}

The City of Benson is the largest municipal provider of water in the study area. Groundwater withdrawals by the city for the years 1940, 1950, 1960, and 1970 were estimated on the basis of U.S. Census data along with a per capita water use of 570 liters per person per day ( 150 gallons per capita per day, gpcd). This per capita water use value was estimated from the average per capita water use values from the City of Benson for years 2006-2008, which were obtained from the Community Water Systems 2008 Annual Water Use Reporting Summary (http://www.azwater.gov/azdwr/StatewidePlanning/ Drought/documents/LSP.pdf, accessed August 16, 2010).

The estimated groundwater withdrawals for municipal use (estimated from the U.S. Census population) in the Benson subarea increased from about $0.20 \mathrm{hm}^{3}$ in 1940 to $0.74 \mathrm{hm}^{3}$ in 1970 (fig. 28). After 1980, the withdrawals were estimated from records of metered annual deliveries from 13 municipal water providers and increased from $0.74 \mathrm{hm}^{3}$ in 1980 to about $2.1 \mathrm{hm}^{3}$ for the period 1998-2009

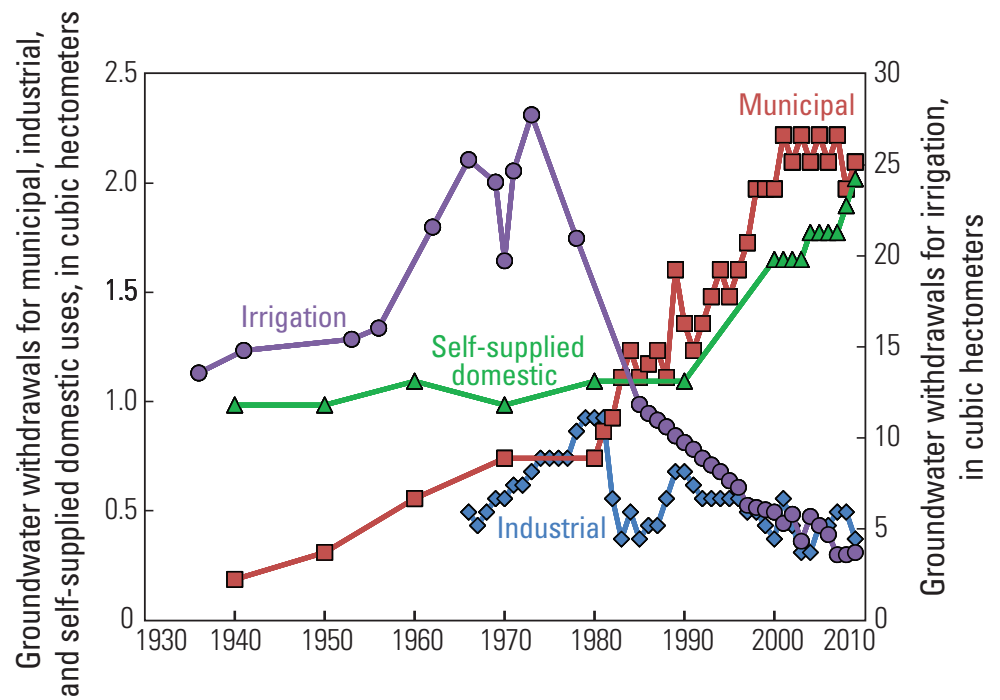

Figure 28. Plot showing annual groundwater withdrawals for irrigation, municipal, self-supplied domestic, and industrial uses in the Benson subarea for 1936-2009.

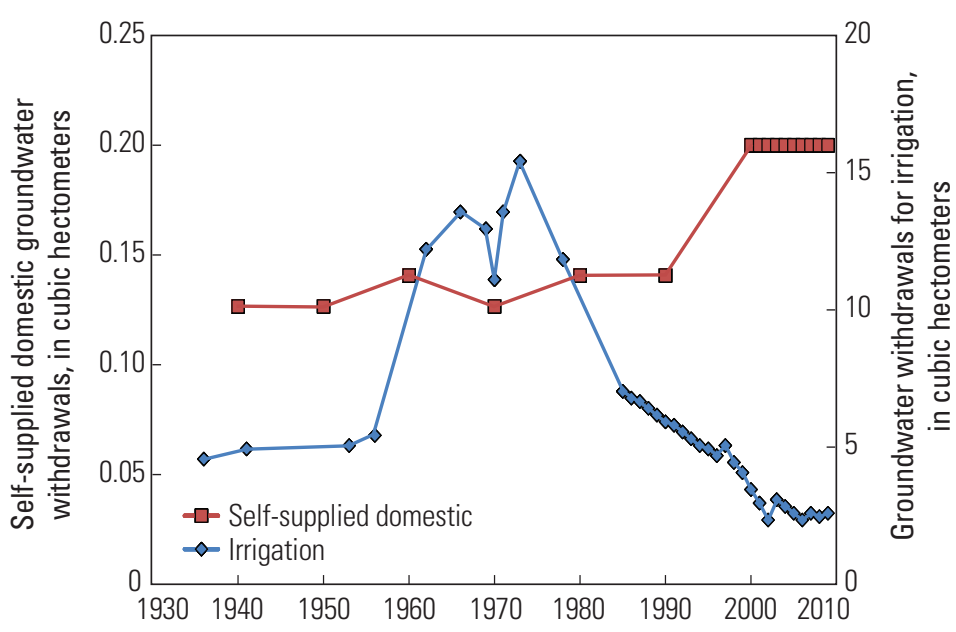

Figure 29. Plot showing annual groundwater withdrawals for irrigation and self-supplied domestic uses in the Narrows-Redington subarea for 1936-2009. 
(fig. 28). Industrial groundwater withdrawals increased from about $0.50 \mathrm{hm}^{3}$ in 1966 to a peak of about $0.90 \mathrm{hm}^{3}$ in 1980, decreased to about $0.40 \mathrm{hm}^{3}$ in 1985 , and then increased again to about $0.70 \mathrm{hm}^{3}$ in 1990 (fig. 28). In 2009, the industrial groundwater withdrawals were $0.40 \mathrm{hm}^{3}$ (fig. 28).

\section{Self-Supplied Domestic Groundwater Withdrawals}

Households in the middle San Pedro Watershed that do not receive water from municipal or private water suppliers are considered self-supplied domestic users. These households use water from domestic wells and are most likely outside of the service area of municipal water suppliers. Domestic selfsupplied groundwater withdrawals in the middle San Pedro Watershed can be divided into "inside" and "outside" uses of water. The inside portion of domestic self-supplied groundwater withdrawals includes water for household uses such as drinking, food preparation, washing of clothes and dishes, bathing, and flushing of toilets. The outside portion of the withdrawals is used for watering of lawns and (or) small pastures and (or) small gardens, or for evaporative cooling and the watering of small numbers of livestock.

Estimates of self-supplied domestic groundwater withdrawals have been based on the product of the estimated per capita water use and the self-supplied domestic population (Blasch and others, 2006; Tadayon, 2005). The self-supplied domestic population was estimated by calculating the difference between the entire population of the middle San Pedro Watershed and the population served by municipal water suppliers and then multiplying this figure by a per capita water use value. Previous estimates of the per capita water use in the Upper San Pedro Basin range from 570 liters per day per person (150 gpcd) estimated by the ADWR (1994) to 1900 liters per day per person (500 gallons gpcd) by the ADWR (2005). Both of these per capita water use values account for inside and outside water use.

The inside and outside components of self-supplied domestic groundwater withdrawals in the middle San Pedro Watershed were estimated separately using U.S. Census population data. The inside and outside component are both estimated from the self-supplied domestic populations. The inside component was estimated using the self-supplied domestic population in the middle San Pedro area while the outside component was estimated using the approximate number of households with domestic wells. The U.S. Census data for years 1940, 1950, 1960, 1970, 1980, 1990, and 2000 were used to estimate the domestic self-supplied population and households with domestic wells. The intercensal estimates by the Arizona Department of Administration Office of Employment and Population Statistics (2011) were used to estimate the domestic self-supplied population for years 2001 through 2009. The number of households with domestic wells was calculated by dividing the self-supplied domestic population by the average number of persons per household in Cochise County as obtained from U.S. Census data.

Detailed monthly metered withdrawals from domestic wells over the one-year period from 2009-2010 were used to separate the inside and outside per capita water use values (Barbara Clark, The Nature Conservancy, written commun., 2010). From these records, the per capita water use for the month of March was identified as the per capita water use representative of inside use. During this month, it was assumed that there was no watering of the grass or garden and no evaporative cooler use. The outside use was calculated by subtracting the annual cumulative volume of inside domestic water use from the total volume of the domestic groundwater withdrawals; the remaining volume of water is considered outside domestic use. The self-supplied domestic population in the Narrows-Redington subarea was estimated from the number of households identified from 2010 aerial photos.

Domestic self-supplied groundwater withdrawals were generally larger in the Benson subarea than in the NarrowsRedington subarea. Domestic self-supplied groundwater withdrawals in the Benson subarea ranged from $0.98 \mathrm{hm}^{3} / \mathrm{yr}$ to $2.09 \mathrm{hm}^{3} / \mathrm{yr}$ (fig. 28). Domestic self-supplied groundwater withdrawals in the Benson subarea increased by the greatest amount between 1990 and 2000. The average annual self-supplied domestic groundwater withdrawals for 2001-2009 in the Benson subarea was $1.93 \mathrm{hm}^{3} / \mathrm{yr}$. In the Narrows-Redington subarea, domestic self-supplied groundwater withdrawals ranged from $0.13 \mathrm{hm}^{3} / \mathrm{yr}$ to $0.20 \mathrm{hm}^{3} / \mathrm{yr}$ (fig. 29). The average annual selfsupplied domestic groundwater withdrawals for 2001-2009 in the Narrows-Redington subarea was $0.20 \mathrm{hm}^{3} / \mathrm{yr}$.

\section{Evapotranspiration of Groundwater in Riparian Areas}

Groundwater is removed by evapotranspiration (ET) from the saturated and unsaturated alluvium in riparian areas along the San Pedro River. The ET from groundwater and surface water has two components: direct evaporation of water from wet soil or canopies following a rain event, and plant transpiration. In the arid and semi-arid southwestern United States, surface soils are normally dry. Hence, evaporation from the soil is a relatively minor component of total ET in arid and semiarid regions.

The rates of ET have been studied extensively in the Upper San Pedro Basin since the early 2000s. The first detailed estimates of ET by riparian vegetation in the Upper San Pedro Basin were made using remote sensing data and field measurements (Goodrich and others, 2000). These estimates of riparian groundwater withdrawals were later updated by Scott and others (2006) using an eddy-covariance technique for various riparian vegetation types. Nagler and others (2005a) combined in-place measurements with remote sensing to estimate riparian ET in the Upper San Pedro Basin for years 2000-2004. Scott and others (2008) used ET rates from eddy covariance methods to develop an empirical relationship between ET and remote sensing data and land surface temperature to scale up ET rates in the Upper San Pedro Basin.

In this study, ET is calculated by vegetation index (VI) methods to obtain basin-wide temporal and spatially distributed ET rates. VI is useful for calculating ET from phreatophyte communities in arid and semiarid regions 
Table 12. Average estimated annual rates of evapotranspiration (ET) and the groundwater component of evapotranspiration $\left(\mathrm{ET}_{\mathrm{gw}}\right.$ ) for 2001-2009.

[mm/yr, millimeters per year; $\mathrm{hm}^{3} / \mathrm{yr}$, cubic hectometers per year]

\begin{tabular}{|c|c|c|c|c|c|}
\hline \multirow{2}{*}{$\begin{array}{l}\text { Vegetation } \\
\text { groupings }\end{array}$} & \multirow{2}{*}{$\begin{array}{l}\text { Area, in } \\
\text { hectares }\end{array}$} & \multicolumn{2}{|c|}{ ET } & \multicolumn{2}{|c|}{$\mathrm{ET}_{\mathrm{gw}}$} \\
\hline & & $\mathrm{mm} / \mathrm{yr}$ & $\mathrm{hm}^{3} / \mathrm{yr}$ & $\mathrm{mm} / \mathrm{yr}$ & $\mathrm{hm}^{3} / \mathrm{yr}$ \\
\hline Sparse grass and shrubs & 836 & 333 & 2.78 & 142 & 1.19 \\
\hline Mesquite woodlands & 1769 & 612 & 10.8 & 379 & 6.71 \\
\hline Cottonwood-willow & 1494 & 856 & 12.8 & 609 & 9.1 \\
\hline Sparse grass and shrubs & 588 & 401 & 2.36 & 199 & 1.17 \\
\hline Mesquite woodlands & 963 & 670 & 6.46 & 435 & 4.20 \\
\hline Cottonwood-willow & 981 & 952 & 9.34 & 700 & 6.86 \\
\hline
\end{tabular}

because ET is dominated by the plant transpiration component (Scott and others, 2008). The VI models used to estimate ET (reviewed in Glenn and others, 2007; Kalma and others, 2008) are based on the observation that foliage density on the ground, as measured by satellite, is often strongly correlated with ET (Glenn and others, 2010), but VI methods must be combined with meteorological data to calculate atmospheric water demand and the energy available to evaporate water. Furthermore, the algorithms used to calculate ET in VI models need to be regressed against ground measurements of ET in the biome of interest to develop empirical relationships between ET, meteorological data, and VIs (Glenn and others, 2010). Thus, the accuracy of the VI model for ET is constrained by the accuracy of the ground measurements of ET by which they are calibrated and by the degree of correlation between foliage density and ET.

The spatial distribution of riparian vegetation along the San Pedro River within the middle San Pedro Watershed were identified from the Arizona Gap Analysis Project map (hereinafter referred to as AzGap; Halverson and others, 2001; Bennett and others, 2004). The AzGap map shows the distribution of vegetation types that were classified from satellite imagery and field verification. The vegetation groupings within areas defined by the AzGap map were divided into three different groupings on the basis of the mean Enhanced Vegetative Index (EVI) data of the single month of June for 2000 through 2009. These vegetation groupings are sparse grass and shrubs, mesquite woodlands, and cottonwood-willow (table 12). Irrigated fields along the San Pedro River were excluded from the analysis because they are irrigated with pumped groundwater.

\section{ET Models Based on Vegetative Index}

Several VI methods for estimating ET have been developed for phreatophyte communities. Groeneveld and others (2007) used the Normalized Difference Vegetation Index (NDVI) approach and single, summer Landsat images to estimate ET for a wide variety of phreatophyte communities in the western United States. The VI approach was modified for the present study by using the Enhanced Vegetative Index (EVI) products (Huete and others, 2002) from the Moderate Resolution Imaging Spectrometer (MODIS) sensors on the Terra satellite (obtained from http://daac.ornl.gov/MODIS/ modis.shtml), instead of the NDVI products from Landsat imagery. MODIS products commonly are used in phenological and change-detection studies, which require stable vegetation index values over time (Glenn and others, 2010). MODIS EVI products consistently give better predictions of ET than MODIS NDVI products (Glenn and others, 2010) which support their use in this study. EVI was scaled between bare soil and maximum vegetation for this study using values for EVImin and EVImax from a previous study (Nagler and others, 2005b). The scaled value of EVI is referred to as EVI*. Potential ET was calculated by the Blaney-Criddle (BC) method (Blaney and Criddle,1964).

The ET model for the middle San Pedro Watershed was evaluated by comparison of ET rates for agricultural crops calculated by the ET model to ET rates calculated by crop coefficient methods, which were obtained from The Arizona Meteorological Network (AZMET) (http://ag.arizona.edu/azmet/, accessed December 13, 2010). Despite a reasonable fit of predicted ET to measured ET values for riparian vegetation $\left(\mathrm{R}^{2}=0.91\right)$ using a linear relation between EVI* and ET, ET is overestimated for center-pivot-irrigated grain and corn crops in the nearby Wilcox Basin to the east. An exponential rise-to-a-max exponential function between EVI* and ET, however, resulted in a reasonable fit for mixed areas of agricultural fields and riparian vegetation (Nagler and others, 2005b).

Rainfall averaged $244 \mathrm{~mm} /$ year over the period 2000-2009. The groundwater component of ET ( $\left.\mathrm{ET}_{\mathrm{gw}}\right)$ is estimated by subtracting in-place precipitation (from PRISM, 2010) from the total ET (Scott and others, 2008), assuming that the remaining amount of water is derived from groundwater and runoff from precipitation is negligible. Most of the San Pedro River in the study area is ephemeral, and some surface water becomes available to phreatophytes only during short-term flow events. Surface water, however, is a source of water to phreatophytes in intermittent reaches.

Temperature and precipitation data are required for ET calculations. For the EVI* ET calibration equations, the mean daily air temperature $\left(\mathrm{T}_{\text {mean }}\right)$ was measured at the individual covariance flux tower sites used by Scott and others (2008). For projecting over the entire length of the river, three sources of $\mathrm{T}_{\text {mean }}$ were available: from spatially and temporally distributed maximum and minimum daily temperature values $\left(\mathrm{T}_{\max }\right.$ and $\mathrm{T}_{\text {min }}$, respectively) from PRISM (http://www.prism.oregonstate. 


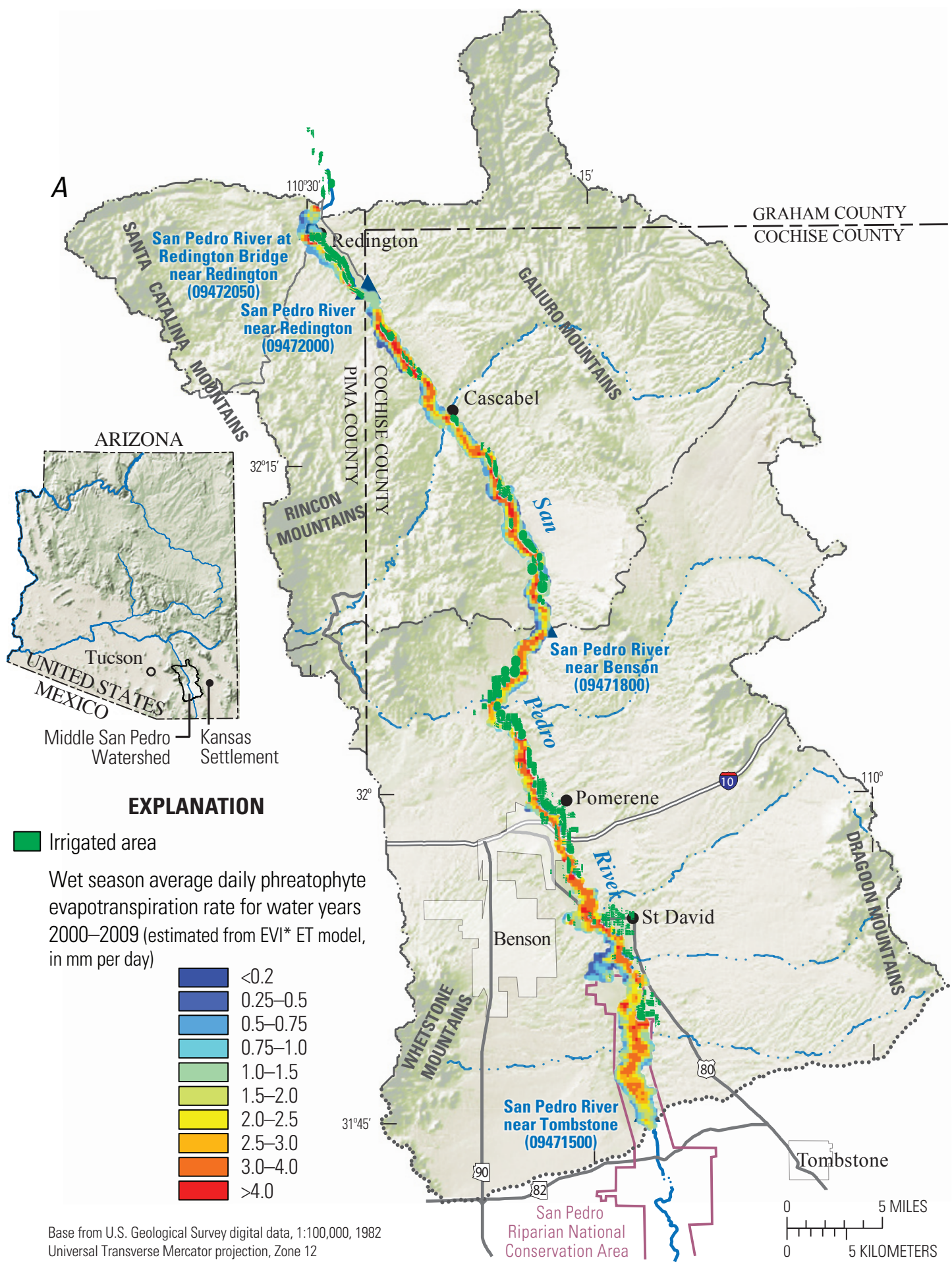

Figure 30. Maps showing seasonal distribution of the groundwater component of evapotranspiration $\left(\mathrm{ET}_{\mathrm{gw}}\right)$ in the middle San Pedro Watershed for $(A)$ wet, $(B)$ dry, and $(C)$ winter seasons (continued on next two pages). 


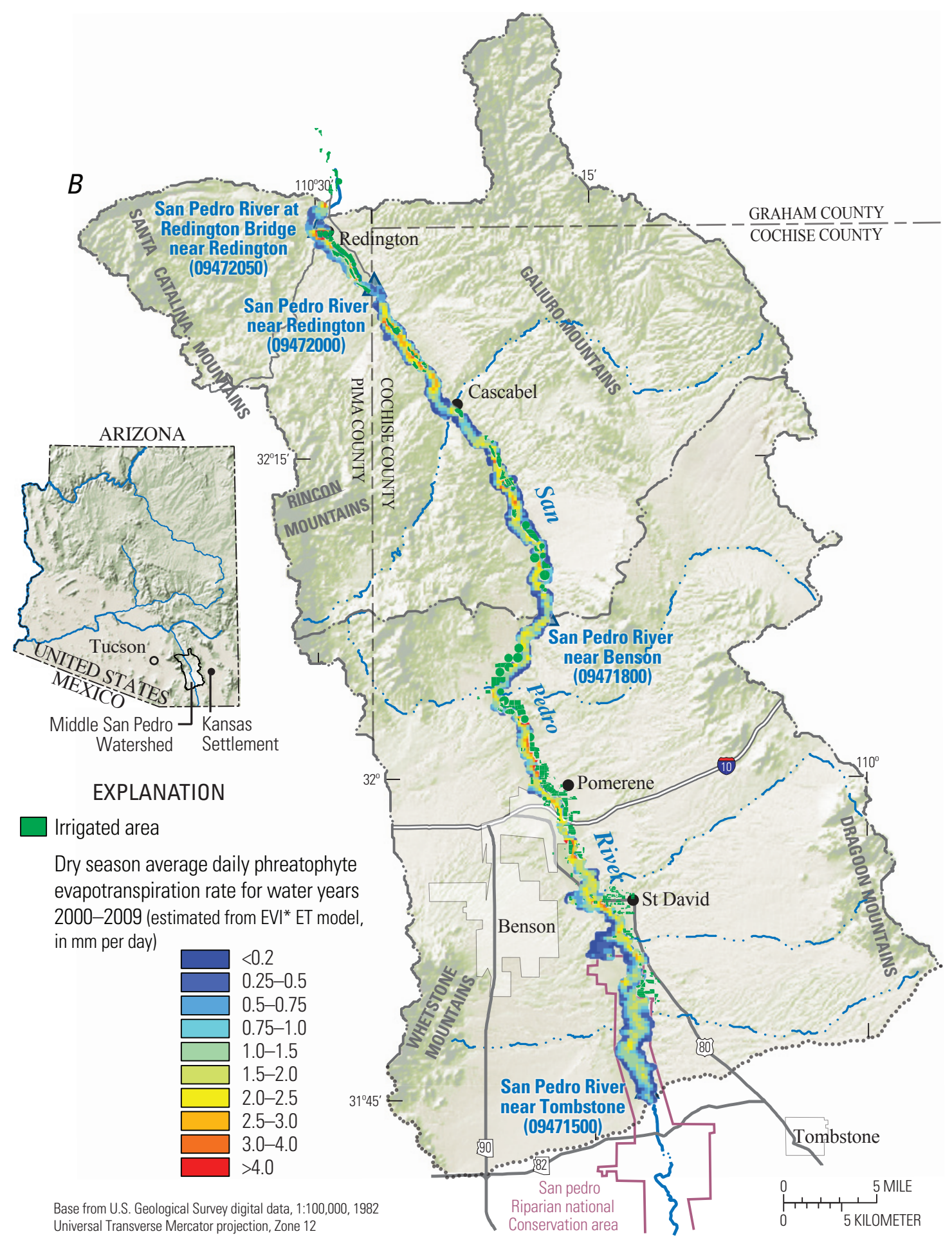

Figure 30. Maps showing seasonal distribution of the groundwater component of evapotranspiration $\left(\mathrm{ET}_{\mathrm{gw}}\right)$ in the middle San Pedro Watershed for $(A)$ wet, $(B)$ dry, and $(C)$ winter seasons.-Continued 


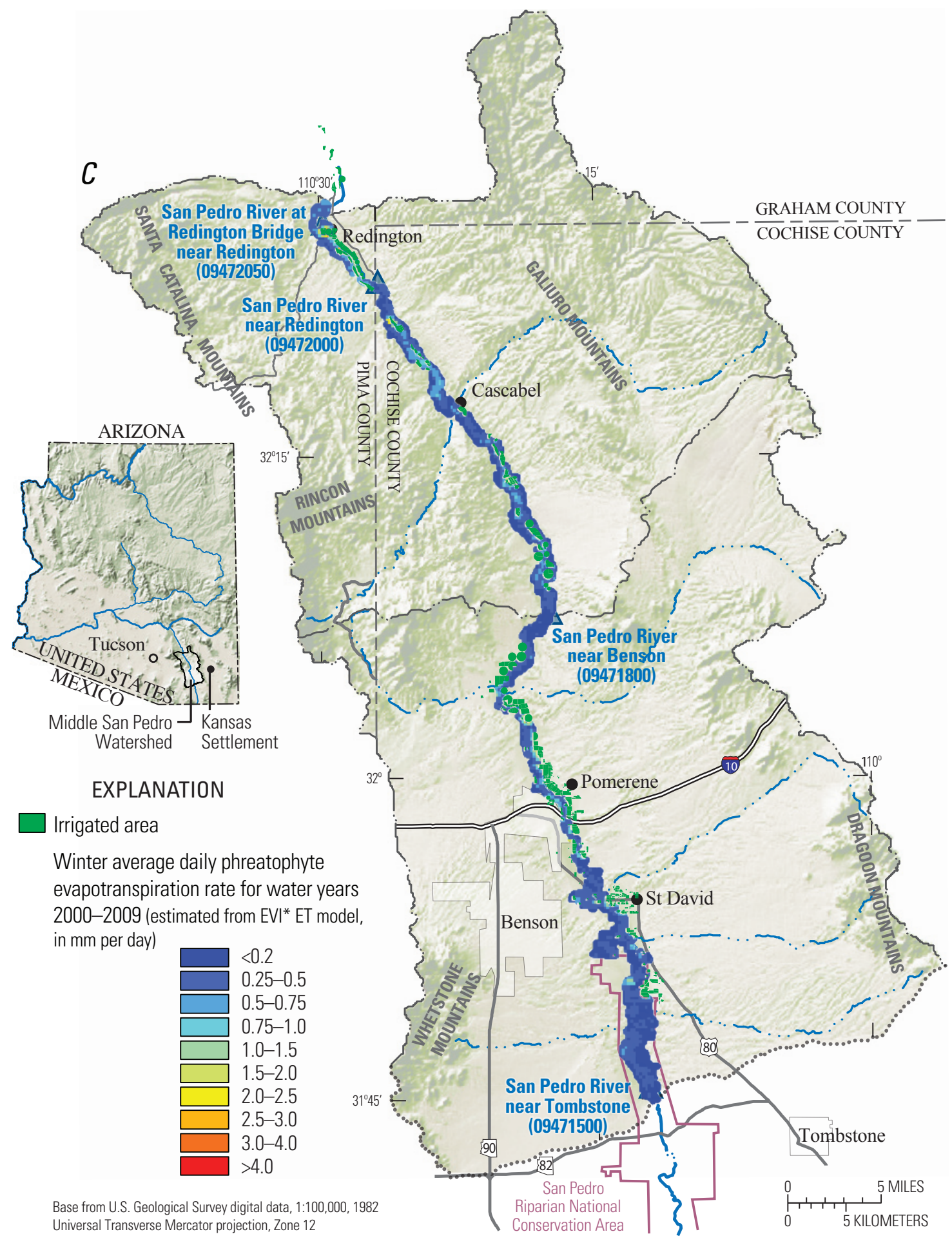

Figure 30. Maps showing seasonal distribution of the groundwater component of evapotranspiration $\left(\mathrm{ET}_{\mathrm{gw}}\right)$ in the middle San Pedro Watershed for $(A)$ wet, $(B) \mathrm{dry}$, and $(C)$ winter seasons. - Continued 


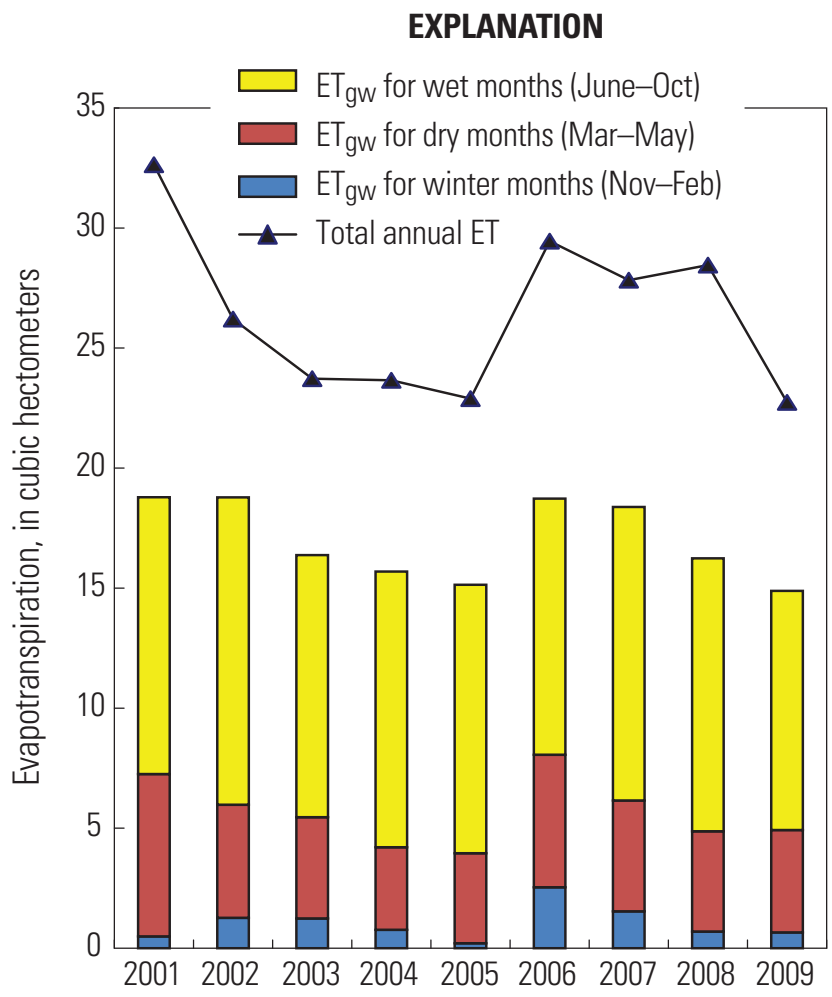

Figure 31. Plot showing seasonal evapotranspiration (ET) and groundwater component of evapotranspiration $\left(\mathrm{ET}_{\mathrm{gw}}\right)$ in the Benson subarea for the years 2001-2009.

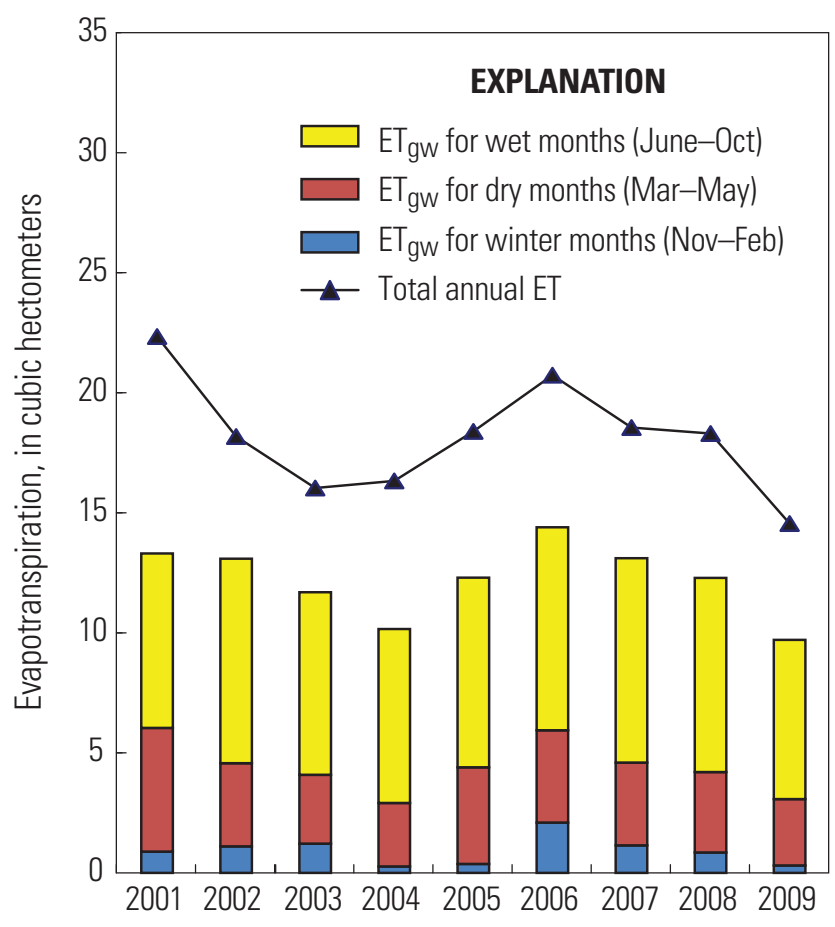

Figure 32. Plot showing seasonal evapotranspiration (ET) and groundwater component of evapotranspiration $\left(\mathrm{ET}_{\mathrm{gw}}\right)$ in the Narrows-Redington subarea for years 2001-2009.

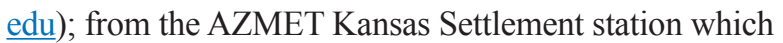
has a climate similar to the middle San Pedro area; and from MODIS nighttime land surface temperature (LST) satellite imagery. While all three sources of $\mathrm{T}_{\text {mean }}$ data could be used interchangeably, $\mathrm{T}_{\text {mean }}$ was obtained from the PRISM website because of the availability of the data for the time period 2000-2009 and full spatial distribution. Gridded precipitation data were also obtained from the PRISM Website.

\section{Application of the EVI* ET Model}

Annual $\mathrm{ET}_{\mathrm{gw}}$ values for water years 2001-2009 were calculated for both subareas and included in the respective groundwater budgets (fig. 30). The EVI* ET model is applied for riparian areas along the San Pedro River to obtain temporally and spatially distributed $\mathrm{ET}_{\mathrm{gw}}$ values from 2000 2009. $\mathrm{ET}_{\mathrm{gw}}$ is calculated for the total riparian area defined by the AzGap map that coincides with the riparian area and the floodplain along the San Pedro River. The application methods are based on those used by Nagler and others $(2005 a, b)$ for riparian areas along the Colorado River and by Tillman and others (2011) for riparian and agricultural areas in basins in southern Arizona. The MODIS data processing and EVI* calculation was done using Esri's ArcGIS software.

Average annual ET ${ }_{\mathrm{gw}}$ and ET for 2001-2009 in the Benson subarea ranged from $14.9 \mathrm{hm}^{3} / \mathrm{yr}$ to $18.8 \mathrm{hm}^{3} / \mathrm{yr}$ and $22.9 \mathrm{hm}^{3} / \mathrm{yr}$ to $32.6 \mathrm{hm}^{3} / \mathrm{yr}$ respectively (fig. 31 ). The annual $\mathrm{ET}_{\mathrm{gw}}$ varied about 13 percent of the annual average. This result suggests there is little annual variation in $\mathrm{ET}_{\mathrm{gw}}$ regardless of the annual precipitation. Annual $\mathrm{ET}_{\mathrm{gw}}$ has decreased from 18.7 $\mathrm{hm}^{3}$ in 2006 to $14.9 \mathrm{hm}^{3}$ in 2009 , which is the lowest annual value for 2001-2009. Within a year, the rates of $\mathrm{ET}_{\mathrm{gw}}$ are the greatest during the wet periods (summer monsoon season) followed by the dry periods (spring and fall) and least during the winter. The average annual rates of $\mathrm{ET}_{\mathrm{gw}}$ by vegetation grouping in descending order are cottonwood-willow, mesquite woodlands, and sparse grass and shrubs (table 12).

Average annual $\mathrm{ET}_{\mathrm{gw}}$ and ET for 2001-2009 in the Narrows-Redington subarea ranged from $10.2 \mathrm{hm}^{3} / \mathrm{yr}$ to $14.4 \mathrm{hm}^{3} / \mathrm{yr}$ and $14.6 \mathrm{hm}^{3} / \mathrm{yr}$ to $22.3 \mathrm{hm}^{3} / \mathrm{yr}$ respectively (fig. 32). The annual $\mathrm{ET}_{\mathrm{gw}}$ varied about 21 percent of the annual average. Compared to the Benson subarea, there is more annual variation in $\mathrm{ET}_{\mathrm{gw}}$ in the Narrows-Redington subarea. Annual $\mathrm{ET}_{\mathrm{gw}}$ has decreased from $14.4 \mathrm{hm}^{3}$ in 2006 to $9.7 \mathrm{hm}^{3}$ in 2009 , which is the lowest annual value for 2001-2009. The average annual rates of $\mathrm{ET}_{\mathrm{gw}}$ by vegetation grouping in descending order are cottonwood-willow, mesquite woodlands, and sparse grass and shrubs (table 12).

Sources of error in the fitted coefficients in the ET model are the measurements of ET at the eddy covariance flux towers. Eddy covariance flux tower data are subject to an energy closure error of 10-30 percent when ET results are used in a surface-energy-balance equation (Scott, 2010). ET values are usually increased in magnitude to force energy closure, and that procedure was used for the data used in this study (Scott, 2010). The cause of the energy closure and what 
Table 13. Groundwater budget for the Benson subarea for water years 2001-2009.

$\left[\mathrm{hm}^{3} / \mathrm{yr}\right.$, cubic hectometers per year]

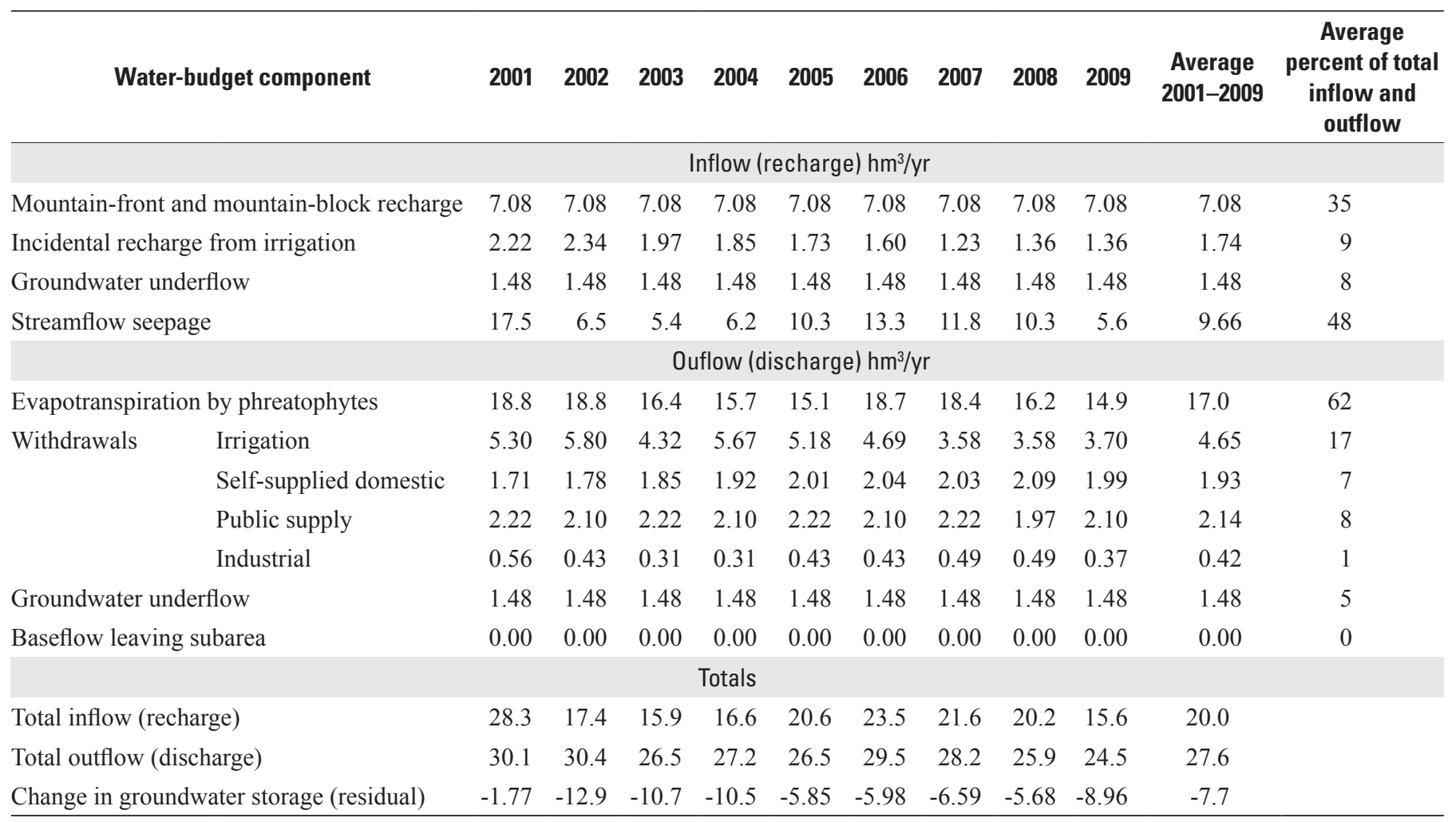

to do about it is unclear (Scott, 2010); in the present case, ET values corrected for energy closure were 22 percent higher than uncorrected values, and represents a source of error or uncertainty in the present ET estimates.

\section{Changes in Groundwater Storage}

Under natural conditions, inflows may not equal outflows during short-term climate variations; however over longer periods under natural conditions, total inflow to and total outflow from an aquifer are approximately equal and net changes in groundwater storage are minimal. Following development of groundwater resources, inflows to the aquifer may not equal the outflows because of changes in land use and (or) changes in groundwater withdrawals. The source of groundwater withdrawn for pumping is increased recharge, decreased discharge such as reduction in base flow to the San Pedro River, reduction in $\mathrm{ET}_{\mathrm{gw}}$, or removal from groundwater storage, or a combination of the three. A decrease in groundwater storage contributes to groundwaterlevel declines. That is, groundwater levels decline if the rates of discharge exceed the rates of recharge to the aquifer.

The annual groundwater-storage component or water-budget balance for the Benson subarea was negative for water years 2001 to 2009; outflows in the Benson subarea exceeded inflows. The groundwater storage component ranged in value from $-1.77 \mathrm{hm}^{3}$ in 2001 to $-12.9 \mathrm{hm}^{3}$ in 2002 . The average annual change in groundwater storage was $-7.70 \mathrm{hm}^{3} / \mathrm{yr}$.
The annual groundwater storage component for the Narrows-Redington subarea was negative for water years 2001 to 2009. The change in groundwater storage ranged from $-0.51 \mathrm{hm}^{3}$ in 2001 to $-4.34 \mathrm{hm}^{3}$ in 2002 . The average annual change in groundwater storage was $-2.00 \mathrm{hm}^{3} / \mathrm{yr}$.

\section{Benson Subarea Groundwater Budget}

The average annual inflow to the Benson subarea ranged from $28.3 \mathrm{hm}^{3}$ in 2001 to $15.6 \mathrm{hm}^{3}$ in 2009 and the average for water years 2001-2009 was $20.0 \mathrm{hm}^{3} / \mathrm{yr}$ (table 13). Groundwater recharge from mountain-front and mountain-block and streamflow seepage account for 35 percent and 48 percent, respectively, of the total recharge for water years 2001 to 2009. The longterm natural recharge and groundwater underflow terms were assumed to be constant in the groundwater budget. Variations in total annual recharge are from fluctuations of streamflow infiltration from the San Pedro River and changes in incidental recharge from irrigation. The annual incidental recharge ranged from $1.23 \mathrm{hm}^{3}$ in 2007 to $2.34 \mathrm{hm}^{3}$ in 2002 (table 13). The average annual incidental recharge for 2001 to 2009 was $1.74 \mathrm{hm}^{3} / \mathrm{yr}$ (table 13) and represents 9-percent of all recharge components.

The average annual outflow for water years 2001-2009 from the Benson subarea aquifer system ranged from $24.5 \mathrm{hm}^{3}$ in 2009 to $30.4 \mathrm{hm}^{3}$ for 2002 (table 13) and the average annual discharge was $27.6 \mathrm{hm}^{3} / \mathrm{yr}$ (table 13). Natural discharge from $\mathrm{ET}_{\mathrm{gw}}$ comprises 62 percent of the total discharge for water years 
Table 14. Groundwater budget for the Narrows-Redington subarea for water years 2001-2009.

[Abbreviation: $\mathrm{hm}^{3} / \mathrm{yr}$, cubic hectometers per year]

\begin{tabular}{|c|c|c|c|c|c|c|c|c|c|c|c|}
\hline Groundwater-budget component & 2001 & 2002 & 2003 & 2004 & 2005 & 2006 & 2007 & 2008 & 2009 & $\begin{array}{c}\text { Average } \\
2001-2009\end{array}$ & $\begin{array}{l}\text { Average percent } \\
\text { of total inflow } \\
\text { and outflow }\end{array}$ \\
\hline \multicolumn{12}{|c|}{ Inflow (recharge) hm³/yr } \\
\hline $\begin{array}{l}\text { Mountain-front and mountain-block } \\
\text { recharge }\end{array}$ & 9.62 & 9.62 & 9.62 & 9.62 & 9.62 & 9.62 & 9.62 & 9.62 & 9.62 & 9.62 & 70 \\
\hline Incidental recharge from irrigation & 0.93 & 0.80 & 0.99 & 0.93 & 0.86 & 0.80 & 0.86 & 0.80 & 0.86 & 0.87 & 6 \\
\hline Streamflow seepage & 4.47 & 0.06 & 0.16 & 0.80 & 2.56 & 4.22 & 1.86 & 2.06 & 0.00 & 1.8 & 13 \\
\hline \multicolumn{12}{|c|}{ Outflow (discharge) hm³/yr } \\
\hline Evapotranspiration by phreatophytes & 13.3 & 13.1 & 11.7 & 10.2 & 12.3 & 14.4 & 13.1 & 12.3 & 9.7 & 12.2 & 78 \\
\hline Withdrawals Irrigation & 2.84 & 2.34 & 3.08 & 2.84 & 2.59 & 2.34 & 2.59 & 2.47 & 2.59 & 2.63 & 17 \\
\hline \multicolumn{12}{|c|}{ Totals } \\
\hline Total inflow (recharge) & 16.5 & 12.0 & 12.2 & 12.8 & 14.5 & 16.1 & 13.8 & 14.0 & 12.0 & 13.8 & \\
\hline Total outflow (discharge) & 17.0 & 16.3 & 15.6 & 13.9 & 15.8 & 17.6 & 16.6 & 15.6 & 13.2 & 15.7 & \\
\hline $\begin{array}{l}\text { Change in groundwater storage } \\
\text { (residual) }\end{array}$ & -0.52 & -4.34 & -3.39 & -1.04 & -1.24 & -1.49 & -2.75 & -1.66 & -1.21 & -2.0 & \\
\hline
\end{tabular}

2001 to 2009. Groundwater withdrawals for irrigation comprise 17 percent of the total discharge for water years 2001 to 2009. The average groundwater withdrawals for irrigation, self-supplied domestic, public supply, and industrial combined account for about 33 percent of groundwater withdrawals for water years 2001-2009. Irrigation alone accounted for 17 percent of all groundwater withdrawals for water years 2001-2009.

The change in groundwater storage in the Benson subarea reflects the relation between the inflows and the outflows to the aquifer system. For all years of the groundwater budget, the outflows exceed the inflows and the average change in groundwater storage was $-7.70 \mathrm{hm}^{3} / \mathrm{yr}$ (table 13). The estimated change in groundwater storage showed the greatest decline from years 2001 to 2002 and increased (became less negative) in 2005.

\section{Narrows-Redington Subarea Groundwater Budget}

The average annual inflow to the Narrows-Redington subarea ranged from $16.5 \mathrm{hm}^{3}$ in 2001 to $12.0 \mathrm{hm}^{3}$ in water years 2002 and 2009 (table 14) and the average annual natural inflow for 2001-2009 is $13.8 \mathrm{hm}^{3} / \mathrm{yr}$. Mountain-front and mountainblock recharge and streamflow seepage account for 70 percent and 13 percent, respectively, of the total annual recharge for water years 2001 to 2009. Variations in the natural recharge are from recharge from streamflow infiltration from the San Pedro River. Incidental recharge from irrigation comprises about 6 percent of the total recharge for water years 2001 to 2009.
The average annual outflow for water years 2001-2009 from the Narrows-Redington subarea aquifer system ranged from $13.2 \mathrm{hm}^{3}$ in 2009 to $17.6 \mathrm{hm}^{3}$ in 2006 (table 14) and the average annual natural outflow for water years 2001-2009 was $15.7 \mathrm{hm}^{3} / \mathrm{yr}$. The groundwater withdrawals for irrigation do not show much variation and range from $2.34 \mathrm{hm}^{3} / \mathrm{yr}$ to $3.08 \mathrm{hm}^{3} / \mathrm{yr}$ (table 14). The average annual groundwater withdrawals for irrigation for water years 2001 to 2009 was $2.63 \mathrm{hm}^{3} / \mathrm{yr}$ and represents 17 percent of the total withdrawals. Discharge from $\mathrm{ET}_{\mathrm{gw}}$ is 78 percent and groundwater underflow is 4 percent of the total outflow for water years 2001 to 2009 .

The change in groundwater storage in the Narrows-Redington subarea reflects the relation between the inflows and the outflows to the aquifer system. For all years of the groundwater budget the outflows exceed the inflows and the average change in groundwater storage was $-2.00 \mathrm{hm}^{3} / \mathrm{yr}$ (table 14). From 2001 to 2002 , the change in storage became more negative and from 2002 to 2004 the change in storage became less negative. From 2004 to 2007 the change in storage became more negative and the change in groundwater storage has been less negative since 2007.

\section{Hydrochemistry and Water Quality}

The water chemistry of the middle San Pedro Watershed was investigated to better define groundwater flow paths and to identify sources of recharge to the aquifer systems (Hopkins and others, 2014). Groundwater and surface-water samples were analyzed for water temperature, $\mathrm{pH}$, specific conductance, anions, 


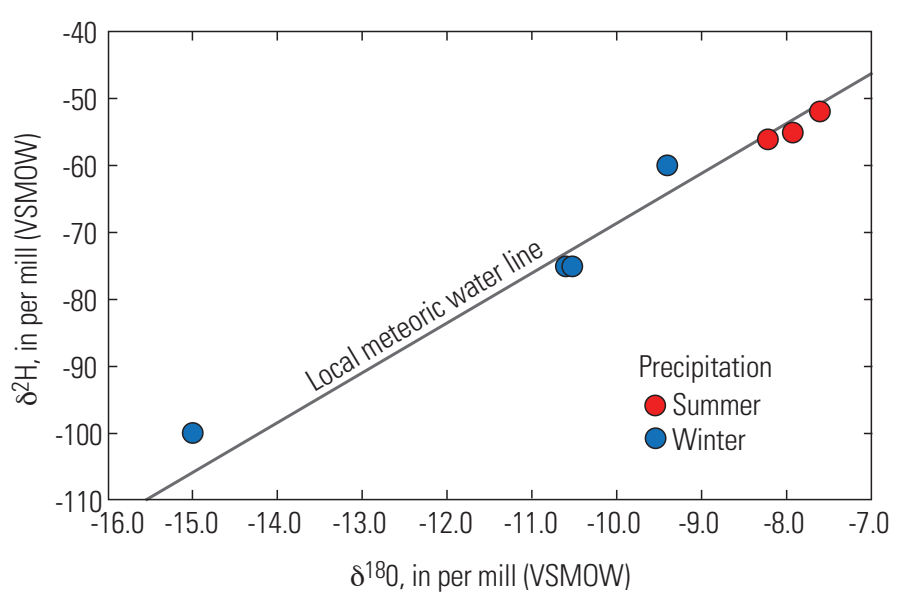

Figure 33. Plot showing oxygen $\left(\delta^{18} 0\right)$ and hydrogen $\left(\delta^{2} \mathrm{H}\right)$ isotope composition in samples of precipitation in the middle San Pedro Watershed plotted in relation to the local meteoric water line (LMWL; Baillie, 2005). Isotopic compositions are calculated in per mil relative to Vienna Standard Mean Ocean Water (VSMOW).

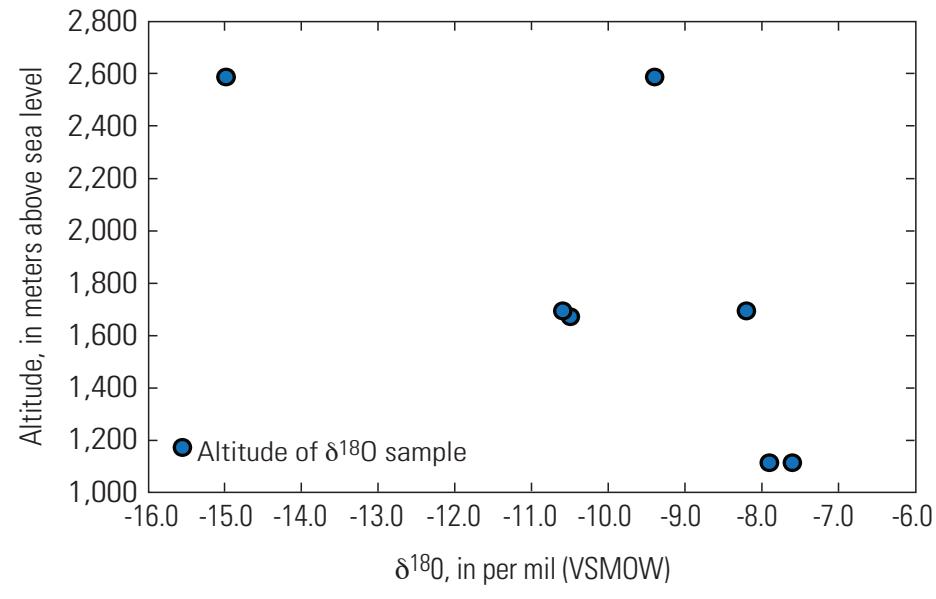

Figure 34. Plot showing $\delta^{18} 0$ compositions for precipitation relative to altitude of sample collection. Isotopic compositions are calculated in per mil relative to Vienna Standard Mean Ocean Water (VSMOW).

cations, and a suite of stable isotopes including carbon, sulfur, oxygen, and hydrogen. Precipitation samples were collected from various elevations in the watershed and were analyzed for oxygen and hydrogen isotopes. Surface-water samples were collected multiple times to identify any seasonal trends in the chemical composition of the surface water. Samples were collected and analyzed following standard USGS protocols from the USGS National Field Manual for the Collection of Water Quality Data (U.S. Geological Survey, variously dated); samples for which exceptions to these protocols were made are noted in appendix A.

\section{Isotopic Composition of Precipitation}

Seven precipitation samples were collected during the years 2008 and 2009. These samples were collected during summer and winter precipitation events. Five-gallon precipitation buckets were left out for the duration of the storm season and water was sampled at the end of seasonal rainfall events. The top of the bucket was covered by a screen to prevent human or animal interference with the sample and a layer of mineral oil was added to the bottom of the bucket to ensure that collected rainwater would not evaporate. The elevation of bucket locations ranged from the San Pedro Basin floor $(1,109 \mathrm{~m})$ to varied steps along the surrounding mountain ranges $(1,665,1,688$, and $2,583 \mathrm{~m}$ ) to account for influences of elevation on the isotopic composition of precipitation.

Oxygen and hydrogen isotopes of precipitation were plotted on the Local Meteoric Water Line (LMWL), developed from Baillie (2005; fig. 33). These samples show variation in isotopic values due to both altitude and seasonal effects. In order to differentiate between seasonal and altitude effects, $\delta^{18} \mathrm{O}$ values were plotted against altitude (fig. 34) to help discern seasonal trends. These seasonal trends show that winter precipitation is the main contributor of the more depleted $\delta^{18} \mathrm{O}$ values of precipitation. The difference between winter and summer samples is smallest ( 0.3 per mil) at $1,109 \mathrm{~m}$ and increases with elevation and has a seasonal difference of 5.6 per mil at 2,583 m (fig. 34).

\section{Surface Water Samples}

Seventeen surface-water samples were collected from the San Pedro River from seven separate collection sites at different times of the year. Oxygen and hydrogen isotopic composition of river samples are within the range of summer precipitation values for upper San Pedro River samples while middle San Pedro River samples are similar or more depleted than the summer precipitation values (fig. 35). Winter precipitation isotopic values are at least 1 per mil depleted compared with the San Pedro River samples. Based on isotopic composition, summer precipitation seems to be a vital component of recharge to the San Pedro River (fig. 35). Surface-water samples had relatively low sulfate-to-chloride ratios (2.76 to 8.73), similar to river-sample values in the upper San Pedro Watershed (fig. 36; Baillie, 2005). Generally, river water was $\mathrm{Ca}-\mathrm{HCO}_{3}$ (calciumbicarbonate) type water (fig. 37).

Six surface-water samples were collected along the San Pedro River from Charleston through Cascabel following a monsoon storm-flow event in August 2008. Oxygen and hydrogen isotope ratios became increasingly enriched with distance downstream (fig. 38). Progressive enrichment trends are parallel to the local meteoric water line, except for the R5 sample (fig. 38), which plots farther to the right of the LMWL, indicating that evaporation has occurred. The overall trend indicates input from a more enriched source, which is often related to lowerelevation precipitation. All river samples collected during the storm were more enriched in oxygen and hydrogen isotope 
composition than the precipitation samples for that season. The precipitation samples shown on figure 38 were a composite of all storms for the summer season of 2008, however, and do not provide a signature for particular isolated storms.

\section{Groundwater and Spring Water Samples}

Seventy-eight groundwater samples were collected from municipal supply wells, private domestic wells, and springs. Two out of six springs that were visited for sampling were flowing: Mackenzie Spring and 4R Spring.

\section{Spatial Variability of Groundwater Chemistry}

Wells were classified into aquifer systems based upon their location and the hydrogeologic unit into which they were drilled, and water zones were identified based on their unique chemical signatures (fig. 39). Driller's logs and screened depth intervals provided information about the geology of each well. Bedrock aquifer systems are identified by wells screened in bedrocklimestone, sandstone, or granite; basin-fill systems have wells located in the unconfined basin fill, above the confining unit; confined basin fill systems have wells located in the lower basin fill, underneath confining unit; and alluvium aquifer systems have wells located in the shallow alluvial aquifer along the river. Dickinson and others (2010a) describe the aquifer units in detail.

Major ion proportions (primarily differences in bicarbonate and calcium) in the groundwater varied widely across sampling sites (fig. 37). Fluoride concentration also varied spatially and was useful in discriminating between different water zones.

In addition to information gained through solute chemistry, solute ratios (calcium/strontium and sulfate/chloride) were utilized to better constrain groundwater geochemical reactions
Figure 35. Plots showing $\delta^{18} \mathrm{O}$ and $\delta^{2} \mathrm{H}$ values from surface-water samples plotted on the local meteoric water line (LMWL; Baillie, 2005). Isotopic compositions are calculated in per mil $(\% \circ)$ relative to Vienna Standard Mean Ocean Water (VSMOW).
Figure 36. Plots showing fluoride and sulfate in groundwater and surface water samples in the middle San Pedro Watershed relative to the U.S. Environmental Protection Agency's drinkingwater standards Primary Maximum Contaminant Level and Secondary Maximum Contaminant Level. Isotopic composition of sulfur are calculated in per mil relative to the Canyon Diablo Troilite (CDT).
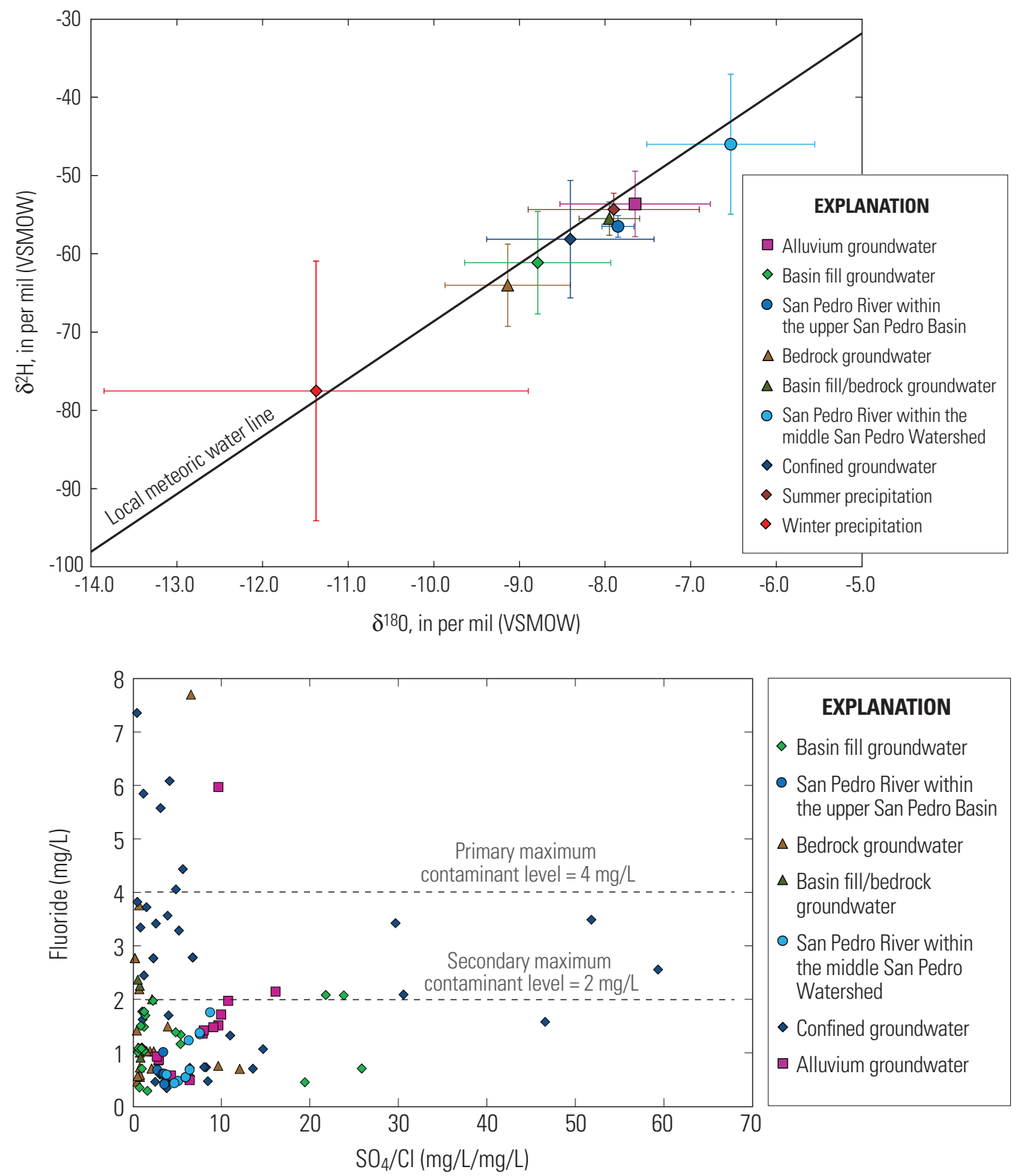
along flowpaths and between aquifer systems. The calcium/strontium ratio offers information regarding residence time of groundwater and the amount of interaction between geologic sources and groundwater, whereas the sulfate/chloride ratio provides information pertaining to the presence and type of evaporites, while excluding the effects of evaporation. Smaller values of calcium/strontium ratios generally indicate longer groundwater residence time: as waters become supersaturated in calcite with increased water-rock interaction, the mineral calcite $\left(\mathrm{CaCO}_{3}\right)$ may precipitate while strontium remains in solution. Sulfate/chloride ratios are highly variable in this system and are controlled by several processes such as reducing (decrease in oxidation state) groundwater environments, which would decrease the sulfate/chloride ratio, or a change in the input of sulfate to the system over time from anthropogenic activities such as mining (Baillie, 2005).

Radiogenic isotopes, such as radioactive ${ }^{14} \mathrm{C}$ (half-life 5,730 years) and tritium $\left({ }^{3} \mathrm{H}\right.$, half-life 12.32 years) are useful for determining relative groundwater residence times over short ( $<50$ years) to long (up to $\sim 30,000$ to 50,000 years) timescales (Clark and Fritz, 1997). Tritium values were plotted versus $\delta^{18} \mathrm{O}$ to understand how recharge elevation and season is related to presence of modern water. Generally, samples with $\delta^{18} \mathrm{O}$ more depleted than -10 per mil (high elevation winter precipitation) were associated with tritium values less than $1 \mathrm{TU}$, and for more enriched samples tritium values ranged between $<0.6$ and $6.9 \mathrm{TU}$ (fig. 40). Carbon-14 has also been utilized to estimate average recharge rates to regional aquifer systems to verify numerical flow models (Zhu, 2000).

The bedrock aquifer receives modern recharge, as indicated by a majority of samples containing detectable amounts of tritium; only 3 of 14 samples analyzed for tritium are below the detection limit (fig. 40). Seven wells analyzed for ${ }^{14} \mathrm{C}$ have moderate values with an average of 48.8 percent modern carbon (pmc), and high calcium/strontium average value of 167 (fig. 41). Oxygen and hydrogen isotopes from the bedrock aquifer have the most negative average isotopic signatures -64 per mil $\delta^{2} \mathrm{H}$ and -9.1 per mil $\delta^{18} \mathrm{O}$ (fig. 35) and indicate that recharge to the bedrock aquifer is a mix of both summer and winter precipitation. Low sulfate/chloride average ratio (2.7) and low average fluoride concentrations $(1.54 \mathrm{mg} / \mathrm{L})$ indicate that waters in the fracture system have had very little time to interact with the surrounding rock matrix (fig. 36). Sulfur isotopes $\left(\delta^{34} \mathrm{~S}\right.$ average 8.3 per mil, relative to the Canyon

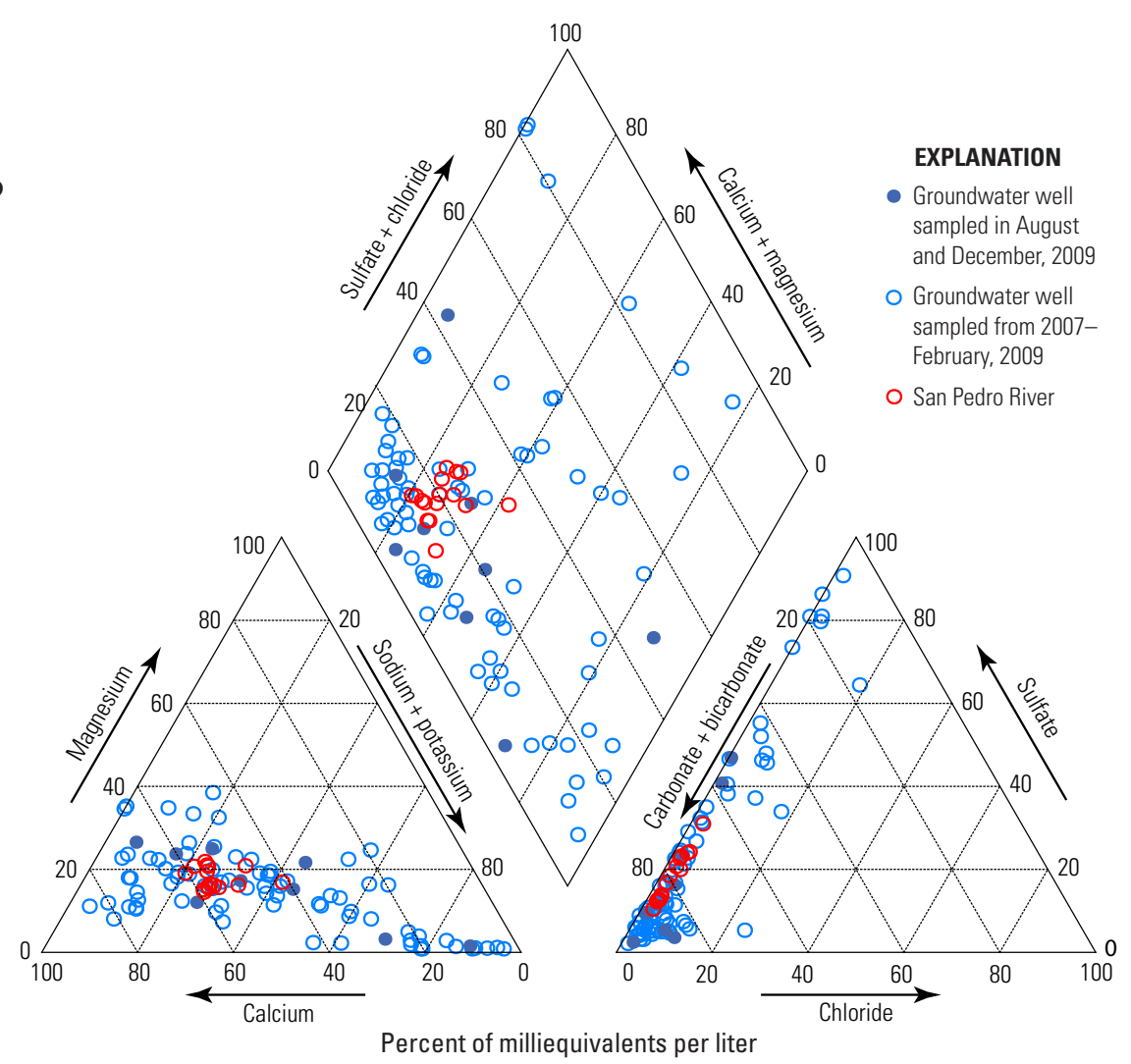

Figure 37. Piper diagram showing relative ionic composition of surface water and groundwater in the middle San Pedro Watershed.

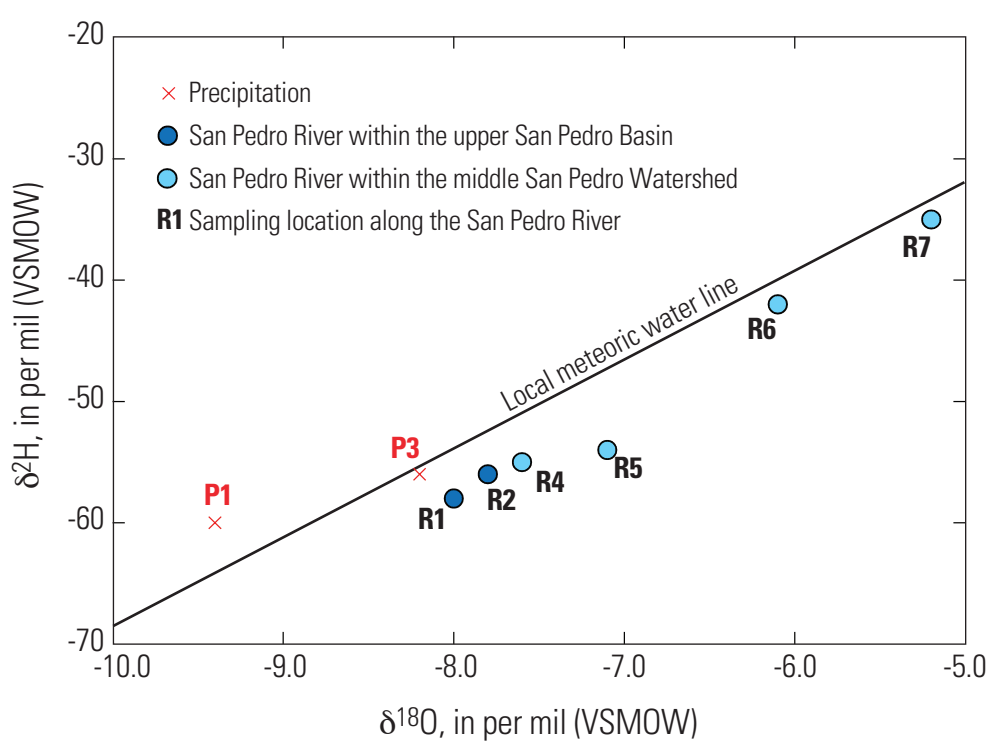

Figure 38. Plot showing $\delta^{18} 0$ and $\delta^{2} \mathrm{H}$ values from the San Pedro River collected in August 2008. Precipitation and surface-water sampling locations are shown in figure 39. Isotopic compositions are calculated relative to Vienna Standard Mean Ocean Water (VSMOW). 


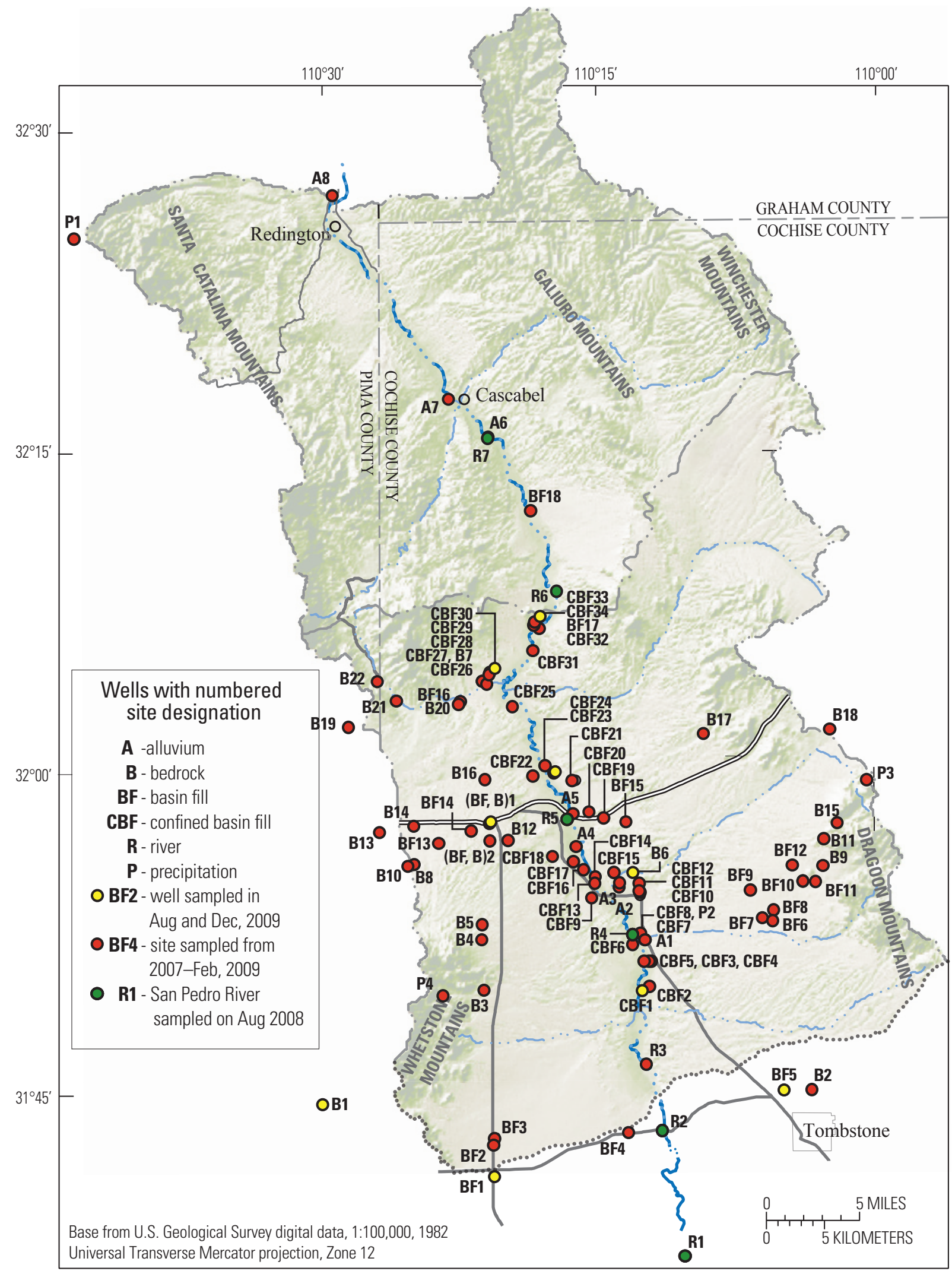

Figure 39. Map showing locations of groundwater and surface water sampling sites in the middle San Pedro Watershed and the designated hydrogeologic unit for the sampled well. 
Diablo Troilite, CDT) in this system suggest that sources of sulfate to the bedrock aquifer are rain water and gypsum dissolution (fig. 42). Precipitation measured in the Tucson Basin had a $\delta^{34} \mathrm{~S}$ value of 4.9 per mil $(\mathrm{Gu}, 2005)$, while Permian gypsum from the Epitaph Formation in the Winchester and Dragoon Mountains had $\delta^{34}$ S 11.7 per mil (Burtell, 1989).

Water in the basin fill aquifer shows some evidence of modern recharge, as only 4 of 12 samples analyzed for tritium are below the detection limit (fig. 40). Five wells analyzed for ${ }^{14} \mathrm{C}$ have moderate average values ( $48.5 \mathrm{pmc}$; fig. 41 ). The samples with ${ }^{14} \mathrm{C}$ values lower than $35 \mathrm{pmc}$ also have low calcium/strontium ratios (32.5 to 54.9, indicating long residence time and the potential for increased water-rock interaction (fig. 41). The sulfate/chloride ratios (average 6.12) were moderate to low for the basin-fill aquifer and only a few samples exceeded the EPA secondary drinking-water standard (SMCL) for fluoride of 2 $\mathrm{mg} / \mathrm{L}$ (average $1.2 \mathrm{mg} / \mathrm{L}$; fig. 36). Average oxygen and hydrogen isotope values for the basin-fill aquifer $\left(-6,152\right.$ per mil $\delta^{2} \mathrm{H}$ and -8.87 per mil $\delta^{18} \mathrm{O}$ ) plot between the bedrock and confined basin fill values (fig. 35 ) and suggest that recharge to the basin fill aquifer is from multiple seasons and altitudes. Sulfur isotopes (-8.4 to 13.3 per mil $\delta^{34} \mathrm{~S} \mathrm{CDT}$ ) suggest that sources of sulfate in this system are a mixture of Permian gypsum and rainwater (fig. 42).

Analyses of water samples from the confined basin-fill aquifer do not indicate a significant amount of modern recharge, because 6 of the 13 samples analyzed for tritium are at or below the detection limit while only 3 of the 13 samples have tritium values greater than 1 tritium unit, TU (fig. 40). Carbon-14 values in 16 of the 17 samples were less than $30 \mathrm{pmc}$ and averaged 16.1 pmc compared to only one sample (CBF 32) which was at $95.9 \mathrm{pmc}$ and also had the greatest tritium value (4.9 TU) from the confined basin-fill aquifer samples (figs. 40 and 41). Water sampled from the confined aquifer exhibit low $\mathrm{Ca} / \mathrm{Sr}$ ratios (average 34.4), indicating long residence time and the potential for increased water-rock interaction (fig. 41). Further evidence for increased water-rock interaction is seen in high sulfate/chloride ratios (average 9.8) and higher amounts of fluoride (average $2.7 \mathrm{mg} / \mathrm{L}$ ) (fig. 36). Average oxygen and hydrogen isotopes ( -58 per mil $\delta^{2} \mathrm{H}$ and -8.4 per mil $\delta^{18} \mathrm{O}$ ) suggest that recharge to the confined aquifer is from multiple seasons and altitudes (fig. 35). Sulfur isotopes ( -10.7 to 10.7 per mil $\left.\delta^{34} \mathrm{~S} C D T\right)$ suggest that sources of sulfate in this system are a mixture of Permian gypsum and rainwater (fig. 42).

The alluvial aquifer is primarily recharged by modern water, as suggested by relatively high tritium values ( 2.5 to $3.3 \mathrm{TU})$ in all but one sample ( $<0.5 \mathrm{TU}$; fig. 40$)$. Average oxygen and hydrogen isotopic values $\left(-54\right.$ per mil $\delta^{2} \mathrm{H}$ and -7.7 per mil $\delta^{18} \mathrm{O}$ ) suggest that the alluvial aquifer is recharged primarily during the summer monsoon season by floodwater in the river (fig. 35). The alluvial aquifer samples generally have moderate average ion ratios: calcium/strontium (72.3), sulfate/ chloride (9.1), and all but one sample $(5.97 \mathrm{mg} / \mathrm{L})$ contained low levels of fluoride ( 0.49 to $2.1 \mathrm{mg} / \mathrm{L})$. Sulfur isotopes (2.6 to 9.3 per mil CDT) help to constrain the source of sulfate in the alluvial aquifer; river water contributes most of the sulfate to the near-stream alluvial system (fig. 42).

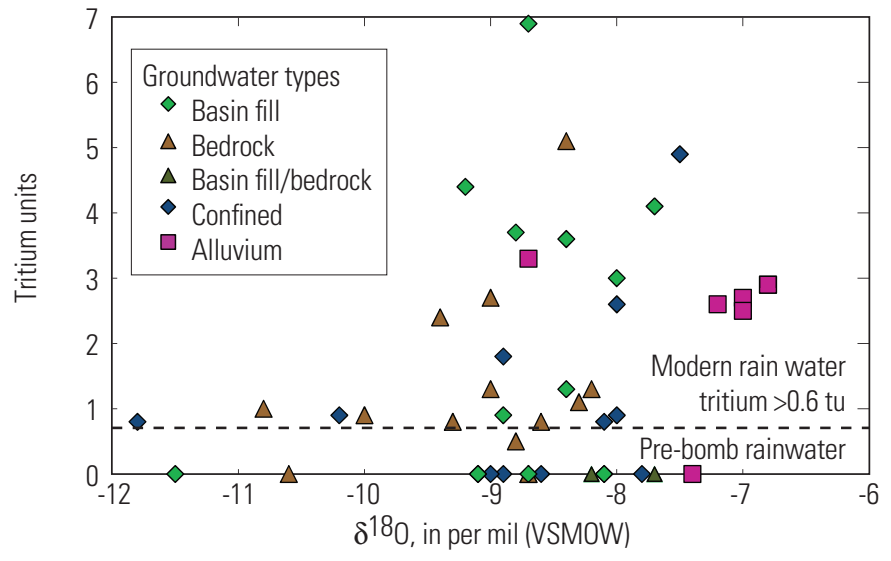

Figure 40. Plot showing tritium values in groundwater samples from the middle San Pedro Watershed, plotted against $\delta^{18} 0$. Isotopic ratios are presented as a per mil deviation from Vienna Standard Mean Ocean Water (VSMOW).

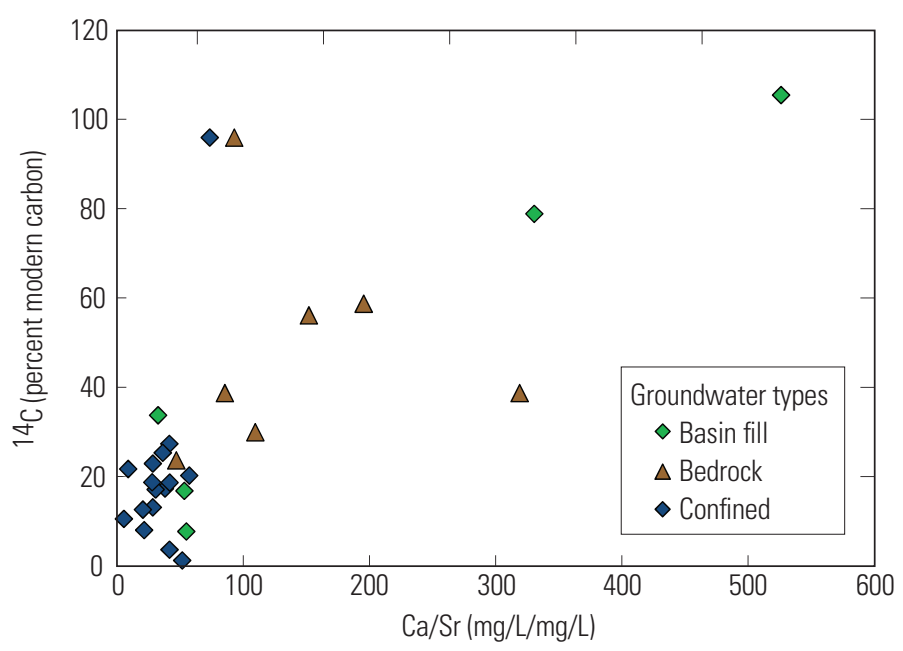

Figure 41. Plot showing calcium and strontium ratios plotted against ${ }^{14} \mathrm{C}$ in groundwater samples from the middle San Pedro Watershed.

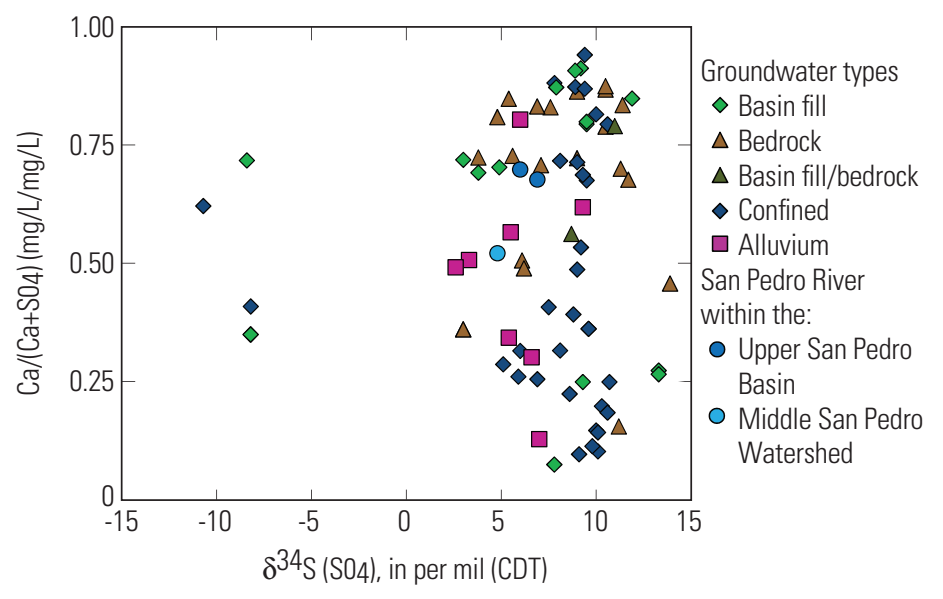

Figure 42. Plot showing sulfur isotope ratios $\left(\delta^{34} S\right)$ in groundwater and surface water, plotted against calcium bicarbonate relative to calcium over calcium plus sulfate ratio in the middle San Pedro Watershed. Isotopic compositions are calculated as a per mil deviation from the Canyon Diablo Troilite (CDT). 
Table 15. Differences in physical and mineral characteristics and in constituent concentrations in groundwater samples collected in the middle San Pedro Watershed in 1996 and 2009.

$\left[{ }^{\circ} \mathrm{C}\right.$, degrees Celsius; $\mu \mathrm{g} / \mathrm{L}$, micrograms per liter; $\mathrm{mg} / \mathrm{L}$, milligrams per liter; $\mu \mathrm{S} / \mathrm{cm}$, microsiemens per centimeter $]$

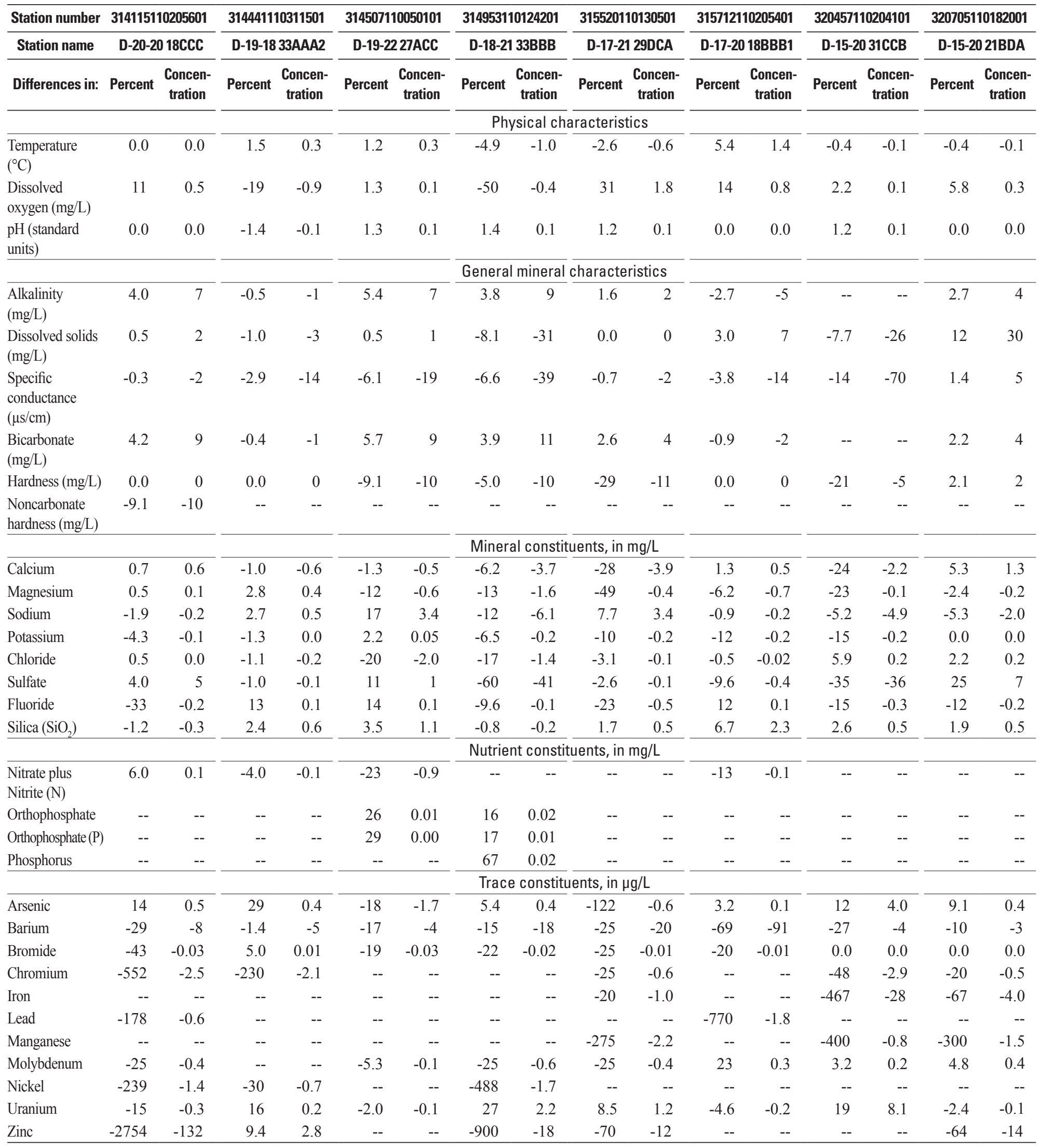


Two samples from the confined aquifer contain low ${ }^{14} \mathrm{C}$ values (13.1 and $20.2 \mathrm{pmc}$ ), but elevated tritium (1.8 and $2.6 \mathrm{TU}$; figs. 40 and 41). These two samples (CBF14 and $\mathrm{CBF} 16)$ are located near a gaining portion of the river by St. David, which may indicate an upgradient input of younger water. In addition, one well in the alluvial aquifer (A1) demonstrates tritium below the detection limit and high fluoride concentration and is located near a gaining portion of the river. These anomalous wells may indicate mixing between the confined aquifer and the alluvial aquifer.

\section{Water Quality}

Eight wells sampled in 1996 by Coes and others (1999) were resampled in 2009 using the same sampling protocols and laboratory analytical methods. The values of the majority of the analytes did not change substantially (table 15). Several constituents exceeded the drinking-water-quality standards determined by the U.S. Environmental Protection Agency (EPA; U.S. Environmental Protection Agency, 2007; table 16). Distribution of water quality exceedances are presented in figure 43 . Fluoride concentrations in the confined basin fill aquifer were substantially greater than the other aquifers (fig. 44). Arsenic and fluoride are contaminants of concern in the San Pedro Watershed and are common in concentrations above the EPA drinking-water-quality standards in southwestern alluvial basins (Robertson, 1991).

Quality-assurance samples (blank and replicate samples) were collected during sampling, and the results are presented in tables 17 and 18, respectively. The blank collected in 2009 contained only one constituent (lead) with a detectable value. The value was between the method detection level of 0.03 and the method reporting level of 0.06 and was given a value of E 0.059 (table 17); the E stands for estimated. The blanks collected in 2008 contained detectable amounts of chloride (2.4 and $2.5 \mathrm{mg} / \mathrm{L})$, nitrate $(1.2 \mathrm{mg} / \mathrm{L})$, potassium $(0.09 \mathrm{mg} / \mathrm{L})$, strontium $(0.85 \mathrm{mg} / \mathrm{L})$, and sulfate $(2.4$ and $2.9 \mathrm{mg} / \mathrm{L})$ (table 17). The blank detections may indicate potential bias in environmental sample values, especially for environmental samples with concentrations less than 10 times the blank concentration. Some environmental sample concentrations of chloride, nitrate, and sulfate are within the 10 times blank concentration range and these values should be used with caution.

Replicate sample results are presented in table 18 . The replicate collected in 2009 at site BF1 was very similar (less than 15 percent different) compared to the environmental sample for all constituents analyzed except for zinc, which was 94 percent different. Replicate samples collected in 2008 at sites B9, CBF15, and CBF22 (table 18) were very similar (less than 15 percent different) compared to the environmental sample for most constituents analyzed except for fluoride at 21 percent (CBF22) and potassium at 34 percent different (B9). The absolute concentration difference between the environmental and replicate sample for these two samples was small for fluoride $(0.12 \mathrm{mg} / \mathrm{L})$ and potassium $(0.8 \mathrm{mg} / \mathrm{L})$. Eight samples were
Table 16. U.S. Environmental Protection Agency drinking-waterquality standards.

[Constituents are dissolved and are reported in micrograms per liter unless otherwise noted; MCL, Maximum Contaminant Level; mg/L, milligrams per liter; --, no standard]

\begin{tabular}{|c|c|c|}
\hline \multirow{2}{*}{ Constituent } & \multicolumn{2}{|c|}{ U.S. Environmental Protection Agency ${ }^{1}$} \\
\hline & Primary MCL & Secondary MCL \\
\hline Aluminum & -- & $50-200$ \\
\hline Antimony & 6 & -- \\
\hline Arsenic & 10 & -- \\
\hline Barium & 2,000 & -- \\
\hline Beryllium & 4 & -- \\
\hline Cadmium & 5 & -- \\
\hline Chloride (mg/L) & -- & 250 \\
\hline Chromium & 100 & -- \\
\hline Copper & 1,300 & 1,000 \\
\hline Fluoride (mg/L) & 4 & 2 \\
\hline Iron & -- & 300 \\
\hline Lead & 15 & -- \\
\hline Manganese & -- & 50 \\
\hline Nitrate $(\mathrm{mg} / \mathrm{L})$ & 10 & -- \\
\hline Nitrite $(\mathrm{mg} / \mathrm{L})$ & 1 & -- \\
\hline $\mathrm{pH}$ & -- & $6.5-8.5$ \\
\hline Selenium & 50 & -- \\
\hline Silver & -- & 100 \\
\hline Sulfate (mg/L) & -- & 250 \\
\hline Thallium & 2 & -- \\
\hline Total Dissolved Solids (mg/L) & -- & 500 \\
\hline Uranium & 30 & -- \\
\hline Zinc & -- & 5,000 \\
\hline
\end{tabular}

${ }^{1}$ Drinking-water-quality standards (U.S. Environment Protection Agency, 2007)

sent to both the U.S. Geological Survey National Water Quality Laboratory and the University of Arizona Department of Hydrology and Water Resources Laboratory. Values calculated by the two laboratories differed by more than 15 percent for several constituents: calcium, magnesium, sodium, potassium, chloride, sulfate, fluoride, silica, strontium and bromide (table 19). Large-percentage differences for fluoride and bromide are due to low concentrations and therefore have small magnitudes of actual concentration differences (table 19).

\section{Study Limitations and Considerations for Future Data Collection and Analysis}

The hydrologic investigation described in this report represents the most comprehensive baseline set of available hydrologic and geochemical data in the middle San Pedro Watershed to date. The data collected describe the climate, 
Table 17. Results of analyses of blank samples. Samples collected in 2008 were analyzed by University of Arizona Department of Hydrology and Water Resources Laboratory. The sample collected in $\mathbf{2 0 0 9}$ was analyzed by the U.S. Geological Survey National Water Quality Laboratory.

$[\mu \mathrm{g} / \mathrm{L}$, micrograms per liter; $\mathrm{mg} / \mathrm{L}$, milligrams per liter; $\mu \mathrm{S} / \mathrm{cm}$, microsiemens per centimeter]

\begin{tabular}{|c|c|c|c|c|}
\hline Station ID & & 315712110205401 & 315547110025301 & 315434110064501 \\
\hline Station name & & (BF, B)1 & B9 & BF9 \\
\hline Sample date & & 08/07/2009 & $3 / 16 / 08$ & $6 / 16 / 08$ \\
\hline Sample time & & 9:40 & & \\
\hline Constituent & Units & & & \\
\hline Aluminum, dissolved & $\mu \mathrm{g} / \mathrm{L}$ & $<4$ & & \\
\hline Ammonia, dissolved & $\mathrm{mg} / \mathrm{L}$ & $<0.02$ & & \\
\hline Antimony, dissolved & $\mu \mathrm{g} / \mathrm{L}$ & $<0.04$ & & \\
\hline Arsenic, dissolved & $\mu \mathrm{g} / \mathrm{L}$ & $<0.06$ & & \\
\hline Barium, dissolved & $\mu \mathrm{g} / \mathrm{L}$ & $<0.4$ & & \\
\hline Beryllium, dissolved & $\mu \mathrm{g} / \mathrm{L}$ & $<0.02$ & & \\
\hline Boron, dissolved & $\mu \mathrm{g} / \mathrm{L}$ & & $<5$ & $<5$ \\
\hline Bromide, dissolved & $\mathrm{mg} / \mathrm{L}$ & $<0.02$ & $<0.01$ & $<0.01$ \\
\hline Cadmium, dissolved & $\mu \mathrm{g} / \mathrm{L}$ & $<0.02$ & & \\
\hline Calcium, dissolved & $\mathrm{mg} / \mathrm{L}$ & $<0.02$ & $<0.1$ & $<0.1$ \\
\hline Chloride, dissolved & $\mathrm{mg} / \mathrm{L}$ & $<0.12$ & 2.5 & 2.4 \\
\hline Cobalt, dissolved & $\mu \mathrm{g} / \mathrm{L}$ & $<0.02$ & & \\
\hline Copper, dissolved & $\mu \mathrm{g} / \mathrm{L}$ & $<1$ & & \\
\hline Chromium, dissolved & $\mu \mathrm{g} / \mathrm{L}$ & $<0.12$ & & \\
\hline Dissolved solids & $\mathrm{mg} / \mathrm{L}$ & $<10$ & & \\
\hline Fluoride, dissolved & $\mathrm{mg} / \mathrm{L}$ & $<0.08$ & $<0.05$ & $<0.05$ \\
\hline Iron, dissolved & $\mu \mathrm{g} / \mathrm{L}$ & $<4$ & & \\
\hline Lead, water, dissolved & $\mu \mathrm{g} / \mathrm{L}$ & E0.059 & & \\
\hline Magnesium, dissolved & $\mathrm{mg} / \mathrm{L}$ & $<0.012$ & $<0.1$ & $<0.1$ \\
\hline Manganese, dissolved & $\mu \mathrm{g} / \mathrm{L}$ & $<0.2$ & & \\
\hline Molybdenum, dissolved & $\mu \mathrm{g} / \mathrm{L}$ & $<0.02$ & & \\
\hline Nickel, dissolved & $\mu \mathrm{g} / \mathrm{L}$ & $<0.12$ & & \\
\hline Nitrate as $\mathrm{N}$, dissolved & $\mathrm{mg} / \mathrm{L}$ & $<0.04$ & $<0.1$ & 1.2 \\
\hline Nitrite, dissolved & $\mathrm{mg} / \mathrm{L}$ & $<0.002$ & & \\
\hline Nitrogen, dissolved & $\mathrm{mg} / \mathrm{L}$ & $<0.1$ & & \\
\hline Orthophosphate, dissolved & $\mathrm{mg} / \mathrm{L}$ & $<0.008$ & & \\
\hline pH (lab) & & 7.9 & & \\
\hline Phosphorus, dissolved & $\mathrm{mg} / \mathrm{L}$ & $<0.006$ & & \\
\hline Potassium, dissolved & $\mathrm{mg} / \mathrm{L}$ & $<0.06$ & $<0.1$ & 0.09 \\
\hline Dissolved Solids & $\mathrm{mg} / \mathrm{L}$ & $<10$ & & \\
\hline Selenium, dissolved & $\mu \mathrm{g} / \mathrm{L}$ & $<0.06$ & & \\
\hline Silica, dissolved & $\mathrm{mg} / \mathrm{L}$ & $<0.02$ & & \\
\hline Silver, dissolved & $\mu \mathrm{g} / \mathrm{L}$ & $<0.008$ & & \\
\hline Sodium, dissolved & $\mathrm{mg} / \mathrm{L}$ & $<0.12$ & $<0.1$ & $<0.1$ \\
\hline Specific conductance (lab) & $\mu \mathrm{S} / \mathrm{cm}$ & $<5$ & & \\
\hline Strontium, dissolved & $\mu \mathrm{g} / \mathrm{L}$ & & $<5$ & 0.85 \\
\hline Sulfate, dissolved & $\mathrm{mg} / \mathrm{L}$ & $<0.18$ & 2.4 & 2.9 \\
\hline Uranium, dissolved & $\mu \mathrm{g} / \mathrm{L}$ & $<0.006$ & & \\
\hline Zinc, dissolved & $\mu \mathrm{g} / \mathrm{L}$ & $<2$ & & \\
\hline
\end{tabular}


Table 18. Results of analyses of replicate samples. Samples analyzed at the University of Arizona Department of Hydrology and Water Resources Laboratory and the U.S. Geological Survey National Water Quality Laboratory.

$[\mu \mathrm{g} / \mathrm{L}$, micrograms per liter; $\mathrm{mg} / \mathrm{L}$, milligrams per liter; $\mu \mathrm{S} / \mathrm{cm}$, microsiemens per centimeter]

\begin{tabular}{|c|c|c|c|c|c|c|c|c|c|}
\hline \multicolumn{2}{|l|}{ Station ID } & \multirow{2}{*}{\multicolumn{2}{|c|}{$\begin{array}{c}314115110205601 \\
\text { BF1 }\end{array}$}} & \multicolumn{2}{|c|}{315955110183101} & \multicolumn{2}{|c|}{315547110025301} & \multicolumn{2}{|c|}{315525110141001} \\
\hline \multicolumn{2}{|l|}{ Station name } & & & \multirow{2}{*}{\multicolumn{2}{|c|}{$\begin{array}{l}\text { CBF22 } \\
2 / 10 / 08\end{array}$}} & \multicolumn{2}{|c|}{ B9 } & \multicolumn{2}{|c|}{ CBF15 } \\
\hline \multicolumn{2}{|l|}{ Sample date } & \multicolumn{2}{|c|}{$8 / 11 / 09$} & & & $3 / 11$ & & $6 / 13$ & \\
\hline Sample time & & $14: 30$ & $14: 35$ & $10: 00$ & 10:05 & $14: 30$ & $14: 35$ & 15:00 & 15:05 \\
\hline Constituent & Units & & & & & & & & \\
\hline Alkalinity as $\mathrm{CaCO}_{3}$ & $\mathrm{mg} / \mathrm{L}$ & 177 & 178 & 183 & 178 & 121 & 135 & 120 & 120 \\
\hline Aluminum, dissolved & $\mu \mathrm{g} / \mathrm{L}$ & $<4$ & $<4$ & & & & & & \\
\hline Ammonia, dissolved & $\mathrm{mg} / \mathrm{L}$ & $<0.02$ & $<0.02$ & & & & & & \\
\hline Antimony, dissolved & $\mu \mathrm{g} / \mathrm{L}$ & 0.057 & 0.061 & & & & & & \\
\hline Arsenic, dissolved & $\mu \mathrm{g} / \mathrm{L}$ & 3.5 & 3.7 & & & & & & \\
\hline Barium, dissolved & $\mu \mathrm{g} / \mathrm{L}$ & 28.3 & 28.5 & & & & & & \\
\hline Beryllium, dissolved & $\mu \mathrm{g} / \mathrm{L}$ & $<0.02$ & $<0.02$ & & & & & & \\
\hline Boron, dissolved & $\mu \mathrm{g} / \mathrm{L}$ & & & 40 & 34 & & & 65 & 72 \\
\hline Bromide, dissolved & $\mathrm{mg} / \mathrm{L}$ & 0.07 & 0.08 & 0.07 & 0.06 & 0.16 & 0.16 & 0.11 & 0.12 \\
\hline Cadmium, dissolved & $\mu \mathrm{g} / \mathrm{L}$ & $<0.02$ & $<0.02$ & & & & & & \\
\hline Calcium, dissolved & $\mathrm{mg} / \mathrm{L}$ & 82.6 & 82.8 & 38 & 38 & 21 & 22 & 8.3 & 8.3 \\
\hline Chloride, dissolved & $\mathrm{mg} / \mathrm{L}$ & 6.4 & 6.4 & 5.6 & 5.6 & 18 & 16 & 5.8 & 5.8 \\
\hline Cobalt, dissolved & $\mu \mathrm{g} / \mathrm{L}$ & 0.14 & 0.14 & & & & & & \\
\hline Copper, dissolved & $\mu \mathrm{g} / \mathrm{L}$ & $<1$ & E0.57 & & & & & & \\
\hline Chromium, dissolved & $\mu \mathrm{g} / \mathrm{L}$ & 0.46 & 0.48 & & & & & & \\
\hline Dissolved solids & $\mathrm{mg} / \mathrm{L}$ & 405 & 412 & & & & & & \\
\hline Fluoride, dissolved & $\mathrm{mg} / \mathrm{L}$ & 0.45 & 0.49 & 0.59 & 0.47 & 7.7 & 7.4 & 5.6 & 5.6 \\
\hline Iron, dissolved & $\mu \mathrm{g} / \mathrm{L}$ & $<4$ & $<4$ & & & & & & \\
\hline Lead, water, dissolved & $\mu \mathrm{g} / \mathrm{L}$ & 0.36 & 0.37 & & & & & & \\
\hline Magnesium, dissolved & $\mathrm{mg} / \mathrm{L}$ & 20.1 & 20.2 & 6.8 & 7.0 & 0.51 & 0.53 & 0.78 & 0.76 \\
\hline Manganese, dissolved & $\mu \mathrm{g} / \mathrm{L}$ & $<0.2$ & $<0.2$ & & & & & & \\
\hline Molybdenum, dissolved & $\mu \mathrm{g} / \mathrm{L}$ & 1.6 & 1.7 & & & & & & \\
\hline Nickel, dissolved & $\mu \mathrm{g} / \mathrm{L}$ & 0.59 & 0.62 & & & & & & \\
\hline Nitrate as $\mathrm{N}$, dissolved & $\mathrm{mg} / \mathrm{L}$ & 1.2 & 1.2 & 1.9 & 2.0 & 1.1 & 1.0 & 3.0 & 3.1 \\
\hline Nitrite, dissolved & $\mathrm{mg} / \mathrm{L}$ & $<0.002$ & $<0.002$ & & & & & & \\
\hline Nitrogen, dissolved & $\mathrm{mg} / \mathrm{L}$ & 1.1 & 1.2 & & & & & & \\
\hline Orthophosphate, dissolved & $\mathrm{mg} / \mathrm{L}$ & 0.01 & 0.01 & & & & & & \\
\hline $\mathrm{pH}(\mathrm{lab})$ & & 7.5 & 7.5 & & & & & & \\
\hline Phosphorus, dissolved & $\mathrm{mg} / \mathrm{L}$ & $<0.006$ & $<0.006$ & & & & & & \\
\hline Potassium, dissolved & $\mathrm{mg} / \mathrm{L}$ & 2.1 & 2.1 & 3.0 & 3.0 & 1.4 & 2.2 & 2.3 & 2.3 \\
\hline Selenium, dissolved & $\mu \mathrm{g} / \mathrm{L}$ & 1.3 & 1.3 & & & & & & \\
\hline Silica, dissolved & $\mathrm{mg} / \mathrm{L}$ & 26 & 26 & & & & & & \\
\hline Silver, dissolved & $\mu \mathrm{g} / \mathrm{L}$ & $<0.008$ & $<0.008$ & & & & & & \\
\hline Sodium, dissolved & $\mathrm{mg} / \mathrm{L}$ & 11 & 11 & 43 & 44 & 104 & 105 & 62 & 62 \\
\hline Specific conductance (lab) & $\mu \mathrm{S} / \mathrm{cm}$ & 606 & 605 & & & & & & \\
\hline Strontium, dissolved & $\mu \mathrm{g} / \mathrm{L}$ & & & 913 & 942 & 454 & 459 & 939 & 964 \\
\hline Sulfate, dissolved & $\mathrm{mg} / \mathrm{L}$ & 125 & 125 & 17 & 16 & 116 & 112 & 18 & 18 \\
\hline Uranium, dissolved & $\mu \mathrm{g} / \mathrm{L}$ & 1.7 & 1.8 & & & & & & \\
\hline Zinc, dissolved & $\mu \mathrm{g} / \mathrm{L}$ & 4.8 & 9.3 & & & & & & \\
\hline
\end{tabular}


Table 19. Differences in constituent concentrations between samples analyzed at the U.S. Geological Survey National Water Quality Laboratory and at the University of Arizona Department of Hydrology and Water Resources Laboratories.

[mg/L, milligrams per liter; $\mu \mathrm{g} / \mathrm{L}$, micrograms per liter]

Percent (\%) difference

\begin{tabular}{|c|c|c|c|c|c|c|c|c|c|c|c|c|c|c|}
\hline $\begin{array}{l}\text { Station } \\
\text { name }\end{array}$ & Station ID & $\begin{array}{c}\text { Sample } \\
\text { date }\end{array}$ & pH & $\begin{array}{c}\text { Calcium } \\
\text { (mg/L) }\end{array}$ & $\begin{array}{l}\text { Magnesium } \\
(\mathrm{mg} / \mathrm{L})\end{array}$ & $\begin{array}{c}\text { Sodium } \\
(\mathrm{mg} / \mathrm{L})\end{array}$ & $\begin{array}{c}\text { Potassium } \\
\text { (mg/L) }\end{array}$ & $\begin{array}{c}\text { Chloride } \\
\text { (mg/L) }\end{array}$ & $\begin{array}{l}\text { Sulfate } \\
(\mathrm{mg} / \mathrm{L})\end{array}$ & $\begin{array}{c}\text { Fluoride } \\
\text { (mg/L) }\end{array}$ & $\begin{array}{l}\text { Silica } \\
\text { (mg/L) }\end{array}$ & $\begin{array}{c}\text { Strontium } \\
\text { ( } \mu \mathrm{g} / \mathrm{L})\end{array}$ & $\begin{array}{c}\text { Bromide } \\
\text { (mg/L) }\end{array}$ & $\begin{array}{c}\text { Alkalinity } \\
\text { (mg/L) }\end{array}$ \\
\hline A7 & 321727110230201 & $1 / 10 / 09$ & $0 \%$ & $24 \%$ & $26 \%$ & $-37 \%$ & $-4 \%$ & $40 \%$ & $-6 \%$ & $18 \%$ & $-43 \%$ & $-7 \%$ & $88 \%$ & $-2 \%$ \\
\hline CBF24 & 320024110175401 & $6 / 18 / 08$ & $2 \%$ & $15 \%$ & $9 \%$ & $8 \%$ & $0 \%$ & $22 \%$ & $-7 \%$ & $20 \%$ & $-47 \%$ & $-7 \%$ & $194 \%$ & $13 \%$ \\
\hline A8 & 322658110292101 & $1 / 10 / 09$ & $-1 \%$ & $20 \%$ & $12 \%$ & $-32 \%$ & $-4 \%$ & $4 \%$ & $-3 \%$ & $7 \%$ & $-46 \%$ & $-12 \%$ & $49 \%$ & $-5 \%$ \\
\hline BF11 & 315504110030501 & $11 / 8 / 08$ & $8 \%$ & $8 \%$ & $2 \%$ & $-39 \%$ & $-10 \%$ & $10 \%$ & $-2 \%$ & $3 \%$ & $-53 \%$ & $-18 \%$ & $21 \%$ & $-3 \%$ \\
\hline BF15 & 315745110133001 & $11 / 8 / 08$ & $10 \%$ & $3 \%$ & $8 \%$ & $-10 \%$ & $11 \%$ & $48 \%$ & $34 \%$ & $4 \%$ & $-50 \%$ & $3 \%$ & $40 \%$ & $6 \%$ \\
\hline $\mathrm{B} 10$ & 315551110250101 & $5 / 14 / 08$ & $2 \%$ & $8 \%$ & $24 \%$ & $3 \%$ & $1 \%$ & $-3 \%$ & $0 \%$ & $6 \%$ & $-47 \%$ & $0 \%$ & $50 \%$ & $3 \%$ \\
\hline $\begin{array}{c}\text { Station } \\
\text { name }\end{array}$ & Station ID & $\begin{array}{c}\text { Sample } \\
\text { date }\end{array}$ & pH & $\begin{array}{c}\text { Calcium } \\
\text { (mg/L) }\end{array}$ & $\begin{array}{l}\text { Magnesium } \\
(\mathrm{mg} / \mathrm{L})\end{array}$ & $\begin{array}{c}\text { Sodium } \\
\text { (mg/L) }\end{array}$ & $\begin{array}{l}\text { Potassium } \\
\text { (mg/L) }\end{array}$ & $\begin{array}{c}\text { Chloride } \\
\text { (mg/L) }\end{array}$ & $\begin{array}{l}\text { Sulfate } \\
\text { (mg/L) }\end{array}$ & $\begin{array}{c}\text { Fluoride } \\
\text { (mg/L) }\end{array}$ & $\begin{array}{l}\text { Silica } \\
\text { (mg/L) }\end{array}$ & $\begin{array}{c}\text { Strontium } \\
(\mu \mathrm{g} / \mathrm{L})\end{array}$ & $\begin{array}{c}\text { Bromide } \\
\text { (mg/L) }\end{array}$ & $\begin{array}{c}\text { Alkalinity } \\
\text { (mg/L) }\end{array}$ \\
\hline A7 & 321727110230201 & $1 / 10 / 09$ & 0.02 & 19 & 2.9 & 8.7 & 0.16 & 1.6 & 1.6 & 0.09 & 9.9 & 41 & 0.04 & 6.3 \\
\hline CBF24 & 320024110175401 & $6 / 18 / 08$ & 0.17 & 4.4 & 0.50 & 4.3 & 0.00 & 0.99 & 2.5 & 0.09 & 15 & 70 & 0.08 & 23 \\
\hline A8 & 322658110292101 & $1 / 10 / 09$ & 0.07 & 8.1 & 0.86 & 12 & 0.17 & 0.46 & 1.1 & 0.06 & 8.3 & 43 & 0.04 & 9.4 \\
\hline A6 & 321542110205301 & $1 / 10 / 09$ & 0.21 & 6.3 & 2.3 & 17 & 1.1 & 0.91 & 10 & 0.06 & 11 & 4.4 & 0.01 & 16 \\
\hline
\end{tabular}

surface-water conditions, groundwater conditions, hydrochemistry and water quality, and further the understanding of the movement of groundwater in the middle San Pedro Watershed. The development of the middle San Pedro Watershed groundwater budget quantifies the current relationship between inflows and outflows from the aquifer system. The results of this investigation also helped identify data gaps and limitations of previous models used for representing hydrologic processes in the watershed.

The distributed-parameter water-balance model underestimated natural recharge in the Benson subarea on the basis of previous investigations and in comparison to the other groundwater budget components. This result is probably a consequence of the model's limited representation of streamflow infiltration in ephemeral channels as well as the model's use of the monthly calculated potential ET value. The collection of additional streamflow and precipitation data from ephemeral channels in the Benson subarea could reduce uncertainty in the model results and improve the understanding of recharge processes in the subarea.

In this study, $\mathrm{ET}_{\mathrm{gw}}$ is the largest groundwater outflow component from both subareas and the uncertainty in the $\mathrm{ET}_{\mathrm{gw}}$ estimates arise because $\mathrm{ET}_{\mathrm{gw}}$ is difficult to measure directly at the watershed scale. The $\mathrm{ET}_{\mathrm{gw}}$ estimates could be overestimated by as much as 22 percent due to an energy closure error. Even if compensated for the energy 
closure error, the $\mathrm{ET}_{\mathrm{gw}}$ estimates would still be the largest groundwater outflow component from both subareas. The methodology used in this investigation utilized remote sensing data at 16-day intervals combined with direct measurements of ET from flux towers in the Upper San Pedro Basin. The establishment of flux towers in the middle San Pedro Watershed could be used to verify the calculated $\mathrm{ET}_{\mathrm{gw}}$ rates and improve the estimates of consumptive use of irrigated crops. The collection of precipitation data from riparian areas could also reduce the uncertainty in the estimated rates. Stable isotope collection could also be used to distinguish the source of water for $\mathrm{ET}_{\mathrm{gw}}$ and further reduce uncertainty.

Estimates of groundwater underflow into and out of the two subareas also have high uncertainties. Additional hydrogeologic data such as the saturated thickness, hydraulic conductivity, and storage values collected near the upstream and downstream ends of the watershed would help quantify the rates of groundwater underflow. These data could then be incorporated into a flow model for simulation. The underflow into the Benson subarea from the Sierra Vista Subwatershed has been estimated as part of other investigations and might have less uncertainty. The uncertainty of the underflow at the Narrows could also be reduced with additional hydrologic information from that area, including more sampling of the wells to the north and south of the Narrows to better define groundwater sources and map the spatial distribution of groundwater underflow. Additional well sampling at the other underflow locations could be helpful in constraining those values, although underflow would be best estimated with a groundwater flow model. The amount of water that leaves the watershed as underflow is highly uncertain, primarily because of the arbitrary downstream boundary of the watershed.

Previous investigators have focused on the area from the Narrows to the confluence of the Gila River.

The uncertainty in water-use estimates arises from the methods used to estimate the groundwater withdrawals. The 1991-2009 estimates of the groundwater withdrawals for municipal and industrial uses are derived from values supplied by the water providers and industrial operations and have a higher degree of accuracy. Irrigation data estimated for 2000-2009 is based on verification of the crops planted and irrigation systems. The irrigation data could be improved if surface-water diversions from the San Pedro River were regularly measured. Total irrigation withdrawals include both surface-water and groundwater withdrawals; having a value for surface-water withdrawals would improve the estimation of actual groundwater withdrawals. Water-use estimates for before 1980 were calculated based on U.S. Census data. In the Benson subarea a portion of the population resides near Benson on a seasonal basis, and this may not be reflected in the U.S. Census data.

The self-supplied domestic per capita water use was estimated with a limited data set and more water use data is needed to reduce the uncertainty in that information. The self-supplied domestic population is not accurately known in both subareas. The self-supplied domestic groundwater withdrawals also were estimated based on the assumption that each home irrigated at least one acre of a combination of grass and garden. In total, additional withdrawal information and population refinements are needed to reduce the uncertainty in these groundwater budget components. The incidental recharge value also has some uncertainty because it is primarily based on the irrigation withdrawals. Additional investigations and information such as the infiltration rates in the fields are needed to adequately estimate this term.

More sampling of surface water, groundwater, and precipitation is needed to improve the conceptual understanding of groundwater flow paths between recharge and discharge areas. Focused sampling of groundwater from the confined aquifer, specifically in areas where results of this study indicate mixing with the floodplain aquifer, would be especially useful. Age dating of groundwater along an east-west transect from bedrock wells in the mountain block towards the San Pedro River would provide a better understanding of groundwater residence time. Sampling wells in the floodplain aquifer after a large flood event and analysis for major ions and stable isotopes in relation to groundwater level changes would provide valuable information about riverbank storage. The collection of additional samples at multiple times each year could also be used to determine any seasonal trends in the movement of water in the watershed.

\section{Summary and Conclusions}

This report is the first comprehensive hydrologic analysis of the middle San Pedro Watershed. Examining existing data and collection of new data have greatly improved the understanding of the movement of water in the middle San Pedro Watershed. The hydrogeologic units and groundwater and surface water and the development of groundwater budgets for both subareas are described in this report. These groundwater budgets show the relative magnitudes of the inflow and outflow components and can serve as the baseline for comparison to any future hydrologic changes in the area. Important findings in this study include the identification of wetting and drying periods in the watershed, the decrease in annual streamflow in the San Pedro River, long-term changes in groundwater levels throughout the watershed and base flow at the streamgaging station at Charleston, and annual estimates of the groundwater component of $\left(\mathrm{ET}_{\mathrm{gw}}\right)$ in both subareas.

The analysis of streamflow, water levels from wells, and long-term precipitation at Tombstone gives an indication of how the groundwater system in the middle San Pedro Watershed responds to long-term variations in climate. On the basis of precipitation and base flow at Charleston, drying periods occurred from 1950-1980 and from 1995 to the present and a distinct wetting period occurred in the mid1980s through the mid-1990s. Water levels from five wells 
near the mountain front and wells in the unconfined parts of the lower basin fill show periods of recharge also consistent with the wetting periods in the mid-1980s and mid-1990s. Water levels in three wells near the San Pedro River showed the lowest water levels in the 1950s to mid-1960s and two wells showed increases in water levels in the 1980s.

The comparison of groundwater budgets developed for predevelopment and 2001-2009 time periods gives an indication of how the groundwater system has changed due to development in the middle San Pedro Watershed. The predevelopment outflow from the Benson subarea and the Narrows-Redington subareas of the watershed are $20.5 \mathrm{hm}^{3} / \mathrm{yr}$ and $14.8 \mathrm{hm}^{3} / \mathrm{yr}$, respectively. The largest outflow components in the Benson subarea are $\mathrm{ET}_{\mathrm{gw}}$ followed by stream base flow. In the Narrows-Redington subarea, the largest outflow component is stream base flow followed by $\mathrm{ET}_{\mathrm{gw}}$.

For the years 2001-2009, in the absence of groundwater pumping for irrigation, public supply, industrial, and selfsupplied domestic uses, the groundwater outflows from the Benson and Narrows-Redington subareas are $18.5 \mathrm{hm}^{3} / \mathrm{y}$ and $12.9 \mathrm{hm}^{3} / \mathrm{yr}$, respectively. The largest outflow component for

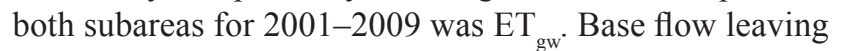
both subareas as of 2009 is now zero as groundwater is discharged only in select reaches of the San Pedro River and only for part of the year. It must be noted when comparing the groundwater budgets that the period 2001-2009 is drier than the long-term average and this could be one reason why the predevelopment outflows are greater than the natural outflows for 2001-2009. Another possible reason for the decrease in the natural outflows is increasing $\mathrm{ET}_{\mathrm{gw}}$ in the middle San Pedro Watershed, which will reduce the overall groundwater available for natural outflow.

For 2001-2009, the average annual groundwater withdrawal for water use (excluding $\mathrm{ET}_{\mathrm{gw}}$ ) was $9.1 \mathrm{hm}^{3} / \mathrm{yr}$ and $2.8 \mathrm{hm}^{3} / \mathrm{yr}$ in the Benson and Narrows-Redington subareas, respectively. The outflows exceeded the inflows for both subareas for the period. The largest groundwater withdrawal in both subareas is for irrigation, although irrigation use has been steadily decreasing since 1973, when it peaked at $43.17 \mathrm{hm}^{3}$. In 2009, irrigation withdrawals had declined to $6.29 \mathrm{hm}^{3}$. The Benson subarea is the most populated part of the watershed and groundwater withdrawals could be one reason for the decline in water levels.

The use of EVI data to quantify and calculate the temporal and spatial distribution of ET has greatly improved the conceptual understanding of how ET impacts the hydrology of the watershed. The ET is calculated on a 16-day interval and $\mathrm{ET}_{\mathrm{gw}}$ is the largest groundwater outflow component for 2001-2009. The average annual groundwater withdrawals for ET $_{\mathrm{gw}}$ for 2001-2009 make up about 62 percent of the total groundwater withdrawals in the Benson subarea and 78 percent in the Narrows-Redington subarea.

Mountain-front recharge (MFR) and mountain-block recharge (MBR), and groundwater recharge by seepage from the San Pedro River are the primary sources of recharge in both subareas. In the Benson subarea, the average annual recharge from seepage is greater than recharge from MFR and MBR, while in the Narrows-Redington subarea, average annual MFR and MBR is greater than seepage. Long-term streamflow records from the Charleston and Redington gaging stations show declines in annual flow. Mean annual streamflow has also decreased at the Tombstone gaging station. As expected, the estimated annual seepage has decreased in both subareas but seepage has decreased the most during the wet months.

For most years in both subareas, seepage correlates with $\mathrm{ET}_{\mathrm{gw}}$. In both subareas, seepage and $\mathrm{ET}_{\mathrm{gw}}$ have been decreasing since 2006 and the highest rates for both $\mathrm{ET}_{\mathrm{gw}}$ and seepage occurred in 2001 and 2006. In the Benson subarea, $\mathrm{ET}_{\mathrm{gw}}$ stayed almost constant at least one year after years of high streamflow seepage: $\mathrm{ET}_{\mathrm{gw}}$ stayed almost constant in 2001 and 2002 and then again 2006 and 2007. In the NarrowsRedington subarea, $\mathrm{ET}_{\mathrm{gw}}$ remained almost constant for 2001 and 2002 but not for 2006 and 2007 despite high seepage in 2006. In 2001, there was seepage during wet, dry, and winter periods in the Narrows Redington and Benson subareas. In 2006, there was only seepage during the wet months. These results suggest that during years with high streamflow, enough water is held in storage in the local streambed aquifer to sustain the same levels of $\mathrm{ET}_{\mathrm{gw}}$ for up to one year.

Hydrochemical analysis of water samples from wells in the confined basin fill show relatively low levels of tritium and ${ }^{14} \mathrm{C}$, suggesting little evidence of modern recharge. In contrast, hydrochemical analysis of water samples from wells in the unconfined basin fill show evidence of modern recharge on the basis of tritium and ${ }^{14} \mathrm{C}$. There are some indications that mixing of water between the confined and unconfined aquifer occurs in wells near Saint David. Water-quality parameters have not changed significantly since 1996-1997. Fluoride levels are greater in the confined wells than in the unconfined wells in the middle San Pedro Watershed.

The groundwater-flow system in the middle San Pedro Watershed continues to respond to variations in climate and increased groundwater withdrawals. Understanding of the complex mechanisms controlling the movement of water from recharge areas to discharge areas is simplified with the groundwater budgets. The groundwater budgets can only be used to infer the relative magnitude of the components for previous time periods, however, and cannot be used to predict the local effects on the groundwater and surfacewater systems from withdrawals at specific wells. The data collected as part of this study can be used to develop a groundwater flow model that could be used to further understand the complex groundwater flow system.

The monitoring network established in the middle San Pedro Watershed is a collaborative effort of the Arizona Department of Water Resources and the U.S. Geological Survey. Continued collection of EVI, streamflow, waterlevel, and water-use data will continue to improve the understanding of hydrology of the middle San Pedro Watershed. 


\section{References Cited}

Adkins, C.B., 2009, Evidence for compartmentalization of aquifer systems - Solute and isotope geochemistry of groundwaters in the middle San Pedro Basin, Arizona: Tucson, University of Arizona, M.S. thesis, 72 p.

Anderson, T.W., Freethey, G.W., and Tucci, P., 1992, Geohydrology and water resources of alluvial basins in south-central Arizona and parts of adjacent states: U.S. Geological Survey Professional Paper 1406-B, 67 p.

Anderson, T.W., and Freethey, G.W., 1995, Simulation of ground-water flow in alluvial basins in southcentral Arizona and parts of adjacent States: U.S. Geological Survey Professional Paper 1406-D, 78 p.

Arizona Department of Administration Office of Employment and Population Statistics, 2011, Population estimates, accessed June 11, 2013, at http://www.workforce.az.gov/ population-estimates.aspx

Arizona Department of Commerce, 2010, accessed April 13, 2010 at http://www.azcommerce.com/econinfo/ demographics/Population+Estimates.html

Arizona Department of Water Resources, 1994, Arizona water resources assessment, volume II, hydrologic summary, August 1994: Arizona Department of Water Resources, 236 p.

Arizona Department of Water Resources, 2005, Groundwater resources of the Upper San Pedro Basin, Arizona, technical report to the Upper San Pedro Basin AMA review report: Arizona Department of Water Resources, $91 \mathrm{p}$.

Baillie, M.N., 2005, Quantifying baseflow inputs to the San Pedro River-A geochemical approach: Tucson, University of Arizona, M.S. thesis, $74 \mathrm{p}$.

Barrios, J., 2005, Growth crawls toward Benson: Arizona Daily Star, March 27, 2005, accessed July 25, 2005, at URL http://azstarnet.com/

Bennett, P.S., Kunzmann, M.R., and Graham, L.A., 2004, Descriptions of Arizona vegetation represented on the GAP vegetation map: U.S. Geological Survey Biological Resources Division, available at http://usgsbrd.srnr.arizona. edu/index.php?page $=$ datamenu\&lib $=0 \&$ sublib $=5$.

Blaney, H.F., and Criddle, W.D., 1964, Determining water requirements for settling water disputes: Natural Resources Journal, v. 4, p. 29-41.

Blasch, K.W., Hoffmann, J.P., Graser, L.F., Bryson, J.R., Flint, A.L., 2006, Hydrogeology of the upper and middle Verde River watersheds, central Arizona: U.S. Geological Survey Scientific Investigations Report 2005-5198, 102 p., 3 plates.
Brown, S.G., Davidson, E.S., Kister, L.R., and Thomsen, B.W., 1966, Water resources of Fort Huachuca Military Reservation, southeastern Arizona: U.S. Geological Survey Water Supply Paper 1819-D, 57 p.

Bryan, K., Smith, E.P.G., and Waring, G.A., 1934, Groundwater supplies and irrigation in San Pedro Valley, Arizona: U.S. Geological Suvey Open-File Report 67-31, 170 p.

Bureau of Reclamation, 1992, Plan of study and methods manual for Colorado River system consumptive uses and losses report 1985-1990: Bureau of Reclamation, Appendix A, $23 \mathrm{p}$.

Burtell, R.T., 1989, Geochemistry and occurrence of ground water in the Allen Flat Basin, Arizona: Tucson, University of Arizona, M.S. thesis, $164 \mathrm{p}$.

Cayan, D.R., and Webb, R.H., 1992, El Nino/Southern Oscillation and streamflow in the western United States, in Diaz, H.F., and Markgraf, V., eds., El Nino: historical and paleoclimatic aspects of the southern oscillation: Cambridge, Cambridge University Press, p. 29-68.

Cochise College Center for Economic Research, 2007, 2006-2007 Benson Prospectus, An Economic Overview of Benson, Arizona and the San Pedro Presented by the Cochise College Center for Economic Research, 65 p., accessed February 23, 2011 at http://www.cochise. edu/deptsdirs/organizations/cer/documents/luncheon publications/2007_Benson_Prospectus.pdf.

Cochise College Center for Economic Research, 2009, Benson Economic Outlook 2009, An Economic Overview of Benson, Arizona and the San Pedro Presented by the Cochise College Center for Economic Research, 67 p., accessed January 14, 2011 at http://www.cochise. edu/deptsdirs/organizations/cer/documents/luncheon publications/2009_Benson_Economic_Outlook.pdf.

Coes, A.L., Gellenbeck, D.J., and Towne, D.C., 1999, Groundwater quality in the Sierra Vista subbasin, Arizona, 1996-97: U.S. Geological Survey Water-Resources Investigations Report 99-4056, 50 p.

Coes, A.L., and Pool, D.R., 2005, Ephemeral-stream channel and basin-floor infiltration and recharge in the Sierra Vista subwatershed of the Upper San Pedro Basin, southeastern Arizona: U.S. Geological Survey Open-File Report 20051023, $67 \mathrm{p}$.

Coes, A.L., and Pool, D.R., 2007, Ephemeral-stream channel and basin-floor infiltration and recharge in the Sierra Vista subwatershed of the Upper San Pedro Basin, southeastern Arizona, in Stonestrom, D.A., Constantz, J., Ferre, T.P.A., and Leake, S.A., eds., Ground-water recharge in the arid and semiarid southwestern United States: U.S. Geological Survey Professional Paper 1703-J, p. 253-311. 
Cook, J.P., Youberg, A., Pearthree, P.A., Onken, J.A., MacFarlane, B.J., Haddad, D.E., Bigio, E.R., and Kowler, A.L., 2009, Mapping of Holocene river alluvium along the San Pedro River, Aravaipa Creek, and Babocomari River, southeastern Arizona: Arizona Geological Survey Digital Map DM-RM-01, 76 p.

Clark, I., and Fritz, P., 1997, Environmental isotopes in hydrogeology: New York, Lewis Publishers, 352 p.

Cleveland, W.S., 1979, Robust locally weighted regression and smoothing scatterplots: Journal American Statistical Association, v. 74, p. 829-836.

Corell, S.W., Corkhill, F., Lovvik, D., and Putnam, F., 1996, A groundwater flow model of the Sierra Vista Subwatershed of the Upper San Pedro Basin-southeastern Arizona: Arizona Department of Water Resources Model Report 10, $107 \mathrm{p}$.

Dettinger, M.D., 2005, Changes in streamflow timing in the Western United States in recent decades: U.S. Geological Survey Fact Sheet 2005-3018, 4 p.

Dickinson, J.E., Hanson, R.T., Ferré, T.P.A., and Leake, S.A., 2004, Inferring time-varying recharge from inverse analysis of long-term water levels: Water Resources Research, v. 40, no. 7 , p. 1-15.

Dickinson, J.E., Kennedy, J.R., Pool, D.R., Cordova, J.T., Parker, J.T.C., Macy, J.P., and Thomas, B.E., 2010a, Hydrogeologic framework of the middle San Pedro Watershed, southeastern Arizona: U.S. Geological Survey Scientific Investigations Report 2010-5126, 36 p.

Dickinson, J.E., Pool, D.R., Groom, R.W., and Davis, L.J., 2010b, Inference of lithologic distributions in an alluvial aquifer using airborne transient electromagnetic surveys: Geophysics, v. 75, no. 4, p. WA149-WA161.

Dickinson, W.R., 1991, Tectonic setting of faulted Tertiary strata associated with the Catalina core complex in southern Arizona: Geological Society of America Special Paper 264, $106 \mathrm{p}$.

Dickinson, W.R., 2003, Depositional facies of the Quibruis Formation, basin fill of the San Pedro trough, southeastern Arizona Basin and Range Province, in Raynolds, R.G., and Flores, R.M., eds., Cenozoic systems of the Rocky Mountain region: Denver, Colorado, Society for Sedimentary Geology, p. 157-181.

Drewes, H., 1974, Geologic map and sections of the Happy Valley quadrangle, Cochise County, Arizona: U.S. Geological Survey Miscellaneous Investigations Series Map I-832, 1 sheet, scale 1:48,000.

Drewes, H.D., 1981, Tectonics of southeastern Arizona: U.S. Geological Survey Professional Paper 1144, 96 p.
Fenneman, N.M., 1931, Physiography of western United States (1st ed.): New York, McGraw-Hill, 534 p.

Flint, L.E., and Flint, A.L., 2007, Regional analysis of groundwater recharge in Stonestrom, D.A., Constantz, J., Ferre, T.P.A., and Leake, S.A., eds., Ground-water recharge in the arid and semiarid southwestern United States: U.S. Geological Survey Professional Paper 1703-B, p. 29-60, available at http://pubs.usgs.gov/pp/pp1703/b/.

Freethey, G.W., 1982, Hydrologic analysis of the Upper San Pedro Basin from the Mexico-United States international boundary to Fairbank, Arizona: U.S. Geological Survey Open-File Report 82-752, 64 p.

Freethey, G.W., and Anderson, T.W., 1986, Predevelopment hydrologic conditions in the alluvial basins of Arizona and adjacent parts of California and New Mexico: U.S. Geological Survey, scale 1:500,000.

Garner, B.D., and Truini, Margot, 2011, Groundwater budgets for Detrital, Hualapai, and Sacramento Valleys, Mohave County, Arizona, 2007-08: U.S. Geological Survey Scientific Investigations Report 2011-5159, 34 p., available at http:// pubs.usgs.gov/sir/2011/5159/.

Glenn, E.P., Huete, A.R., Nagler,P.L., Hirschboek, K., Brown, P. 2007, Integrating remote sensing and ground methods to estimate evapotranspiration: Critical Reviews in Plant Sciences, v. 26, p. 139-168.

Glenn, E., Nagler, P., Huete, A., 2010, Vegetation index methods for estimating evapotranspiration by remote sensing: Surveys in Geophysics, v. 31, p. 531-555.

Goode, T.C., and Maddock, T.I., 2000, Simulation of groundwater conditions in the Upper San Pedro Basin for the evaluation of alternative futures: University of Arizona, Department of Hydrology and Water Resources, catalog no. 2000-030, 113 p.

Goodrich, D.C., Scott, R.L., and others, 2000, Seasonal estimates of riparian evapotranspiration using remote and in-situ measurements: Agricultural and Forest Meteorology, v. 105, p. 281-309

Groeneveld, D.P., Baugh, W.M., Sanderson, J.S., Cooper, D.J., 2007, Annual groundwater evapotranspiration mapped from single satellite scenes: Journal of Hydrology, v. 344, p. 146156.

Gu, A., 2005, Stable isotope geochemistry of sulfate in groundwater of Southern Arizona - Implication for groundwater flow, sulfate sources, and environmental significance: Tucson, University of Arizona, Ph.D. dissertation, 256 p.

Halvorson W.L., Thomas, K.A, Graham, L.A., Kunzmann, M.R, Bennett, P.S., Van Riper, C., 2001, Arizona GAP Report, in Drost, C., and Gebow, B.S., eds., Final report to the national GAP office, USFWS, NBS, and USGS Gap Analysis Program. 
Hereford, R., 1993, Entrenchment and widening of the Upper San Pedro River, Arizona: Geological Society of America Special Paper 282, 46 p.

Healy, R.W., Winter, T.C., LaBaugh, J.W., and Franke, O.L., 2007, Water budgets-Foundations for effective waterresources and environmental management: U.S. Geological Survey Circular 1308, 90 p.

Hidalgo, H.G., Das, T., Dettinger, M.D., Cayan, D.R., Pierce, D.W., Barnett, T.P., Bala, G., Mirin, A., Wood, A.W., Bonfils, C., Santer, B.D., and Nozawa, T., 2009, Detection and attribution of streamflow timing changes to climate change in the western United States: Journal of Climate, v. 22, no. 13 , p. 3838-3855.

Hollett, K.J., Danskin, W.R., McCaffrey, W.F., and Walti, C.L., 1991, Geology and water resources of Owens Valley, California: U.S. Geological Survey Water Supply Paper 2370-B, 77 p.

Hopkins, C., McIntosh, J., Eastoe, C., Dickinson, J.E., and Meixner, T., 2014, Evaluation of the importance of clay confining units on groundwater flow in alluvial basins using solute and isotope tracers: the case of Middle San Pedro Basin in southeastern Arizona (USA): Hydrogeology Journal, p. 1-21.

Huete, A.R., Didan, K., Miura, T., Rodriguez, E.P., Gao, X., and Ferreira, L.G., 2002, Overview of the radiometric and biophysical performance of the MODIS vegetation indices: Remote Sensing of the Environment, v. 83, p. 195-213.

Jahnke, P., 1994, Modeling of groundwater flow and surface/ groundwater interaction for the San Pedro River Basin from Fairbank to Redington, Arizona: Tucson, University of Arizona, M.S. thesis.

Kalma, J.D., McVicar, T.R., McCabe, M.F., 2008, Estimating land surface evaporation-A review of methods using remotely sensed surface temperature data: Surveys in Geophysics, v. 29, p. 421-469.

Kennedy, J.R., and Gungle, B., 2010, Quantity and sources of base flow in the San Pedro River near Tombstone, Arizona: U.S. Geological Survey Scientific Investigations Report 2010-5200, 43 p.

Kennedy, J.R., Winester, D., 2011, Gravity data from the San Pedro River Basin, Cochise County, Arizona: U.S. Geological Survey Open-File Report 2011-1287, 11 p. and data files, available at http://pubs.usgs.gov/of/2011/1287/.

Lee, W.T., 1905, Notes on the underground water of the San Pedro Valley, Arizona, in Third annual report of the Reclamation Service, 1903-04: U.S. 58th Congress, 3d Sess., H. Doc. 28, 2d ed., p. 165-170.
Leenhouts, J.M., Stromberg, J.C., and Scott, R.L., 2006, Hydrologic requirements of and consumptive groundwater use by riparian vegetation along the San Pedro River, Arizona: U.S. Geological Survey Scientific Investigations Report 2005-5163, 154 p.

Maddock III, T., and Vionnet, L.B., 1998, Groundwater capture processes under a seasonal variation in natural recharge and discharge: Hydrogeology Journal, v. 6, no. 1, p. 24-32.

Mayes, H.M., and Arizona Crop and Livestock Reporting Service, 1974, Cropland atlas of Arizona: Tucson, University of Arizona College of Agriculture, 68 p. McCabe, G.J., and Dettinger, M.D., 1999, Decadal variations in the strength of ENSO teleconnections with precipitation in the western United States: International Journal of Climatology, v. 19, no. 13, p. 1399-1410.

Nagler, P., Cleverly, J., Glenn, E., Lampkin, D., Huete, A., and Wan, Z., 2005a, Predicting riparian evapotranspiration from MODIS vegetation indices and meteorological data: Remote Sensing of Environment, v. 94, p. 17-30.

Nagler, P.L., Scott, R.L., Westenberg, C., Cleverly, J.R., Glenn, E.P., and Huete, A.R., 2005b, Evapotranspiration on western U.S. rivers estimated using the Enhanced Vegetation Index from MODIS and data from eddy covariance and Bowen ratio flux towers: Remote Sensing of Environment, v. 97, p. 337-351.

Pool, D.R., 2005, Variations in climate and ephemeral channel recharge in southeastern Arizona, United States: Water Resources Research, v. 41, doi10.1029/2004WR003255.

Pool, D.R., and Coes, A.L., 1999, Hydrogeologic investigations of the Sierra Vista subwatershed of the upper San Pedro Basin, Cochise County, southeast Arizona: U.S. Geological Survey Water-Resources Investigations Report 99-4197, 41 p.

Pool, D.R., and Dickinson, J.E., 2007, Ground-water flow model of the Sierra Vista subwatershed and Sonoran portions of the upper San Pedro basin, southeastern Arizona, United States, and northern Sonora, Mexico: U.S. Geological Survey Scientific Investigations Report 20065228, 48 p.

Pool, D.R., Blasch, K.W., Callegary, J.B., Leake, S.A., and Graser, L.F., 2011, Regional groundwater-flow model of the Redwall-Muav, Coconino, and alluvial basin aquifer systems of northern and central Arizona: U.S. Geological Survey Scientific Investigations Report 2010-5180, 101 p.

PRISM, 2010, Precipitation data from PRISM Group at Oregon State University: accessed August, 2010, at http:// www.prism.oregonstate.edu/. 
Putman, F., Mitchell, K., and Bushner, G., 1988, Water Resources of the Upper San Pedro Basin, Arizona: Arizona Department of Water Resources, Hydrology Division, 158 p.

Robertson, F.N., 1991, Geochemistry of ground water in alluvial basins of Arizona and adjacent parts of Nevada, New Mexico, and California: Washington: U.S. Geological Survey Professional Paper 1406-C, 102 p., available at http://pubs.er.usgs.gov/publication/pp1406C.

Roeske, R.H., and Werrell, W.L., 1973, Hydrologic conditions in the San Pedro River valley, Arizona, 1971: Arizona Water Commission Bulletin 4, 76 p.

Rojo, H.A., Bredehoft, J., Lacwell, R., Price, J., Stromberg, J., and Thomas, G.A., 1999, Sustaining and enhancing riparian migratory bird habitat on the upper San Pedro RiverFinal draft from the San Pedro expert study team, prepared for the Secretariat of the Commission for Environmental Cooperation, March 1999, 123 p.

Rovey, C., 1989. Hydrologic investigation of the Upper San Pedro Basin, Southeastern Arizona, preliminary report.

Scarborough, R.B., and Peirce, H.W., 1978, Late Cenozoic basins of Arizona, in Callender, J.F., Wilt, J.C., and Clemons, R.E., eds., Land of Cochise, Southeastern Arizona: New Mexico Geological Society Guidebook, 29th field conference, p. 253-259.

Scott, R.L., 2010, Using watershed water balance to evaluate the accuracy of eddy covariance evaporation measurements for three semiarid ecosystems: Agricultural and Forest Meteorology v. 150, p. 219-225.

Scott, R.L., Williams, D.G., Goodrich, D.G., Cable, W.L., Levick, L., McGuire, R., Gazal, R.M., Yepez, E.A., Ellsworth, P., Huxman, T.E., 2006, Determining the riparian groundwater use within the San Pedro Riparian National Conservation Area and the Sierra Vista Subwatershed, Arizona, chap. D of Leenhouts, J.M., Stromberg, J.C., Scott, R.L., eds., Hydrologic requirements of and consumptive ground-water use by riparian vegetation along the San Pedro River, Arizona: U.S. Geological Survey Scientific Investigations Report 2005-5163, p. 107-152.

Scott, R.L., Cable, W.L., Huxman, T.E., Nagler P.L., Hernandez, M., Goodrich., D.C., 2008, Multiyear riparian evapotranspiration and groundwater use for a semiarid watershed, Journal of Arid Environments, v. 72, p. 1232-1246.

Shafiqullah, M., Damon, P.E., Lynch, D.J., Reynolds, S.J., Rehrig, W.A., and Raymond, R.H., 1980, K-Ar geochronology and geologic history of southwestern Arizona and adjacent areas, in Jenny, J.P., and Stone, C., eds., Studies in western Arizona: Tucson, Arizona Geological Society Digest v. 12, p. 201-260.
Sharma, V., MacNish, R.D., and Maddock, T., III, 1997, Analysis of hydrologic data collected by the U.S. Bureau of Land Management 1987-1995 and recommendations for future monitoring programs: Tucson, University of Arizona, Arizona Research Laboratory for Riparian Studies, Department of Hydrology and Water Resources, HWR no. 97-060, $61 \mathrm{p}$.

Tadayon, S., 2005, Water withdrawals for irrigation, municipal, mining, thermoelectric power, and drainage uses in Arizona outside of active management areas, 1991-2000: U.S. Geological Survey Scientific Investigations Report 2004-5293, 38 p.

Telford, W.M., Geldart, L.P., Sheriff, R.E., 1990, Applied Geophysics, 2d ed.: Cambridge University Press, 792 p.

Thomas, B.E., and Pool, D.R., 2006, Trends in streamflow of the San Pedro River, Southeastern Arizona, and regional trends in precipitation and streamflow in southeastern Arizona and southwestern New Mexico: U.S. Geological Survey Professional Paper 1712, 79 p., available at http:// pubs.usgs.gov/pp/pp1712/.

Tillman, F.D, Cordova, J.T., Leake, S.A., Thomas, B.E., and Callegary, J.B., 2011, Water availability and use pilot-Methods development for a regional assessment of groundwater availability, southwest alluvial basins, Arizona: U.S. Geological Survey Scientific Investigations Report 2011-5071, 118 p. and online appendix, available at http://pubs.usgs.gov/sir/2011/5071/.

Towne, D.C., 2002, Ambient groundwater quality of the Lower San Pedro Basin-A 2000 baseline study: Arizona Department of Environmental Quality Open-File Report 2002-01, 39 p.

U.S. Census Bureau, 2006, Annual estimates of the population for incorporated places in Arizona: U.S. Census Bureau, accessed January 6, 2006, at http://www.census.gov/prod/ www/abs/decennial/index.htm.

U.S. Department of the Interior, 2011, Water management of the regional aquifer in the Sierra Vista subwatershed, Arizona-2009 report to Congress: Sierra Vista, Ariz., Upper San Pedro Partnership, 82 p., available at http:// az.water.usgs.gov/pubs/2009Section321Report.pdf, http:// az.water.usgs.gov/pubs/2009Section321Report_AppendixA. pdf, http://az.water.usgs.gov/pubs/2009Section321Report AppendixesB-C-D-E-F.pdf.

U.S. Environmental Protection Agency, 2007, Drinking water standards and health advisories table: U.S. Environmental Protection Agency, 30 p., available at http://water.epa.gov/ drink/standards/hascience.cfm. 
U.S. Geological Survey, variously dated, National field manual for the collection of water-quality data: U.S. Geological Survey Techniques of Water-Resources Investigations, book 9, chaps. A1-A9, available at http:// pubs.water.usgs.gov/twri9A.

Vionnet, L.B., and Maddock,T., III, 1992, Modeling of ground-water flow and surface water/groundwater interactions in the San Pedro River Basin-Part ICananea, Mexico to Fairbank, Arizona: Tucson, University of Arizona, Department of Hydrology and Water Resources, HWR no. 92-010, 96 p.

Webb, R.H., Betancourt, J.L., 1992, Climatic variability and flood frequency of the Santa Cruz River, Pima County, Arizona: U.S. Geological Survey Water-Supply Paper 2379, 40 p., available at http://pubs.er.usgs.gov/ publication/wsp2379.
Webb, R.H., McCabe, G.J., Hereford, R., and Wilkowske, C., 2004, Climatic fluctuations, drought, and flow of the Colorado River: U.S. Geological Survey Fact Sheet 2004-3062, 4 p., available at http://pubs.usgs.gov/fs/2004/3062/.

Whittier, J.D., and Maddock, T., III, 2004, A Lower San Pedro River Basin Groundwater Flow Model: Tucson, Department of Hydrology and Water Resources and University of Arizona Research Laboratory for Riparian Studies, HWR no. 04-05, 118 p.

Wynn, J.C., 2006, Mapping ground water in three dimensionsAn analysis of airborne geophysical surveys of the Upper San Pedro River Basin, Cochise County, Southeastern Arizona: U.S. Geological Survey Professional Paper 1674, 33 p.

Zhu, C., 2000, Estimate of recharge from radiocarbon dating of groundwater and numerical flow and transport modeling: Water Resources Research, v. 36, no. 9, p. 2607-2620. 
Appendix 
Table A1. Water-quality data for precipitation, surface water, and groundwater in the middle San Pedro watershed collected from 2007 to February 2009.

[all major and trace elements are dissolved. ${ }^{\circ} \mathrm{C}$, degrees Celsius; $\mu \mathrm{S} / \mathrm{cm}$, microsiemens per centimeter; $\mathrm{mg} / \mathrm{L}$, milligrams per liter; $\mathrm{N}$, nitrogen; P, phosphorus; $\%$, per mil; TU, tritium units; pmc, percent modern carbon]

\begin{tabular}{|c|c|c|c|c|c|c|c|c|c|c|c|c|c|c|c|c|c|}
\hline \multirow{2}{*}{ 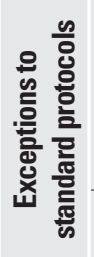 } & \multicolumn{2}{|l|}{ Station } & \multirow{2}{*}{$\begin{array}{c}\text { Sample } \\
\text { date }\end{array}$} & \multirow{2}{*}{ 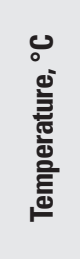 } & \multicolumn{2}{|c|}{$\begin{array}{c}\text { Specific } \\
\text { conductance, } \\
\mu S / c m\end{array}$} & \multicolumn{2}{|c|}{$\mathrm{pH}$} & 言 & \multirow[t]{2}{*}{ 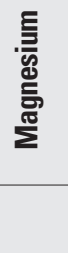 } & \multirow[t]{2}{*}{ 吾 } & \multirow[t]{2}{*}{$\begin{array}{l}\text { 言 } \\
\text { 总 } \\
\text { 흄 }\end{array}$} & \multirow{2}{*}{ 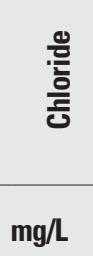 } & \multirow[t]{2}{*}{ 荧 } & \multirow[t]{2}{*}{$\begin{array}{l}\text { 薦 } \\
\text { क }\end{array}$} & \multirow[t]{2}{*}{$\begin{array}{l}\stackrel{0}{\frac{0}{2}} \\
\text { 흔 }\end{array}$} & \multirow[t]{2}{*}{ 흘 } \\
\hline & Number & Name & & & Field & Lab & Field & Lab & & & & & & & & & \\
\hline 5,6 & 315712110205401 & $(\mathrm{BF}, \mathrm{B}) 1 \mathrm{~A}$ & $9 / 15 / 2007$ & 25.3 & 120 & & 7.4 & & 43.7 & 12.4 & 16.8 & 2.2 & 5.0 & 3.11 & 3.9 & 2.3 & 0.08 \\
\hline 5,6 & 315655110205201 & $(\mathrm{BF}, \mathrm{B}) 2$ & $9 / 15 / 2007$ & 25.5 & 400 & & 7.3 & & 45.1 & 11.1 & 17.3 & 2.3 & 7.3 & 3.67 & 4.1 & 2.4 & 0.09 \\
\hline 5,6 & 315216110122801 & A1 & $9 / 15 / 2007$ & 24.8 & 330 & & 7.6 & & 57.6 & 6.4 & 25.2 & 1.9 & 4.6 & 1.61 & 44.2 & 6.0 & 0.08 \\
\hline 5 & 315444110135001 & $\mathrm{~A} 2$ & $6 / 13 / 2008$ & 19.7 & 677 & & 7.0 & & 135 & 25.0 & 91.2 & 0.68 & 13.6 & 7.81 & 131 & 1.5 & 0.20 \\
\hline 5 & 315454110135101 & A3 & $6 / 13 / 2008$ & 19.4 & 764 & 1040 & 7.0 & 7.2 & 123 & 23.7 & 85.2 & 0.74 & 14.5 & 5.93 & 132 & 1.5 & 0.14 \\
\hline 5 & 315640110160901 & A4 & $5 / 29 / 2008$ & 20.6 & 923 & & 7.2 & & 108 & 19.5 & 114 & 3.2 & 19.1 & 30.6 & 206 & 2.0 & 0.41 \\
\hline $2,3,5$ & 315810110162401 & A5 & $6 / 18 / 2008$ & 20.5 & 1756 & & 7.1 & & 93.6 & 47.8 & 387.9 & 1.6 & 39.5 & 31.7 & 637 & 2.1 & 0.61 \\
\hline 5,6 & 321542110205301 & A6 & $2 / 15 / 2009$ & 19.4 & 866 & 894 & 7.8 & 8.0 & 72.2 & 17.9 & 101 & 6.8 & 21.8 & 1.13 & 172 & 1.4 & 0.19 \\
\hline 5,6 & 321727110230201 & A7 & $2 / 15 / 2009$ & 22.3 & 548 & 567 & 7.6 & 7.6 & 77.8 & 11.1 & 23.8 & 4.1 & 3.9 & 4.25 & 25.1 & 0.49 & 0.05 \\
\hline $3,5,6$ & 322658110292101 & A8 & $2 / 15 / 2009$ & 20.6 & 511 & 443 & 7.8 & 7.7 & 40.1 & 7.0 & 37.2 & 3.9 & 10.5 & 3.92 & 30.8 & 0.87 & 0.08 \\
\hline 1,5 & 314514110032601 & $\mathrm{~B} 2$ & $1 / 13 / 2009$ & 9.9 & 329 & & 7.9 & & 33.3 & 17.4 & 14.2 & 3.5 & 5.9 & 6.92 & 12.5 & 0.71 & 0.09 \\
\hline $2,5,6$ & 314958110211501 & B3 & $9 / 15 / 2007$ & 22.4 & 519 & & 7.2 & & 63.9 & 13.2 & 17.1 & 1.3 & 11.2 & 3.55 & 24.4 & 2.0 & 0.11 \\
\hline 3,5 & 315218110212401 & B4 & $4 / 14 / 2008$ & 22.4 & 476 & & 7.3 & & 35.5 & 8.7 & 70.7 & 1.5 & 23.9 & 2.43 & 17.0 & 3.8 & 0.32 \\
\hline 1 & 315309110214601 & B5 & $4 / 14 / 2008$ & 22.7 & 545 & & 7.4 & & 61.2 & 17.6 & 46.1 & 1.0 & 54.2 & 17.8 & 12.6 & 2.8 & 0.55 \\
\hline 5,6 & 315528110222001 & B7 & $11 / 3 / 2007$ & 24.1 & 304 & & 8.3 & & 45.3 & 9.3 & 9.9 & 1.3 & 9.1 & 6.71 & 7.2 & 0.72 & 0.14 \\
\hline 1,5 & 315544110252301 & B8 & $4 / 14 / 2008$ & 23.0 & 652 & & 7.3 & & 70.2 & 27.5 & 26.2 & 1.9 & 31.8 & 15.1 & 14.2 & 1.4 & 0.26 \\
\hline 5 & 315547110025301 & B9 & $3 / 16 / 2008$ & 20.6 & 628 & & 8.2 & & 21.4 & 0.51 & 104 & 1.4 & 17.7 & 1.11 & 116 & 7.7 & 0.16 \\
\hline 5 & 315551110250101 & $\mathrm{~B} 10$ & $5 / 14 / 2008$ & 21.3 & 416 & 398 & 7.5 & 7.6 & 60.1 & 7.6 & 11.1 & 1.4 & 14.6 & 8.75 & 11.6 & 0.55 & 0.12 \\
\hline 3 & 315655110024301 & B11 & $6 / 20 / 2008$ & 20.0 & 591 & & 7.4 & & 110 & 20.8 & 12.0 & 2.8 & 11.2 & 7.71 & 108 & 0.76 & 0.23 \\
\hline 5,6 & 315656110195301 & B12 & $9 / 15 / 2007$ & 26.4 & 180 & & 7.3 & & 36.1 & 15.2 & 19.7 & 1.9 & 5.0 & 2.52 & 9.7 & 1.0 & 0.08 \\
\hline 5 & 315719110265701 & B13 & $5 / 30 / 2008$ & 22.8 & 406 & & 6.7 & & 57.1 & 10.7 & 25.3 & 1.7 & 12.0 & 11.1 & 8.7 & 1.1 & 0.17 \\
\hline 5 & 315736110250301 & B14 & $2 / 10 / 2008$ & 23.8 & 729 & & 7.8 & & 22.4 & 18.2 & 82.9 & 3.0 & 6.7 & 0.08 & 26.6 & 1.5 & 0.09 \\
\hline \multirow[t]{2}{*}{$3,4,5$} & 315738110020501 & B15 & $6 / 20 / 2008$ & 18.8 & 236 & & 7.0 & & 145 & 29.0 & 19.1 & 1.5 & 12.5 & 3.39 & 151 & 0.70 & 0.25 \\
\hline & 315946110211701 & B16 & $3 / 17 / 2008$ & 22.1 & 211 & & 7.6 & & 40.0 & 11.9 & 22.6 & 1.4 & 10.0 & 6.56 & 7.9 & 1.0 & 0.17 \\
\hline 4,5 & 320148110090701 & B17 & $6 / 16 / 2008$ & 22.7 & 376 & & 7.4 & & 75.8 & 14.0 & 28.8 & 2.1 & 10.2 & 6.31 & 29.2 & 0.86 & 0.17 \\
\hline 5,6 & 320200110022101 & B18 & $12 / 13 / 2008$ & 26.0 & 436 & & 7.7 & & 51.4 & 19.3 & 10.9 & 2.0 & 9.3 & 6.25 & 22.0 & 1.0 & 0.13 \\
\hline \multirow[t]{3}{*}{$2,5,6$} & 320209110282401 & B19 & $11 / 3 / 2007$ & 20.7 & 222 & & 8.0 & & 39.5 & 3.9 & 9.2 & 1.3 & 6.0 & 10.1 & 9.3 & 1.0 & 0.09 \\
\hline & 320316110223301 & $\mathrm{~B} 20$ & $2 / 2 / 2008$ & & & & 7.8 & & 38.7 & 6.6 & 14.4 & 1.9 & 10.2 & 7.38 & 5.6 & 0.56 & 0.14 \\
\hline & 320327110255901 & B21 & $1 / 15 / 2008$ & 7.9 & 221 & & 7.2 & & 19.8 & 4.4 & 23.5 & 1.4 & 9.0 & 1.51 & 35.1 & 0.48 & 0.12 \\
\hline $1,5,6$ & 320422110265601 & B22 & $11 / 3 / 2007$ & 20.5 & 190 & & 7.8 & & 13.9 & 3.4 & 29.9 & 1.3 & 10.0 & 2.46 & 5.7 & 1.1 & 0.11 \\
\hline 5 & 314245110204901 & BF2 & $11 / 2 / 2008$ & 23.9 & 1100 & & 7.3 & & 242 & 79.6 & 7.9 & 2.8 & 29.6 & 11.9 & 645 & 2.1 & 0.01 \\
\hline 5 & 314300110203001 & BF3 & $11 / 2 / 2008$ & 23.5 & 1080 & & 7.5 & & 256 & 81.7 & 7.9 & 3.0 & 29.8 & 11.7 & 711 & 2.1 & 0.01 \\
\hline 5 & 314318110132701 & $\mathrm{BF} 4$ & $11 / 22 / 2008$ & 21.0 & 323 & & 8.7 & & 1.8 & 0.12 & 64.6 & 0.46 & 6.4 & 1.75 & 22.8 & 0.58 & 0.07 \\
\hline 3,5 & 315305110053101 & BF6 & $4 / 26 / 2008$ & 22.4 & 326 & & 7.6 & & 51.5 & 4.2 & 12.3 & 1.5 & 5.5 & 4.15 & 4.9 & 1.5 & 0.13 \\
\hline 4,5 & 315315110060501 & BF7 & $4 / 26 / 2008$ & 24.0 & 321 & & 7.9 & & 55.6 & 4.5 & 11.9 & 1.2 & 8.9 & 3.95 & 5.7 & 1.1 & 0.14 \\
\hline
\end{tabular}


Table A1. Water-quality data for precipitation, surface water, and groundwater in the middle San Pedro watershed collected from 2007 to February 2009.

[all major and trace elements are dissolved. ${ }^{\circ} \mathrm{C}$, degrees Celsius; $\mu \mathrm{S} / \mathrm{cm}$, microsiemens per centimeter; $\mathrm{mg} / \mathrm{L}$, milligrams per liter; $\mathrm{N}$, nitrogen; $\mathrm{P}$, phosphorus; $\%$, per mil; TU, tritium units; pmc, percent modern carbon]

\begin{tabular}{|c|c|c|c|c|c|c|c|c|c|c|c|c|c|c|c|c|}
\hline \multirow{2}{*}{$\begin{array}{c}\text { Station } \\
\text { name }\end{array}$} & \multirow{2}{*}{\multicolumn{2}{|c|}{$\begin{array}{c}\text { 产 } \\
\frac{\text { 离 }}{\text { 产 }} \\
\text { as } \mathrm{CaCO}_{3}, \mathrm{mg} / \mathrm{L}\end{array}$}} & \multirow[t]{2}{*}{ 豆 } & \multirow[t]{2}{*}{ 慰 } & \multirow{2}{*}{$\begin{array}{c}\text { 흔 } \\
\text { ๓ } \\
\mu g / L\end{array}$} & \multirow[t]{2}{*}{ 흐 } & \multirow[t]{2}{*}{ 豆 } & \multirow{2}{*}{ 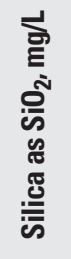 } & \multirow{2}{*}{$\begin{array}{l}\text { 흘 } \\
\text { E् } \\
\text { 竞 } \\
\text { 心 }\end{array}$} & $\delta^{2} \mathrm{H}$ & $\delta^{18} 0$ & \multirow{2}{*}{ 兰 } & \multirow{2}{*}{$\begin{array}{l}\text { ? } \\
\text { E } \\
\text { 豆 }\end{array}$} & \multirow{2}{*}{ 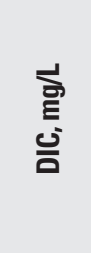 } & \multirow{2}{*}{\multicolumn{2}{|c|}{ 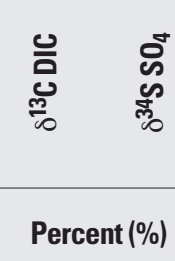 }} \\
\hline & & & & & & & & & & \multicolumn{2}{|c|}{$\mathrm{H}_{2} \mathrm{O}(\%)$} & & & & & \\
\hline$(\mathrm{BF}, \mathrm{B}) 1 \mathrm{~A}$ & 168 & & & & & & & 17.0 & 348 & -54 & -7.7 & & $<0.3$ & 46.7 & -6.2 & 11.0 \\
\hline$(\mathrm{BF}, \mathrm{B}) 2$ & 171 & & & & & & & 16.7 & 232 & -57 & -8.2 & & $<0.4$ & 41.8 & -6.6 & 8.7 \\
\hline $\mathrm{A} 1$ & 160 & & & & & & & 18.0 & 1016 & -51 & -7.4 & & $<0.6$ & 38.3 & -10.1 & 5.5 \\
\hline A2 & 434 & & & & & & & 27.9 & 1746 & -51 & -7.0 & & 2.7 & 108.6 & -7.9 & 3.3 \\
\hline A3 & 424 & 410 & E 0.8 & & 175 & E 5 & 54 & 50.1 & 1870 & -52 & -7.0 & & 2.5 & 108.7 & -10.3 & 2.6 \\
\hline A4 & 300 & & & & & & & 14.5 & 2570 & -52 & -7.2 & & 2.6 & 72.7 & -9.1 & 5.4 \\
\hline A5 & 501 & & & & & & & 18.1 & 3463 & -50 & -6.8 & & 2.9 & 119.5 & -9.1 & 7.0 \\
\hline A6 & 287 & 260 & & & 133 & 322 & 99 & 22.8 & 1210 & -58 & -8.7 & & 3.3 & 63.0 & -10.3 & 6.6 \\
\hline A7 & 273 & 240 & & & 48 & $<4$ & 25 & 22.7 & 570 & -62 & -9.2 & & & 68.9 & -11.8 & 6.0 \\
\hline A8 & 168 & 130 & & & 52 & 160 & 48 & 17.9 & 354 & -53 & -7.9 & & & 40.2 & -9.6 & 9.3 \\
\hline B2 & 151 & & & & & & & 19.4 & 389 & & & 38.7 & & 38.5 & -5.5 & 5.6 \\
\hline B3 & 194 & & & & & & & 11.7 & 138 & -66 & -9.4 & & 2.4 & 44.5 & -8.0 & 3.8 \\
\hline B4 & 219 & & & & & & & & 460 & -71 & -10.0 & & 0.9 & 49.9 & -9.7 & 11.7 \\
\hline B5 & 202 & & & & & & & & 313 & -63 & -8.8 & 58.7 & 0.5 & 46.8 & -8.9 & 7.6 \\
\hline B7 & 140 & & & & & & & 10.6 & 142 & -60 & -8.7 & 38.7 & $<0.6$ & 32.2 & -10.0 & 9.0 \\
\hline B8 & 248 & & & & & & & & 462 & -63 & -9.0 & 56.1 & 1.3 & & -9.3 & 6.9 \\
\hline B9 & 121 & & & & & & & & 454 & -75 & -10.6 & 23.64 & $<0.5$ & 28.4 & -7.3 & 11.2 \\
\hline $\mathrm{B} 10$ & 171 & 180 & $<1.6$ & 63.5 & 33 & E 4 & 12 & 22.9 & 156 & -63 & -9.0 & & 2.7 & 40.3 & -8.2 & 5.4 \\
\hline B11 & 240 & & & & & & & 16.3 & 450 & -63 & -8.8 & & & 55.4 & -7.6 & 6.1 \\
\hline B12 & 188 & & & & & & & 16.1 & 535 & -58 & -8.7 & & $<0.4$ & 42.5 & -6.1 & 10.5 \\
\hline B13 & 180 & & & & & & & 13.7 & 296 & -59 & -8.2 & & 1.3 & 47.0 & -6.9 & 10.5 \\
\hline B14 & 258 & & & & & & & 9.6 & 648 & -70 & -10.0 & & & 60.5 & -5.9 & 13.9 \\
\hline B15 & 326 & & & & & & & 12.5 & 1263 & -64 & -9.1 & & & 78.0 & -9.3 & 6.2 \\
\hline B16 & 170 & & & & & & & & 365 & -58 & -8.3 & 29.93 & 1.1 & 37.6 & & 11.4 \\
\hline B17 & 235 & & & & & & & 11.2 & 254 & -62 & -8.8 & & & 53.2 & -11.2 & 9.0 \\
\hline B18 & 171 & & & & & & & 9.6 & 957 & -62 & -9.1 & & & 45.5 & -4.9 & 11.3 \\
\hline B19 & 96 & & & & & & & 15.9 & 197 & -74 & -10.8 & & 1.0 & 24.1 & & 4.8 \\
\hline B20 & 116 & & & & & & & 14.8 & 387 & -60 & -8.6 & & 0.8 & 32.8 & -8.0 & 10.5 \\
\hline B21 & 52 & & & & & & & 25.2 & 213 & -58 & -8.4 & 95.9 & 5.1 & 15.2 & & 3.0 \\
\hline B22 & 85 & & & & & & & 32.2 & 137 & -67 & -9.3 & & 0.8 & 24.6 & & 7.1 \\
\hline BF2 & 139 & & & & & & & 13.3 & 4539 & -60 & -8.8 & 16.8 & & 33.0 & -3.2 & 13.3 \\
\hline BF3 & 142 & & & & & & & 13.8 & 1157 & -61 & -9.0 & & & 31.8 & -3.3 & 13.3 \\
\hline BF4 & 117 & & & & & & & 11.5 & 33 & -82 & -11.5 & 7.7 & $<0.7$ & 28.9 & -6.8 & 7.8 \\
\hline BF6 & 149 & & & & & & & 13.5 & 144 & -60 & -8.7 & & $<0.3$ & 33.7 & -7.3 & 9.2 \\
\hline BF7 & 151 & & & & & & & 15.6 & 155 & -62 & -9.1 & & $<0.4$ & 35.0 & -6.4 & \\
\hline
\end{tabular}


Table A1. Water-quality data for precipitation, surface water, and groundwater in the middle San Pedro watershed collected from 2007 to February 2009.-Continued

\begin{tabular}{|c|c|c|c|c|c|c|c|c|c|c|c|c|c|c|c|c|c|}
\hline \multirow{2}{*}{ 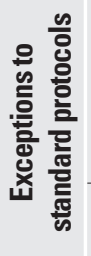 } & \multicolumn{2}{|l|}{ Station } & \multirow{2}{*}{$\begin{array}{c}\text { Sample } \\
\text { date }\end{array}$} & \multirow{2}{*}{ 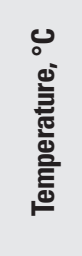 } & \multicolumn{2}{|c|}{ 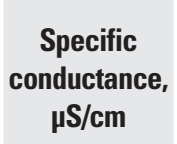 } & \multicolumn{2}{|c|}{$\mathrm{pH}$} & \multirow[t]{2}{*}{ 高 } & \multirow[t]{2}{*}{$\begin{array}{l}\text { E } \\
\text { ' } \\
\text { 言 } \\
\text { 元 }\end{array}$} & \multirow[t]{2}{*}{ 哥 } & \multirow[t]{2}{*}{$\begin{array}{l}\text { E } \\
\text { 总 } \\
\text { 芯 } \\
\text { ¿ }\end{array}$} & \multirow{2}{*}{$\begin{array}{r}\text { 은 } \\
\text { 흘 } \\
\text { mg/L }\end{array}$} & \multirow[t]{2}{*}{ 荧 } & \multirow[t]{2}{*}{$\begin{array}{l}\text { 㷰 } \\
\text { 密 }\end{array}$} & \multirow[t]{2}{*}{$\begin{array}{l}\text { 읗 } \\
\text { 은 }\end{array}$} & \multirow[t]{2}{*}{ 을 } \\
\hline & Number & Name & & & Field & Lab & Field & Lab & & & & & & & & & \\
\hline 5 & 315337110052901 & BF8 & $5 / 14 / 2008$ & 23.2 & 330 & & 8.0 & & 51.3 & 4.1 & 12.7 & 1.0 & 6.0 & 4.05 & 7.5 & 1.0 & 0.13 \\
\hline 1,4 & 315434110064501 & BF9 & $6 / 16 / 2008$ & 30.5 & 263 & & 7.8 & & 49.7 & 5.8 & 11.0 & 1.3 & 5.2 & 3.58 & 5.1 & 1.1 & 0.13 \\
\hline 4,5 & 315459110035201 & $\mathrm{BF} 10$ & $6 / 10 / 2008$ & 25.9 & 414 & & 8.6 & & 86.7 & 7.4 & 12.1 & 0.93 & 7.2 & 2.04 & 38.7 & 1.2 & 0.16 \\
\hline $1,5,6$ & 315504110030501 & BF11 & $11 / 15 / 2008$ & 15.1 & 180 & 484 & 7.2 & 7.8 & 88.7 & 7.0 & 13.6 & 0.89 & 7.0 & 1.91 & 38.1 & 1.3 & 0.12 \\
\hline 5 & 315541110042701 & BF12 & $4 / 26 / 2008$ & 25.0 & 377 & & 8.2 & & 51.0 & 9.5 & 15.9 & 1.3 & 10.4 & 7.64 & 13.2 & 1.5 & 0.12 \\
\hline 5 & 315650110233801 & BF13 & $6 / 10 / 2008$ & 27.1 & 314 & & 7.8 & & 17.0 & 7.3 & 53.4 & 2.5 & 11.0 & 9.19 & 6.7 & 1.0 & 0.19 \\
\hline 5 & 315724110215601 & BF14 & $6 / 9 / 2008$ & 27.2 & 309 & & 7.9 & & 49.2 & 7.4 & 17.4 & 2.0 & 8.6 & 6.50 & 8.8 & 0.71 & 0.14 \\
\hline 5,6 & 315745110133001 & BF15 & $11 / 5 / 2008$ & 22.2 & 103 & 267 & 7.3 & 8.1 & 26.5 & 4.7 & 25.4 & 1.8 & 3.6 & 2.75 & 5.1 & 1.7 & 0.04 \\
\hline 1,5 & 320327110222901 & BF16 & $2 / 2 / 2008$ & 20.3 & 318 & & 7.3 & & 25.9 & 2.9 & 16.7 & 2.5 & 6.6 & 3.84 & 11.0 & 0.29 & 0.11 \\
\hline 5 & 320656110182801 & BF17 & $1 / 10 / 2008$ & 20.4 & 977 & & 7.3 & & 88.5 & 19.3 & 50.4 & 4.4 & 6.4 & & 165 & 0.71 & 1.0 \\
\hline $1,4,5$ & 321216110183601 & BF18 & $6 / 19 / 2008$ & 24.1 & 1553 & & 7.2 & & 89.1 & 49.6 & 237 & 2.6 & 118 & 6.59 & 269 & 2.0 & 0.96 \\
\hline $3,4,5$ & 315005110122001 & $\mathrm{CBF} 2$ & $6 / 17 / 2008$ & 24.0 & 167 & & 8.6 & & 7.2 & $<0.1$ & 35.0 & 1.2 & 6.2 & 8.03 & 2.9 & 7.4 & 0.12 \\
\hline 1,5 & 315116110120601 & CBF3 & $11 / 22 / 2008$ & 19.1 & 191 & & 8.9 & & 2.5 & $<0.1$ & 30.3 & 1.1 & 4.0 & 2.64 & 4.4 & 1.6 & 0.05 \\
\hline 3,5 & 315116110121801 & CBF4 & $11 / 22 / 2008$ & 27.2 & 325 & & 6.9 & & 3.3 & $<0.1$ & 67.8 & 1.1 & 6.0 & 2.49 & 31.4 & 3.3 & 0.05 \\
\hline 5 & 315116110123401 & CBF5 & $11 / 22 / 2008$ & 25.6 & 223 & & 8.3 & & 3.5 & $<0.1$ & 46.9 & 1.2 & 4.5 & 2.60 & 5.4 & 5.8 & 0.06 \\
\hline 3,5 & 315203110131001 & CBF6 & $6 / 17 / 2008$ & 26.8 & 300 & & 8.0 & & 1.2 & $<0.1$ & 68.5 & 1.0 & 5.5 & 2.89 & 6.9 & 2.4 & 0.10 \\
\hline 5 & 315216110123001 & CBF7 & $6 / 19 / 2008$ & 26.9 & 198 & & 8.1 & & 17.5 & 0.39 & 27.3 & 1.8 & 3.8 & 2.77 & 4.0 & 1.8 & 0.10 \\
\hline 5 & 315235110124201 & CBF8 & $6 / 10 / 2008$ & 26.5 & 618 & & 7.0 & & 64.3 & 9.3 & 73.2 & 1.4 & 45.3 & 13.1 & 188 & 6.1 & 0.81 \\
\hline 5 & 315414110152301 & CBF9 & $5 / 29 / 2008$ & 23.9 & 388 & & 7.6 & & 41.7 & 12.4 & 36.4 & 2.5 & 4.7 & 2.29 & 10.8 & 2.8 & 0.11 \\
\hline 5,6 & 315426110124501 & CBF10 & $9 / 15 / 2007$ & 22.7 & 200 & & 7.7 & & 29.5 & 2.0 & 20.1 & 2.1 & 4.6 & 1.76 & 4.0 & 3.3 & 0.08 \\
\hline 5 & 315429110124501 & CBF11 & $6 / 19 / 2008$ & 24.6 & 250 & & 7.7 & & 34.2 & 3.2 & 21.9 & 1.8 & 4.9 & 2.60 & 5.0 & 1.1 & 0.12 \\
\hline 5 & 315454110124701 & CBF12 & $6 / 19 / 2008$ & 24.2 & 243 & & 7.7 & & 32.7 & 5.2 & 19.5 & 1.7 & 4.8 & 2.91 & 4.9 & 1.1 & 0.12 \\
\hline $2,3,5$ & 315456110151201 & CBF13 & $1 / 11 / 2009$ & 13.3 & 486 & & 7.7 & & 35.6 & 6.4 & 62.3 & 3.4 & 10.7 & 2.41 & 51.9 & 4.1 & 0.07 \\
\hline 5 & 315513110151101 & CBF14 & $5 / 29 / 2008$ & 23.2 & 677 & & 7.9 & & 48.5 & 9.1 & 115 & 3.9 & 29.8 & 2.50 & 168 & 4.4 & 0.16 \\
\hline 5 & 315525110141001 & CBF15 & $6 / 13 / 2008$ & 26.8 & 241 & & 8.4 & & 8.3 & 0.78 & 61.7 & 2.3 & 5.8 & 3.03 & 18.0 & 5.6 & 0.11 \\
\hline 5 & 315533110154901 & CBF16 & $5 / 30 / 2008$ & 27.0 & 1409 & & 7.2 & & 291 & 15.9 & 53.3 & 3.2 & 12.2 & 5.82 & 631 & 3.5 & 0.28 \\
\hline 2 & 315556110162301 & CBF17 & $5 / 30 / 2008$ & 27.6 & 422 & & 7.4 & & 38.5 & 10.6 & 41.6 & 2.4 & 4.8 & 2.43 & 2.4 & 3.8 & 0.09 \\
\hline 4,5 & 315611110173101 & CBF18 & $6 / 17 / 2008$ & 30.5 & 451 & & 8.0 & & 48.9 & 12.4 & 47.5 & 2.4 & 4.8 & 2.40 & 70.8 & 1.1 & 0.12 \\
\hline $1,4,5$ & 315757110144301 & CBF19 & $6 / 18 / 2008$ & 24.9 & 239 & & 8.2 & & 12.3 & 0.76 & 53.0 & 2.2 & 4.9 & 3.00 & 7.5 & 3.7 & 0.11 \\
\hline 5 & 315809110153801 & CBF20 & $6 / 18 / 2008$ & 32.4 & 429 & & 7.9 & & 24.2 & 4.1 & 69.6 & 3.3 & 5.4 & 2.72 & 21.2 & 3.6 & 0.11 \\
\hline 5 & 315942110162501 & CBF21 & $6 / 18 / 2008$ & 29.5 & 358 & & 7.7 & & 27.3 & 4.3 & 62.3 & 3.3 & 5.0 & 2.43 & 13.1 & 3.4 & 0.11 \\
\hline 4,5 & 315955110183101 & CBF22 & 2/10/2008 & 22.3 & 517 & & 7.5 & & 37.8 & 6.8 & 43.3 & 3.0 & 5.6 & 1.92 & 17.2 & 0.59 & 0.07 \\
\hline 5 & 320003110172501 & CBF23A & $6 / 18 / 2008$ & 29.8 & 680 & & 7.6 & & 34.8 & 8.8 & 44.5 & 2.5 & 5.4 & 2.84 & 13.7 & 0.46 & 0.46 \\
\hline 5 & 320024110175401 & CBF24 & $6 / 18 / 2008$ & 31.9 & 417 & 415 & 7.6 & 7.8 & 29.1 & 5.8 & 53.5 & 2.5 & 4.5 & 3.14 & 37.8 & 0.47 & 0.04 \\
\hline 5 & 320309110194201 & CBF25 & $1 / 9 / 2008$ & 25.8 & 633 & & 8.1 & & 17.1 & 1.8 & 84.3 & 2.2 & 5.1 & 2.71 & 69.3 & 0.70 & 0.09 \\
\hline 4,5 & 320412110210201 & CBF26 & $6 / 9 / 2008$ & 29.1 & 1367 & & 6.9 & & 126 & 3.0 & 260 & 2.0 & 12.4 & 5.65 & 735 & 2.6 & 0.30 \\
\hline
\end{tabular}


Table A1. Water-quality data for precipitation, surface water, and groundwater in the middle San Pedro watershed collected from 2007 to February 2009.-Continued

\begin{tabular}{|c|c|c|c|c|c|c|c|c|c|c|c|c|c|c|c|c|}
\hline \multirow[t]{2}{*}{$\begin{array}{l}\text { Station } \\
\text { name }\end{array}$} & $\begin{array}{l}\text { 离 } \\
\text { 言 } \\
\text { 产 }\end{array}$ & 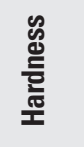 & 苇 & 㤩 & 호ํ & 호 & 豪 & \multirow{2}{*}{ 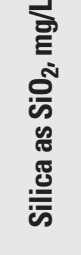 } & \multirow{2}{*}{ 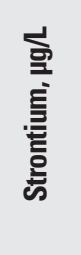 } & $\delta^{2} \mathbf{H}$ & $\delta^{18} 0$ & \multirow{2}{*}{ 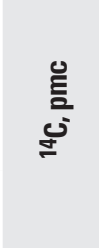 } & \multirow{2}{*}{ 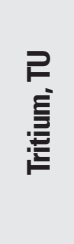 } & \multirow{2}{*}{$\begin{array}{l}\text { 预 } \\
\text { 言 }\end{array}$} & $\begin{array}{l}\text { U } \\
\text { U } \\
\frac{m}{0}\end{array}$ & 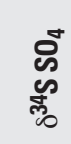 \\
\hline & as $\mathrm{CaCO}$ & $\mathrm{mg} / \mathrm{L}$ & & & $\mu g / L$ & & & & & \multicolumn{2}{|c|}{$\mathrm{H}_{2} \mathrm{O}(\%)$} & & & & \multicolumn{2}{|c|}{ Percent (\%) } \\
\hline BF8 & 151 & & & & & & & 15.5 & 155 & -62 & -8.9 & 78.8 & 0.9 & 33.0 & -7.5 & 7.9 \\
\hline BF9 & 155 & & & & & & & 14.3 & 168 & -62 & -9.2 & & 4.4 & & -8.3 & 8.9 \\
\hline BF10 & 200 & & & & & & & 14.2 & 234 & -60 & -8.7 & & 6.9 & 48.1 & -9.1 & 3.8 \\
\hline BF11 & 206 & 250 & & & 12 & 5 & 4 & 29.6 & 221 & -61 & -8.8 & 105.4 & 3.7 & 50.9 & -10.0 & 3.0 \\
\hline BF12 & 157 & & & & & & & 16.2 & 331 & -60 & -8.4 & & 1.3 & 35.0 & -3.8 & 9.5 \\
\hline $\mathrm{BF} 13$ & 148 & & & & & & & 20.7 & 405 & -67 & -9.2 & & & 34.6 & -5.8 & -8.4 \\
\hline BF14 & 158 & & & & & & & 15.3 & 163 & -57 & -8.1 & & & 35.2 & -7.9 & 11.9 \\
\hline BF15 & 133 & 86 & & & 38 & 34 & 56 & 27.8 & 815 & -56 & -8.1 & 33.7 & $<0.6$ & 29.3 & -7.5 & 9.5 \\
\hline BF16 & 87 & & & & & & & 13.6 & 355 & -55 & -8.0 & & 3.0 & 29.6 & -12.0 & 4.9 \\
\hline $\mathrm{BF} 17$ & 195 & & & & & & & 9.3 & 1260 & -52 & -7.7 & & 4.1 & 55.3 & & -8.2 \\
\hline $\mathrm{BF} 18$ & 401 & & & & & & & 20.5 & 1448 & -61 & -8.4 & & 3.6 & 95.4 & -9.0 & 9.3 \\
\hline CBF2 & 68 & & & & & & & 11.3 & 353 & -54 & -7.7 & 12.58 & & 12.1 & -8.9 & 9.0 \\
\hline CBF3 & 55 & & & & & & & 9.6 & & -49 & -7.4 & 20.3 & & 20.3 & -8.6 & 9.6 \\
\hline CBF4 & 108 & & & & & & & 9.7 & 316 & -55 & -8.2 & & & 21.4 & -7.0 & 9.1 \\
\hline CBF5 & 91 & & & & & & & 9.2 & 902 & -49 & -7.6 & & & 19.6 & -9.5 & 8.8 \\
\hline CBF6 & 141 & & & & & & & 9.5 & 213 & -57 & -8.1 & 10.5 & $<0.7$ & 24.6 & -5.8 & 10.1 \\
\hline CBF7 & 102 & & & & & & & 13.3 & 421 & -51 & -7.2 & 18.62 & & 22.4 & -8.5 & 10.0 \\
\hline CBF8 & 49 & & & & & & & 7.1 & 1802 & -54 & -7.8 & & $<0.6$ & 8.4 & -5.2 & 6.9 \\
\hline CBF9 & 199 & & & & & & & 15.6 & 1498 & -55 & -8.0 & 18.70 & 0.9 & 44.9 & -7.2 & 10.6 \\
\hline CBF10 & 107 & & & & & & & 14.5 & 571 & -56 & -8.1 & 1.2 & 0.8 & 28.3 & -7.7 & 7.8 \\
\hline CBF11 & 129 & & & & & & & 15.8 & 715 & -56 & -8.0 & & & 29.8 & -8.3 & 8.9 \\
\hline CBF12 & 132 & & & & & & & 17.5 & 633 & -56 & -7.9 & & & 29.3 & -8.2 & 9.4 \\
\hline CBF13 & 196 & & & & & & & 11.4 & 1375 & -60 & -8.9 & & $<0.6$ & 43.6 & -6.9 & 7.5 \\
\hline CBF14 & 174 & & & & & & & 11.3 & 1710 & -61 & -8.9 & 13.1 & 1.8 & 39.0 & -5.6 & 8.6 \\
\hline CBF15 & 120 & & & & & & & 9.4 & 939 & -53 & -7.8 & 21.68 & & 27.8 & -7.5 & 6.0 \\
\hline CBF16 & 147 & & & & & & & 16.1 & 5082 & -55 & -8.0 & 20.2 & 2.6 & 40.0 & -6.1 & 8.1 \\
\hline CBF17 & 184 & & & & & & & 17.9 & 1082 & -56 & -8.3 & & & 47.5 & -5.9 & 9.4 \\
\hline CBF18 & 181 & & & & & & & 17.4 & 1288 & -57 & -8.2 & 17.29 & & 42.2 & -5.5 & -8.2 \\
\hline CBF19 & 123 & & & & & & & 12.2 & 435 & -54 & -7.8 & 22.9 & & 27.8 & -7.8 & -10.7 \\
\hline CBF20 & 192 & & & & & & & 12.0 & 918 & -58 & -8.3 & & & 41.6 & -2.9 & 9.2 \\
\hline CBF21 & 190 & & & & & & & 13.6 & 894 & -57 & -8.4 & 17.1 & & 42.6 & -5.7 & 9.5 \\
\hline CBF22 & 183 & & & & & & & 17.8 & 913 & -59 & -8.6 & 27.3 & $<0.7$ & 42.7 & -6.4 & 9.3 \\
\hline CBF23A & 199 & & & & & & & 17.9 & 960 & -57 & -8.3 & 25.3 & & 43.3 & -6.2 & 8.1 \\
\hline CBF24 & 198 & 97 & E 1.0 & & 65 & 15 & 77 & 31.1 & 967 & -58 & -8.3 & & & 41.5 & -6.7 & 9.0 \\
\hline CBF25 & 132 & & & & & & & 13.0 & 794 & -64 & -9.0 & 8.0 & $<0.5$ & 32.0 & -6.0 & 10.3 \\
\hline CBF26 & 113 & & & & & & & 9.3 & 2880 & -75 & -10.4 & & & & -7.4 & 10.0 \\
\hline
\end{tabular}




\section{$74 \quad$ Hydrology of the Middle San Pedro Watershed, Southeastern Arizona}

Table A1. Water-quality data for precipitation, surface water, and groundwater in the middle San Pedro watershed collected from 2007 to February 2009.-Continued

\begin{tabular}{|c|c|c|c|c|c|c|c|c|c|c|c|c|c|c|c|c|}
\hline \multirow{2}{*}{ 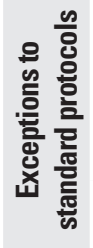 } & \multicolumn{2}{|l|}{ Station } & \multirow[t]{2}{*}{$\begin{array}{c}\text { Sample } \\
\text { date }\end{array}$} & \multirow{2}{*}{ 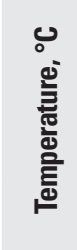 } & \multicolumn{2}{|c|}{$\begin{array}{c}\text { Specific } \\
\text { conductance, } \\
\text { } \mathrm{SS} / \mathrm{cm}\end{array}$} & $\mathrm{pH}$ & 恶 & \multirow[t]{2}{*}{$\begin{array}{l}\text { 言 } \\
\text { 言 } \\
\text { 焉 }\end{array}$} & \multirow[t]{2}{*}{ 害 } & \multirow[t]{2}{*}{ 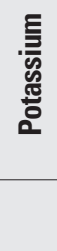 } & \multirow{2}{*}{ 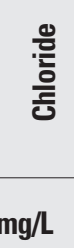 } & \multirow[t]{2}{*}{ 荧 } & \multirow[t]{2}{*}{ 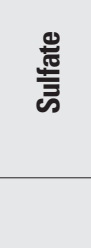 } & \multirow[t]{2}{*}{$\begin{array}{l}\text { 음 } \\
\text { 은 }\end{array}$} & \multirow[t]{2}{*}{ 总 } \\
\hline & Number & Name & & & Field & Lab & Field Lab & & & & & & & & & \\
\hline $1,2,5$ & 320420110211801 & $\mathrm{CBF} 27$ & $2 / 2 / 2008$ & 24.7 & 473 & & 8.3 & 10.3 & $<0.1$ & 48.6 & 2.2 & 4.8 & 2.21 & 31.1 & 0.72 & 0.06 \\
\hline 3,5 & 320439110205501 & CBF28 & $1 / 11 / 2009$ & 27.8 & 382 & & 8.1 & 9.7 & 0.28 & 82.9 & 2.0 & 5.3 & 3.03 & 42.8 & 0.73 & 0.07 \\
\hline 1,5 & 320446110205201 & CBF29 & $2 / 2 / 2008$ & 11.6 & 870 & & 8.5 & 40.8 & 1.3 & 176 & 1.6 & 12.1 & 5.84 & 360 & 3.4 & 0.31 \\
\hline 3,5 & 320543110183201 & CBF31 & $1 / 11 / 2009$ & 18.4 & 988 & & 7.4 & 95.8 & 24.5 & 102 & 2.7 & 40.3 & 15.0 & 273 & 2.8 & 0.01 \\
\hline $\begin{array}{c}1,3,4 \\
5\end{array}$ & 320642110181101 & CBF32 & $6 / 19 / 2008$ & 28.2 & 1120 & & 7.2 & 120 & 24.8 & 125 & 2.5 & 27.2 & 7.27 & 299 & 1.3 & 0.54 \\
\hline \multirow[t]{25}{*}{4,5} & 320708110182401 & CBF34 & $1 / 10 / 2008$ & 19.7 & 1174 & & 8.5 & 43.6 & 5.5 & 191 & 2.1 & 7.4 & 1.16 & 343 & 1.6 & 0.12 \\
\hline & 09471000 & R1A & $9 / 15 / 2007$ & 26.0 & 190 & & 8.0 & 56.3 & 10.1 & 21.9 & 3.8 & 6.6 & 0.66 & 22.7 & 1.0 & 0.09 \\
\hline & 09471000 & R1B & $10 / 22 / 2007$ & 15.8 & 513 & & 8.4 & 55.5 & 14.1 & 45.0 & 2.8 & 8.7 & 1.25 & 24.0 & 0.68 & 0.14 \\
\hline & 09471000 & $\mathrm{R} 1 \mathrm{C}$ & $8 / 1 / 2008$ & 28.2 & 292 & & 8.3 & 56.4 & 8.7 & 30.1 & 4.2 & 7.1 & 1.56 & 25.7 & 0.44 & 0.13 \\
\hline & 314323110113701 & $\mathrm{R} 2 \mathrm{~A}$ & $8 / 1 / 2008$ & 32.4 & 296 & & 8.5 & 51.1 & 7.7 & 27.2 & 4.8 & 6.5 & 1.70 & 23.2 & 0.42 & 0.13 \\
\hline & 314323110113701 & $\mathrm{R} 2 \mathrm{~B}$ & $11 / 2 / 2008$ & 20.5 & 375 & & 8.4 & 67.2 & 13.8 & 29.3 & 3.5 & 9.5 & 1.10 & 32.1 & 0.61 & 0.12 \\
\hline & 314323110113701 & $\mathrm{R} 2 \mathrm{C}$ & $1 / 12 / 2009$ & 12.2 & 507 & & 8.3 & 60.9 & 13.9 & 30.7 & 2.5 & 9.3 & 1.09 & 32.9 & 0.61 & 0.12 \\
\hline & 314738110130601 & $\mathrm{R} 3$ & $1 / 13 / 2009$ & 12.9 & 453 & & 8.3 & 59.6 & 13.1 & 31.1 & 2.7 & 9.2 & 1.09 & 35.1 & 0.59 & 0.11 \\
\hline & 315232110131001 & $\mathrm{R} 4 \mathrm{~A}$ & $2 / 10 / 2008$ & & & & 6.9 & 72.0 & 12.9 & 54.6 & 4.4 & 8.7 & & 66.2 & 1.3 & 0.12 \\
\hline & 315232110131001 & $\mathrm{R} 4 \mathrm{~B}$ & $8 / 1 / 2008$ & 34.3 & 212 & & 8.4 & 52.6 & 7.2 & 26.2 & 5.7 & 6.2 & 1.58 & 32.0 & 0.48 & 0.12 \\
\hline & 315232110131001 & $\mathrm{R} 4 \mathrm{C}$ & $12 / 13 / 2008$ & & & & 8.1 & 70.6 & 15.2 & 37.4 & 2.9 & 9.0 & 1.08 & 68.2 & 1.4 & 0.11 \\
\hline & 315232110131001 & R4D & $1 / 11 / 2009$ & 16.7 & 546 & & 7.5 & 69.4 & 13.8 & 36.4 & 3.5 & 9.5 & 1.12 & 60.1 & 1.2 & 0.11 \\
\hline & 315754110164301 & $\mathrm{R} 5 \mathrm{~A}$ & 9/7/2007 & & & & & 59.3 & 9.4 & 35.7 & 5.0 & 9.5 & 2.56 & 44.8 & 0.43 & 0.14 \\
\hline & 315754110164301 & $\mathrm{R} 5 \mathrm{~B}$ & $2 / 24 / 2008$ & & & & 8.2 & 66.1 & 15.3 & 79.2 & 3.7 & 11.8 & 7.71 & 103 & 1.8 & 0.19 \\
\hline & 315754110164301 & $\mathrm{R} 5 \mathrm{C}$ & $8 / 2 / 2008$ & 33.1 & 240 & & 8.5 & 53.8 & 7.7 & 26.4 & 5.9 & 6.3 & 3.16 & 37.5 & 0.54 & 0.09 \\
\hline & 09471840 & R6A & $8 / 15 / 2008$ & & & & 8.2 & 40.7 & 6.6 & 23.0 & 3.7 & 6.0 & 3.94 & 35.8 & 0.55 & 0.11 \\
\hline & 09471840 & R6B & $9 / 11 / 2008$ & & & & & 30.1 & 5.9 & 44.6 & 4.1 & & & & & \\
\hline & 09471820 & R7 & $8 / 15 / 2008$ & & & & 7.8 & 39.4 & 6.5 & 21.7 & 2.7 & 5.4 & 3.86 & 34.5 & 0.69 & 0.10 \\
\hline & 322500110433201 & P1A & $4 / 22 / 2008$ & & & & & & & & & & & & & \\
\hline & 322500110433201 & P1B & $12 / 1 / 2008$ & & & & & & & & & & & & & \\
\hline & 315230110130701 & P2A & $5 / 15 / 2008$ & & & & & & & & & & & & & \\
\hline & 315230110130701 & P2B & $7 / 15 / 2009$ & & & & & & & & & & & & & \\
\hline & 315939110002101 & P3A & $5 / 15 / 2008$ & & & & & & & & & & & & & \\
\hline & 315939110002101 & P3B & $10 / 11 / 2008$ & & & & & & & & & & & & & \\
\hline & 314944110233201 & P4 & $5 / 15 / 2008$ & & & & & & & & & & & & & \\
\hline
\end{tabular}

Exceptions to standard protocols

1. Sample collected after pressure tank

2. Sample collected after water piped away from well head

3. Sample collected in bucket

4. Sample collected before three well volumes were purged

5. Sample collected before stabilization of field parameters

6. Field parameter meters not calibrated 
Table A1. Water-quality data for precipitation, surface water, and groundwater in the middle San Pedro watershed collected from 2007 to February 2009.-Continued

\begin{tabular}{|c|c|c|c|c|c|c|c|c|c|c|c|c|c|c|c|}
\hline \multirow{2}{*}{$\begin{array}{l}\text { Station } \\
\text { name }\end{array}$} & \multirow{2}{*}{ 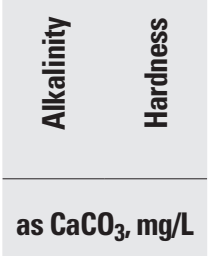 } & \multirow[t]{2}{*}{ 㤩 } & \multirow[t]{2}{*}{ 志 } & \multirow{2}{*}{$\begin{array}{c}\text { 흘 } \\
\mu g / L\end{array}$} & \multirow[t]{2}{*}{ 흐 } & \multirow[t]{2}{*}{ 䓃 } & \multirow{2}{*}{ 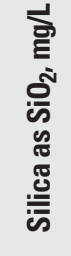 } & \multirow{2}{*}{ 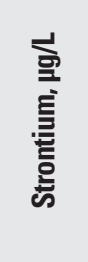 } & $\delta^{2} \mathrm{H}$ & $\delta^{18} 0$ & \multirow{2}{*}{ 兰 } & \multirow{2}{*}{ 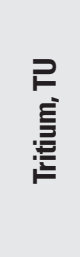 } & \multirow{2}{*}{ 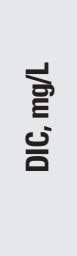 } & \multirow{2}{*}{\multicolumn{2}{|c|}{ 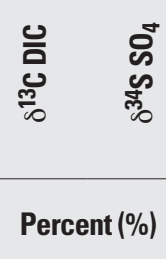 }} \\
\hline & & & & & & & & & \multicolumn{2}{|c|}{$\mathrm{H}_{2} \mathrm{O}(\% 0)$} & & & & & \\
\hline CBF27 & 86 & & & & & & 9.2 & 351 & -70 & -10.2 & & 0.9 & & -5.9 & 10.7 \\
\hline CBF28 & 160 & & & & & & 9.4 & 240 & -62 & -9.1 & & $<0.5$ & 34.8 & -5.8 & 10.6 \\
\hline CBF29 & 25 & & & & & & 10.6 & 983 & -85 & -11.8 & 3.6 & 0.8 & & -7.3 & 10.1 \\
\hline CBF31 & 262 & & & & & & 11.6 & 1362 & -50 & -7.4 & & & 63.0 & -9.3 & 5.9 \\
\hline CBF32 & 260 & & & & & & 14.1 & 1634 & -54 & -7.5 & 95.89 & 4.9 & 60.2 & -9.2 & 5.1 \\
\hline CBF34 & 124 & & & & & & 7.7 & 1437 & -65 & -9.4 & & & 31.4 & & 9.8 \\
\hline $\mathrm{R} 1 \mathrm{~A}$ & 186 & & & & & & 10.5 & 431 & -57 & -8.1 & & & 45.8 & -8.9 & \\
\hline R1B & 240 & & & & & & 12.3 & 551 & -58 & -7.9 & & & 60.7 & & 6.0 \\
\hline $\mathrm{R} 1 \mathrm{C}$ & 203 & & & & & & 10.7 & 372 & -58 & -8.0 & & & & & \\
\hline $\mathrm{R} 2 \mathrm{~A}$ & 179 & & & & & & 9.5 & 323 & -56 & -7.8 & & & & & \\
\hline R2B & 247 & & & & & & 10.6 & 499 & -55 & -7.6 & & & 53.2 & & 6.9 \\
\hline $\mathrm{R} 2 \mathrm{C}$ & 239 & & & & & & 10.5 & 451 & -55 & -7.7 & & & 54.4 & & \\
\hline $\mathrm{R} 3$ & 243 & & & & & & 10.0 & 511 & & & & & 53.9 & -6.3 & \\
\hline $\mathrm{R} 4 \mathrm{~A}$ & 242 & & & & & & 12.2 & 1190 & -52 & -7.1 & & & 55.6 & -8.3 & 4.8 \\
\hline R4B & 176 & & & & & & 9.1 & 429 & -55 & -7.6 & & & & & \\
\hline $\mathrm{R} 4 \mathrm{C}$ & 242 & & & & & & 11.6 & 1242 & -52 & -7.3 & & & 57.1 & -8.2 & \\
\hline R4D & 250 & & & & & & 11.4 & 1039 & -52 & -7.3 & & & & & \\
\hline $\mathrm{R} 5 \mathrm{~A}$ & 191 & & & & & & 8.1 & 882 & & & & & & & \\
\hline $\mathrm{R} 5 \mathrm{~B}$ & 239 & & & & & & 11.2 & 1429 & -41 & -6.2 & & & & & \\
\hline $\mathrm{R} 5 \mathrm{C}$ & 181 & & & & & & 9.0 & 524 & -54 & -7.1 & & & & & \\
\hline R6A & 118 & & & & & & 7.0 & 462 & -42 & -6.1 & & & & & \\
\hline R6B & & & & & & & 6.2 & 513 & -31 & -4.9 & & & & & \\
\hline R7 & 116 & & & & & & 6.6 & 454 & -35 & -5.2 & & & & & \\
\hline P1A & & & & & & & & & -100 & -15.0 & & & & & \\
\hline P1B & & & & & & & & & -60 & -9.4 & & & & & \\
\hline $\mathrm{P} 2 \mathrm{~A}$ & & & & & & & & & -52 & -7.6 & & & & & \\
\hline P2B & & & & & & & & & -55 & -7.9 & & & & & \\
\hline P3A & & & & & & & & & -75 & -10.6 & & & & & \\
\hline P3B & & & & & & & & & -56 & -8.2 & & & & & \\
\hline P4 & & & & & & & & & -75 & -10.5 & & & & & \\
\hline
\end{tabular}


Table A2. Water-quality data for groundwater in middle San Pedro Watershed collected in August and December 2009.

[All major and trace elements are dissolved. ${ }^{\circ} \mathrm{C}$, degrees Celsius; mmHg, millimeters of mercury; $\mu \mathrm{S} / \mathrm{cm}$, microsiemens per centimeter; mg/L, milligrams per liter; NTU, nephlometric turbidity units; N, nitrogen; P, phosphorus]

\begin{tabular}{|c|c|c|c|c|c|c|c|c|c|c|c|}
\hline \multirow[t]{2}{*}{ Station number } & \multirow[t]{2}{*}{$\begin{array}{l}\text { Station } \\
\text { Name }\end{array}$} & \multirow[t]{2}{*}{$\begin{array}{c}\text { Sample } \\
\text { Date }\end{array}$} & \multirow[t]{2}{*}{$\begin{array}{c}\text { Temperature, } \\
{ }^{\circ} \mathrm{C}\end{array}$} & \multicolumn{2}{|c|}{$\begin{array}{c}\text { Specific } \\
\text { conductance, } \\
\text { in } \mu \mathrm{S} / \mathrm{cm}\end{array}$} & \multicolumn{2}{|c|}{ pH } & \multirow[t]{2}{*}{$\begin{array}{c}\text { Dissolved } \\
\text { oxygen, } \\
\text { mg/L }\end{array}$} & \multirow[t]{2}{*}{$\begin{array}{c}\text { Barometric } \\
\text { pressure, } \\
\text { mmHg }\end{array}$} & \multirow[t]{2}{*}{$\begin{array}{c}\text { Turbidity, } \\
\text { NTU }\end{array}$} & \multirow{2}{*}{$\begin{array}{c}\text { Dissolved } \\
\text { solids, } \\
\text { dried at } 180^{\circ} \mathrm{C} \text {, } \\
\mathrm{mg} / \mathrm{L}\end{array}$} \\
\hline & & & & Field & Lab & Field & Lab & & & & \\
\hline 315712110205401 & $(\mathrm{BF}, \mathrm{B}) 1 \mathrm{~B}$ & $8 / 7 / 2009$ & 25.8 & 369 & 374 & 7.5 & 7.6 & 5.8 & 662 & 0.2 & 234 \\
\hline 314441110311501 & B1 & $12 / 16 / 2009$ & 19.9 & 484 & 503 & 7.2 & 7.6 & 4.7 & 646 & 3.1 & 295 \\
\hline 315520110130501 & B6 & $8 / 5 / 2009$ & 23.5 & 267 & 270 & 8.1 & 8.2 & 5.8 & 670 & 22 & 173 \\
\hline 314507110050101 & BF5 & $8 / 5 / 2009$ & 25.8 & 314 & 330 & 7.7 & 7.8 & 7.6 & 654 & 0.7 & 211 \\
\hline 314953110124201 & CBF1 & $8 / 4 / 2009$ & 20.3 & 594 & 605 & 7.4 & 7.5 & 0.8 & 667 & 0.3 & 385 \\
\hline 320003110172501 & CBF23B & $8 / 12 / 2009$ & 29.9 & 384 & 389 & 7.5 & 7.7 & 4.9 & 676 & 0.3 & 245 \\
\hline 320457110204101 & $\mathrm{CBF} 30$ & $8 / 6 / 2009$ & 27.6 & 488 & 505 & 8.4 & 8.5 & 4.6 & 676 & 0.5 & 339 \\
\hline
\end{tabular}

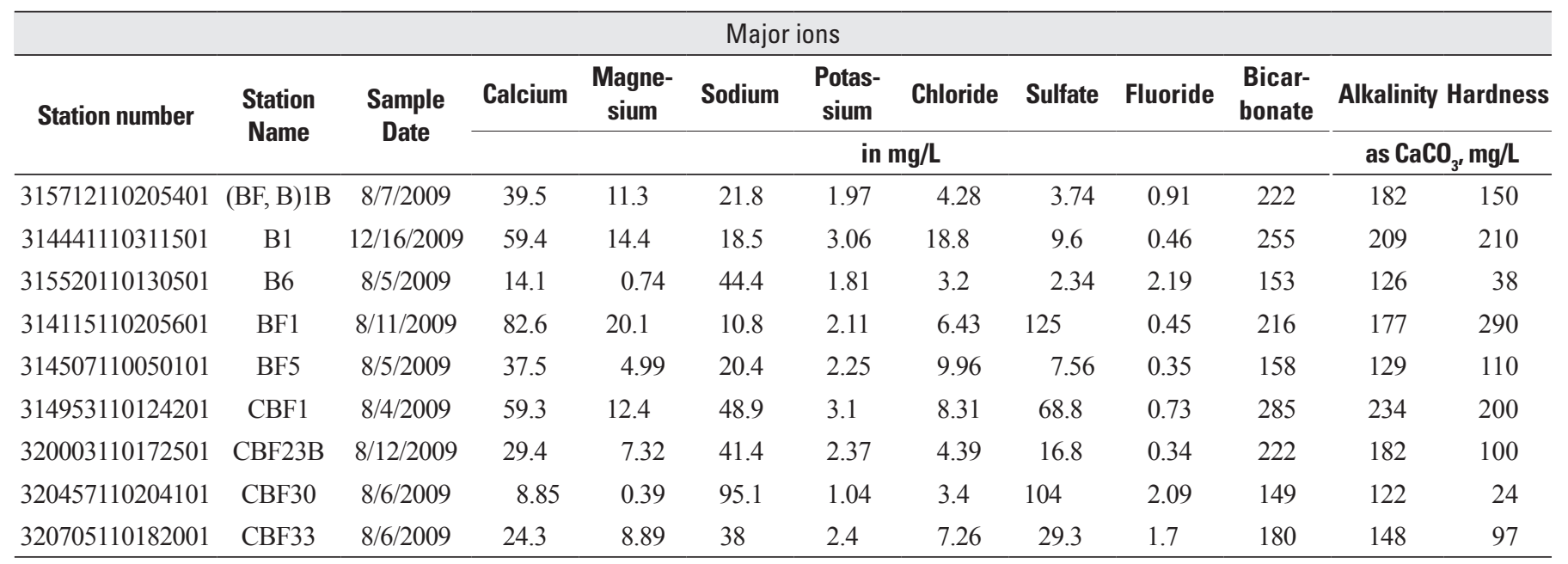

\begin{tabular}{|c|c|c|c|c|c|c|c|c|c|}
\hline \multicolumn{10}{|c|}{ Nutrients } \\
\hline \multirow[t]{2}{*}{ Station number } & \multirow{2}{*}{$\begin{array}{l}\text { Station } \\
\text { Name }\end{array}$} & \multirow{2}{*}{$\begin{array}{c}\text { Sample } \\
\text { Date }\end{array}$} & Ammonia & Nitrite & \multirow{2}{*}{$\begin{array}{l}\text { Nitrate plus } \\
\text { nitrite, } \mathrm{mg} / \mathrm{L} \\
\text { as } \mathrm{N}\end{array}$} & $\begin{array}{c}\text { Total } \\
\text { nitrogen }\end{array}$ & Orthophosphate & Phosphorus & Orthophosphate \\
\hline & & & \multicolumn{2}{|c|}{$\mathrm{mg} / \mathrm{L}$ as $\mathrm{N}$} & & \multicolumn{2}{|r|}{$\mathrm{mg} / \mathrm{L}$} & \multicolumn{2}{|c|}{$\mathrm{mg} / \mathrm{L}$ as $P$} \\
\hline 315712110205401 & $(\mathrm{BF}, \mathrm{B}) 1 \mathrm{~B}$ & $8 / 7 / 2009$ & $<0.020$ & $<0.002$ & 0.78 & 0.74 & 0.039 & $<0.006$ & 0.013 \\
\hline 314441110311501 & B1 & $12 / 16 / 2009$ & $<0.020$ & $<0.002$ & 2.5 & 2.46 & 0.051 & 0.008 & 0.017 \\
\hline 314507110050101 & BF5 & $8 / 5 / 2009$ & $<0.020$ & $<0.002$ & 3.91 & 3.85 & 0.042 & E 0.003 & 0.014 \\
\hline 314953110124201 & CBF1 & $8 / 4 / 2009$ & E 0.010 & $<0.002$ & 0.18 & 0.2 & 0.109 & 0.03 & 0.036 \\
\hline 320003110172501 & CBF23B & $8 / 12 / 2009$ & $<0.020$ & $<0.002$ & 0.5 & 0.51 & 0.05 & $<0.006$ & 0.016 \\
\hline 320457110204101 & CBF30 & $8 / 6 / 2009$ & $<0.020$ & $<0.002$ & 0.45 & 0.47 & 0.037 & $<0.006$ & 0.012 \\
\hline
\end{tabular}


Table A2. Water-quality data for groundwater in middle San Pedro Watershed collected in August and December 2009.—Continued

\begin{tabular}{|c|c|c|c|c|c|c|c|c|c|c|c|c|}
\hline \multicolumn{13}{|c|}{ Trace elements } \\
\hline \multirow{2}{*}{ Station number } & \multirow{2}{*}{$\begin{array}{l}\text { Station } \\
\text { Name }\end{array}$} & \multirow{2}{*}{$\begin{array}{l}\text { Sample } \\
\text { Date }\end{array}$} & Aluminum & Antimony & Arsenic & Barium & Beryllium & Bromide & Cadmium & Chromium & Cobalt & Copper \\
\hline & & & \multicolumn{10}{|c|}{$\mu \mathrm{g} / \mathrm{L}$} \\
\hline 315712110205401 & $(\mathrm{BF}, \mathrm{B}) 1 \mathrm{~B}$ & $8 / 7 / 2009$ & $<4.0$ & E 0.03 & 3.1 & 132 & E 0.01 & 0.05 & $<0.02$ & 0.5 & 0.04 & $<1.0$ \\
\hline 314441110311501 & B1 & $12 / 16 / 2009$ & $<3.4$ & $<0.05$ & 1.4 & 348 & $<0.01$ & 0.2 & E 0.01 & 0.91 & 0.27 & $<1.0$ \\
\hline 315520110130501 & B6 & $8 / 5 / 2009$ & $<4.0$ & E 0.03 & 0.45 & 79 & $<0.02$ & 0.04 & $<0.02$ & 2.4 & 0.02 & $<1.0$ \\
\hline 314115110205601 & $\mathrm{BF} 1$ & 8/11/2009 & $<4.0$ & 0.06 & 3.5 & 28 & $<0.02$ & 0.07 & $<0.02$ & 0.46 & 0.14 & $<1.0$ \\
\hline 314507110050101 & BF5 & $8 / 5 / 2009$ & $<4.0$ & 0.08 & 9.3 & 23 & $<0.02$ & 0.16 & $<0.02$ & 0.24 & 0.09 & $<1.0$ \\
\hline 314953110124201 & $\mathrm{CBF} 1$ & $8 / 4 / 2009$ & $<4.0$ & 0.08 & 7.4 & 117 & $<0.02$ & 0.09 & E 0.01 & 0.44 & 0.07 & $<1.0$ \\
\hline 320003110172501 & CBF23B & 8/12/2009 & 6.8 & 0.04 & 23 & 350 & Е 0.01 & 0.04 & $<0.02$ & 0.94 & 0.05 & $<1.0$ \\
\hline 320457110204101 & CBF30 & $8 / 6 / 2009$ & E 3.4 & 0.11 & 34 & 15 & $<0.02$ & 0.04 & E 0.02 & 6.1 & E 0.01 & $<1.0$ \\
\hline 320705110182001 & $\mathrm{CBF} 33$ & 8/6/2009 & E 3.3 & Е 0.04 & 4.4 & 30 & $<0.02$ & 0.06 & 0.02 & 2.5 & 0.03 & $<1.0$ \\
\hline
\end{tabular}

\begin{tabular}{|c|c|c|c|c|c|c|c|c|c|c|c|c|}
\hline \multicolumn{13}{|c|}{ Trace elements } \\
\hline \multirow{2}{*}{ Station number } & \multirow{2}{*}{$\begin{array}{l}\text { Station } \\
\text { Name }\end{array}$} & \multirow{2}{*}{$\begin{array}{c}\text { Sample } \\
\text { Date }\end{array}$} & Iron & Lead & Manganese & Molybdenum & Nickel & Selenium & Silver & Uranium & Zinc & \multirow{2}{*}{$\begin{array}{c}\text { Silica } \\
\text { as } \mathrm{SiO}_{2^{\prime}} \\
\mathrm{mg} / \mathrm{L}\end{array}$} \\
\hline & & & \multicolumn{9}{|c|}{$\mu g / L$} & \\
\hline 315712110205401 & $(\mathrm{BF}, \mathrm{B}) 1 \mathrm{~B}$ & $8 / 7 / 2009$ & $<4$ & 0.23 & $<0.2$ & 1.3 & 0.16 & 0.36 & $<0.008$ & 4.78 & E 1.1 & 34.3 \\
\hline 314441110311501 & B1 & $12 / 16 / 2009$ & 9 & 0.07 & 1.2 & 0.9 & 2.3 & 0.56 & $<0.010$ & 1.19 & 29.8 & 24.6 \\
\hline 315520110130501 & B6 & $8 / 5 / 2009$ & 5 & 0.1 & 0.8 & 1.6 & 0.27 & 0.44 & $<0.008$ & 14.2 & 17.1 & 29.5 \\
\hline 314115110205601 & $\mathrm{BF} 1$ & $8 / 11 / 2009$ & $<4$ & 0.36 & $<0.2$ & 1.6 & 0.59 & 1.3 & $<0.008$ & 1.74 & 4.8 & 25.7 \\
\hline 314507110050101 & BF5 & $8 / 5 / 2009$ & $<4$ & E 0.04 & $<0.2$ & 1.9 & 0.16 & 0.82 & $<0.008$ & 2.94 & $<2.0$ & 31.1 \\
\hline 314953110124201 & CBF1 & $8 / 4 / 2009$ & $<4$ & 0.32 & E 0.1 & 2.4 & 0.34 & 0.33 & $<0.008$ & 8.22 & 2 & 24.8 \\
\hline 320003110172501 & CBF23B & 8/12/2009 & $<4$ & 0.62 & E 0.1 & 3.9 & 0.21 & 0.61 & $<0.008$ & 4.01 & 20.3 & 32.9 \\
\hline 320457110204101 & CBF30 & $8 / 6 / 2009$ & 6 & $<0.06$ & 0.2 & 6.2 & Е 0.07 & 0.49 & $<0.008$ & 42.1 & 8.8 & 19.5 \\
\hline 320705110182001 & CBF33 & $8 / 6 / 2009$ & 6 & 0.4 & 0.5 & 8.4 & E 0.11 & 0.54 & $<0.008$ & 5.86 & 21.9 & 26.5 \\
\hline
\end{tabular}

Menlo Park Publishing Service Center, California Manuscript approved for publication April 12, 2013 Edited by Larry B. Slack and Claire M. Landowski Design and layout by Jeanne S. DiLeo 
웅

蛋

종

웋

क्ञ

흠

胥

훅

赵

产

is

产

产

$\stackrel{3}{3}$

i

$\stackrel{1}{\circ}$

言

इ

备.

ㅎ․․

के

꾱

7

음

c) 